EsZTER ÓTOTT-KovÁCS

\title{
The syntax of non-finite clauses in Kazakh
}

$\mathrm{PhD}$ dissertation

Supervisors:

DR. ÉVA KINCSES NAGY

PROF. DR. ANDRÁS RÓNA-TAS

University of Szeged

Graduate School in Linguistics

Altaic Studies Programme

Szeged, 2015. 


\section{Contents}

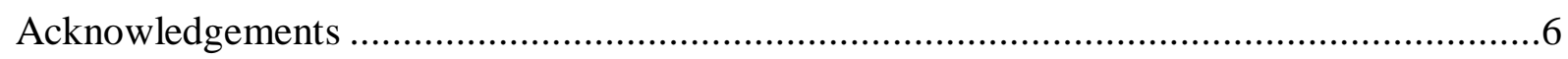

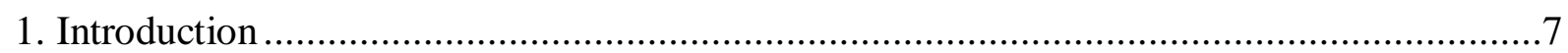

1.1. Short history of research and the aim of the dissertation ..........................................

1.2 Sources and transcription of the Kazakh examples ................................................

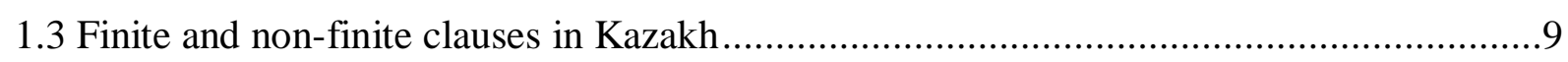

1.4 A short description of Kazakh non-finite clauses....................................................... 14

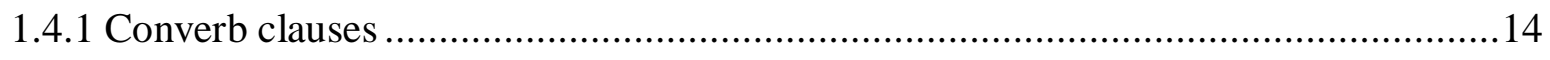

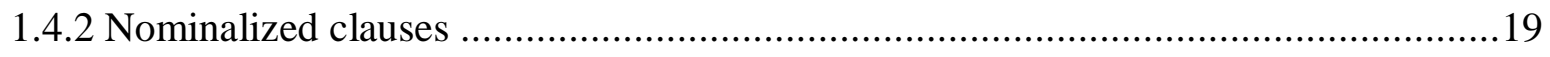

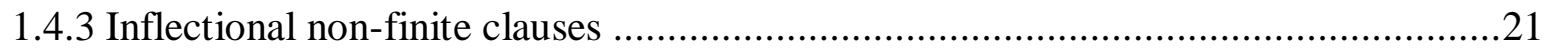

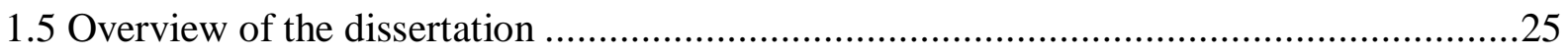

2. Syntactic position of non-finite heads and subjects of non-finite clauses .........................26

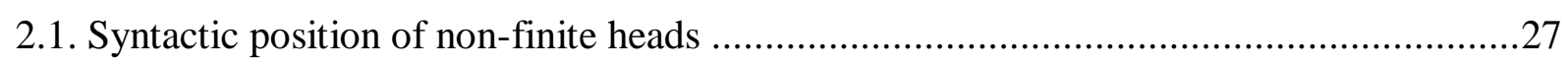

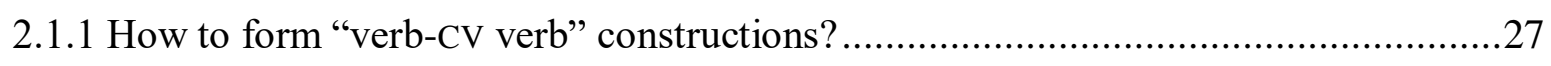

2.1.2 Converb clauses and "verb-CV verb" constructions........................................... 31

2.1.3 Order of inflecting verbs (in "verb-CV verb" constructions) ...................................33

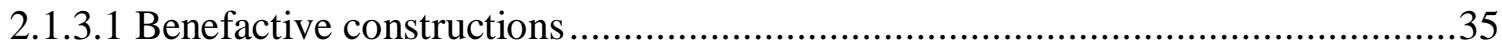

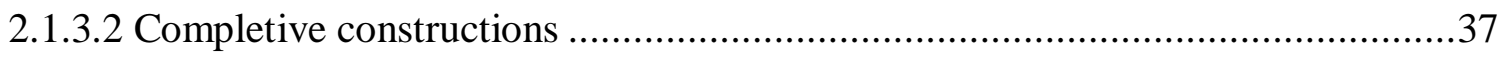

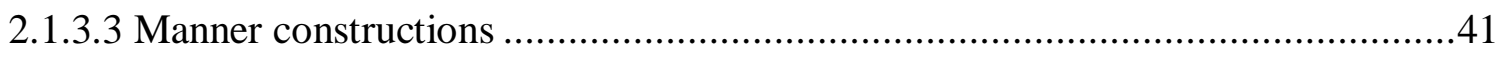

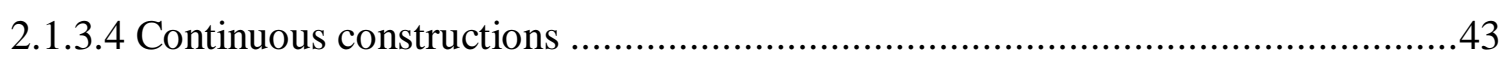

2.1.3.5 Notes on complex "verb-CV verb" constructions ...........................................44

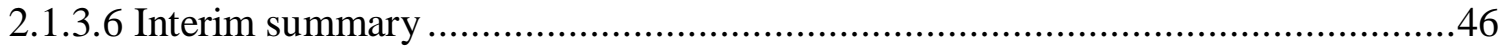

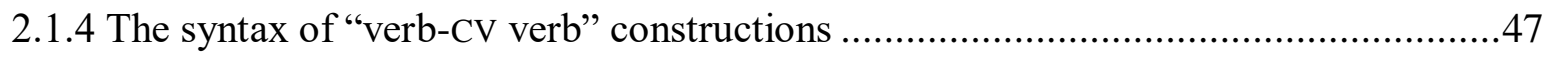

2.1.4.1 Inflecting verbs are light verbs ............................................................. 47

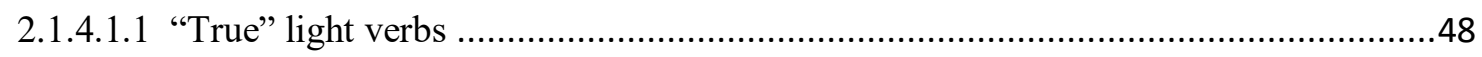

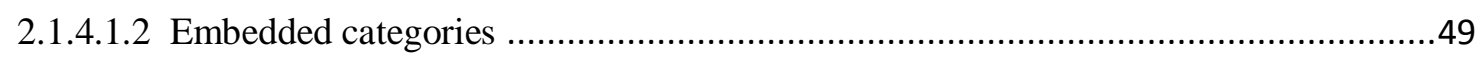

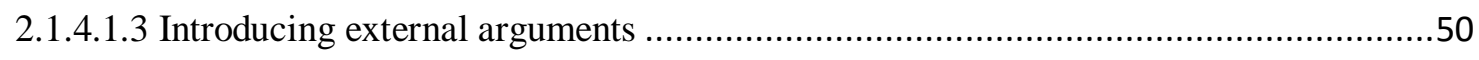

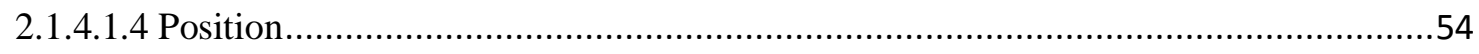

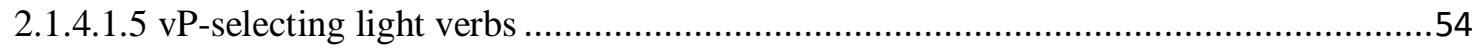

2.1.4.2 "Converb morphemes" in "verb-CV verb" constructions ................................56

2.1.5 Verbal functional categories and their order in Kazakh.......................................57

2.3.5.1 Non-finite heads embedding high light verbs ............................................57 


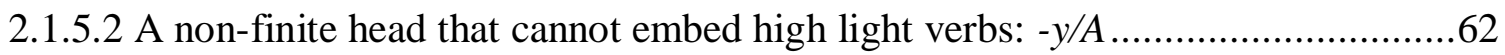

2.1.5.2.1 Notes on complex converb morphemes ................................................................64

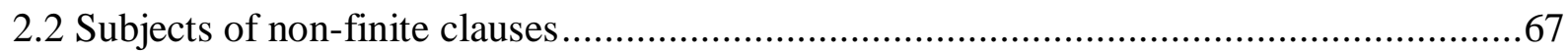

2.2.1 Subjects and subject cases in Kazakh - An overview ........................................68

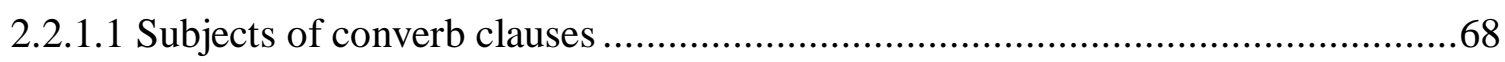

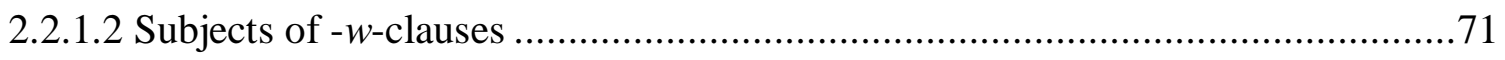

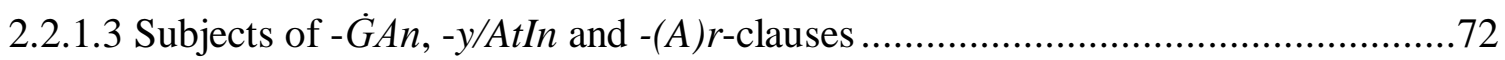

2.2.2 Correlation between the position of non-finite heads and independent subjects ........74

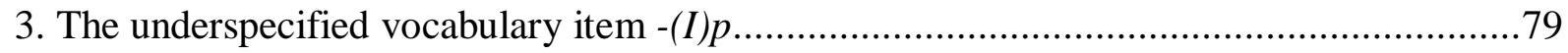

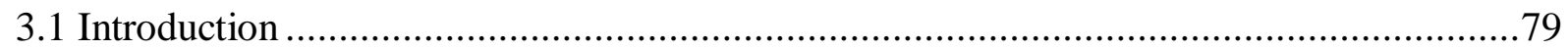

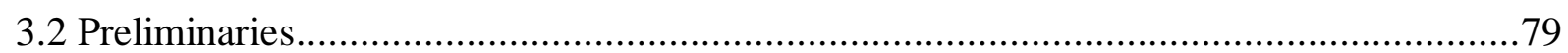

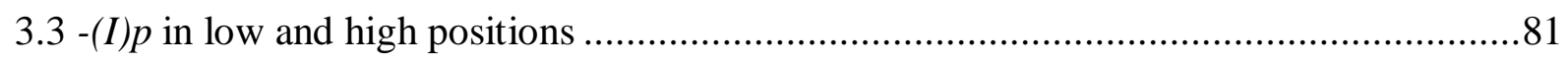

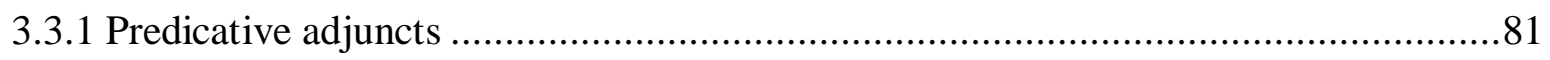

3.3.1.1 The $-(I) p$-head (in predicative adjuncts) embeds VoiceP .................................83

3.3.1.2 Predicative adjunct $-(I) p$-clauses adjoined to the matrix VoiceP.........................85

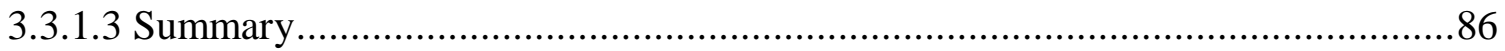

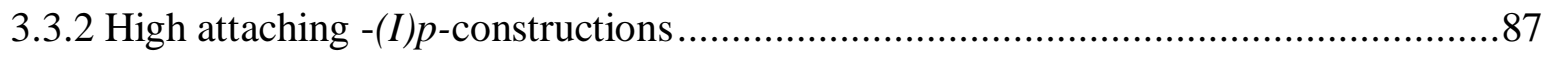

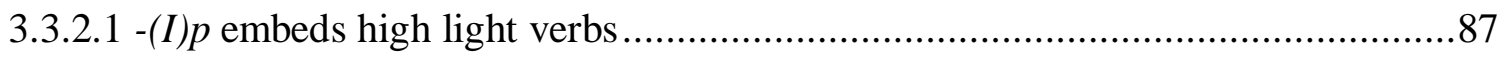

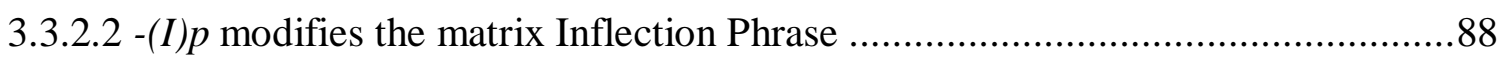

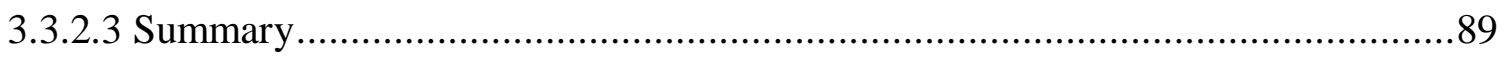

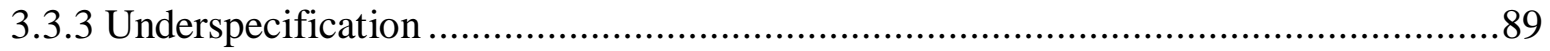

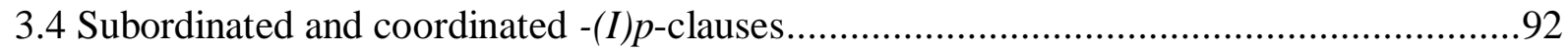

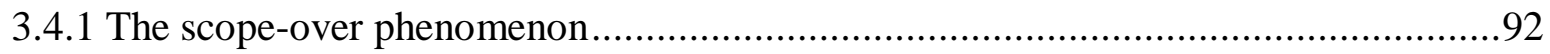

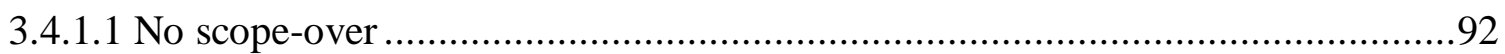

3.4.1.2 Scope-over in coordinated clauses ....................................................... 93

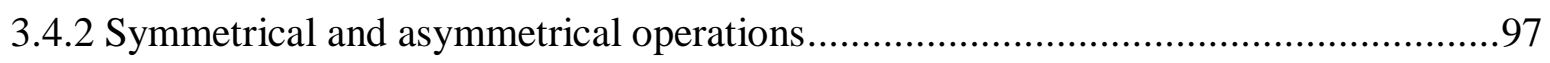

3.4.2.1 Asymmetrical application of certain syntactic operations ..............................97

3.4.2.1.1 Asymmetrical operations are grammatical with certain $-(I) p$-clauses.......................99

3.4.2.1.2 Asymmetrical operations are not grammatical with certain $-(I) p$-clauses................100

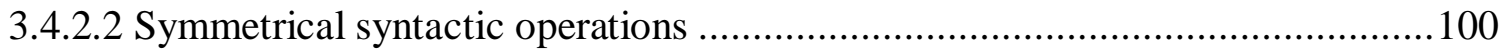

3.4.2.2.1 Symmetrical questions are grammatical in certain $-(I) p$-clauses ............................102

3.4.2.2.2 Symmetrical questions are ungrammatical in certain $-(I) p$-clauses .........................103

3.4.3 Cataphoras in subordinated and coordinated clauses ........................................... 103 


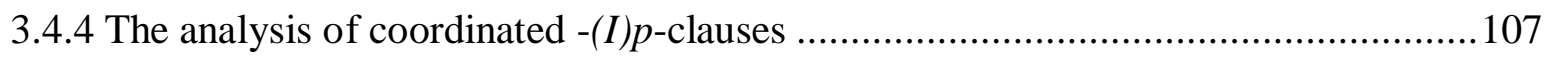

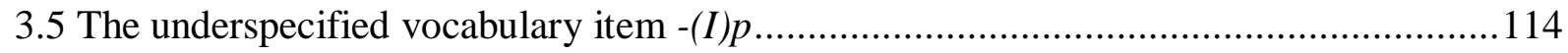

4. Kazakh nominalized and non-nominalized non-finite clauses.......................................117

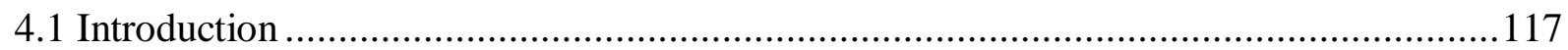

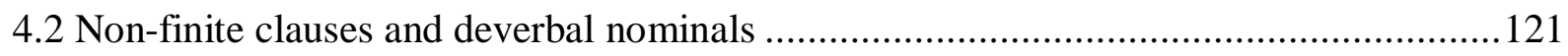

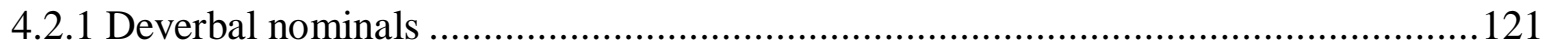

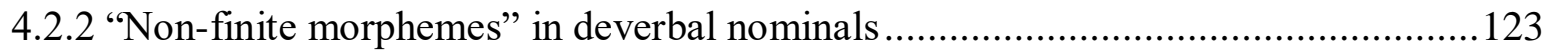

4.3 Non-finite clauses in three syntactic positions: The dataset ..................................... 125

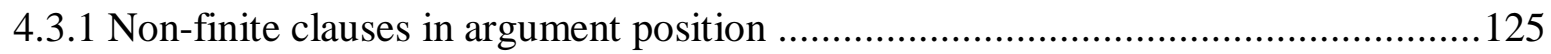

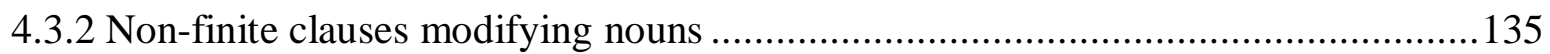

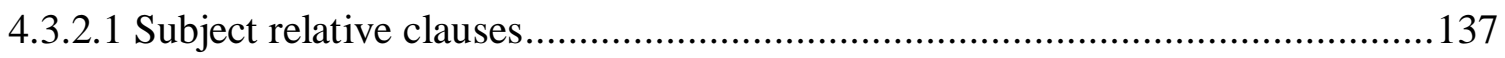

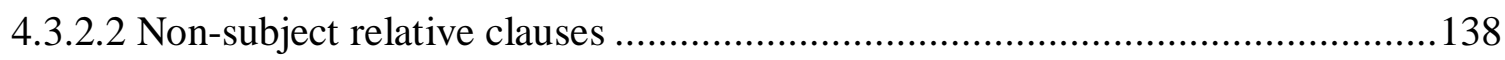

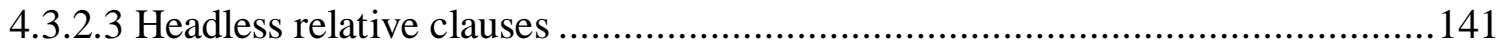

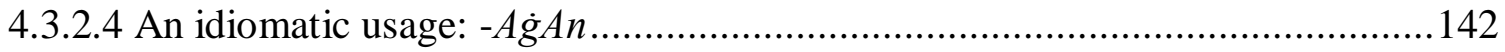

4.3.3 Non-finite complement clauses of semantic cases or postpositions .......................143

4.3.3.1 -w, $-(I) s$ and $-M A q$-headed non-argument clauses ........................................ 146

4.3.3.2 -(I)s and -MAq-headed (non-argument) clauses ........................................... 149

4.3.3.3 - $\dot{G} A n$ and -y/AtIn-headed complement clauses of semantic cases and

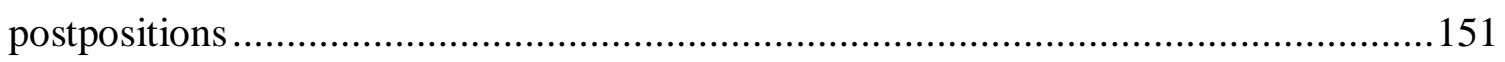

4.3.3.4 -(A)r-headed complement clauses of semantic cases and postpositions ............155

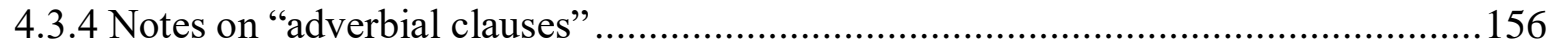

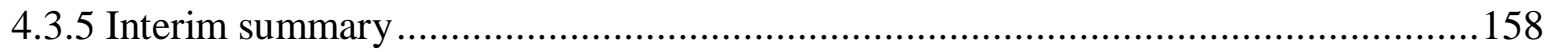

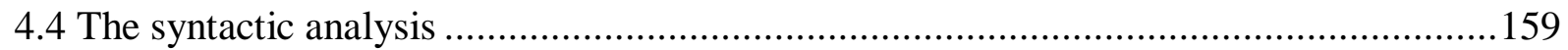

4.4.1 Kornfilt's (2001a, 2003, 2006, 2007) approach .............................................. 159

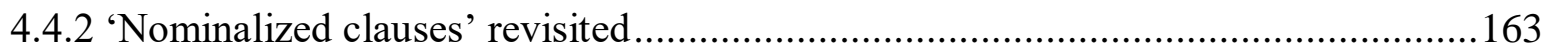

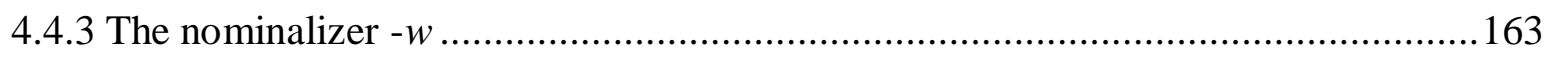

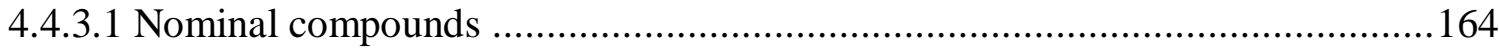

4.4.3.2 Suffixes attached to non-finite heads ........................................................ 168

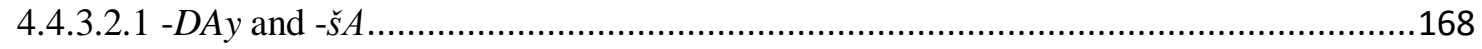

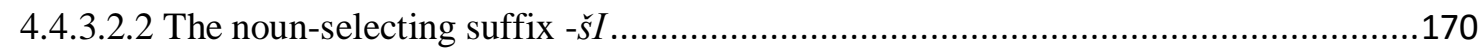

4.4.3.2.3 A short note on semantic cases and postpositions .................................................173

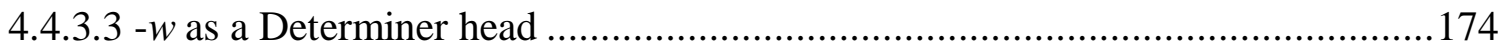

4.4.4 Non-nominalized and nominalized $-\dot{G} A n$-type of clauses................................. 179 


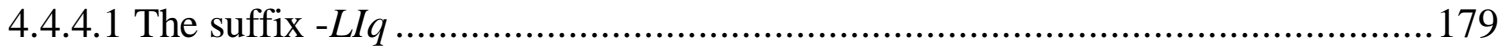

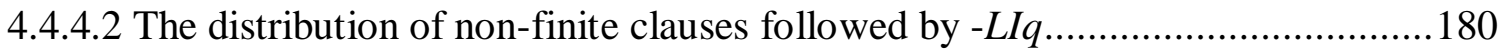

4.4.4.2.1 Non-finite clauses followed by $-L I q$ in argument position .....................................181

4.4.4.2.2 Complement clauses of semantic cases and postpositions followed by $-L I q$...........183

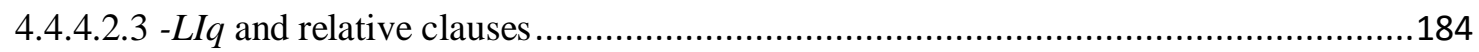

4.4.4.2.4 A short digression: non-finite clauses followed by -LIq in other Turkic languages . 186

4.4.4.3 Correlation between $-L I q$ and the agreement marking ................................. 187

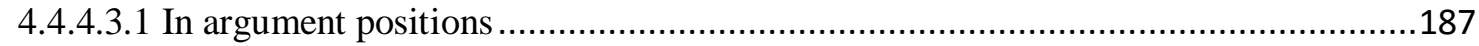

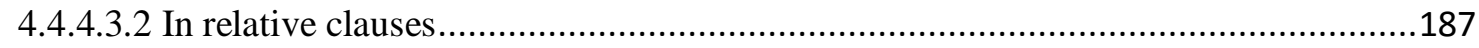

4.4.4.3.3 As complements of semantic cases and postpositions .......................................188

4.4.4.3.4 -(A)r-headed complement clauses of semantic cases and postpositions ..................193

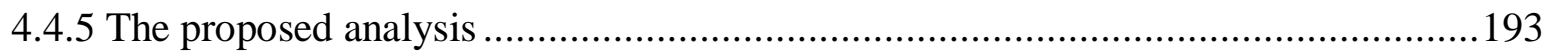

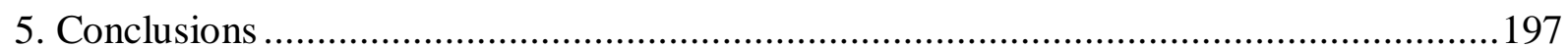

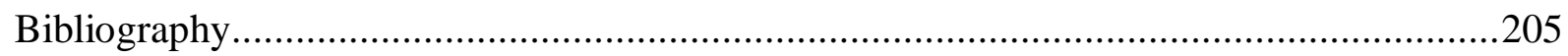

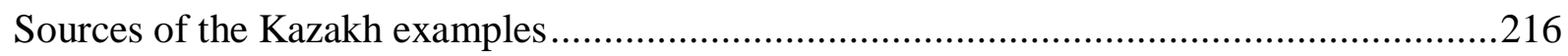

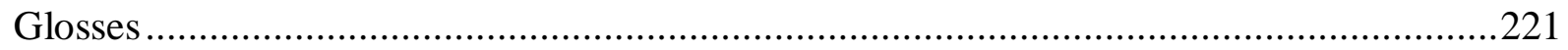

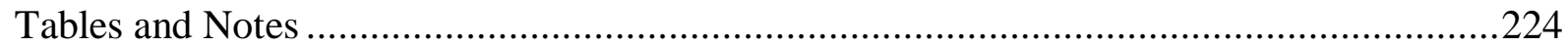

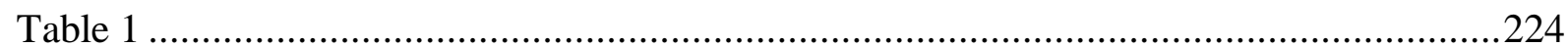

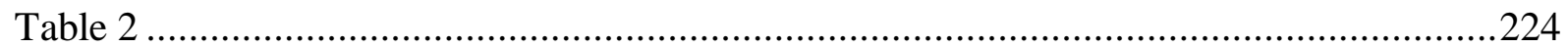

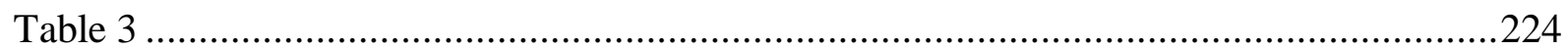

Some notes on the terms "Converbial tenses" and "Converbial agreement markers" ..........225

Some notes on the transcription of the Kazakh examples ..............................................231

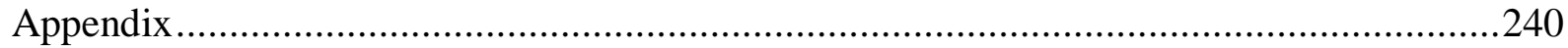

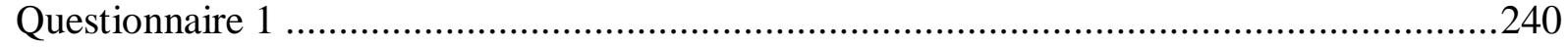

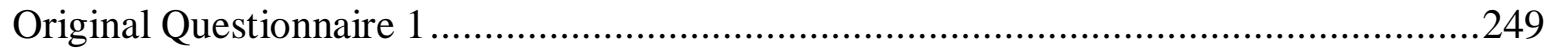

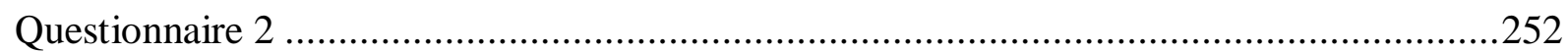

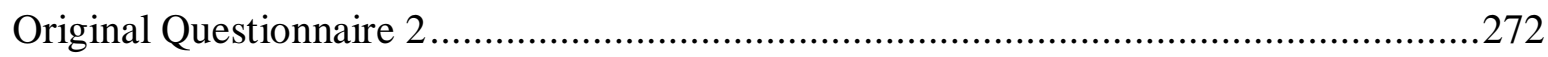




\section{Acknowledgements}

I am very grateful to my teachers for their advice and support. First of all, I would like to express my gratitude to András Róna-Tas, whose strict standards in scholarship have guided me during my work. I am in debt to Mária Ivanics for her help in contacting Kazakh universities and finding founding for my field trips. I have benefited a lot from István Kenesei's syntax seminars and his useful comments on my work. I am very thankful to Éva Kincses Nagy for putting her faith in me, and giving me a great deal of professional and personal support. I would like to express my gratitude to Éva Dékány, too, for her very useful remarks on the first version of the dissertation. Moreover, I am very thankful to all of my colleagues at the Department of Altaic Studies at the University of Szeged for all kinds of help and assistance they provided me over the years.

I am grateful to all the Kazakh native speakers who filled out my questionnaires, and to those who helped me with the Kazakh data, particularly to Raushangül Mukusheva, Anar Abutalieva, Saule Torebekova and Aktipan Tolstoy. Raushan apai's help with the Kazakh data was especially valuable. I owe thanks to the Turkology departments of the Al-Farabi Kazakh National University (Almaty) and of the L.N. Gumilyov Eurasian National University (Astana) for making my stay and research in Kazakhstan possible. I would like to thank the staff of these departments for their help, especially Oraz Sapashev and Nurilya Gabbasovna Shaimerdinova. I am much indebted to Saule Tazhibaeva and her family for making my stay in Astana and Taraz productive and pleasant.

I would like to thank my fellow students at the Linguistic Doctoral School, especially Krisztina Andrási, Bernadett Szőke and Péter Nádasdi, for their interest in my presentations about Kazakh syntax and for their useful comments. I am greatly indebted to Ekaterina Georgieva, with whom we had very inspiring conversations about Kazakh and Udmurt nonfinite clauses accompanied by some wine or coffee. Besides her lovely company, I am very grateful for her useful corrections and comments on the dissertation.

And last but not least, I cannot tell how grateful I am for the love, support and patience of my family, my friend and colleague Figen Uç, and Greg Key. Without their support, this work would not have been born. 


\section{Introduction}

This work deals with the syntax of Kazakh non-finite clauses. Kazakh belongs to the South Kipchak branch of Turkic languages; it is manly spoken in the Republic of Kazakhstan and in the neighbouring countries such as Uzbekistan, China, Mongolia, Russia. Like the majority of Turkic languages, Kazakh is a head-final language; consequently its neutral word order is Subject-Object-Verb. Moreover, it is an agglutinative language using suffixes to express grammatical relations. In complex sentences the subordinate clauses are typically non-finite; finite subordinate clauses are rare in Kazakh, and they won't be dealt with here. (For a good introduction to the Kazakh language see Kirchner 1998a.)

\subsection{Short history of research and the aim of the dissertation}

In my view, there is a scarcity of linguistic works, especially written in English, about Kazakh. Until just a few years ago only a few introductory works were available in English, such as Alpysbaeva et al. 1995, Krippes 1996 or Somfai Kara 2002. In the last couple years however several linguistic works have been published that deal with subareas of Kazakh linguistics; such as Straughn 2011 about evidentiality and Abish 2014 about modality in Kazakh. Batayeva 2013 is also worth to be added to these, even though, it is an elementary Kazakh textbook. Moreover, by the time the final revisions of this work are completed, Raihan Muhamedowa's comprehensive Kazakh grammar ${ }^{1}$ will have been published. It is a very positive development that such works are now available in English.

Although, the number of linguistic works written in Turkish are not too numerous either, there are some noteworthy ones that I have made use of in this work. First of all, the Kazakh grammar of Koç \& Doğan (2004) and the Kazakh-Turkish dictionary of Koç et al. (2003) have to be mentioned; moreover, Tanç 2002 and Akbaba 2011 supplied useful material too.

\footnotetext{
${ }^{1}$ Muhamedowa, Raihan (2015): Kazakh. A Comprehensive Grammar. Routledge.
} 
Naturally, there are quite some Kazakh grammars published in Kazakhstan, either in Russian or Kazakh; the most notable ones are Balakaev 1959 and QG, but others too will be made reference to in the subsequent chapters. For the topic of the dissertation the following works proved to be useful too: Oralbaeva 1979, Amanžolov 1994 and Tažibaeva 2012.

Despite the growing number of linguistic works, Kazakh syntax, and especially the syntax of non-finite clauses, remains an unresearched field: grammars usually neglect this area and there are very few insightful linguistic papers on the topic. This dissertation intends to be the first in-depth contribution to this topic offering not only descriptive observations, but also an explanatory (i.e. theoretical) account on Kazakh non-finite clauses. It is noteworthy that I couch my theoretical analysis in the Minimalist Program framework, and in Chapter 2 and Chapter 3 I also use Distributed Morphology. The findings will hopefully be useful for several areas of linguistics: (the descriptive observations) for language teaching and (the theoretical analysis) for general and Turkic linguistics.

\subsection{Sources and transcription of the Kazakh examples}

The Kazakh data I made use of in this work came from several sources, which are the following:

- Kazakh literary works (fairy tales, short stories), traditional paper-based or online newspaper articles. After each Kazakh example, the abbreviation of its source is given in parentheses. The list of the sources can be found in the Appendix under the heading Sources of the Kazakh language material.

- sentences I elicited from individual native speakers. These are marked with PC (i.e. personal communication) following the sentences. For the most part, these sentences came from Raushangül Mukusheva, an excellent speaker of Kazakh, Kazakh poet, translator and language instructor at the University of Szeged, from Anar Abutalieva, who teaches Kazakh language and literature in Taraz, and from some friends of mine (notably Saule Torebekova and Aktipan Tolstoy) who are $\mathrm{PhD}$ students and teaching assistants at the L.N. Gumilyov Eurasian National University in Astana.

- two questionnaires filled out by total twenty eight Kazakh native speakers. The detailed description of these questionnaires can be found in the Appendix. (See Questionnaire 1 and Questionnaire 2.) 
As much as possible, I tried not to rely on one single person's native competence, that is why I made extensive use of the data from my questionnaires. Moreover, the sentences I quote from written texts are, I believe, from reliable sources.

We need to say a few words about the transcription of Kazakh examples. As it is wellknown, in Kazakhstan the modified Cyrillic script is still in use, despite some initiatives to (re)introduce the Latin script following the Declaration of Independence from the Soviet Union in 1990. However, the transcription of the modified Kazakh Cyrillic alphabet into Latin script is quite problematic (for reasons I expound on in the subsection Some notes on the transcription in the Appendix). Thus I have decided not to transcribe the Kazakh (Cyrillic) examples in this work. That is, the numbered examples are all given in the Cyrillic script, except for examples in table form, in syntactic trees, and lists of suffixes. On the other hand, Kazakh suffixes, words or other items mentioned in the English text are transcribed into Latin alphabet, so that the reader would not mix up Cyrillic letters with the Latin ones. (The transcription system I applied can also be found in the subsection Some notes on the transcription of the Kazakh examples in the Appendix.)

\subsection{Finite and non-finite clauses in Kazakh}

As mentioned above, this work is concerned with Kazakh non-finite clauses. First, I shall explain which clauses I consider finite and which I do not.

The underlying observation behind the traditional distinction between finite and nonfinite clauses is that root clauses (i.e. finite clauses) are different from other, typically nonroot, clauses (i.e. non-finites). That is, root clauses exhibit certain properties that are not characteristic to other type of clauses.

However, there is no agreement among linguists on what finiteness is, what the definition of finiteness is. That is, it is difficult to give a cross-linguistically valid characterization of finite and non-finite clauses. This is because languages may differ radically from each other with respect to the properties that distinguish their finite and nonfinite clauses. For instance, in Indo-European languages spoken in Europe non-finite clauses, unlike finite ones, lack Tense and Agreement. However, this distinction (i.e. Tense and Agreement in finite clauses, no Tense and Agreement in non-finite clauses) does not hold in other languages: for example, in Kannada, a Dravidian language, there is no Tense in infinitives, but participles, gerunds and dependent conditionals have Tense marking 
(Nikolaeva 2007: 1). Nikolaeva (2007: 1-4) mentions several such instances from various languages. For this reason, quite a number of linguistic works have argued that finiteness (in the traditional sense) is not a cross-linguistically relevant primary category (cf. Cristofaro 2007 for a functional-typological account).

Moreover, it has also been questioned whether the category of finiteness (in the traditional sense) is truly needed to account for the distinction between different types of clauses in individual languages (Adger 2007). To put it in other words, it is not clear whether finiteness is a primary category, or it is secondary, and it can be derived from other - primary - categories. Adger (2007) states the traditional notion of finiteness does not have a true relevance in grammar, and the phenomena traditionally associated with finiteness can be explained otherwise. (Note that this does not entail that he denies the existence of a finite category entirely.)

A further problem is that in individual languages non-finite clauses do not form a uniform class. That is, types of non-finite clauses in a certain language may differ from each other significantly. For example, Adger (2007) shows that certain non-finite clauses in Gaelic have different syntactic structure. It will be shown that, similarly to Gaelic, Kazakh non-finite clauses do not form a unified class either. Therefore, the fact that even in one language the non-finite clauses are different from each other, seriously undermines the concept of cross linguistically valid (non-)finiteness.

These problems lead generative linguists to abandon the traditional notion of finiteness ascribing new analyses to it. Subsequently to Rizzi's (1997) seminal work on the split C-domain, several authors proposed that there is a projecting Finite head in the Cdomain, whose properties may differ considerably from the traditional concept of finiteness (e.g. Bianchi (2003), Adger (2007), etc.). Moreover, several such approaches attempted to correlate this Finite head with Tense and Agreement properties.

Before we turn to the applicability of these approaches to Kazakh, some crucial differences will be given between clauses that I consider finite and non-finite.

First of all, subject agreement is obligatorily present on the predicate of finite clauses, as shown in (1). Finite sentences are ungrammatical without the subject agreement marking. (Note that in singular and plural third person the subject agreement marking is zero.)

(1) Сен құзақ-ша сөйле-й-*(сің).

you Kazakh-ADV speak-PRES-SG2 
Two types of agreement paradigms are used in finite clauses: the so-called "z-paradigm" (in (2)) and "k-paradigm" (in (3)). ${ }^{2}$ The Inflection and Tense Copula heads ${ }^{3}$ that the agreement follows determine which type of agreement morpheme must be used. For example, the Inflection head $-y / A(d I)$, shown in example (1), must be followed by the agreement suffixes of the z-paradigm; whereas the Inflection head -DI, which expresses past, is followed by morphemes belonging to the k-paradigm.

(2) z-paradigm

$\begin{array}{ll}\text { SG.1 } & -M I n \\ \text { SG.2 } & -s I \eta \\ \text { SG.FORML } & -s I z \\ \text { SG.3 } & -\varnothing \\ \text { PL.1 } & -M I z \\ \text { PL.2 } & -s I \eta d A r \\ \text { PL.FORML } & -s I z d A r \\ \text { PL.3 } & -\varnothing\end{array}$

(3) k-paradigm

$\begin{array}{ll}\text { SG.1 } & -m \\ \text { SG.2 } & -\eta \\ \text { SG.FORML } & -\eta I z \\ \text { SG.3 } & -\varnothing \\ \text { PL.1 } & -q \\ \text { PL.2 } & -\eta d A r \\ \text { PL.FORML } & -\eta I z d A r \\ \text { PL.3 } & -\varnothing\end{array}$

${ }^{2}$ There is a widely held opinion in the literature that there is a third agreement paradigm. See the subsection Some notes on the terms "Converbial tenses" and "Converbial agreement markers" in the Appendix for a discussion that refutes these claims.

${ }^{3}$ For a detailed representation of Inflection and Tense Copula heads see Table 1 in the Appendix. 
In contrast, subject agreement can either not be indicated on non-finite predicates (e.g. in converb clauses), or if it can be, the agreement suffix used belongs to the possessive paradigm, and not to the $\mathrm{z}$ - or $\mathrm{k}$-paradigm. In the following illustrative example the non-finite - $\dot{G} A n$-suffix, which heads a subordinate clause indicated with square brackets, is followed by an agreement suffix that belongs to the possessive paradigm. Chapter 4 discusses in which types of non-finite clauses can the nominal agreement marking (i.e. the possessive) be present.

$$
\begin{aligned}
& \text { Өмірбек [өткен апта Алмать-да бол-ван-ылн] айт-ты. (PC.) } \\
& \text { Ömirbek [last week Almatï-LOC COP-NF-POSS.3]ACC }{ }^{4} \text { say-PAST.3 } \\
& \text { 'Ömirbek said that he was in Almaty last week.' }
\end{aligned}
$$

In (5) the possessive paradigm is given. Even though, the k-paradigm shares some similarities with the possessive paradigm, they are distinct without doubt: consider the suffixes in singular third person, and throughout the plural.

(5) Possessive paradigm

$\begin{array}{ll}\text { SG.1 } & -(I) m \\ \text { SG.2 } & -(I) \eta \\ \text { SG.FORML } & -(I) \eta I z \\ \text { SG.3 } & -(s) I \\ \text { PL.1 } & -(I) m I z \\ \text { PL.2 } & (\text { PL })-(I) \eta \\ \text { PL.FORML } & (\text { PL })-(I) \eta I z \\ \text { PL.3 } & \text { (PL) }-(s) I\end{array}$

\footnotetext{
${ }^{4}$ This glossing requires some explanation: in the Kazakh sentence there is no overt morpheme outside the brackets, still in the glossing, an accusative morpheme is indicated. In Kazakh, if a case (e.g. accusative, dative, locative etc.) follows the possessive singular or plural $3^{\text {rd }}$ person suffix $(-(s) I)$, the so-called pronominal $n$ appears between the possessive and the case suffix. (Note that this pronominal $n$ is generally not glossed separately.) An example with the locative is offered in (i):

(i) $\quad y \check{u}-i-\boldsymbol{H}-\partial e$ house-POSS.3-pronominal n-LOC

'in his/her/their house'

In Kazakh, the accusative suffix after the third person possessive is always covert; however, the presence of the pronominal $n$ indicates that there is indeed an accusative suffix following the possessive suffix.
} 
A further difference between Kazakh finite and non-finite clauses is that in finite clauses Inflection heads can be followed by a Tense Copula head (cf. Table 1 in the Appendix). An illustrative example is offered in (6), where the finite $-y / A(d I)$ is followed by the Evidential Copula eken. The copulas eken and edi can never follow the predicates of non-finite clauses.

(6) Әйел-дер ер-лер-ге ққараванда 3 есе көп сөйле-йді екен. (NET-BAQ2) woman-PL man-PL-DAT compared.to 3 times many speak-PRES COP.EVID.3

'Women talk three times more than men, they say.'

Moreover, polar questions are different in finite and in non-finite clauses (or to be more precise, in the non-finite clause types in which polar questions are allowed). ${ }^{5}$ In finite clauses, polar questions are formed with the so-called question particle $M A$, which follows the Inflection head, but precedes the Tense Copula. It is noteworthy that Kazakh $M A$, unlike Turkish $m X$, cannot follow any other constituent but the predicate of the sentence.

$$
\begin{aligned}
& \text { Қасқыр сөйле-йме екен? (NET-ZhÖQ) } \\
& \text { wolf speak-PRES Q COP.EVID.3 } \\
& \text { '(What do you think) does the wolf speak?' }
\end{aligned}
$$

The question particle $M A$ cannot be used with non-finite predicates; in case of non-finites, the polar questions are formed the following way: verb+non-finite suffix followed by (the same) verb+negation+non-finite head.

$$
\text { Ана-м [қарындас-ылм-ның Үй-ден }
$$

mother-POSS.SG1 [sister-POSS.SG1-GEN house-ABL

$$
\text { шық-қан-шық-па-ган-ын] сұра-дыл. (РС) }
$$

leave-NF leave-NEG-NF-POSS.3]ACC ask-PAST.3

'My mother asked whether my sister left from home.'

The last two differences between Kazakh finite and non-finite clauses can be explained by truncation; that is, non-finite clauses lack certain "higher" functional

\footnotetext{
${ }^{5}$ There is no difference between finite and non-finite clauses with respect to $w h$-questions. Note that there is no wh-movement in Kazakh, that is, wh-words are in-situ.
} 
projections (such as Tense expressed by Tense Copulas, or question operator, which is responsible for polar questions) that are present in finite clauses. This is absolutely in line with the claims made in the literature about non-finite clauses (e.g. see Adger 2007). In Chapter 2 (and partly in Chapter 3), in which the structure of non-finite clauses will be analyzed, it will be pointed out that certain non-finite clauses include fewer functional categories (i.e. they are more truncated) than others.

As for the difference between agreement marking patterns between finite and nonfinite clauses (cf. the first point above), it needs to be explained why there is always agreement marking in finite clauses while some non-finite clauses lack it entirely, or express it with possessive suffixes. The latter fact will be discussed in Chapter 4, in which it will be demonstrated that the nominal agreement suffixes (i.e. the possessive) can only be present in nominalized non-finite clauses, otherwise the agreement cannot be indicated in non-finite clauses. As for why is it the case that the agreement must be present in Kazakh finite clauses but not in non-finites, there might be several explanations. For instance, one could assume that a Finite head (or its features) are responsible for the presence of agreement in finite clauses. If this is indeed so, truncation would again explain why non-finite clauses lack agreement: if they lack a Finite head, the agreement cannot appear in them either. However, in this work we cannot undertake to give a final solution to this problem, because for that it would be an absolute imperative to analyze Kazakh finite clauses in detail too, which task is out of the scope of the present study.

Therefore, I propose that the main difference between Kazakh finite and non-finite clauses is that the latter ones have truncated structure (to various degrees). The subsequent chapters will address in detail what structure non-finite clauses have.

\subsection{A short description of Kazakh non-finite clauses}

I distinguish three main types of non-finite clauses: converb clauses, nominalized clauses and "Inflectional non-finite clauses".

\subsubsection{Converb clauses}

Clauses headed by converb morphemes can be used as adverbial clauses without any further suffix (e.g. the locative or ablative semantic cases, postpositions etc.) added to them. The 
converb heads and the meaning of their clauses are given in table (9). (Note that a revised version of this table will be offered in Chapter 2.)

(9) Converb heads and their meanings (preliminary version)

\begin{tabular}{|l|l|}
\hline Converb heads & Meaning (roughly) \\
\hline$-(I) p$ & $\begin{array}{l}\text { 'after', 'when'; } \\
\text { '-ing' (manner); } \\
\text { 'and'; } \\
\text { 'as'; } \\
\text { 'since' (causal) etc. }\end{array}$ \\
\hline$-y / A$ & '-ing' (manner) \\
\hline$-M A y$ & $\begin{array}{l}\text { Negative allomorph of -(I)p and }-y / A ; \\
\text { 'without'; }\end{array}$ \\
\hline$-\dot{G} A l I$ & 'until' \\
\hline$-\dot{G} A \sin$ & 'since'; \\
& 'in order to' \\
\hline$-M A y \operatorname{In} \check{A} A$ & 'when'; \\
\hline
\end{tabular}

In what follows, I will offer a few illustrative examples with the above-given converb heads. The -(I)p-clause in (10) has some sort of vague temporal ('when'/ 'after') relationship to the matrix predicate (taydan- 'be astonished') it modifies. A detailed description of -(I)p-clauses will be given in Chapter 3, which is entirely dedicated to them.

(10) [Mүны көр-in], Товыз Тоңққылдақ mіпті қ̧атmы таңудан-ады. (KV, TTBS)

[this.ACC see-CV] Tog̈ïz Tonqïldaq quite much be.astonished-PRES.3

'(After) seeing this, Togyz Tonkyldak [who were nine brothers] were $^{6}$ very astonished.'/ 'Togyz Tonkyldak saw this, and they were very astonished [by it].'

\footnotetext{
${ }^{6}$ Note that in some examples the glossing indicates present, but in the translation the verb is in past tense. The reason for this is that these examples are taken from fairy tales, and the Inflection head $-y / A(d I)$, which in other contexts expresses present, functions as a "narrative tense" in tales and stories. (It is comparable to the Turkish Aorist in this regard.) These are best translated as past tense into English, however.
} 
$-y / A$-headed converb clauses express manner, as shown in (11). 
they each.other.DAT [smile-CV] look-PAST.3

'They looked at each other smilingly.'

In (12), $-M A y$ is used as the negative allomorph of $-(I) p$. However, note that $-M A y$ has usages which seem to be independent from $-y / A$ or $-(I) p$. For instance, it may have the meaning 'without (doing something)', as shown in (13). Hence it is justified to treat $-M A y$ as an independent converb head.

Хан [жау-ды женъ-е ал-май],

khan [enemy-ACC overcome-A LV-NEG.CV]

төрт-бес жыл содыс-та бол-ады. (KV, HMV)

four-five year war-LOC COP-PRES.3

'Not being able to overcome the enemy, the khan spent four or five years in war.'

(13) Патиа [...] [ешкім-ге біл-дір-мей] көше-де жүр-етін бол-ды. (KV, QP) padishah [no.one-DAT know-CAUS-CV] street-LOC walk-HABIT COP-PAST.3 'The padishah [...], without letting anyone know, was walking on the streets.'

The converb head - $\dot{G} A l I$ has two significantly different usages. In order to distinguish these I am using the upper indices $\left(-\dot{G} A l I^{1}\right.$ and $\left.-\dot{G} A l I^{2}\right)$. The temporal adverbial clauses headed by $-\dot{G} A l I^{l}$ express 'since...', while those by $-\dot{G} A l I^{2}$ express the goal, the purpose of the superordinate clause's action. ${ }^{7}$ Example (14) illustrates the former case. (Note that the $-\dot{G} A l I^{1}$ clause can be optionally followed by the postposition beri 'since'. This will be dealt with in Chapter 4.)

\footnotetext{
${ }^{7}$ - $\dot{G} A l I$ exhibited both of these usages even in the earliest written sources, such as in the Orkhon inscriptions (Tekin 1968: 184-185); but these two usages are also present in Chagatai (Middle Turkic) texts. It seems that most of the modern Turkic languages lost one of these meanings (most often the purposive one), but there is a group of languages in the same area where Kazakh is spoken in which both of these functions are preserved. Thus similarly to Kazakh - $\dot{G} A l I$, Kirghiz - $\dot{G} A n I /-\dot{G} O n U$ (Kirchner 1998: 352, Kasapoğlu Çengel 2005: 314-315) and Uighur -Gili (Pritsak 1959: 555) have both terminal and purposive meanings.
} 
[Kazakhstan independence get-CV] since 1 million approximately

құандас-ьлмыз тарихи отан-ьнна орал-дыл. (NET-I)

kinsman-POSS.PL1 historical homeland-POSS.3.DAT return-PAST.3

'Since Kazakhstan gained independence, about one million of our kinsmen have returned to their historical homeland.'

The purposive $-\dot{G} A l I^{2}$ is used very rarely. I have observed that the purposive $-\dot{G} A l I^{2}$ can only be used with superordinate predicates that express motion towards something (such as 'to go', 'to leave' etc). ${ }^{8}$ As shown in (15), since the superordinate predicate express motion (kel- 'to come'), it is grammatical to use a - $\dot{G} A l I^{2}$-headed converb clause to indicate the purpose of the superordinate predicate. ${ }^{9}$

Әйел-i [түрме-де-гі күйеу-ін көр-гелі] кел-іпті. (NET-MKK) wife-POSS.3 [jail-LOC-ADJ husband-POSS.3.ACC see-CV] come-EVID.3

'His wife came to see her husband who is in jail.'

Converb clauses headed by -GAsIn can have the meaning 'when' or 'because of'. The former is illustrated in the following example. (There will be an example offered for the latter meaning in Chapter 2.)

\footnotetext{
${ }^{8}$ This generalization seems to hold for all the purposive usages of the converb head in the modern languages where it exists, and also in old texts. For the latter, see the examples in Tekin 1968 (184-185) and in Erdal 2004 (488-189). Nevskaya (2010: 163) also notes that in Old Turkic the superordinate predicates of the purposive - $\dot{g}$ AlI-clauses are "very often $[\ldots]$ verbs of motion".

${ }^{9}$ It is noteworthy that $-\dot{G} A l I^{2}$ is not interchangeable with $-w$ üšin purpose clauses, which are the most commonly used purpose clauses. This is shown in (i) and (ii): the $-w \ddot{u} s ̌ s i n$ construction cannot be replaced by $-\dot{G} A l I^{2}$ (cf. the ungrammatical (ii)).

(i)

you.SG.FORML [Germany-DAT enter-NNF] for visa get-NNF-POSS.SG.FORML necessary

'You have to get a visa in order to enter Germany.'

*[Германия-ва кір-гелі] виза ал-у-ыңыьз керек. (РС.)

[Germany-DAT enter-CV] visa get-NNF-POSS.SG.FORML necessary Intended: 'You have to get a visa in order to enter Germany.'
} 
[Егістік-ке бар-васын] Қизат өгіз-ді тоқтат-ыл,

[field-DAT go-CV] Qïyzat cart-ACC stop-CV

бір жак̧-қ̧а кет-іп қ̧ал-ды. (M/N-GSB)

one side-DAT leave-IP LV.CONT-PAST.3

'When [we] went to the field, Kiyzat stopped the cart and went somewhere.'

The converb clauses headed by -MAyInšA express 'as long as (someone does not do something)'. The negative suffix $-M A$ - can be discovered in $-M A y \operatorname{InšA}$; it is noteworthy that there is no affirmative form of this morpheme.

[Бұлар-дың бір-ін істе-мейінше]

[these-GEN one-POSS.3.ACC do-CV]

бұл жер-ден шық-па-й-сың. (NET-BA)

this place-ABL leave-NEG-PRES-SG2

'As long as you don't do one of these, you can't leave this place.'

Note that I did not include $-s A$-headed (desiderative, conditional or temporal) clauses in the list of converb heads. This is because the agreement (of the k-paradigm) must be indicated on them, hence I consider them finite.

\subsubsection{Nominalized clauses}

The suffixes $-w,-(I) s$ and $-M A q$ can nominalize larger verbal structures. (Note that in Chapter 4 it will be proposed that $-\dot{G} A n,-y / A t I n$ and $-(A) r$-headed clauses can be nominalized as well. In this general introduction these cases won't be addressed.) Nominalized non-finite clauses can occur in the syntactic positions where 'regular' noun phrases can: for instance, in argument position (e.g. as direct objects) or as complements of semantic cases or postpositions etc. The former case is illustrated in (18), in which the $-w$-headed clause is the object of the superordinate predicate umït- 'to forget'.

[Маван хат жаз-y]-ды ұмыз-па.

[I.DAT letter write-NNF]-ACC forget-NEG.IMP.SG2

'Don't forget to write me a letter/letters.' 
Table (19) summarizes the most common cases when an -w-clause is the complement of a semantic case or a postposition. -INSTR birge 'together with' and üšin 'for' are postpositions, $\check{S} A$ is a semantic case expressing 'like, as'.

(19) - $w$-clauses as complements of semantic cases or postpositions

\begin{tabular}{|l|l|l|}
\hline Nominalizer & Semantic case / Postposition & Meaning (roughly) \\
\hline$-w$ & - INSTR birge & $\begin{array}{l}\text { 'together with (an event)', } \\
\text { 'though', 'nonetheless' }\end{array}$ \\
\hline$-w$ & $-\breve{s} A$ & 'according to' \\
\hline$-w$ & $\ddot{u}$ šin & 'in order to' (purpose clauses) \\
\hline
\end{tabular}

Two illustrative examples are given below with such $-w$-clauses. In (20) the $-w$-clause is the complement of the semantic case $-\check{s} A$, and in (21) of the postposition -INSTR birge 'together with'.

[Саудагер-лер-дің айт-y-ын]-им, жаңуа базар-да [tradesman-PL-GEN say-NNF-POSS.3]-šA new marketplace-LOC жал-ва бер-у құн-ы тым жовары. (NET-ATV) rent-DAT give-NNF price-CM too high

'According to what the tradesmen say, at the new marketplace the renting costs are too high.'

(21) [Соны айт-y]-мен бірге осы бүгін-гі ниет-ке бекін-ді. (Tanç 2002: 190) [that.ACC say-NNF]-INSTR together that today-ADJ purpose-DAT strengthen-PAST.3 'Even though (s)he said that (i.e. what had been stated earlier), (s)he was getting ready for the aim of that day.'

Note that other usages of $-w$-clauses (for instance, in modal constructions with kerek 'necessary' or together with the verb bol- expressing possibility) are not listed here.

Although $-(I) s$-headed clauses can appear in argument position, their most frequent usage is as complements of the instrumental semantic case. In this case the (nominal) agreement is obligatory marked on the $-(I) s$-head. This is the reason why most grammars give 
this "complex" form as -(I)sImen, where the $I$ following the nominalizer head $-(I) s$ would indicate the third person possessive (i.e. agreement) suffix. (Naturally, the nominal agreement marker can be other than third person, e.g. it can be singular first person: -(I)sImmen.) $-(I) s+$ POSS + -men adverbial clauses mean 'as soon as', 'at the moment when'. An illustrative example is given below.

[Шыз-ыс-ы]-мен алма-сы қол-ьинан

[leave-NNF-POSS.3]-INSTR apple-POSS.3 hand-POSS.3.ABL

myc-in кет-mi. (Balakaev 1959: 185)

fall-IP LV.C-PAST.3

'The moment (s)he left [the room], his/her apple fell out of his/her hand.'

The usage of $-M A q$-headed nominalized non-finite clauses is extremely marginal. -MAq-headed clauses can be either the complements of modal non-verbal words (for example, kerek 'necessary') or the postpositions üšin 'for' and tügil 'not even', or the dative case ${ }^{10}$ expressing the aim of the superordinate predicate. The construction $-M A q$ bolïp $(<$ bol- 'to become; copula' $+-(I) p)$ is also worth mentioning, which expresses the purpose of the superordinate predicate.

\subsubsection{Inflectional non-finite clauses}

The non-finite heads $-\dot{G} A n,-y / A t I n$ and $-(A) r$ belong to this group. I call them "Inflectional" non-finites for reasons that will become clear in Chapter 2. For the sake of a short introduction, it is noteworthy that these non-finite heads differ from each other in terms of Aspect. Non-finite $-\dot{G} A n$ expresses either perfect aspect, or if it follows Continuous "auxiliaries" (see 2.1.3.4 for details about Continuous "auxiliaries"), the construction expresses continuous Aspect. Non-finite -y/AtIn is either habitual, or it refers to prospective events that are going to happen at a given time in the future. Non-finite $-(A) r$ indicates prospective events that will take place sometime in the future, but it is not known when exactly.

\footnotetext{
${ }^{10}$ This usage seems to be especially marginal. (For an example see Amanžolov 1994: 292-293.)
} 
Non-finite clauses headed by these non-finite suffixes can turn up in three different syntactic positions: as relative clauses, as argument clauses or as complement clauses of semantic cases or postpositions. Sentence (23) illustrates the relative clause usage. Notice that the Continuous "auxiliary" $-(I) p \check{z} a t$ - is followed by the non-finite head $-\dot{G} A n$, and that the construction expresses continuous aspect.

(23) Батыр-лар бар-ыл олар-ды [ұйқта-п жат-қан] жер-ін-де Ұста-n, soldier-PL go-CV they-ACC [sleep-IP LV.CONT-NF] place-POSS.3-LOC capture-CV байла-п патша-ва ал-ыл кел-еді. (KV, QP)

tie-CV padishah-DAT take-IP come-PRES.3

'The brave soldiers went [there], captured them at the place where they were sleeping, tied them up and took them to the padishah.'

In (24) the $-y / A t I n$-headed clause is the argument (the object) of the matrix predicate ayt- 'to tell'. In this sentence the habitual $-y /$ AtIn-head is used, expressing the subject's general intention to change her life.

Маржан Арапбаева Гөмір-ін-де не-ні

Maržan Arapbaeva [life-POSS.3-LOC what-ACC

өзгерт-кі-сі кел-етін-ін] айт-ты. (NET-N)

change-GI-POSS.3 COP $^{11}$-NF-POSS.3]ACC tell-PAST.3

'Marzhan Arapbayeva told [us] what she wants to change in her life.'

"Inflectional" non-finite heads can also be complements of semantic cases or postpositions. The following table gives a summary about the most common such instances. (The table is based on my research and on several other sources, such as: Tanç 2002, QG, Ïsqaqov 1967/II, Balaqaev \& Isqaqov 1954.)

\footnotetext{
${ }^{11}$ The construction verb- + - $\dot{G} I+$-POSS kel- expresses 'to want to do something'.
} 
(25) $-\dot{G} A n,-y / A t I n$ and $-(A) r$-headed clauses as complements of semantic cases or postpositions

\begin{tabular}{|c|c|c|}
\hline $\begin{array}{l}\text { Inflectional non-finite } \\
\text { heads }\end{array}$ & Semantic case/ Postposition & Meaning (roughly) \\
\hline$-\dot{G} A n$ & -DA (locative semantic case) & $\begin{array}{l}\text { 'when', 'after'; } \\
\text { 'if'; } \\
\text { 'while' }\end{array}$ \\
\hline$-(A) r$ & -DA (locative semantic case) & $\begin{array}{l}\text { 'before } \quad \text { (something } \\
\text { happens)' }\end{array}$ \\
\hline$-\dot{G} A n-d I q^{12}$ & -DAn (ablative semantic case) & 'since', 'because of' \\
\hline$-y / A t I n-d I q$ & -DAn (ablative semantic case) & 'since', 'because of' \\
\hline$-M A s$ & -DAn (ablative semantic case) & $\begin{array}{l}\text { 'not doing something', } \\
\text { 'without doing something' }\end{array}$ \\
\hline$-\dot{G} A n$ & -DAy (semantic case 'like', 'as') & 'similarly to', 'as' \\
\hline$-y / A t \operatorname{In}$ & -DAy (semantic case 'like', 'as') & 'similarly to', 'as' \\
\hline$-M A s^{13}$ & -DAy (semantic case 'like', 'as') & 'similarly to', 'as' \\
\hline$-\dot{G} A n$ & -šA (semantic case 'like', 'as') & $\begin{array}{l}\text { 'until'; } \\
\text { 'unless', 'as long as'; } \\
\text { 'as', 'the same way as'; } \\
\text { 'instead of' }\end{array}$ \\
\hline$-\dot{G} A n$ & $\begin{array}{lll}\text {-Men } & \text { (instrumental semantic } \\
\text { case) } & & \\
\end{array}$ & 'despite of', 'together with' \\
\hline$-\dot{G} A n$ & $(-\mathrm{ABL})^{14} \operatorname{so\eta }$ ('after') & $\begin{array}{l}\text { 'after'; } \\
\text { 'because of' }\end{array}$ \\
\hline$-\dot{G} A n$ & -ABL keyin ('after') & 'after' \\
\hline$-M A s$ & (-ABL) burïn ('before') & 'before' \\
\hline$-(A) r$ & aldïnda ('before') & 'before' \\
\hline$-\dot{G} A n$ & -ABL beri ('since') & 'since' (temporal) \\
\hline$-\dot{G} A n$ & sayï ('every') & 'every time when' \\
\hline$-\dot{G} A n$ & üšin 'for' & 'because', 'since' \\
\hline
\end{tabular}

${ }^{12}$ Chapter 4 includes a long discussion about such forms. For now it is enough to say that $-d I q$ is an allomorph of - LIq.

${ }^{13}-M A s$ is the negative allomorph of $-(A) r$.

${ }^{14}$ The parenthesis indicates that the ablative case assigned by postposition is not obligatorily present. 


\begin{tabular}{|c|c|c|}
\hline$-y / A t \operatorname{In}$ & üšin 'for' & 'because', 'since' \\
\hline$-M A s$ & üšin 'for' & 'in order to' \\
\hline$-\dot{G} A n$ & -DAT qaramastan ('despite') & 'despite of' \\
\hline$-\dot{G} A n$ & twrali ('about') & 'about (an event)' \\
\hline$-y / A t \operatorname{In}$ & twrali ('about') & 'about (an event)' \\
\hline
\end{tabular}

A few illustrative examples are given below. In sentence (26) the constructions -y/AtIndAy and $-y /$ AtIn $\ddot{\text { šin }}$ can be found. In both of these cases -y/AtIn expresses habitual aspect.

[Өз-іңіз біл-етін]-дей, [жарық дүние-ні дұрыс

[self-POSS.FORML know-NF]-like [bright world-ACC properly

көр-ме-йтін-діг-ім] Үшін, кейбір көз-ді

see-NEG-NF-LIq-POSS.SG1] for some eye-ACC

қ̧ажет ет-етін жұмыс-тар-ды атқ̧ар-у құиын бол-ды. (M/N-KMK)

necessary LV-NF work-PL-ACC perform-NNF hard COP-PAST.3

'As you know it yourself, since/because I don't see the visible world, taking care of some works that require eye(sight) was difficult.'

In the following example $-\dot{G} A n$ followed by the postposition (-ABL) soy 'after' marks a causal adverbial clause.

(27) ... бірақ [жалвыз бол-ван] соң, кір-е ал-май тұр е-ді-м. (KV, QP) but [alone COP-NF] after enter-A LV-MAy LV.CONT.PRES COP.PAST-SG3 '[...] but because I was alone, I wasn't able (at that moment) to go in.'

Chapter 4 will discuss the syntactic properties of nominalized and Inflectional non-finite clauses in detail. This section gives only a short overview about the non-finite clause types than will be discussed in the next chapters. 


\subsection{Overview of the dissertation}

The chapters of the dissertation aim at giving answers to questions or issues surrounding Kazakh non-finite clauses. Chapter 2 raises the following questions:

- What syntactic positions do non-finite heads take? (Cf. 2.1.)

- Which non-finite clauses can have an overt, independent subject? (That is, a subject that is different from the subject of the matrix clause.) (Cf. 2.2.)

- Why can certain non-finite clauses have independent subjects, while others cannot? How are these clauses (syntactically) different?

After Chapter 2 has given an introduction to all Kazakh non-finite clauses, issues of individual non-finite clauses will be discussed. Chapter 3 deals with the following questions concerning Kazakh -(I)p-clauses:

- How could it be explained that -(I)p-clauses have a very wide range of meanings (e.g. temporal, causal, simple linking (i.e. 'and'), manner, purpose meanings)? (Note that no other non-finite clauses may have so many, sometimes very different, meanings.)

- How could it be explained that $-(I) p$ can head subordinated and coordinated clauses as well? (For evidence that $-(I) p$ can indeed head coordinated clauses, see 3.4.) Chapter 4 discusses clauses headed by $-w,-\dot{G} A n,-y /$ AtIn and $-(A) r$, which can turn up in different syntactic positions (such as in argument positions, as complements of semantic cases, postpositions or, at least some of them, as heads of relative clauses). It will be discussed

- how these non-finite clauses are different from each other (e.g. based on agreement marking patterns).

- how the (syntactic) difference between these clauses could be explained. What syntactic features are responsible for this difference?

As it may be evident from the above questions, the present work aims at being not only a descriptive, but also an explanatory account on Kazakh non-finite clauses. 


\section{Syntactic position of non-finite heads and subjects of non-finite clauses}

This chapter includes two main parts: 2.1 deals with the syntactic position of the abovediscussed non-finite heads; section 2.2 discusses what types of non-finite clauses can have an independent subject (i.e. independent from the subject of the matrix clause), and if there can be an overt subject, what case it bears. As it will become clear by the end of this chapter, these two things, i.e. the syntactic position of a non-finite head and overt independent subjects, are closely related.

As it will be shown, the distribution of non-finite heads with respect to "verb-CV verb" (traditionally called: auxiliary) constructions is an important factor in determining the syntactic positions of these non-finite heads. Thus we need to start our work with Kazakh "verb-CV verb" constructions: we are going to touch upon these constructions in 2.1.1 - 2.1.4. This vast topic would provide enough material for more than one dissertation, so naturally, this tiny section cannot be exhaustive. Nevertheless, the discussion of the topic is inevitable, for the presence or absence of the "verb-CV verb" constructions in non-finite clauses helps us determine the syntactic position the non-finite head occupies. In 2.1.5 it will be shown that the majority of non-finite heads can embed "verb-CV verb" constructions; however, not all of them can do so (e.g. $-y / A$ cannot). This helps us to determine two different structural positions that non-finite heads can occupy: a low and a high position.

In 2.2.1 it will be presented which non-finite clauses can have an independent subject. In the subsequent 2.2.2 section it will be pointed out that those non-finite clauses whose head can embed "verb-CV verb" constructions can have an independent subject; however, those non-finite clauses whose head cannot embed "verb-CV verb" constructions cannot have an independent subject. Thus it will be argued that the syntactic position of the non-finite head is interrelated with the possibility of overtly indicating the subject in the non-finite clause. The chapter ends with the presentation of the subject case assignment in different non-finite clause types. 


\subsection{Syntactic position of non-finite heads}

\subsubsection{How to form "verb-CV verb" constructions?}

"Verb-CV verb" constructions (traditionally called "auxiliary" constructions) are one of the most characteristic property of the Kipchak, Turki and South Siberian Turkic languages. Many linguistic works have been devoted to this topic, such as the following monographs: Oralbaeva 1979, Schönig 1984, Akbaba 2011 etc.

"Verb-CV verb" constructions are formed the following way: a "converb morpheme" is added to the main verb which is followed by the inflecting verb (i.e. the "auxiliary" verb ${ }^{15}$ ), which is then followed by a finite or non-finite Inflection head (or a nominalizer). An illustrative example is given in (1), in which the "converb morpheme" $-(I) p$ attaches to the main verb iste- 'to do', and then this construction is followed by the inflecting (i.e. “auxiliary”) verb žat-. (As a heavy verb žat- means 'to lie, lie down'.) Then the Inflection head $-y / A(d I)$, which can, among other meanings, express present tense, can be seen following the "verb-CV verb" construction. The main verb + -(I)p žat- construction expresses continuousness. (Note that "verb-CV verb" constructions can be stacked on each other, in which case only the last inflecting verb bears the Inflection marker. Further discussion and examples can be found below.)

Қыз үй caл-bln, сауда-сын $\quad$ icme-n ж⿻аm-адыл. (KV, KQMM)

girl house build-CV trade-POSS.3.ACC do-IP LV.CONT-PRES.3

'After building a house, the girl was trading [with goods].' Lit.: '... she was doing her trade.'

On the surface, "converb morphemes" added to main verbs in "verb-CV verb" constructions look the same as converb heads of genuine converb clauses, but converb clauses and "verb-CV verb" constructions differ in many aspects (see the discussion below), and for this reason, I am going to treat them differently.

The following table describes how "verb-CV verb" constructions are formed in Kazakh. All inflecting verbs are listed that come up in the literature (Akbaba 2011, QG: 536-

\footnotetext{
${ }^{15}$ I refer to the so-called "auxiliary" verb as inflecting verb for the time being. But later on, it will be established that it is a "high light verb".
} 
545, Tanç 2002: 41-46, 83-94, 132). (Note, however, that in future research some of them might turn out not to be genuine high light verbs.) The meanings indicated after the inflecting verbs are the meanings thereof when used as heavy verbs. Their sheer goal is to provide the reader with additional information about these verbs. The inflecting verbs can be followed by finite and a number of non-finite heads (see examples (3)-(6)). 
(2) Forming "verb-CV verb" constructions

\begin{tabular}{|c|c|c|c|}
\hline Verb & $\begin{array}{l}\text { "Converb } \\
\text { morpheme" }\end{array}$ & $\begin{array}{l}\text { Inflecting verbs } \quad(+ \text { their } \\
\text { meanings as heavy verb) }\end{array}$ & $\begin{array}{l}\text { Inflection } \\
\text { Nominalizer }\end{array}$ \\
\hline & \multirow{24}{*}{$\begin{array}{l}-(I) p \\
-y / A \\
-\dot{G} A l I\end{array}$} & $a l$ - 'to take, get, get hold of' & \\
\hline & & baq- 'to take care, bring up; notice' & \\
\hline & & bar- 'to go' & \\
\hline & & basta- 'to begin' & \\
\hline & & ber- 'to give' & \\
\hline & & bil- 'to know' & \\
\hline & & bit- 'to end (intr.), be finished' & \\
\hline & & bol- 'to become; COP' & \\
\hline & & $\begin{array}{l}\text { žazda- (used only in these } \\
\text { constructions) }\end{array}$ & \\
\hline & & žat- 'to lie, lie down' & \\
\hline & & žönel- 'to leave hastily' & \\
\hline & & žür- 'to walk' & \\
\hline & & žiber- 'to send' & \\
\hline & & ket-'to go, leave' & \\
\hline & & $k \ddot{o r}$ - 'to see' & \\
\hline & & qal- 'to stay, remain' & \\
\hline & & qoy- 'to put, leave, abandon' & \\
\hline & & otïr- 'to sit, sit down' & \\
\hline & & $\ddot{o t}$ - 'to pass' & \\
\hline & & sal- 'to put' & \\
\hline & & tasta- 'to leave (tr.)' & \\
\hline & & tur- 'to stand, stand up' & \\
\hline & & tüs- 'to fall, settle, get off' & \\
\hline & & š̈̈q- 'to go out' & \\
\hline
\end{tabular}

Many of the inflecting verbs can combine with more than one "converb morpheme" (e.g. in case of the inflecting verb $a l-:-y / A$ al- and -(I)p al-). It is important to emphasise that the meaning (and the syntactic structure) of the "verb-CV verb" construction may change 
radically depending on the "converb morpheme". (Because of this, there is a tradition in Turkology that the "converb morpheme" and the inflecting verb are given together.)

For instance, $-y / A$ al- expresses ability ('to be able to do something'), while -(I)p al- is an autobenefactive form (the subject does something to his/her own advantage). Examples (3) and (4) illustrate that $-(I) p a l$ - and $-y / A$ al- constructions are different: the former is autobenefactive (as in (3)), the latter expresses ability (cf. (4)). In (3)-(4) the "verb-CV verb" constructions are followed by an Inflection marker $(-y / A(d I))$ that can be followed by an agreement morpheme. "Verb-CV verb" constructions could be followed by other morphemes as well, including the non-finite head $-\dot{G} A n$. (In (6) this non-finite clause serves as a relative clause.) Example (5) illustrates the continuous present form.

(3) Қазбай шал-ды күт-іп aл-aдbl. (KV, UT)

Qazbay old.man-ACC wait-IP ${ }^{\mathbf{1 6}}$ LV.B-PRES.3

'Kazbay waited for the old man.'

(4) Ocы іс-ті сендер-дің патша-ларың шеш-е ал-ама? (KV, ВР)

this matter-ACC you.PL-GEN padishah-POSS.PL2 solve-A LV-PRES.3 Q

'Could your padishah solve this matter?'

(5) Ойбай, қ̧онак̧-тар-ыңң осындай сөз-дер айт-ып отыр. (KV, TÜU) oh guest-PL-POSS.SG2 like.this word-PL say-IP LV.CONT.PRES.3 'Oh, what kind of words are your guests saying!'

(6) Менің біреу-де жұмыс-ым бар еді де-ген-іне I.GEN one-LOC buisness.POSS.SG1 there.is COP.PAST.3 say-NF-POSS.3.DAT жібер-іп отыр-ван күйеу-інен жомарт ешкім жоқ. (KV, TÜU) send-IP LV.CONT-NF fiancé-POSS.3.ABL generous no.one not.existing 'No one is more generous than the fiancé who let go of (his fiancée) when she said that "I have a business with someone".'

\footnotetext{
${ }^{16}$ I gloss the "converb" suffixes in "verb-CV verb" constructions as "IP" $(=-(I) p)$, "A" $(=-y / A)$ and "GALI" (= $-\dot{G} A l I)$.
} 
The "converb morpheme" - $\dot{G} A l I$ is only used with the inflecting verbs žat-, žür-, otïror tur-. This construction expresses that the action is about to happen. It is noteworthy that some works present this as a "Tense" form (e.g. Tanç (2002: 132); Akbaba (2011: 125-126, $154,228,266)$ calls it "yakin gelecek zaman kipi" 'close future tense'). In fact, the position of - GAlI žat- / žür- / oẗ̈r-/ tur- is below the Inflection position the same way, as the other "verbCV verb" constructions are that I address here (such as: Benefactive, Completive, Manner, Continuous). This is illustrated in example (7), where $-\dot{G} A l I$ otïr- is followed by the non-finite Inflection head $-\dot{G} A n$, proving that $-\dot{G} A l I$ ot $\ddot{r}$ - is indeed not in the Inflection position (since - $\dot{G} A n$ occupies that position). Due to their limited usage these constructions won't be addressed any further in this work.

[Біз ауыл-ва қ қайт-қалы отыр-ван]-да, олар да жет-ті. (QG: 542)

[we village-DAT return-GALI LV-NF]-LOC they too arrive-PAST.3

'When we were about to arrive in the village, they arrived as well.'

In contrast to $-\dot{G} A l I$, the "converb morphemes" $-y / A$ and $-(I) p$ can be used together with almost all of the inflecting verbs.

\subsubsection{Converb clauses and "verb-CV verb" constructions}

As it was mentioned above, "converb morphemes" connect the main verb with the inflecting verb in these constructions. Thus on the surface genuine converb clauses and "verb-CV verb" constructions might look the same. In (8) a converb clause is given: the superordinate predicate is al- 'to take', and the converb morpheme found on the subordinate predicate tut'to hold, accept' is $-(I) p$. Notice that the semantics of this construction is not the same as in the $-(I) p$ al-construction in (3). If $-(I) p$ is used as the head of a genuine (subordinated) converb clause, it may express (among other meanings) that the event in the main clause comes about later the one in the -(I)p-clause. 
(8)

Мен [ата-м-ның, өсиет-ін тұm-bin],

I [father-POSS.SG1-GEN will-POSS.3.ACC accept-CV]

жұма сайын қ̧ыз ал-ды-м. (KV, QUÖ)

Friday every girl take-PAST-SG1

'Following my father's will, I married a girl every Friday. '

There are, of course, many differences between the converb clauses and the "verb-CV verb" constructions. Some of these differences are the following:

- In "verb-CV verb" constructions nothing can intervene between the "converb"-marked main verb and the inflecting verb. (QG: 541, Bowern 2004: 41-43). Compare the "verb-CV verb" constructions in (3)-(6) with the sentences containing a genuine converb clause (as in (8) and (9)). The verb bearing the "converb" suffix has to be immediately followed by the inflecting verb in the former group, but not in the latter.

- In "verb-CV verb" constructions the main verb and the inflecting verb must have the same subject. This is not the case in the $-(I) p$-headed converb clauses. This is illustrated in example (9): the subject of the -(I)p-headed converb clause ('a sly boy's parents') is different from the superordinate clause's subject ('the sly boy').

(9)

$$
\text { Ерте заман-да [бір тазша бала-ның әке-шеше-сі өл-іп], }
$$

early time-LOC [one sly child-GEN father-mother-POSS. 3 die-CV]

жетім қ̧ал-ыıтmы. (KV, TB)

orphan stay-EVID.3

'A long time ago a sly boy's parents had died, and he had become an orphan.'

- "Verb-CV verb" constructions do not denote a separate event from that of the main verb (Kornfilt 2004: 3-6, Bowern 2004: 41-42). Converb clauses, however, do. If we take a look at examples (3)-(6), we will see that the main verb and the inflecting verb express only one event (for instance, there is only one event - the event of waiting - in kütip aladï (in example (3))). In contrast, in genuine converb clauses the converbmarked verb denotes an event, and the superordinate predicate does too. See example (9), in which the events of 'dying' and 'staying (an orphan)' are obviously separate events. 
- "Verb-CV verb" constructions are likely to be stressed differently from converb clauses. As far as I am aware, this issue has not yet been studied in Kazakh, but Demir (1998: 224-227) studied it in Turkish. For example, in the Turkish "auxiliary" construction in (10) the stress falls on the first syllable of the "converb"-marked verb. In contrast, in the converb clause in (11) the last syllable of the converb-marked verb is stressed. I assume that a similar distinction must hold for Kazakh, too.

(10) kóş-up dur-du (Demir 1998: 227)

run-IP AUX.CONT-PAST.SG3

'he was running around, he was continuously running'

(11) koş-úp dur-du (Demir 1998: 227)

run-CV stand-PAST.SG3

'he run and stood'

It has to be noted that the stress patterns of "verb-CV verb" constructions and single words are somewhat different, too (cf. Kornfilt 2004: 3-6). However, this does not weaken the claim that converb clauses and "verb-CV verb" constructions have different stress patters.

\subsubsection{Order of inflecting verbs (in "verb-CV verb" constructions)}

There are numerous "verb-CV verb" constructions: take into consideration that in (2) twenty four inflecting verbs were given, many of which can combine with both $-y / A$ and $-(I) p$ forming different "verb-CV verb" constructions. Add to these the "complex" inflecting verbs too that have not yet been mentioned, but are going to be discussed below. However, as it will be shown below, these "verb-CV verb" constructions form groups (such as Benefactive, Completive etc.) whose number is not all that high. (A similar approach was taken in Bowern 2004, but note that I distinguish different groups than she did.)

Since the present work cannot aim to give an exhaustive analysis of the "verb-CV verb" constructions, in the following, I am only going to focus on the most commonly used "verb-CV verb" constructions: -(I)p al- [the subject performs the action to his/her own benefit], -(I)p ber- [the subject performs the action to someone else's benefit], -(I)p qal- 
[completive], -(I)p žiber- [completive], -(I)p tasta- [completive], -(I)p ket- [completive], -y/A qoy- [manner], -y/A sal- [manner], -(I)p žat- [continuous], -(I)p žür- [continuous], -(I)p otïr[continuous], $-(I) p$ tur- [continuous]. These form four groups: the Benefactive, the Completive, the Manner, and the Continuous groups. (But keep in mind that there are many more "verb-CV verb" constructions, and there might be some other groups too.)

"Verb-CV verb" constructions belonging to a certain group have the same or only slightly different semantics. For instance, the "verb-CV verb" constructions belonging to the Continuous group express the same thing (which is continuity), or in the Manner group the "verb-CV verb" construction $-y / A$ qoy- indicates that the action or event was carried out swiftly, while in case of $-y / A$ sal- the action was carried out without paying attention (and possibly swiftly too). Another argument in favour of arranging the "verb-CV verb" constructions into groups is that those constructions that belong to the same group can never occur together, that is, they are in complementary distribution.

Moreover, I have observed that these groups are strictly ordered: for example, the Continuous can follow the Benefactive, but the Benefactive cannot follow the Continuous, and so on. As far as I know this is novel observation. The following table shows how the "verb-CV verb" constructions are ordered. A detailed discussion and evidence supporting this ordering will be presented below.

(12) Order of "verb-CV verb" constructions

\begin{tabular}{|c|c|c|c|c|}
\hline & Benefactive & Completive & Manner & Continuous \\
\hline $\begin{array}{l}\text { main } \\
\text { verb }\end{array}$ & $\begin{array}{l}-(I) p \text { al- } \\
-(I) p \text { ber- }\end{array}$ & $\begin{array}{l}\text {-(I)p qal- } \\
-(I) p \text { žiber- } \\
-(I) p \text { tasta- } \\
-(I) p \text { ket- }\end{array}$ & $\begin{array}{l}-y / A \text { qoy- } \\
-y / A \text { sal- }\end{array}$ & $\begin{array}{l}-(I) p \check{z} a t- \\
-(I) p \check{z} u ̈ r- \\
-(I) p \text { otür- } \\
-(I) p \text { tur- }\end{array}$ \\
\hline
\end{tabular}




\subsubsection{Benefactive constructions}

$-(I) p$ al- and -(I)p ber- are called here Benefactive markers: -(I)p al- expresses that the event is carried out for the advantage of the subject ${ }^{17}$, while with $-(I) p$ ber- someone other than the subject benefits from the outcome of the event (QG: 542). In her monograph on Kazakh "verb-CV verb" constructions Oralbaeva (1979: 79) notes that -(I)p al- comes immediately after the main verb. The same is true for $-(I) p$ ber-. ${ }^{18}$ Consequently, $-(I) p$ al- and -(I)p bercannot follow any other "verb-CV verb" constructions. This is illustrated by examples (13) and (15). ${ }^{19}$ In (13) the Benefactive -(I)p ber-follows the Completive -(I)p ket-, rendering the sentence ungrammatical. However, if we invert them, i.e. if the Completive follows the Benefactive, the sentence is grammatical (as in (14)). By the same token, the Continuous cannot be followed by the Benefactive $-(I) p$ ber- (see the ill-formed (15)), but other way around is possible. This small illustrative sample indicates that no "verb-CV verb" construction can precede the Benefactive.

\section{(13) *Қаваз-ва жаз-ып кет-іп бер-ді. 8/0 paper-DAT write-IP LV.C-IP LV.B-PAST.3}

Intended: '(S)he wrote it down on the paper. (for someone)'

\footnotetext{
${ }^{17}$ It has to be noted that -(I)p al- may have other functions as well: for example, if -(I)p al-attaches to intransitive main verbs (all the examples I have encountered were unaccusatives), the construction expresses that the subject undergoes a change of state (Akbaba 2011: 55). One of the examples that Akbaba (2011: 55) offers is quoted in (i).
}

(i) табан-ьы қыз-ыли ал-ван Рысул [...] (Akbaba 2011: 55)

sole-POSS.3 burn-IP LV-NF Rïswl

'Rysul, whose sole got burnt $[\ldots]$ '...

Note that the generalizations I make here only apply to the -(I)p al-constructions if they are used for expressing benefactivitiy. I leave the other - I think, rather rare - usages for further research.

${ }^{18}$ The position of Benefactive constructions -(I)p al- and -(I)p ber-also explains the fact that there are a lot of cases when the main verb + -(I)p al-/-(I)p ber-construction seem to form one lexical item. In (i) and (ii) two examples are offered. (Note that this list may as well be much longer. For instance, many from the list Akbaba (2011: 49) gives may belong here.)

cam-bin arsell-IP LV.B'to purchase' біл-іп алknow-IP LV.B'to get to know, learn'

${ }^{19}$ All the examples below that are followed by numbers come from Questionnaire 1 . The numbers following the sentences indicate how many native speakers (out of a total of eight speakers) marked the sentence as grammatical. For more information see the questionnaire and its description it in the appendix. 
(14) Қазаз-ва жаз-ып бер-іп кет-ті. 8/8

paper-DAT write-IP LV.B-IP LV.C-PAST.3

'(S)he wrote it down on the paper. (for someone)'

(15) *Газет әкел-іп жүр-in бер-ген. 8/0

newspaper bring-IP LV.CONT-IP LV.B-PERF.3

Intended: 'He was bringing the newspaper (to someone).'

(16) ? Газет әкел-іп бер-in отыр-ван. 8/4 (1 QM) $)^{20}$ newspaper bring-IP LV.B-IP LV.CONT-PERF.3

'He was bringing the newspaper (to someone).'

The Benefactive -(I)p al- and -(I)p ber-cannot embed negation, which indicates that Benefactives can only embed VoiceP (unlike the other "verb-CV verb" constructions, as soon it will be addressed). In (17)-(20) the distribution of the negative suffix with -(I)p al- / -(I)p ber- is presented. -(I)p al- and -(I)p ber-cannot embed a NegP, as the ungrammatical examples (18) and (20) indicate. ${ }^{21}$ The negative head $-M A$ - must come after $-(I) p$ al- or -(I)p ber-, as in the grammatical (17) and (19).

Нәзір бұл өлеңу-дер-дің, мавына-сын

неге сұра-п ал-ма-ды екен? (РC.)

Näzir this poem-PL-GEN meaning-POSS.3.ACC why ask-IP LV.B-NEG-PAST.3 COP.EVID '(I wonder) Why Nazir didn't ask the meaning of these poems?'

(18) *Біз сол кітапхана-дан қзолжазба-лар көшір-мей ал-ды-ку. 8/0 we that library-ABL manuscript-PL copy-MAY LV.B-PAST-PL1 Intended: 'We did not copy manuscripts from that library.'

(19) Патша бұл іс-ті шеш-іп бер-ме-дi. (РС.) sultan this matter-ACC solve-IP LV.B-NEG-PAST. 3

'The sultan didn't solve this issue.'

\footnotetext{
${ }^{20}$ Only four speakers accepted this sentence, but note that the same complex predicate (äkelip berip otïrgan) can be found in Kazakh texts.

${ }^{21}$ Note that $-M A y$ is the negative allomorph of $-(I) p$ and $-y / A$.
} 
(20) *Патша бұл іс-ті шеш-пей бер-ді. 8/0 (1 QM)

sultan this matter-ACC solve-MAY LV.B-PAST.3

Intended: 'The sultan didn't solve this issue.'

\subsubsection{Completive constructions}

The next group is the Completive constructions. -(I)p ket- may express that the event came about completely, and suddenly and/or swiftly (cf. (21)). ${ }^{22}$ If it joins an emotive main verb (e.g. qorq- 'to be afraid', qwan- 'to be delighted') the -(I)p ket- expresses that getting into that emotive state happens very intensively (cf. (22)). (Akbaba 2011: 171-180, Ysqaqov 1974: 267-268)

Түн-де біз-ді жау шау-ып кет-mi. (KV, KQMM)

night-LOC we-ACC enemy attack-IP LV.C-PAST.3

'The enemy attacked us during the night.'

қ̧орқ̧-ып кет-mi

be.afraid-IP LV.C-PAST.3

'(s)he got very afraid'

-(I)p qal- joins only intransitive verbs, and it has slightly different meanings depending whether it attaches to a telic or an atelic main verb. If it joins an atelic verb, its meaning is 'doing that activity for a long period of time' (cf. (23)) (Akbaba 2011: 195-196), while with telic verbs it expresses that the final stage was reached swiftly (see (24)). (Akbaba 2011: 194199, Oralbaeva 1979: 167-168, Ysqaqov 1974: 267)

қ̧ара-n қал- ды

look-IP LV.C-PAST. 3

'(s)he was staring; (s)he was in the state of staring (at something) for a long time'

\footnotetext{
${ }^{22}$ It is noteworthy that -(I)p ket- is often used with main verbs expressing motion (e.g. žönel- 'to go away', öt'to pass, pass by', žür- 'to walk'). With these main verbs it expresses that there is a motion away from the centre (e.g. žürip ket- 'to walk away'). (Akbaba 2011: 171-180) I assume that in this usage the inflecting verbs are not light verbs (possibly they form a serial verb construction).
} 
goat-GEN blood-POSS. 3 come.to.an.end-IP LV.C-PAST. 3

'The goat's blood ran out.'

-(I)p žiber-expresses that the event comes about completely, and unexpectedly and/or quickly (Akbaba 2011: 131-138, Oralbaeva 1979: 167-168, Ysqaqov 1974: 270) .

(25) Су-ва бат-қ̧ан соң, құдай таzы да тірілт-іп жнібер-дi. (KV, TTBS) water-DAT sink-NF after god again too revive-IP LV.C-PAST.3

'After (I) sank into the water, god revived (me) again.'

The semantics of -(I)p tasta- is very similar to -(I)p žiber-. It marks events that are carried out completely and quickly, without hesitation (Akbaba 2011: 246-247, Oralbaeva 1979: 167168, Ysqaqov 1974: 268). Note that -(I)p tasta- can only join main verbs that have an agentive external argument.

(26) Мен даң̧гыра соқ-қ̧ан-да, қыырық есік-ті бекіт-іп таста-ң̧дар. (KV, KQMM)

I drum hit-NF-LOC forty door-ACC close-IP LV.C-IMP.PL2

'When I hit the drum, close the forty doors.'

Completive "verb-CV verb" constructions follow the Benefactive ones, that is, they can embed -(I)p al- and -(I)p ber-. An example has already been given above with the construction -(I)p ket-, and two more are offered with -(I)p qal- (in (27)) and -(I)p tasta- (in (29)). The following examples too show that we get an ill-formed sentence if we invert the Benefactive and the Completive (cf. the ungrammatical (28) and (30) and the grammatical (27) and (29)).

(27) ?Біз-дің құызметкер-лер оны Қызылорда-да we-GEN personnel-PL (s)he.ACC Qïzïlorda-LOC пойыз-дан түс-ір-іп ал-ыn қал-дbl. 8/5 train-ABL get.off-CAUS-IP LV.B-IP LV.C-PAST.3 'Our personnel forced him/her to get off the train in Kyzylorda. ' 
(28) *Біз-дің құызметкер-лер оны Қызылорда-да

we-GEN personnel-PL (s)he.ACC Qïzïlorda-LOC

пойыз-дан түс-ір-іп қал-ып ал-дыл. 8/0

train-ABL get.off-CAUS-IP LV.C-IP LV.B-PAST.3

Intended: 'Our personnel forced him/her to get off the train in Kyzylorda. '

(29) Шарлиз Терон шаш-ылн тықырла-п ал-ыn macma-ды. 8/7

Charlize Theron hair-POSS.3.ACC cut.sg.short-IP LV.B-IP LV.C-PAST.3

'Charlize Theron cut her hair short.'

(30) *Шарлиз Терон шаш-ьын тықыьрла-п таста-п ал-ды. 8/0

Charlize Theron hair-POSS.3.ACC cut.sg.short-IP LV.C-IP LV.B-PAST.3

Intended: 'Charlize Theron cut her hair short.'

In contrast to -(I)p al- and -(I)p ber-, Completive constructions can embed bigger structure than VoiceP: they can, for one, embed the "verb-CV verb" constructions with -(I)p $a l$ - and -(I)p ber-. They can also embed NegP. Remember that in case of -(I)p al- and -(I)p ber- the negation could only follow the inflecting verb. Completives, however, can embed NegPs. This is shown with -(I)p qal-, -(I)p žiber- and -(I)p tasta- in examples (31), (33) and (35), respectively. In these examples the negative allomorph of $-(I) p$ (i.e. $-M A y)$ precedes the inflecting verb. On the other hand, the negation can also follow the inflecting verb, as in (32), (34) and (36). The two strategies are not interchangeable: there is a scope difference between them. If the Completive construction follows the negation, it expresses that the subject got to a state of not-doing something. If the inflecting verb is followed by the negation, it expresses that neither of the subevents took place, i.e. neither the event of the main verb nor its completion.

Өмірбек Бек-ті таны-май қал-ды. 8/8

Ömirbek Bek-ACC recognize-MAY LV.C-PAST.3

'Ömirbek didn't recognize Bek.' (Lit.: 'Ömirbek was in/got into the state of not recognizing Bek.’) 
(32) Қала биліг-i де құара-п қал-ма-ды. 8/6

city authority-CM too watch-IP LV.C-NEG-PAST.3

'The city government didn't just sit back.' (Lit.: 'The city government didn't remain watching.')

(33) Олар дым бер-мей жжібер-ді. 8/5 (1 QM)

these voice give-MAY LV.C-PAST.3

'They didn't give a sound.' (Lit.: 'Suddenly they became such that doesn't give a sound.')

(34) Құұдай оны тавы да тірілт-іп жібер-ме-ді. 8/6

god (s)he.ACC again too revive-IP LV.C-NEG-PAST.3

'God didn't resurrect him/her one more time.'

(35) Төреші бұлгол-ды есеп-ке ал-май таста-ды. 8/6 referee this goal-ACC account-DAT take-MAY LV.C-PAST.3

'The referee didn't validate this the goal.'

(36) Есік-ті бекіт-іп таста-ма-нудар. 8/7

door-ACC close-IP LV.C-NEG-IMP.PL2

'Do not close the door!' 


\subsubsection{Manner constructions}

$-y / A$ qoy- conveys that the event occurs suddenly, it is carried out quickly and/or with ease ${ }^{23}$ (Akbaba 2011: 206-211, Ysqaqov 1974: 268). An example is offered in (37).

\section{[...] бала патша ииша-ның аузын}

child padishah bottle-GEN mouth.POSS.3.ACC

бас бармад-ыл-мен бас-а қой-ылтты $[\ldots](\mathrm{KV}, \mathrm{BP})$

head finger-POSS.3-INSTR push-A LV.M-EVID.3

'... the child padishah covered the mouth of the bottle with his thumb quickly...'

In case of $-y / A$ sal- the action is performed neglectfully, without paying attention ${ }^{24}$ (Akbaba 2011: 231-233, Ysqaqov 1974: 267).

Керек бол-ар деп,

necessary become-FUT.3 DISC.PART

біраз барқуыт ал-а сал-дыл-м. (Akbaba 2011: 232) $)^{25}$

some velvet buy-A LV.M-PAST.SG1

'(Because in the future) we might need it, I bought some velvet (fabric).' (Implies that the fabric was bought without paying attention, for example, to the quality.)

Manner constructions can embed Completives (and consequently Benefactives). In examples (39) and (40) $-y / A$ sal- and $-y / A$ qoy- follow the Completive, which is marked by -(I)p žiber- in (39) and by -(I)p ket- in (40). Sentence (41) illustrates that the order of Completive and Manner constructions is not interchangeable.

\footnotetext{
${ }^{23}-y /$ A qoy- is often used with the imperative (Abish 2014: 26-27). This might be the reason why Akbaba (2011: 207) distinguishes a "request" meaning too. (Note that both descriptively and theoretically it is an unaddressed question why/when certain "verb-CV verb" constructions occur together with certain modal or aspectual morphemes.)

${ }^{24}$ Akbaba (2011: 231-233) claims that $-y / A$ sal- can also express that the action is carried out quickly. However, this meaning only occurs in the $-y / A$ sala or $-y / A$ salip constructions. As I will argue below $-y / A$ sala and $-y / A$ salip have to be treated separately. Thus I do not attribute "quickness" meaning to the $-y / A$ sal- constructions.

${ }^{25}$ For the sake of uniformity, the examples from Akbaba (2011) are given in the Cyrillic script. (Akbaba transliterates the Kazakh examples based on the Turkish orthography. Cf. Appendix: Some notes on the transliteration of Kazakh examples.)
} 
Бала-сын ат-қ̧а отыр-zыз-ып жсібер-е сал-ды. (NET-AÄ)

child-POSS.3.ACC horse-DAT sit-CAUS-IP LV.C-A LV.M-PAST.3

'(S)he put his/her child on a horse [without any care/ without paying attention].'

(40) Барльққ нарсе өзгер-іп кет-е қояды. 8/5 (1 QM, 1 NA)

every thing change-IP LV.C-A LV.M.PRES.3

'Everything has changed quickly.'

(41) *Барльқ нәрсе өзгер-е қой-ып кет-еді. 8/0

every thing change-A LV.M-IP LV.C-PRES.3

Intended: 'Everything has changed quickly.'

It is not a surprise that Manner constructions can embed NegP-s, moreover, that the negation can also follow them. As we saw above, there is a scope difference between "low" and "high" negation. Examples (42) and (43) illustrate this: in (42) the negation precedes the Manner construction, and the sentence expresses that the event (the 'leaving alone') took place quickly and/or with ease. In (43) the negation follows the inflecting verb, emphasising that the event does not take place quickly, i.e. it scopes over $-y / A$ qoy- and the main event too.

(42) Қизат-тың соң-ьнын

$$
\text { қ̧ал-май қой-са-м керек, }
$$

Qïyzat-GEN end-POSS.3.ABL stay-MAY LV.M-COND-SG1 must мені мін-гіз-іп ал-ыл кет-ті. (M/N-GSB)

I.ACC get.on-CAUS-CV take-IP leave-PAST.3

'I probably wasn't leaving Kiyzat alone, so he seated me (on the cart) and took me away.'

Жұмса-ван-ына бар-а қой-ма-са-н, order-NF-POSS.3.DAT go-A LV.M-NEG-COND-SG2 strike-NF-LOC қ̧ан-ылмыз-ды, соқ̧-қ̧ан-да сөл-іміз-ді ал-ады. (Akbaba 2011: 211) blood-POSS.PL1-ACC hit-NF-LOC vitality-POSS.PL1-ACC take-PRES.3 'If you don't go (immediately) when he orders it, then when he strikes down, he'll take our blood and vigour.' 


\subsubsection{Continuous constructions}

-(I)p žat-, -(I)p žür-, -(I)p oẗ̈r-, -(I)p tur- are Continuous constructions. The main verb determines which inflecting verb may attach to it depending on in which body position (i.e. lying, walking, sitting or standing) the main event is being performed. (But there are some other factors too, see Kažbulatova 2011: 87-88.) Continuous constructions follow all the above-mentioned "verb-CV verb" constructions. In (44) the Continuous -(I)p žat-embeds the Completive -(I)p qal-.

(44) Қатар-дан шыв-ып қал-ып жсат-ққан

line-ABL leave-IP LV.C-IP LV.CONT-NF

спортсмен-дер да жетерлік. 8/6 (1 QM)

athlete-PL too sufficient

'The athletes who don't excel are sufficient.'

Continuous constructions can also embed NegP (as in (45) and (47)), and they too could be followed by a NegP (as in (46) and (48)). The meanings depending on the position of the NegP are slightly different, as shown in the following examples.

[Сенің өмір-ің-де өзгеріс-тер

[you.GEN life-POSS.SG2-LOC change-PL

бол-май жжат-қ̧ан-ьı] біл-е-мін. (РС.)

COP-MAY LV.CONT-NF-POSS.3]ACC know-PRES-SG1

'I know that there are no changes happening in your life. [I have been expecting some changes to happen.]'

(46) [Сенің өмір-ің-де өзгеріс-тер

[you.GEN life-POSS.SG2-LOC change-PL

бол-ып ж⿻ат-па-ван-ын] біл-е-мін. (РС.)

COP-IP LV.CONT-NEG-NF-POSS.3]ACC know-PRES-SG1

'I know that there are no changes happening in your life.' 
'No changes are happening in your life. [The speaker has been expecting some changes to happen.]'

(48) Сенің өмір-іңу-де өзгеріс-тер бол-ып ж⿻ат-қан ж⿻қ. (РС.) you.GEN life-POSS.SG2-LOC change-PL COP-IP LV.CONT-NF not.existing 'No changes are happening in your life.'

\subsubsection{Notes on complex "verb-CV verb" constructions}

The constructions I call complex "verb-CV verb" constructions include two "inflecting verbs", but these constructions, as soon it will become clear, are not identical with the above mentioned usage when two different types of "verb-CV verb" constructions are used following each other (e.g. Benefactive + Completive). Some complex "verb-CV verb" constructions are given in (49). Unless indicated otherwise, their meanings are given based on Oralbaeva (1979: 80-81) and QG: 541.

(49) Complex "verb-CV verb" constructions in Kazakh

-(I) $p \kappa е n^{26} ж і б е р-$ 'the event is carried out with force and quickly'

-(I)p кеп кет- 'the event occurs unexpectedly and swiftly'

-(I) $р$ кеп қ̧ал- 'the event happens very fast and is carried out with force'

-(I) $р$ кеп бер- 'the event happens very fast and is carried out with force'

-(I)р қоя бер- 'the event is unexpected and comes to a end quickly'

-(I)р сала бер- 'the event starts out slowly'

-(I)р жүре бер- 'the event starts out without any hindering, swiftly'

-(I)p келе жат- '[continuous]'

-(I)p бара жат- '[continuous]'

-(I)р болып қ̧ал- 'the event will come to an end soon'

-(I)p беріп жібер- 'the event is carried out completely and with determination' (Akbaba 2011: 137)

-(I)p жambln aл- 'the event goes on for a long time' (Akbaba 2011: 55) ${ }^{27}$

\footnotetext{
${ }^{26}$ kep is the $-(I) p$-marked form of the verb kel- 'to come'. That is, kelip > kep.
} 
I assume that these complex constructions function as one unit, i.e. they do not consist of two independent "verb-CV verb" constructions. This can be accounted for if we take a closer look at one of the functions that suffix $-(I) p$ can fulfil.

The suffix $-(I) p$ can also from "complex" lexical items. I have not encountered with the description of this property of $-(I) p$ in any of the Kazakh grammars, but it certainly exists. Notice that in examples (50) through (53), two verbs are conjoined with $-(I) p$, and the two verbs refer to only one event (and not to two separate events, as it would be expected if the -(I)p's function was converbial). The meaning of these "complex" verbs are not compositional (that is, it cannot be deduced from the meanings of the verbs it consists of). Thus for instance, in (50) the first verb, oyla- means 'to think' and the second verb tap- is 'to find', and they are joined with the morpheme $-(I) p$. If $-(I) p$ was a converb morpheme in this example, the meaning would be 'to find something by thinking', but the "complex" verb oylap tap- means specifically 'to invent (e.g. a new object, procedure etc.)'.

(50) ойла-n man-

think-IP find-

'to invent'

(51) сипала-п жүгір-

caress-IP take.a.look-

'to feel (the surroundings) for (something)'

бар-bin $ш ы$ қ-

go-IP leave-

'to visit someone'

(53) ойна-n-күл- (written with a hyphen: ойнап-күл-)

play-IP laugh-

'to have a good time, to enjoy herself/himself'

\footnotetext{
${ }^{27}$ Note that Akbaba (2011) gives several more complex forms not listed here. It would need a thorough investigation to prove that all of them are indeed true "verb-CV verb" constructions.
} 
I assume that the same thing happens in case of complex "verb-CV verb" constructions as in the verbs in (49), that is, $-(I) p$ forms a complex infecting verb. This is supported by the fact that the meaning of these complex "verb-CV verb" constructions is not the same as the individual meanings of the "verb-CV verb" constructions they seemingly include. Moreover, in some of these complex "verb-CV verb" constructions the segments are not used as inflecting verbs independently. For instance, in -(I)p kele žat- and -(I)p bara žat- the $-y / A$ žatsegment is not used as a "verb-CV verb" construction (Oralbaeva 1979: 61).

This is important for us, because some of the complex "verb-CV verb" constructions seem to violate the above described ordering (i.e. Benefactive - Completive - Manner Continuous). For example, in -(I)p žatïp al- the -(I)p žat- segment (if used independently, a Continuous construction) is followed by the Benefactive $-(I) p$ al-. This would violate our above-established ordering, since the Continuous would be followed by the Benefactive form. But this is not the case, because -(I)p žatïp al-should be considered as one unit.

\subsubsection{Interim summary}

So far it has been established that "verb-CV verb" constructions, although they consist of a converb-marked verb form, are unlike converb clauses. It was shown that "verb-CV verb" constructions form groups such as Benefactive (-(I)p al-, -(I)p ber-), Completive (-(I)p qal-, -(I)p žiber-, -(I)p tasta-, -(I)p ket-), Manner (-y/A qoy-, -y/A sal-) or Continuous (-(I)p žat-, -(I)p žür-, -(I)p otïr-, -(I)p tur-). (Note that it is possible that future research will reveal that there are more such groups.) We also made the novel observation that these groups are strictly ordered, as given in (54).

(54) Order of the "verb-CV verb" groups

\begin{tabular}{|l|l|l|l|l|}
\hline verb & Benefactive & Completive & Manner & Continuous \\
\hline
\end{tabular}

The Negation Phrase's distribution was also discussed with the "verb-CV verb" constructions: we found that NegP cannot precede the Benefactive, it can only follow it, but in case of all the other groups the negation can either precede or follow them. 


\subsubsection{The syntax of "verb-CV verb" constructions}

In what follows, I attempt to give a syntactic analysis of the "verb-CV verb" constructions. I am going to define the category of the inflecting verbs and give an analysis of the status of the "converb morpheme" (following Meral 2012, providing some additional evidence in favour of his analysis).

\subsubsection{Inflecting verbs are light verbs}

As far as I am aware, Bowern (2004: 44) was the first to propose that inflecting verbs in the "verb-CV verb" constructions are light verbs and not auxiliaries. Following Miriam Butt, she assumes that light verbs do not have defective paradigms (in contrast to auxiliaries) and they always correspond to a heavy verb in that language. In these terms, the inflecting verbs in the "verb-CV verb" constructions are indeed light verbs, and not auxiliaries.

At first glance, the light verb analysis seems to be a good fit for the Kazakh constructions in question. But as it will be shown below, there are some difficulties and details that need to be made clear.

I shall begin with the general characteristics of light verbs. Light verbs combine with some kind of non-verbal element (a noun, an adjective, a postpositional phrase) to form a complex predicate. In the Kazakh constructions in question two (or more) verbs are combined, however, this does not necessarily pose a problem, since the verb preceding the inflecting verb always bears a "converb morpheme", thus it is deverbal. ${ }^{28}$

Light verbs are thought to have less semantic content than their heavy counterparts ${ }^{29}$ (Karimi 2013: 2). Naturally, this also holds for the Kazakh constructions under investigation: for instance, in (3) or in (4) the inflecting verb al- does not express actual 'giving'.

Moreover, Butt argues that light verb constructions are monoclausal (Butt \& Ramchand 2005: 126-132, Butt 2010: 8-10, Butt \& Lahiri 2013: 8-9). There can be no doubt that Kazakh inflecting verbs are not predicates of clauses different from the clause of the main verb.

\footnotetext{
${ }^{28}$ Butt (2010: 4) argues that V-V type of light verb constructions are also possible (or at least, they are possible in Urdu). However, note that diachronically the inflecting verbs in Urdu light verb constructions were combined with a "gerund" morpheme, which is still present in modern Bengali (Butt \& Lahiri 2013: 8).

${ }^{29}$ Butt (2010: 15) claims that it is the "central characteristic" of the light verbs that they are form identical with a heavy verb in a given language. (In fact, Butt makes this an important criteria distinguishing light verbs and auxiliaries.)
} 
In Persian light verbs are also responsible for adding certain semantic notions to the predication (Karimi 2013: 2), such as agentivity/causativity, eventiveness, duration (Folli et al. 2005: 1374-1379, among other authors), but according to some accounts light verbs can express completion, inception, benefaction, forcefulness and suddenness (see Karimi 2013: 2, also Butt 2010: 4, $14^{30}$ ). This, too, seems to hold for the Kazakh constructions.

In what follows, first I am going to discuss the complex predicates that unquestionably include a light verb (for the time being, I am going to refer to them as "true" light verbs), and then I will turn to the "verb-CV verb" constructions, and consider the possibility of analyzing them as light verb constructions, although a different type from the "true" light verbs.

\subsubsection{1 "True" light verbs}

There are complex predicate constructions in Kazakh that include the "true" light verbs $e t$ - or bol-. As a heavy verb bol- means 'to become', et- is rarely used as a heavy verb, but if it is, it denotes a vague 'to do' meaning. (These light verbs are, for sure, very similar to their Turkish cognates $e t$ - and $o l$-. Cf. Key \& Tat (to appear).) It is noteworthy that there might be other "true" light verbs in Kazakh; for example, kör-, which as a heavy verb means 'to see', would be a good candidate (cf. žaqsï kör- 'like' (lit. 'good see'), žek kör- 'hate' ${ }^{31}$ ). Our goal here, however, is not to give a complete list (or thorough analysis) of the "true" Kazakh light verbs, only to point out some of their core properties. Below I list a few complex predicate constructions formed with the light verbs $e t$ - and bol-.

(55) A few illustrative examples for complex predicates including et- and bolaзаm em- 'to free, release'

азат бол- 'to get free, become free'

(азаm 'free')

әсер em- 'to influence, affect'

(әсер 'influence, effect')

\footnotetext{
${ }^{30}$ The page numbers in case of Butt 2010 refer to the page numbers as found in the online PDF-format of the paper. (Cf. Bibliography.)

${ }^{31}$ The word žek is rarely used on its own. Its Old Turkic etymon yek denoted a 'demon, devil' (Clauson 1972: 910).
} 
дайын еm- 'to prepare'

дайын бол- 'to be prepared'

(дайын 'ready, prepared')

ец̧бек ет- 'to work, give an effort'

(еңъбек 'toil')

рұқ̧сат em- 'to authorize, approve'

рұқссат бол- -DAT 'be authorized' (what is authorized bears the dative case)

(рұқссаm 'authorization')

Even from this short list, it is clear that there must be more subtypes among the Kazakh complex predicate constructions. (Notice, for instance, that the light verb et- can form unergative (eybek et-) and transitive (azat et-, äser et-, dayïn et-, ruqsat et-) verbs as well.) The Kazakh complex predicate constructions might be similar in this regard to Turkish, about which Key \& Tat (to appear) assume that there are at least four different types of complex predicates formed with the light verb et-.

These light verb constructions and the "verb-CV verb" type differ from each other in many important aspects, as it will be shown in 2.1.4.1.2 - 2.1.4.1.4.

\subsection{Embedded categories}

First of all, it is clear that "true" light verbs (such as et-, bol- along with some others) select for different categories than "verb-CV verb" constructions. The "true" light verbs are verbalizers that select for nouns (ruqsat 'authorization', enbek 'toil'), for adjectives (azat 'free', dayïn 'ready, prepared'), but they may select for postpositional phrases as well. In contrast, in "verb-CV verb" constructions the inflecting verb can only select for a verb phrase marked with the suffixes $-y / A,-(I) p$ or $-\dot{G} A l I$. 


\subsection{Introducing external arguments}

"True" light verbs determine the external argument of the predicate (cf. Folli et al. 2005: 1375-1378). To illustrate this with an example, consider the above mentioned complex predicates azat et- 'to free, release' and azat bol- 'to get free, become freed'. The first one is a transitive verb, hence it has an external argument (an agent). (See example (56), where the external argument is Kürd žasag̈ 'Kurdish forces'.)

$$
\begin{aligned}
& \text { Күрд жасад-ь Кобани-ді ИМ тоб-ьлан азат ет-ті. (NET-AZAT) } \\
& \text { Kurdish army-CM Kobanị-ACC IS group-CM.ABL free LV-PAST.3 } \\
& \text { 'The Kurdish forces freed Kobani from the ISIS groups.' }
\end{aligned}
$$

The inchoative azat bol- has no external argument. According to a Minimalist Program style approach, the only available noun phrase, in this case the internal argument Kobani 'Kobani', will move to the subject position.

\section{Кобани азат бол-дыл. (РС.)}

Kobani free LV-PAST.3

'Kobani became free.'

It is obvious that the non-verbal element (in this case the adjective azat 'free') cannot have an impact on the external argument. (56) and (57) contain the same non-verbal element (azat 'free'), still the first sentence has an external argument (the agentive 'Kurdish forces'), the second sentence does not. Hence, what determines the presence or absence of an external predicate must be the light verb: if et-is used, there is an external argument, if bol-, there is no external argument. ${ }^{32}$ Based on the analysis of Turkish put forth in Key \& Tat (to appear) and on Folli's and her co-authors' analysis of Persian (Folli et al. 2013: 1375), I propose the following representations for the Kazakh complex predicates in (56) and (57). (The abbreviation AP stands for Adjectival Phrase, which functions as a small clause, as put forth in Folli et al. 2013: 1374.) In (58) the light verb et-, realizing the v-Cause syntactic node, is

\footnotetext{
${ }^{32}$ It has to be noted that there might be cases when et- is not responsible for introducing an external argument. Nevertheless, in other cases (such as in the above examples) it can, in contrast to the "verb $+\mathrm{CV}$ verb" constructions.
} 
responsible for introducing the external argument 'Kurdish forces'. ${ }^{33}$ As shown in (59), vBecome cannot introduce an external argument.

(58) azat et- 'to free, release'

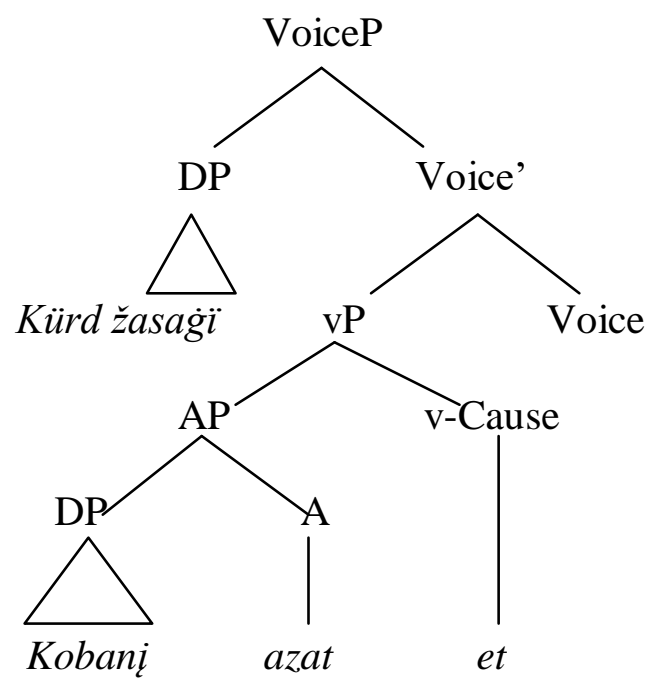

(70) azat bol- 'to get free, become free'

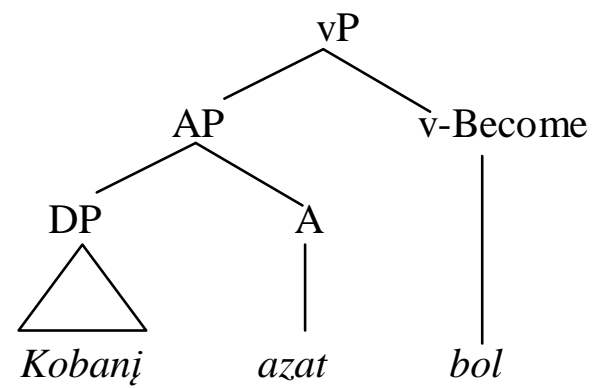

In contrast to the "true" light verbs, none of the inflecting verbs in the Kazakh "verb-CV verb" constructions have any kind of influence on the external argument. (60) and (61) include the construction -(I)p ket-, which expresses completeness, i.e. that the action/change of state was carried out/came about completely. -(I)p otïr- in (62) and (63) expresses continuity. (60) and (62) have no external argument (the subjects of 'dying completely' and 'be baffled' are nonagents). In contrast, there is an external argument in (61) and (63). So it is clear that $-(I) p$ ketand -(I)p otïr- do not determine the presence or absence of external argument, since they

\footnotetext{
${ }^{33}$ v-Cause allows the Voice Phrase to be present, and the external argument gets introduced in its specifier.
} 
could be included in examples where there was an external argument ((61) and (63)), and in examples where there was not ((60) and (62)).

(60) Тұншыз-ып өл-іп кет-mi. (Akbaba 2011: 172)

suffocate-CV die-IP LV.C-PAST.3

'(S)he choked to death.' Lit.: 'Having suffocated, (s)he died (completely).'

(61) Мына альс-тан кел-ген мейман-дар-ды абайсызда

this far-ABL come-NF quest-PL-ACC unexpectedly

тау-дыңң жыртқыши-ы талқанда-п кет-пе-сін. [...] (Akbaba 2011: 174)

mountain-GEN beast-POSS.3 tear.to.pieces-IP LV.C-NEG-IMP.3

'(Let it not happen that) the beasts of the mountain unexpectedly tear these guests who come from far away into pieces.'

(62) Патма дауль түйе-ні қайсы-сына

padishah debated camel-ACC which-POSS.3.DAT

бұйыр-ып бер-у-ді біл-мей таң-тамаша бол-ып отыр-zан-да,

order-IP LV.B-NNF-ACC know-NEG.CV amazed COP-IP LV.CONT-NF-LOC

тавы да бір жас бала тұр-ыл: [...] (KV, ВР)

also too one young child stand-CV $[\ldots]$

'When the padishah was (being) amazed, not knowing to which one to give the debated camel, a young boy stood up [and said...]'

(63) Ойбай, құнақ-тар-ыңฺ осындай сөз-дер айт-ып отыр. (KV, TÜU)

Oh quest-PL-POSS.SG2 such word-PL say-IP LV.CONT.PRES.3

'Oh, what kind of words are your guests saying!'

Thus the verbs ket- and otïr- (as in -(I)p ket- and -(I)p otïr-) do not introduce external arguments. This claim can be extended to all inflecting verbs in "verb-CV verb" constructions.

This said, it has to be mentioned that while the inflecting verbs in "verb-CV verb" constructions do not introduce arguments, some of them are sensitive to argument structure. For instance, the inflecting verb qal- in -(I)p qal- (expressing completeness) can only select 
for intransitive verbs (an unaccusative and an unergative example can be seen in (64) and $(65))$.

(64) құла-п қ̧ал-ды (Ysqaqov 1974: 267)

fall-IP LV.C-PAST.3

'(s)he fell'

(65) кет-іn қ̧ал-дbl (Ysqaqov 1974: 267)

leave-IP LV.C-PAST.3

'(s)he left'

However, -(I)p qal-cannot select for transitives, illustrated with the infelicitous example in (66).

(66) *Темір қ̧ол-ьıн

қар-ып қал-ды. (Oralbaeva 1979: 168)

iron hand-POSS.3.ACC burn-IP LV.C-PAST.3

Intended: 'The iron burned his/her hand.'

Moreover, the inflecting verb tasta- in -(I)p tasta- (expressing completeness) selects only for main verbs with agentive subjects, illustrated in (67), where those who roll away the stone must be agents.

(67) [...] mac-mbl aydap-bin macma-n, бір тегісте-ген stone-ACC roll.away-IP LV.C-CV one level-NF жер-ге кір-іп жүр-е бер-дi. (KV, QP) place-DAT enter-IP walk-A LV-PAST.3 '... after they rolled away the stone, they entered a place (whose ground) was levelled.'

The following sentence is ill-formed, because the subject temir 'iron' is not an agent. (If we wanted to use a completive construction in this sentence, we could have used -(I)p žiber- or -(I)p tüs- (cf. Oralbaeva 1979: 168).) 


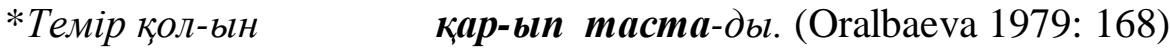

iron hand-POSS.3.ACC burn-IP LV.C-PAST.3

Intended: 'The iron burned his/her hand.'

\subsection{Position}

The selectional properties and the capability of introducing external arguments are closely related to the position of "true" light verbs and inflecting verbs in "verb-CV verb" constructions. Even if we assume that the "true" light verb et- realizes different syntactic positions in Kazakh, too, similarly to Turkish (cf. Key \& Tat (to appear)), we have to accept that it is always inside (projecting) vP. However, inflecting verbs clearly embed the vP, rather than being situated inside it. This latter claim is supported by the fact that inflecting verbs in the "verb-CV verb" constructions have no influence over the argument structure of the verb phrase. The explanation for this must be that these constructions select for VoiceP-s or vP-s, which already include (or do not include) an external argument.

\subsubsection{5 vP-selecting light verbs}

Having established that "true" light verbs are different from inflecting verbs in "verb-CV verb" constructions, we can turn to the analysis of the latter group. I am going to argue that inflecting verbs in "verb-CV verb" constructions are light verbs, but different from those found in the "true" light verb constructions (i.e. et- and bol-). What supports this approach?

First of all, these constructions are situated below the Inflection position (see Table 1 in the Appendix), that is, they can be followed by morphemes belonging to the Inflection slot. (See examples below.) This means that "verb-CV verb" constructions cannot be "regular" aspectual, modal etc. heads.

Moreover, it is significant that the main verb and the inflecting verb do not denote separate events. The mere function of the inflecting verb is to specify the main event (in terms of completedness, continuity, manner etc.). Butt \& Ramchand (2005) propose for the similar Urdu constructions that the inflecting verb indicates a subevent, being only a component forming the verb phrase (along with, for instance, the causing and the process subevents). Thus it would make sense to analyze the inflecting verbs in "verb-CV verb" constructions as 
light verbs. However, these light verbs have different properties than those that we called "true" light verbs (i.e. et- and bol-).

Firstly, these light verbs select for no smaller structure than $\mathrm{vP}$, in contrast to the "true" light verbs, which select for some kind of non-verbal element (e.g. Adjective Phrase, Noun Phrase etc.). Moreover, the strict order of these "verb-CV verb" constructions could be explained with assuming that $\mathrm{v}$-Benefactive selects for VoiceP, $\mathrm{v}-$ Manner selects for $\mathrm{v}_{\mathrm{Comp}} \mathrm{P}$ or for a smaller $\mathrm{v}_{\mathrm{Ben}} \mathrm{P}$ or VoiceP, and so forth. The tree in (69) illustrates this.

(69) Order of verbal functional categories above VoiceP

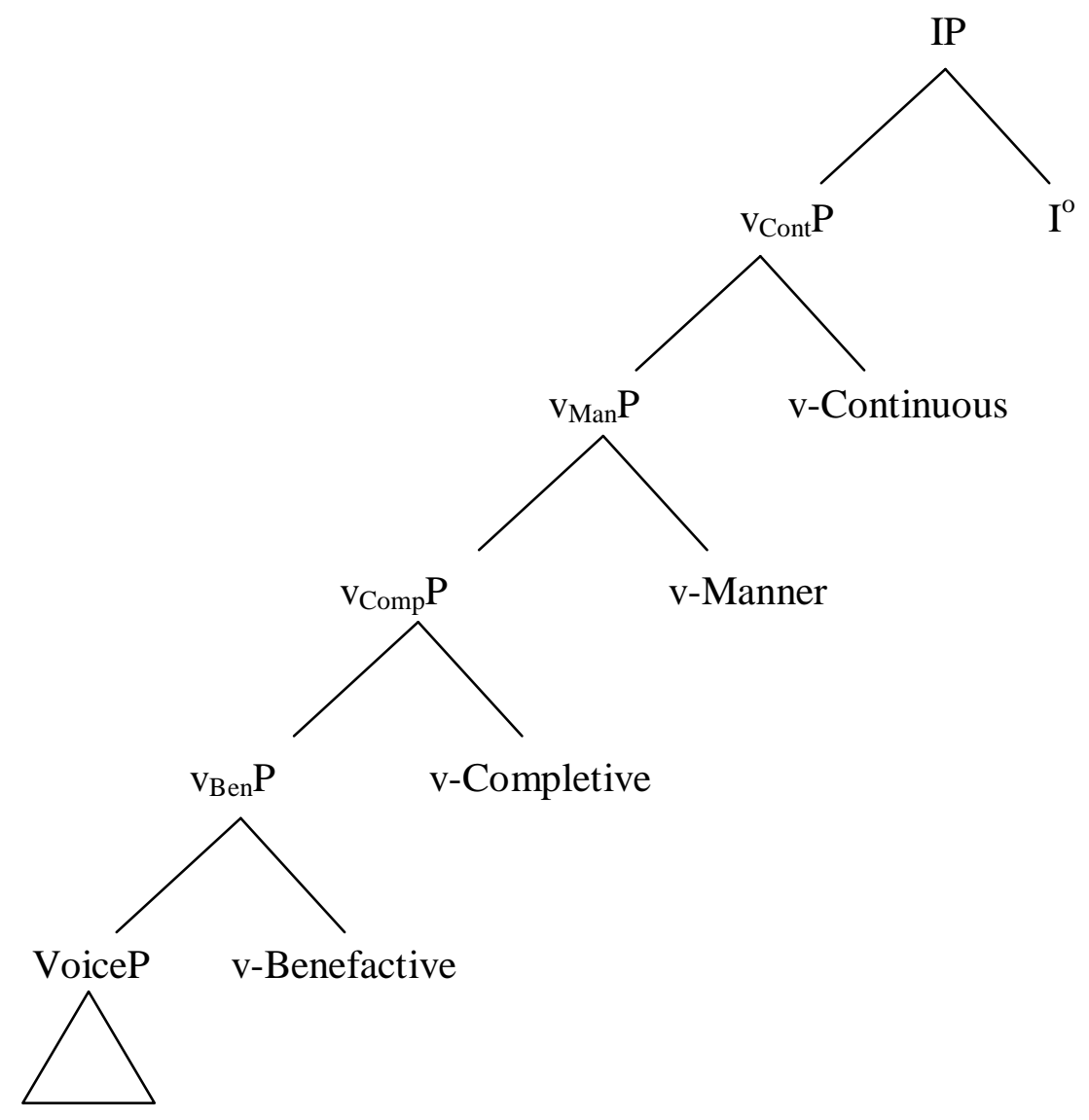

This account can also explain why the main verb and the inflecting verb (i.e. the high light verb) can be negated separately. Negation in Kazakh, apparently, selects for (any kind of) vP. Thus it can select for the "low" VoiceP, and for the "high" $\mathrm{v}_{\mathrm{Ben}} \mathrm{P}, \mathrm{v}_{\mathrm{Comp}} \mathrm{P}, \mathrm{v}_{\mathrm{Man}} \mathrm{P}, \mathrm{v}_{\mathrm{Cont}} \mathrm{P}$ as well. So negation (NegP) in Kazakh can select for the subevents separately. 


\subsubsection{2 "Converb morphemes" in "verb-CV verb" constructions}

The "converb morphemes" $-(I) p,-y / A$ and $-\dot{G} A l I$ (in "verb-CV verb" constructions) do not have the same syntactic status as the homonymous heads of adverbial clauses. This has already been argued for above.

I follow Meral (2012) in analyzing the "converb morphemes" in "verb-CV verb" constructions as dissociated morphemes. This means that these "converb morphemes" do not have an independent syntactic position, but they occupy one syntactic position with the high light verb. This could be considered as the violation of the principle according to which every morpheme corresponds to a syntactic position. (Meral 2012: 244-245) Meral formulates his hypothesis in Distributed Morphology ${ }^{34}$, a framework that allows morphemes that do not have a corresponding syntactic position. That is, dissociated morphemes are not added to the structure to match any syntactic node; they are added to a functional head to fulfil a wellformedness requirement. Meral (2012: 245-247) argues that in Kazakh "verb-CV verb" constructions (on the syntactic derivational level), the main verb combines with the inflecting verb, and the "converb morphemes" are added (in the Morphological Form) because of morphological well-formedness reasons.

The most important fact that supports this approach is the strict order of the "verb-CV verb" constructions (cf. the tree in (69)). If "converb morphemes" had their own syntactic status, any order would be possible. If high light verbs selected for a "converb"-marked phrase (e.g. -(I)p), it would be irrelevant what the high light verbs' relative order to each other is. So example (70) should be grammatical under an approach that attributes the "converb morpheme" an independent status. That is, if the light verb ket-selected for an -(I)p-headed clause, as well as the light verb ber-, they may follow each other the way it is shown in (70). However, this is not the case, hence high light verbs select not for "converb morpheme"marked phrases, but for different types of vP-s.

\section{(70) *Қаваз-ва жаз-ып кет-іп бер-ді. 8/0 paper-DAT write-IP LV.C-IP LV.B-PAST.3}

Intended: '(S)he wrote it down on the paper (for someone),'

\footnotetext{
${ }^{34}$ Distributed Morphology (DM), launched by Morris Halle and Alec Marantz, has its roots in Chomskyan generative grammar, but there are some characteristics that distinguish DM from, for instance, standard Minimalist Program. These are Syntax-all-the-way-down and Late Insertion. (For an accessible introduction to DM see Harley \& Noyer 1999 or Bobaljik's draft on DM (2011).)
} 
According to the DM approach, dissociated morphemes fulfil a well-formedness requirement. I propose that in this case, this requirement would be that light verbs have to attach to non-verbal items, and the sheer function of "converb morphemes" would be to convert the verb into a non-verbal item. ${ }^{35}$

\subsubsection{Verbal functional categories and their order in Kazakh}

We are going to turn now to the non-finite heads and their syntactic position. In 2.1.5.1 and 2.1.5.2 it will be shown that (all of the finite heads and) most of the non-finite heads can embed the above-described "high" light verbs. The only exception is the converb head $-y / A$ (and in certain cases -(I)p, which will be addressed in Chapter 3), which cannot embed any of the "verb-CV verb" constructions.

\subsubsection{Non-finite heads embedding high light verbs}

The table in (71) offers a summary of the finite and non-finite heads which can embed the above-discussed "high" light verbs. Data supporting this will be offered below the table.

\footnotetext{
${ }^{35}$ There are, naturally, some unresolved issues left. For instance, how come that depending on the "converb morpheme" (that would be a dissociated element) the same light verb could have different interpretations (and most probably different syntactic positions). We have to leave this question open for further research.
} 
(71) Verbal functional categories

\begin{tabular}{|c|c|c|c|c|c|}
\hline Verb & Benefactive & Completive & Manner & Continuous & Inflection \\
\hline & $\begin{array}{l}-(I) p \text { al- } \\
-(I) p \text { ber- }\end{array}$ & $\begin{array}{l}\text {-(I)p qal- } \\
-(I) p \text { žiber- } \\
-(I) p \text { tasta- } \\
-(I) p \text { ket- }\end{array}$ & $\begin{array}{l}-y / A \text { qoy- } \\
-y / A \text { sal- }\end{array}$ & $\begin{array}{l}-(I) p \text { žat- } \\
-(I) p \check{z} \ddot{u} r- \\
-(I) p \text { ot } ̈ \text { - } \\
-(I) p \text { tur- }\end{array}$ & $\begin{array}{l}\text { Finite: } \\
-D I \\
-\dot{G} A n \\
-(I) p(t I) \\
-y / A t I n \\
-(A) r \\
-A / y(d I) \\
-\dot{G} A y \\
-s A \\
\ldots \\
\text { Non-finite: } \\
-\dot{G} A n, \quad-y / A t I n, \quad-(A) r \\
\text { Converbs: } \quad-(I) p, \quad-M A y, \\
-\dot{G} A l I,-\dot{G} A s I n, \\
-M A y I n s \check{A}\end{array}$ \\
\hline
\end{tabular}

\begin{tabular}{|c|c|c|c|c|c|}
\hline Verb & Benefactive & Completive & Manner & Continuous & Nominalizer $^{36}$ \\
\hline & $\begin{array}{l}-(I) p \text { al- } \\
-(I) p \text { ber- }\end{array}$ & $\begin{array}{l}-(I) p \text { qal- } \\
-(I) p \text { žiber- } \\
-(I) p \text { tasta- } \\
-(I) p \text { ket- }\end{array}$ & $\begin{array}{l}-y / A \text { qoy- } \\
-y / A \text { sal- }\end{array}$ & $\begin{array}{l}-(I) p \check{z} a t- \\
-(I) p \check{z} \ddot{u} r- \\
-(I) p \text { ot } ̈ \ddot{r}- \\
-(I) p \text { tur- }\end{array}$ & $\begin{array}{l}-w \\
-M A q \\
-(I) s\end{array}$ \\
\hline
\end{tabular}

As shown in the table in (71) finite Inflection heads can embed high light verbs. In (72) the indefinite past Inflection head - $\dot{G} A n$ embeds the Continuous -(I)p tur- form.

(72) 1 күн-де кемінде 150 метре дейін су тартыл-ып тұр-zан. (M/N-AA)

1 day-LOC at.least 150 meter until water draw-IP LV.CONT-PERF.3

'The water drew back at least 150 meters daily.'

\footnotetext{
${ }^{36}$ I consider Inflection and Nominalizer heads distinct from each other, because Inflection heads contain aspectual information, while Nominalizers do not. For a detailed discussion see Chapter 4.
} 
In what follows it will be shown that the non-finite Inflection and Nominalizer heads (as in (72)) can indeed embed high light verbs. (We do not discuss them here in detail, because Chapter 3 is devoted to -(I)p, and Chapter 4 addresses -w, $-M A q,-(I) s,-\dot{G} A n,-y / A t I n,-(A) r-$ clauses. Thus the reader will be offered a description of these clauses in their respective chapters.)

In (73) the Nominalizer $-w$ embeds the Benefactive $-(I) p$ ber-, and the non-fintie Inflection head $-\dot{G} A n$ the Continuous $-(I) p$ otïr-. In (74) the Nominalizer $-w$ embeds the Continuous -(I)p otïr.

(73) Патша дауль түйе-ні құайсы-сына бұйыр-ып бер-у-дi padishah debated camel-ACC which-POSS.3.DAT order-IP LV.B-NNF-ACC біл-мей таңу-тамаша бол-ып отыр-ван-да, know-NEG.CV amazed COP-IP LV.CONT-NF-LOC тавы да бір жас бала тұр-ып: [...] (KV, ВР) also too one young child stand-CV [...]

'When the padishah was (being) amazed, not knowing to which one to give the debated camel, a young boy stood up [and said...]'

Ал арнайы мектеп-тер-де қ̧абілет-іне құрай and especially school-PL-LOC talent-POSS.3.DAT according ұстаз-дар бавыт-бав-дар бер-іп отыр-y-bl muic. (M/N-KMK) teacher-PL direction-PL give-IP LV.CONT-NNF-POSS.3 obliged 'And especially in schools the teachers have to be giving (him/her) guidance in accordance with his/her talents.'

In (75) the non-finite Inflection head $-\dot{G} A n$ embeds the Completive $-(I) p$ žiber-, in (76) the Continuous -(I)p otïr-. In (75) $-\dot{G} A n$ heads a relative clause, in (73) and (76) the $-\dot{G} A n$ clause is the complement of the locative semantic case. (For a detailed discussion see Chapter 4.)

Бұл кеше-гі шәрі-ден ку-ып жсібер-іл-ген қыз. (KV, KQMМ) this yesterday-ADJ city-ABL chase-IP LV.C-PASS-NF girl 'This is the girl from yesterday who was driven away from the city.' 
(76) Мола-ва бар-ыл, құран окьл-п, нан-ды же-п отыр-ван-да, cemetery-DAT go-CV, Koran read-CV, bread-ACC eat-IP LV.CONT-NF-LOC бір көр-дің тесіг-інен бір шал арбаңда-п шыд-ып кел-еді. (KV, ТВ) one tomb-GEN entrance-POSS.3.ABL one old.man limp-CV come.out-IP come-PRES.3 '(He) went to the cemetery and read the Koran, (and) when he was eating the bread, an old man came out from a tomb limping.'

The non-finite $-y /$ AtIn, in this case heading a relative clause, embeds the Continuous in (77).
Смагұл-дың ерліг- $i-$
бала-мызз-дың
бала-сына

Smagul-GEN heroism-POSS.3 child-POSS.SG1-GEN child-POSS.3.DAT

айт-ып отыр-атын ақ̧иқ̆ат. (M/N-MS)

tell-IP LV.CONT-NF truth

'Smagul's heroism is a truth that will/should be passed on to the children of our children.'

In (78) the converb head $-(I) p$ embeds the Benefactive $-(I) p$ al-, in (79) the Continuous -(I)p žür-.

(78) Cөümin, am-bıн, қару-жарав-blн mapm-bln aл-bln, so horse-POSs.3.ACC weapon-POSs.3.ACC pull-IP LV.B-CV Бек бет-і ау-ван жақ̆-қ̧а құарай жүр-іп кет-еді. (KV, AS)

Bek face-POSS. 3 move-NF side-DAT in.direction.of walk-IP leave-PRES.3 'After getting hold of his horse and weapons, Bek run away.'

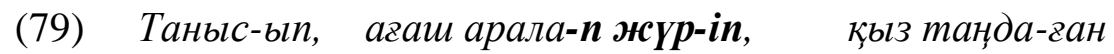
get.know-CV tree walk-IP LV.CONT-CV girl chose-NF жеміс-ін алвыз-ыпже-п жүр-еді. (KV, TÜU) fruit-POSS.3.ACC pick-CV eat-IP LV.CONT-PRES.3 'She was getting familiar (with the garden), she was walking amongst the trees, and was picking and eating the fruit she liked.' 
As it was demonstrated in Chapter 1, there are two different usages of -GAlI; it can mark the temporal and the purpose clauses. In both cases the converb head can embed high light verbs. In example (80), $-\dot{G} A l I^{1}$, which heads temporal clauses, embeds the Continuous light verb -(I)p otïr-.

[Ресей Оңтүстік Кавказ-ва устемдіг-ін жүргіз-іп отыр-валь] [Russia south Caucasus-DAT supremacy-POSS.3.ACC expand-IP LV.CONT-CV] бес жыл өт-ті. (NET-AZATR)

five year pass-PAST.3

'Five years passed since Russia has been expanding its supremacy over the South Caucasus (region).'

Sentence (81) exemplifies that the purposive $-\dot{G} A l I^{2}$, too, can embed high light verbs (in this particular example the Completive -(I)p qal-).

[Ерк-ім-дi биле-n, ес-ім-дi кетір-ген

[freedom-POSS.SG1-ACC rule-CV mind-POSS.3-ACC take-NF

ару-дыл бір көр-іп қал-zалы] автобекет-ке бар-ды-м. (NET-ÖK)

beauty-ACC one see-IP LV.C-CV] bus.station-DAT go-PAST.3

'In order to see (just once) the beauty who rules over my freedom and who took my mind (= who I am crazy about), I went to the bus station.'

To sum up this section, in the examples above it was shown that the non-finite Inflection heads $-\dot{G} A n,-y / A t I n,-(A) r,-(I) p,-\dot{G} A l I$ and the Nominalizer $-w$ can embed high light verbs. (Note that due to space considerations no such examples were given with the converb heads -MAy, -MAyInšA, - $\dot{G} A s I n$, which can also embed high light verbs.) As the table in (71) has indicated (for a more detailed table see Table 1 in the Appendix), I assume that non-finite Inflection heads are in the same position as finite Inflection heads (such as $-D I$, $-y / A(d I),-\dot{G} A n,-(I) p(t I)$, etc.). First of all, it is notewothry that some of these finite and nonfinite Inflection heads are homonymous (e.g. $-\dot{G} A n,-y / A t I n,-(A) r)$, although their aspectual content differs. We have to leave for further research to determine what the connection is 
between the homonymous Inflection heads. Moreover, the fact that finite and non-finite Inflection heads can embed the same verbal structure (i.e. $\left.\mathrm{v}_{\mathrm{Con}} \mathrm{P}\right)$ also supports my approach.

\subsubsection{A non-finite head that cannot embed high light verbs: $-y / A$}

In contrast to the above mentioned non-finite heads, $-y / A$ cannot embed high light verbs. These non-finite converb clauses express manner, i.e. how the event of the superordinate predicate is being performed.

The converb head $-y / A$ is relatively rare, ${ }^{37}$ which can be explained by the restrictions concerning its usage. First of all, $-y / A$ can only take a durative atelic verb as its complement, i.e. only to Activity and Stative verbs. That is, the event of the verb to which $-y / A$ attaches cannot have a terminal point (i.e. it must be atelic), and it has to have a duration. ${ }^{38}$ Consider the following two ungrammatical sentences: in (82) ašwlan- 'to become angry' is an Achievement verb, which has a terminal point, but no duration, hence it cannot be combined with adjectives that imply duration, such as 'for an hour' or 'within an hour', however, it may be combined with adjectives such as 'completely'.

*Ерлан [ашулан-а] қайm-mbl. (based on KV, TTBS; PC.)
Erlan [become.angry-CV] return-PAST.3
Intended: 'Erlan came back having become angry.'

In (83) bwïndir- 'to suffocate, strangle' is an Accomplishment verb, i.e. there is a preparatory stage that culminates in the terminal point (when the suffocated person dies). That is, Accomplishment verbs are durative and telic. Since $-y / A$ cannot attach to telic verbs, the following sentence is infelicitous.

\footnotetext{
${ }^{37}$ I am not going to address here not non-finite, "lexicalized" cases, for instance, when the allomorph - $a$ occurs on the verb bol- 'to become' (bola), which assigns dative case to its complement, and expresses purpose (cf. (i)). (QG: 659)

(i) Бұл бала сіз-ге бола кел-іпті. (QG: 659) this child you.FRML-DAT for come-EVID.3

'This child (apparently) came here for you.'

Moreover, I won't discuss the extremely marginal purpose usage of -y/A-clauses with motion verbs. (QG: 659) An illustrative example is given in (ii).

(ii) Жас-may біреу Штейгер-ді шақыр-а кет-ті. (QG 659) young-like someone Šteyger-ACC call-CV leave-PAST.3

'A youngish person went to call Shteiger.'

${ }^{38}$ For further discussion about $-y / A$-clauses see 3.3.1 in the next chapter.
} 
(83) *Ерлан Асқ̧ар-ды [буындыр-а] өлтір-ді. (based on KV, TTBS; PC.)

Erlan Asqar-ACC [strangle-CV] kill-PAST.3

Intended: 'Erlan killed Askar by strangling him.'

Note that in Questionnaire 1 all verbs which $-y / A$ follows are Activity or Stative verbs (cf. in (1) kül- 'to smile', in (5) qumart- 'to yearn', in (8) köyil qoy- 'to pay attention', in (10) qwan'to enjoy', in (13) külimde- 'to smile', in (17) žügir - 'to run', in (21) arbayda- 'to tatter'). ${ }^{39}$

The event in the non-finite $-y / A$-clause must overlap in time with the event in the superordinate clause. This is illustrated in examples (84) and (85), in which the events of the $-y / A$-marked non-finite predicates, expressed by the Stative verb qumart- 'to yearn' and by the Activity verb žügir- 'to run', take place at the same time as the events of the superordinate predicates (qara- 'to look, to watch' and sïq- 'to go out', respectively). ${ }^{40}$

\section{Гүл-дер-ге [ [жұмарт-а] қ̧ара-дыл-м. 8/8}

flower-PL-DAT [yearn-CV] look-PAST-SG1

'I looked at the flowers yearning.'

\section{Дала-ва [жүгір-е] шық-ты. 8/7 (1 QM)}

outside-DAT [run-CV] go.out-PAST.3

'He went out running.'

This type of non-finite head cannot select for any high light verb. This is illustrated with the following ill-formed sentences, in which $-y / A$ embeds the Continuous high light verb. ${ }^{41}$

$$
\begin{aligned}
& \text { *Гүл-дер-ге [құмарт-ып ж⿻үр-e] қара-дыл-м. 8/1 (1 QM) } \\
& \text { flower-PL-DAT [yearn-IP LV.CONT-CV] look-PAST-SG1 }
\end{aligned}
$$

\footnotetext{
${ }^{39}$ The numbers in the parentheses refer to the sentences in Questionnaire 1.

${ }^{40}$ For more examples see sentences (1), (5), (8), (10), (13) and (17) in the questionnaire.

${ }^{41}$ I have tested several more similar sentences with $-y / A$, all of them were ungrammatical in every single case when $-y / A$ followed a high light verb. In sentences (3), (12), (16) in the questionnaire the $-y / A$-head embeds a Completive light verb; in sentences (7), (15), (20), (23) -y/A follows the Continuous light verbs. None of these sentences are grammatical.
} 


\section{(87) *Дала-ва [жүгір-іп жүр-е] шық-ты. 8/0 outside-DAT [run-IP LV.CONT-CV] go.out-PAST.3}

Intended: 'He went out running.'

Since $-y / A$ cannot embed the high light verbs, we can presume that it embeds only a VoiceP. Moreover, I assume that, similarly to manner adverbials, $-y / A$-clauses are adjoined to VoiceP (i.e. they are event-internal adverbs, cf. Ernst 2002: 259-260). (For some additional arguments in favour of $-y / A$ being able to embed only VoiceP-s see section 3.3.1 in the next chapter.) First of all, this is supported by the position of $-y / A$-clauses: in neutral sentences they are immediately preverbal (cf. (84) and (85), and also the sentences in the questionnaire). Moreover, if the predicate is negated, the negation applies to the $-y / A$-clause and the superordinate predicate as one unit. In (88) the complex modified event 'sniffing by surrounding' is negated.

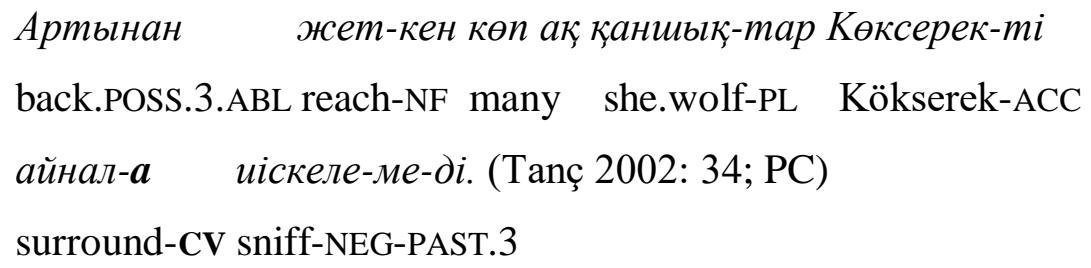

'The many she-wolves that followed him didn't sniffed Kökserek by surrounding him.'

\subsection{Notes on complex converb morphemes}

There are four cases that seem to be an exception from the generalization established above: $-y /$ A tura (tur- 'to stand, stand up'), - $y /$ A sala (sal- 'to put, raise'), - $y /$ A bere (ber- 'to give'), $-y / A$ kele (kel- 'to come, arrive'). In these cases the converb head $-y / A$ follows verbs that, at first sight, seem to be high light verbs.

However, the meaning of these high light verb(-looking) constructions (-y/A tur-, $-y / A$ sal-, -y/A ber-, - $y /$ A kel-) is different from their "regular" meanings (Oralbaeva 1979: 45). $-y / A$ tur- is mostly used with the imperative, and it is quite difficult to attribute one single function 
to it. ${ }^{42}$ In contrast, as a non-finite head $-y /$ A tura expresses 'in spite of (an action or an event)' (Qapasova 2004: 154; Ysqaqov 1967/II: 204).

[Айжан-ның сөз-i ес-ін-де бол-а тұра],

[Ayžan-GEN word-POSS.3 mind-POSS.3-LOC COP-COMPL.CV]

Сандугаш мектеп-ке кел-ме-ді. (Qapasova 2004: 154)

Sandwġaš school-DAT come-NEG-PAST.3

'Despite that Aizhan's words were in her head, Sandugash didn't come to school.'

The construction $-y / A$ ber- can express two different things: firstly, the event is going on without any interruption (in this case it attaches to verbs that are atelic). Secondly, it can express that the action is carried out without paying attention to it (Akbaba 2011: 75-86; Ysqaqov 1974: 266). On the other hand, the complex non-finite head $-y /$ A bere means 'when, as soon as', as shown in (90).

(90) [Микрофон дауыс-ьл шыс-а бере],

[mįcrophone sound-CM come.out-COMPL.CV]

отыр-ван-дар тынынитал-дыл. (Qараsоva 2004: 155)

sit-NF-PL become.calm-PAST.3

'When/ As soon as the sound of microphone was to be heard, those (who were) sitting became quiet.'

The high light verb construction $-y / A$ sal- expresses that the action is performed in a neglectful manner, without paying attention to it (Akbaba 2011: 231-233; Ysqaqov 1974: 267). In contrast, $-y / A$ sala means that right after the event marked with $-y / A$ sala, the event of the superordinate clause takes place (Oralbaeva 1979: 43-44, 54).

\footnotetext{
${ }^{42}$ As Akbaba (2012: 252-253) puts it, the action in these sentences is perceived as being "temporary".
} 
[Аптальққ-та-вы сурет-ті көр-е сала],

[journal-LOC-ADJ picture-ACC see-COMPL.CV]

бір тұлва-ның бейне-сі көз-іміз-ге от-тай бас-ыл-дыл. (M/N-MS)

one person-GEN appearance-POSS.3 eye-POSS.PL1-DAT arrow-like push-PASS-PAST.3

'The moment we saw the picture in the journal, a man's appearance caught our eyes.'

In case of $-y / \mathrm{A} \mathrm{kel-}$, all the examples I was able to find show that this construction is only used in the complex morpheme -y/A kele (cf. Akbaba 2012: 156-158). -y/A kele expresses that the action or event that is followed by the event of the main clause lasts for a longer time.

(92) [Әнъгімелес-е келе], түсініс-ті. (Oralbaeva 1979: 44)

[chat-COMPL.CV] agree-PAST.3

'After chatting (for a longer time), they came to an agreement.'

To sum up, the complex converb heads $-y / A$ tura, $-y / A$ sala, $-y / A$ bere and $-y / A$ kele do not include the high light verb constructions $-y /$ A tur-, $-y / A$ sal- and $-y / A$ ber-. Thus they do not pose a problem for our above described analysis (i.e. that $-y / A$ cannot embed high light verbs). Moreover, I propose that $-y / A$ tura, $-y / A$ sala, $-y / A$ bere and $-y / A$ kele should be dealt with as independent converb heads (hence the glossing "complex converb"). The table in (93) is the revised version of the similar table offered in Chapter 1. 
(93) Converb heads and their meanings (final version)

\begin{tabular}{|l|l|}
\hline Converb suffixes & Meaning (roughly) \\
\hline$-(I) p$ & $\begin{array}{l}\text { 'after', 'when'; '-ing' (manner); 'and'; 'as'; } \\
\text { 'since' etc. }\end{array}$ \\
\hline$-y / A$ & '-ing' (manner) \\
\hline$-M A y$ & $\begin{array}{l}\text { Negative allomorph of -(I)p and -y/A; 'without'; } \\
\text { 'until' }\end{array}$ \\
\hline$-\dot{G} A l I$ & 'since'; 'in order to' \\
\hline$-\dot{G} A \sin$ & 'when'; 'because' \\
\hline$-M A y I n s ̌ A$ & 'unless', 'until', 'as long as' \\
\hline$-y /$ A tura & 'in spite of (an action or an event)' \\
\hline$-y /$ A sala & 'when, as soon as' \\
\hline$-y /$ A bere & 'when, as soon as' \\
\hline$-y /$ A kele & 'after (a long-lasting event)' \\
\hline
\end{tabular}

\subsection{Subjects of non-finite clauses}

It is well-known that some non-finite clauses cannot have an overt independent (i.e. independent from the superordinate clause's) subject. For instance, in Turkish such non-finite clauses are headed by $-m A k,-(y) A \ldots-(y) A$, and $-(y) A r A k$ (Göksel \& Kerslake 2011: 267). Most grammars and linguistic works written about (especially Kipchak, South Siberian or Turki) Turkic non-finite clauses merely mention that it is impossible to indicate an overt subject in certain non-finite clauses. ${ }^{43}$ If our aim was to write a descriptive grammar about Kazakh (or about any Turkic language), this approach would be perfectly acceptable. However, since I attempt here not only to give a description about the Kazakh data, but also to explain them, we have to go further than simply noting whether a clause may have an independent subject or not. That is, I aim to explain why certain clauses can, while others cannot have their own subjects.

This subsection is structured as follows: 2.2.1 is an introductory section, in which it will be presented which non-finite clauses can have an independent subject, and if they can

\footnotetext{
${ }^{43}$ For example, Yüce $\left(1999^{2}: 44-45\right)$ merely mentions that $-(y) A r A k$-headed Turkish converb clauses do not (or just very rarely) have an independent subject. A similar approach is taken by Aydemir (2009: 66), when he analyzes the $-A /-y$-headed converb clauses in Altai Tuvan.
} 
have an independent subject, what case-marking it bears. Section 2.2.2 establishes that clauses in which the non-finite head attaches low cannot have an independent subject, while clauses with high-attaching non-finite heads can.

\subsubsection{Subjects and subject cases in Kazakh - An overview}

We shall begin with finite clauses, which are discussed here to give a reference point for our further discussion. The subjects of the finite clauses are always in the nominative case. In Kazakh the marking of the nominative case is zero $(-\varnothing)$. The subject (Norio) in example (94) is in the nominative case (i.e. there is no overt marking on it). The parentheses indicate that the subject can be dropped if its reference is clear from the discourse.

(Норио) Қазақстан-ва ен ал алваш 1989 жыл-ьл

Norįo Kazakhstan-DAT SUPRL first 1989 year-TEMP

Арал теңіз-ін зертте-у-ге кел-ген. (M/N-AA)

Aral sea-CM.ACC research-NNF-DAT come-PERF ${ }^{44} .3$

'Norio came to Kazakhstan for the very first time in 1989 to conduct research on the Aral sea.'

\subsubsection{Subjects of converb clauses}

The issue of subjects in the non-finite domain is less straightforward. First of all, not all of the non-finite clauses can have an independent (i.e. independent from the superordinate clause's) subject: $-y / A$-headed converb clauses cannot have their own subjects. This is, in fact, not surprising, since they express manner. The table in (95) shows whether and which converb clauses can have an independent subject. The third column informs the reader about the rough meaning of these converb clauses.

\footnotetext{
${ }^{44}$ Finite $-\dot{G} A n$ is glossed as perfect throughout this work. Note, however, that the so-called perfect in Kazakh is different from, for instance, English present perfect. As Straughn (2011: 61-76) convincingly argues, Kazakh (finite) $-\dot{G} A n$ expresses that the event is "indefinite" and not marked for confirmativity. Indefiniteness, in this sense, means that no, or few, details of the circumstances (e.g. exact time) of the event are known to the speaker, i.e. the event marked with $-\dot{G} A n$ came about sometime in the past, but it is not specified when exactly (Straughn 2011: 70-75).
} 
(95) Subjects of converb clauses

\begin{tabular}{|c|c|c|}
\hline $\begin{array}{l}\text { Can the clause have an } \\
\text { independent subject? }\end{array}$ & $\begin{array}{l}\text { The converb morpheme } \\
\text { that heads the adverbial } \\
\text { clause }\end{array}$ & Meaning (roughly) \\
\hline $\begin{array}{l}\text { yes } \\
\text { (some: } \text { no }^{45} \text { ) }\end{array}$ & $-(I) p$ & $\begin{array}{l}\text { 'after', 'when'; '-ing' } \\
\text { (manner); 'and'; 'as'; 'since' } \\
\text { etc. }\end{array}$ \\
\hline no & $-y / A$ & '-ing' (manner) \\
\hline yes & $-M A y$ & $\begin{array}{l}\text { Negative allomorph of }-(I) p \\
\text { and }-y / A \text {; 'without'; 'until' }\end{array}$ \\
\hline yes & $-\dot{G} A l I$ & 'since'; 'in order to' \\
\hline yes & - $\dot{G A s I n}$ & 'when'; 'because' \\
\hline yes & $-M A y \operatorname{Ins} A$ & 'unless', 'until' \\
\hline yes & $-y / A$ tura & $\begin{array}{l}\text { 'in spite of (an action or an } \\
\text { event)' }\end{array}$ \\
\hline yes & $-y / A$ sala & 'when, as soon as' \\
\hline yes & $-y / A$ bere & 'when, as soon as' \\
\hline yes & $-y /$ A kele & 'after (a long-lasting event)' \\
\hline
\end{tabular}

If they have an independent subject, it is in the "unmarked" 46 case. The following three illustrative examples show that the subjects of the converb clauses that allow an independent subject are in the "unmarked" case. In (96) the non-finite clause is headed by -GAlI, in (97) by $-M A y$, and in (98) by - GAsIn. The parentheses indicate that the subjects can be left out if their reference is obvious from the context.

[(Мен) осы кино-ныл көр-гелі] біраз уақыт өт-ті. (РС.)

[I that movie-ACC see-CV] some time pass-PAST.3

'It's been a while, since I saw that movie.'

\footnotetext{
45 This will be further nuanced in Chapter 3, for certain -(I)p-clauses (those that I will call "predicative adjuncts") cannot have an independent subject.

46 The word "unmarked" is meant to be without any theoretical implications, that is, for the time being I leave it open whether this case is nominative or default. (For a detailed discussion see 2.2.2.)
} 
(97) [Дау-ды (қазы) да ажырат-а ал-май] дауласушы-лар

[debate-ACC judge too separate-A LV-CV] quarreller-PL

патша-ның алд-ына құайта кел-іпті. (KV, BP)

padishah-GEN front.POSS.3.DAT again come-EVID.3

'After even the judge could not sort out the debate, (so) the arguing parties came again to the padishah.'

(98) [Терец жыртыл-ван жұмсақ жер бол-васын]

[deep plough-NF soft ground COP-CV]

топьрак̧-қ̧а кір-іn кет-mi-м. (M/N-GSB)

soil-DAT enter-IP LV.C-PAST-SG1

'Because the ground was ploughed up deeply and (it was) soft, I sank into the soil.'

In converb clauses there is no agreement marking on the predicate of the non-finite clause, ${ }^{47}$ thus in out-of-the-blue sentences the subject of the converb clause will be understood to be the same as in the main clause. However, if there is context, the converb clause's pro subject could be coreferent with a nominal phrase other than the superordinate clause's subject. For example, the pro in (99) could be understood to be the judge if prior to this utterance the judge was mentioned.

[Дау-ды p pro шеш-е ал-май] дауласушы-лар

[debate-ACC solve-A LV-NEG.CV] quarreller-PL

патша-ның алд-ына қайта кел-іпті. (KV, ВР; РС.)

padishah-GEN front.POSS.3.DAT again come-EVID.3

'After the judge could not sort out the debate, the arguing parties came back to the padishah.'

Before we proceed to the next section, one more comment is in order: in 2.1.5.2.1 we have suggested that the $-y /$ A tura ,-y/A sala, $-y / A$ bere and $-y /$ A kele constructions should be dealt with as independent converb heads. It has been shown that these constructions do not include a high light verb. Moreover, they also differ from $-y / A$-clauses in being able to have their own subject. For instance, see sentence (89), in which the $-y /$ A tura-headed clause has an

\footnotetext{
${ }^{47}$ Remember that I do not consider $-s A$-headed conditional/temporal clauses non-finite. For further discussion see Chapter 1 .
} 
independent subject, Ayžannïy sözi 'the word(s) of Aizhan'. Similarly, in (90) the independent subject of the $-y /$ A bere-clause is mikrofon 'microphone'.

However tura, sala, bere or kele may be omitted from these constructions (apparently without any change in meaning), and in these cases we are left with a single $-y / A$-headed predicate. $^{48}$ This is illustrated in the following sentence.

(100) [Біз кел-е], самаурын қ̧ой-ылл-дыл. 8/6 (1 QM)

[we come-(COMPL)CV] samovar put-PASS-PAST.3

'The moment we arrived, the samovar was put (on the table).'

However, these are not identical with the $-y / A$-clauses that express manner and cannot have an independent subject. Firstly, the $-y / A$-headed clause has a temporal rather than a manner meaning; secondly, the omitted tura, sala, bere or kele can be inserted back into the sentence, as shown in (101).

(101) [Біз кел-е сала], самаурын қүой-ылл-ды. 8/7

[we come-COMPL.CV] samovar put-PASS-PAST.3

'The moment we arrived, the samovar was put (on the table).'

The point I would like to make clear here is that there might be examples where the $-y / A$ headed clause seemingly has its own subject (such as in (101)), but these cases are in fact secondary, and they have nothing to do with the manner expressing $-y / A$-clauses.

\subsubsection{Subjects of $-w$-clauses}

The clauses that are headed by the nominalizer ${ }^{49}-w$ can have an independent subject. If the nominal agreement morpheme (the "possessive") is indicated on the $-w$ clause, the subject can be either in the genitive or in the "unmarked" case. In example (102) the nominal agreement is marked, and the subject bears the genitive. (Note that the genitive subject case assignment

\footnotetext{
${ }^{48}$ Cf. sentences (25)-(31) in Questionnaire 1.

${ }^{49}$ For the explanation of this term see Chapter 4. -w-clauses can appear in different syntactic positions, such as in argument position, or they can be complements of postpositions or semantic cases (in which case they form an adverbial clause). The different subtypes of $-w$-clauses bear different subject case. Here, I am not discussing $-w$ clauses in detail, for that see Chapter 4.
} 
is only possible if there is agreement (i.e. possessive) marking in the clause.) In (103) the agreement marking is present, but the subject is in the "unmarked" case. In (104) there is no agreement marking on the predicate of the $-w$-clause, thus the overt subject (swiq 'cold') is in the "unmarked" case. ${ }^{50}$ Although none of these three examples are ungrammatical, some agreement and subject case marking patterns are more preferred than others. (For details see Chapter 4.)

[Суық-тың түс-у-і]-мен бірге маусым-дық

[cold-GEN fall-NNF-POSS.3]-INSTR together season-ADJ

ауру-лар да пайда бол-ады. 20/15

illness-PL too (come.into.existence)-PRES.3

'Together with the setting in of the cold (weather), seasonal illnesses appear as well.'

(103) ?[Суық түс-у-і]-мен бірге маусылм-дық

[cold fall-NNF-POSS.3]-INSTR together season-ADJ

ауру-лар да пайда бол-адыл. 20/9 (2 QM; 1 NA)

illness-PL too (come.into.existence)-PRES.3

'Together with the setting in of the cold (weather), seasonal illnesses appear as well.'

(104) \%[Суық түс-у]-мен бірге маусым-дық

[cold fall-NNF]-INSTR together season-ADJ

ауру-лар да пайда бол-адьл. 20/12 (2 QM)

illness-PL too (come.into.existence)-PRES.3

'Together with the setting in of the cold (weather), seasonal illnesses appear as well.'

\subsubsection{Subjects of $-\dot{G} A n,-y / A t I n$ and $-(A) r$-clauses}

There is another type of non-finite clause that can be used in various syntactic positions $;{ }^{51}$ these are headed by the suffixes $-\dot{G} A n,-y / A t I n$ or $-(A) r$. These too can have their own overt subjects, which - similarly to -w-clauses - can either bear the genitive or the "unmarked" case depending on several factors. If the (nominal) agreement is indicated, the

\footnotetext{
${ }^{50}$ Examples which are followed by numbers are taken from Questionnaire 2.

${ }^{51}$ These can head relative clauses, argument clauses and clauses that are complements of postpositions or semantic cases. For details see Chapter 4.
} 
subject is either in genitive, as it is the case in (105), where the subject of the - $\dot{G} A n$-headed clause, bay küyewleri 'his (i.e. Bek's) rich sons-in-law', bears the genitive (indicated in bold). Or the subject can be in the "unmarked" case too. This is illustrated in (106), in which the nominal agreement marking ("possessive") is present, but the subject, men ' $\mathrm{I}$ ', is in the "unmarked" case. The third alternative is not to indicate the nominal agreement marking, in which case the subject can only be in the unmarked case, as shown in (107). ${ }^{52}$

(105) Бек [бай күйеу-лер-і-нің киік-тің ет-ін

Bek [rich son.in.law-PL-POSS.3-GEN antelope-GEN meat-POSS.3.ACC

кім-нен ал-ван-ын] айт-ады. (KV, AS)

who-ABL get-NF-POSS.3]ACC say-PRES.3

'Bek explained from whom his rich sons-in-law got the meat of the antelope.'

(106) [Мен даң̧ъыра соқ̧-қ̧ан-ымм]-да, қ̧ырық

[I kind.of.drum hit-NF-POSS.1]-LOC forty

есік-ті бекіт-іп таста-ц̧дар. 20/15 (1 QM)

door-ACC close-IP LV.C-IMP.PL2

'When I hit the drum, close the forty doors.'

(107) [Мен даңъвыра соқ̧-қ̧ан]-да, қ̧ырық

[I kind.of.drum hit-NF]-LOC forty

есік-ті бекіт-іп таста-ц̧дар. 20/18

door-ACC close-IP LV.C-IMP.PL2

'When I hit the drum, close the forty doors.'

${ }^{52}$ For a more detailed discussion on the $-w$, and $-\dot{G} A n,-y / A t I n,-(A) r$-headed clauses see Chapter 4. 
The table in (108) summarizes the possible subject cases in the non-finite clauses.

(108) Subject case marking patterns in nominalized and Inflectional non-finite clauses

\begin{tabular}{|c|c|c|}
\hline \multicolumn{2}{|l|}{ Non-finite clause types } & Subject's case marking \\
\hline \multicolumn{2}{|c|}{$-y / A$-headed converb clauses (and an -(I)p-clause type) } & - \\
\hline \multicolumn{2}{|c|}{ Converb clauses (that can have their own subject) } & "unmarked case" \\
\hline \multirow[t]{3}{*}{$-w$-clauses } & with agreement marking & genitive \\
\hline & with agreement marking & "unmarked case" \\
\hline & $\begin{array}{l}\text { without agreement } \\
\text { marking }\end{array}$ & "unmarked case" \\
\hline \multirow[t]{3}{*}{$-\dot{G} A n,-y / A t I n,-(A) r$-clauses } & with agreement marking & genitive \\
\hline & with agreement marking & "unmarked case" \\
\hline & agreement & "unmarked case" \\
\hline
\end{tabular}

\subsubsection{Correlation between the position of non-finite heads and independent subjects}

Based on the distribution of non-finite heads with respect to high light verbs, we have presumed that the $-y / A$-head can only embed VoiceP, while all the other non-finite heads are able to embed a bigger structure, $\mathrm{v}_{\mathrm{Cont}} \mathrm{P}$. Thus it was assumed that finite, converb and Inflectional non-finite heads, which are all able to embed high light verbs, are Inflection heads $\left(\mathrm{I}^{\mathrm{O}}\right)$. Moreover, $-w$-heads, which I call nominalizers, can also embed high light verbs. These, i.e. finite, converb (with the exception of $-y / A$ ), Inflectional non-finite and nominalizer clauses, may all have their own independent subject. (See Table 1 in the Appendix for a detailed representation.)

It is a striking coincidence that the only converb head that cannot embed high light verbs is $-y / A$, and the only converb clause type that cannot have an independent subject is also the $-y / A$-clauses. (The next chapter addresses a subtype of $-(I) p$-headed clauses that is similar to $-y / A$-clauses in this way.)

Thus a correlation can be observed between the positions of non-finite heads and the possibility of their respective clauses to have an independent subject. It seems that only those clauses can have an independent subject whose head can embed high light verbs. 
According to the Minimalist Program, cases are licensed by a licenser. For instance, the subject case (which is generally the nominative) in finite clauses is mostly analysed as being licensed by the Tense head. These licensers (for example, $\mathrm{T}^{\mathrm{o}}$-s) have so-called "uninterpretable" features (e.g. the nominative case) that need to be checked by a syntactic object with matching interpretable features (e.g. by a noun phrase). Thus noun phrases that need case move to the positions where cases are licensed in order to get case. So two things come together: a noun phrase that needs case and a licenser that has to license a case (Adger 2003: 166-199).

I propose that Inflection head is the licenser of the nominative subject case in Kazakh. This is supported by the fact that all clauses whose head is an Inflection head can have an independent subject in the "unmarked" case (henceforth: nominative case). Converb clauses (except for $-y / A$ and a subtype of -(I)p-clauses) and Inflectional non-finites (-GAn, $-y / A t I n$ and $-(A) r)$ are such instances. (Note that this analysis only holds for the Inflectional non-finites without agreement marking, whose subject is in the "unmarked" case.) The treerepresentation of this structure is given below.

(109) Nominative subject case assignment in converb and Inflectional non-finite clauses

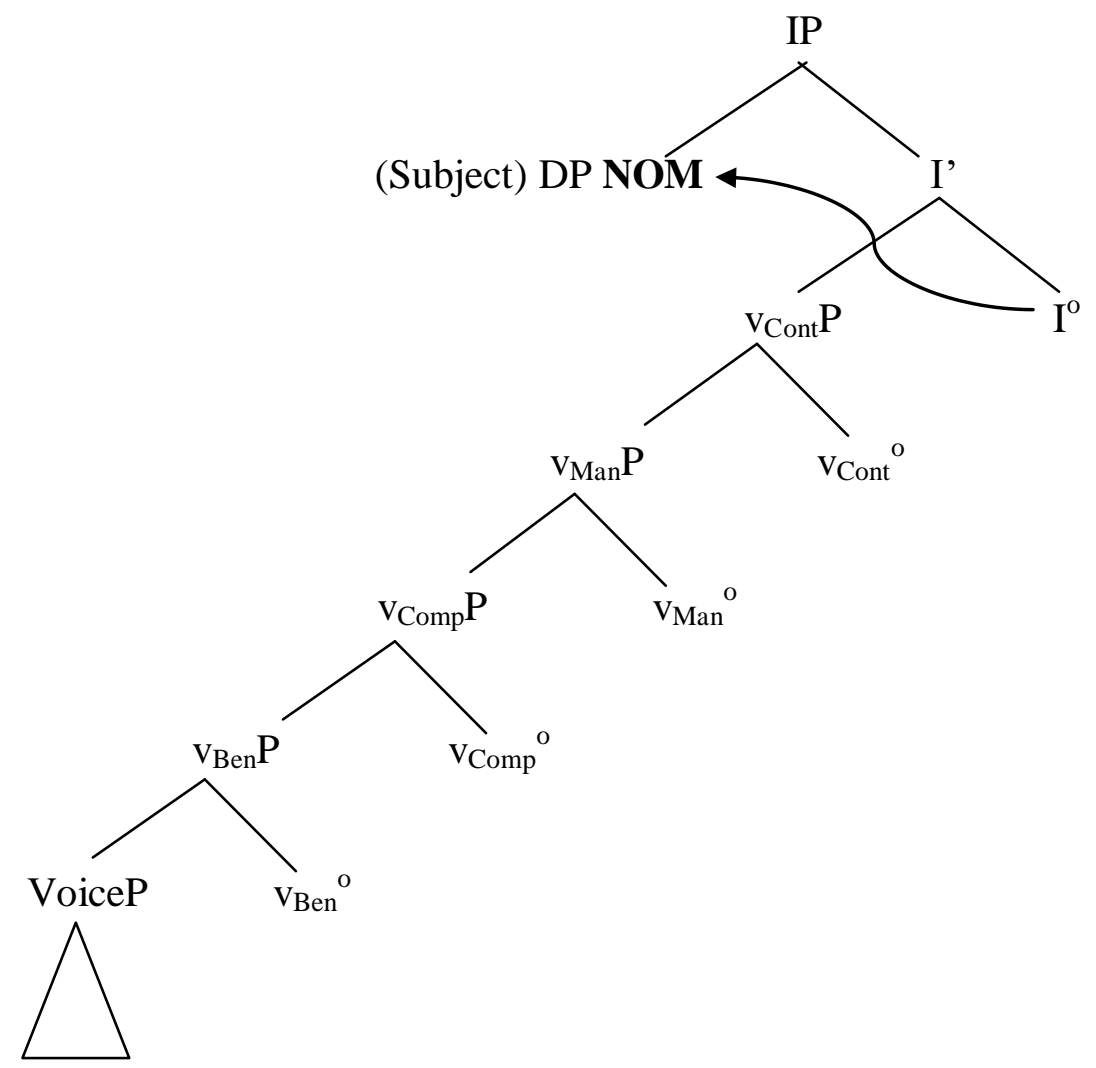


As described above, the converb suffix $-y / A$ cannot embed functional categories higher than VoiceP, hence the $-y / A$-head is not in the same syntactic position as the other Inflection heads. That is, $-y / A$ is "lower" in the structure. I argue that only Inflection heads can license nominative subject case, and other (lower) heads cannot, and for this reason the $-y / A$-head is not capable of licensing subject case. This is the explanation why $-y / A$-clauses cannot have their own subject. The tree in (110) offers a representation of these constructions. $\left(\operatorname{Adj}_{\mathrm{Pred}} \mathrm{P}\right.$ stands for Predicative Adjunct Phrase, for discussion see 3.3.1 in the next chapter.)

(110) No subject case assignment in - $y / A$-clauses

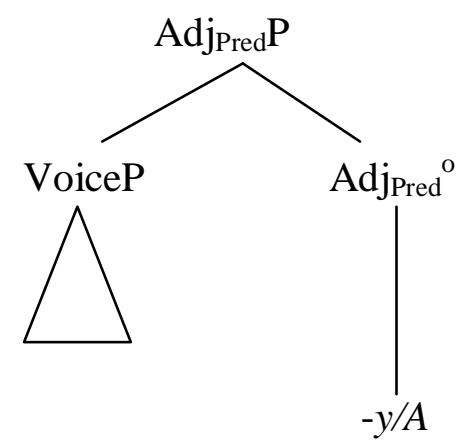

A thorough analysis of genitive subjects will be offered in Chapter 4. Nevertheless, some issues need to be discussed in this chapter too. As it will be shown in the subsequent chapters, only noun heads can assign genitive case in Kazakh. Thus the above-discussed converb and (not nominalized) Inflectional non-finite clauses cannot have a genitive subject, because the head of their clause is not nominal. On the other hand, as claimed above, $-w-$ clauses are nominal, consequently $-w$ must be some sort of nominal head. (For evidence supporting that $-w$-clauses are indeed nominal see Chapter 4 .) Thus the nominal $-w$-head is able to license genitive subject case, hence the subject noun phrase can get case and thus appear in the clause. In cases when the subject is in the "unmarked" case, I assume that it is in the unmarked genitive case. Note that in Turkic languages it is typical that the accusative and genitive cases can be overtly marked or unmarked. Several factors may influence whether the accusative or genitive cases are assigned overtly or not; for instance, non-referential noun phrases cannot bear overt accusative or genitive case, but there are some other factors. Nevertheless, what is important for us here is that the genitive can be overt or phonologically null. Thus the subject of the $-w$-clause can be in the unmarked (i.e. phonologically null) genitive case too. In the following preliminary tree representation of $-w$-clauses, "Nom", 
stands for Nominal head, which represents the $-w$-head. (The final version of this tree can be found in Chapter 4.)

(111) Case assignment in - $w$-headed clauses (first version)

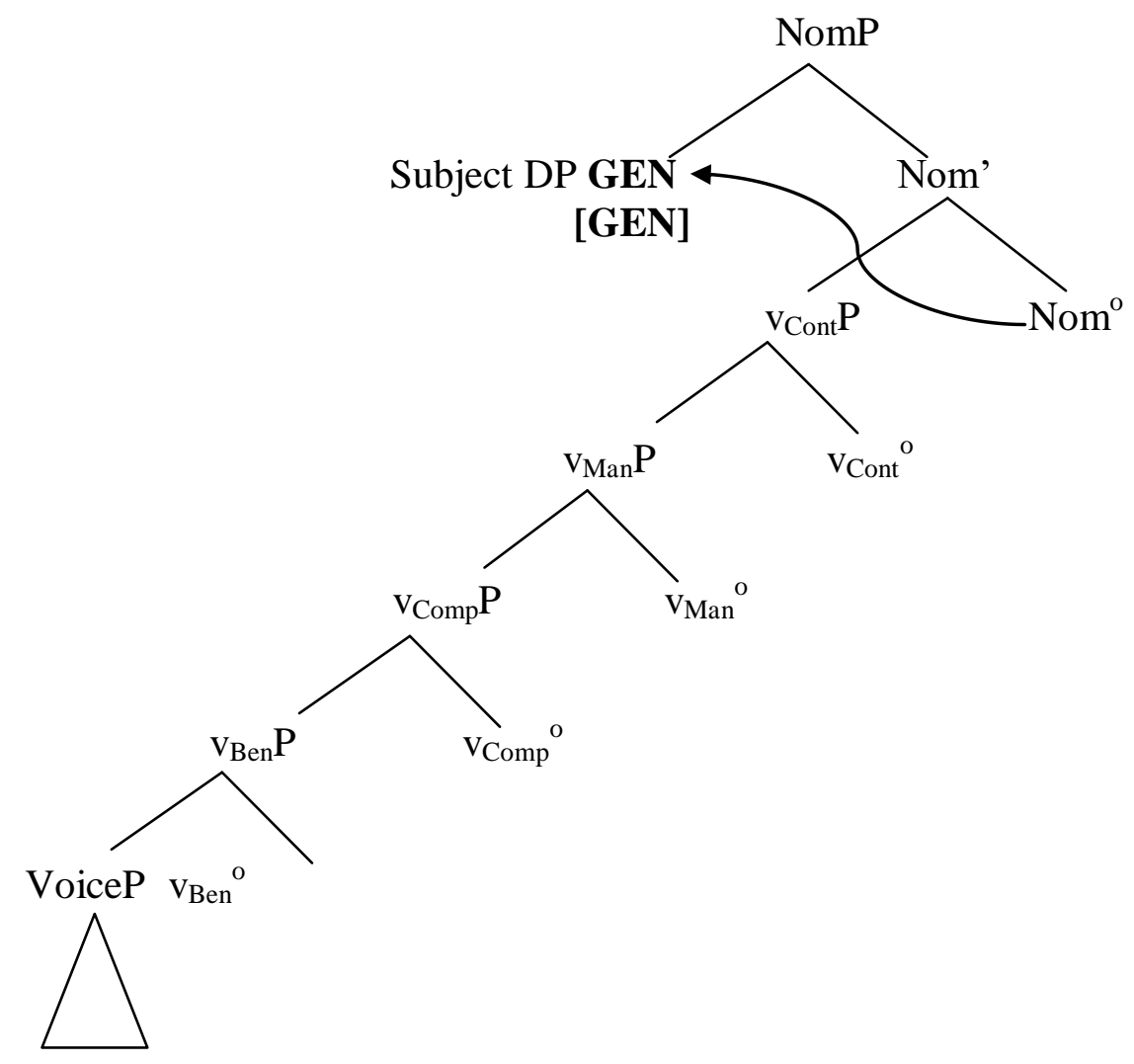

As for the $-\dot{G} A n,-y / A t I n$ and $-(A) r$-headed clauses in which the clausal head is followed by an agreement marker, the subject of these clauses can be either in the "unmarked" or in the genitive case. As it will be argued in Chapter 4, in these cases a nominal head embeds the Inflection heads $-\dot{G} A n,-y / A t I n$ or $-(A) r$, hence these are, like $-w$-clauses, nominalized. Since these clauses are nominalized, their subject can be marked with overt or phonologically null genitive case, the same way it has been demonstrated for $-w$-clauses. The following tree shows this. The abbreviation "Nom" denote a nominal head, whose nature will be discussed in Chapter 4. 
(112) Case assignment in (nominalized) $-\dot{G} A n$, $-y /$ AtIn and $-(A) r$-headed non-finite clauses (first version)

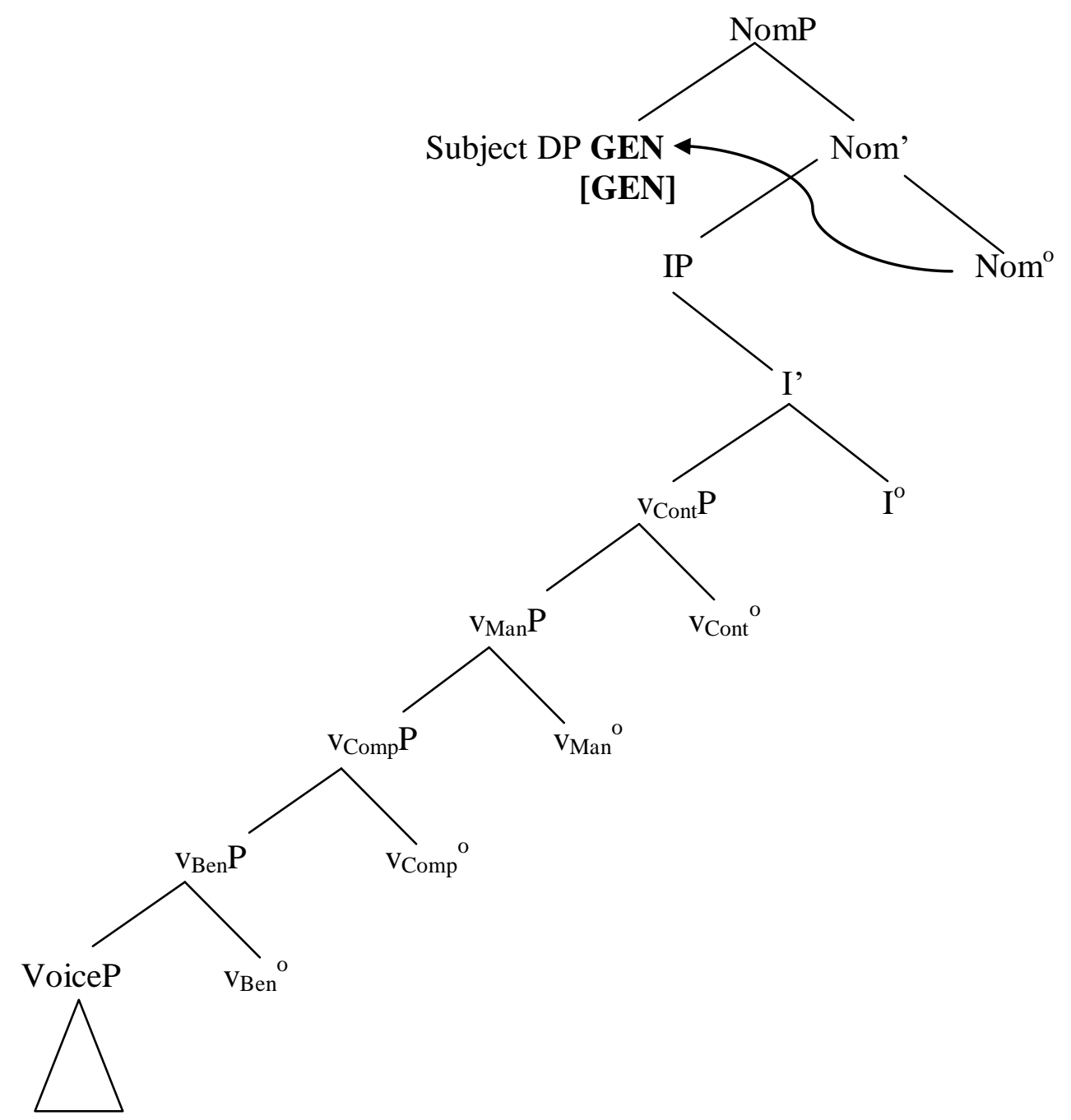




\section{The underspecified vocabulary item $-(I) p$}

\subsection{Introduction}

This chapter deals with the syntax of the non-finite clauses headed by the suffix -(I)p. I intend to explain how $-(I) p$-clauses are different from other (adverbial) non-finite clauses, and to address all the important characteristics of these clauses in a unified analysis.

Two important features of the -(I)p-headed non-finites are mentioned in the literature, which, I think, characterize only these non-finite clauses. The first is the abundance of meanings. -(I)p-clauses can express: manner (QG: 658, 684), purpose (with motion verbs) (QG: 659), cause (QG: 685), a linking relation (when the -(I)p-marked element seems to be independent of the main clause) (QG: 704-705), and temporal relation (perfect or imperfect) (QG: 705). The second is the scope-over phenomenon, that is, the scope of the matrix clause's functional categories may extend over the -(I)p-clause as well (e.g. Johanson (1995: 338-339) and Yüce $\left(1999^{2}:\right.$ 53-54) emphasize the scope-over phenomenon in the case of negation), which is quite odd if we assume that $-(I) p$-clauses are subordinated.

In this chapter, I attempt to explain all these phenomena arguing that suffix $-(I) p$ is an underspecified vocabulary item, which can head different types of clauses, including subordinated and coordinated ones.

\subsection{Preliminaries}

In this chapter, only the $-(I) p$-headed ${ }^{53}$ non-finite clauses are going to be discussed. However, there are many other cases when an -(I)p-marked item is used not as a non-finite clause. In the following, I will mention some of these usages.

Some of these have already been mentioned: the usages when $-(I) p$ is used in verb formation (cf. 2.1.3.5) and when $-(I) p$ is used as a dissociated morpheme in light verb

\footnotetext{
${ }^{53}$ If the morpheme follows a verb that ends in a vowel, the - $p$ allomorph will be used (oqi-p 'read-IP'), if it follows a verb that ends in a consonant, the allomorphs used can either be -ip (kör-ip 'see-IP') or -ip (bol-ïp 'become-IP') depending on the quality of the verb's last vowel (palatal or velar). It is noteworthy that if the verb ends in /p/, the /p/ will change to /w/: žap- 'to cover, close, finish' > žawïp 'cover-IP'. If the verb ends in /k/ or /q/, the last consonant becomes voiced: $a \boldsymbol{q}$ - 'to flow' > å̈̈̈p- 'flow-IP'.
} 
constructions (cf. 2.1.4.2). Another not non-finite usage is when an -(I)p-marked verb is reanalyzed as an adverbial. Such an example is söytip 'thus, so, like this' (< söyt- 'to do like this'), which is a sentence adverbial that can usually be found in sentence initial position.

(1) Сөйmin, жігіт жарль бол-ады. (NET-BA2)

thus young.man poor become-PRES.3

'Thus the young man became poor.'

The -(I)p-marked verb can also be reanalyzed as a postposition, as in case of -ABL bastap 'from [time] on' (< basta- 'to begin, start').

(2) Астана-Щучье тас жол-ьл [ертең-нен бастап]

Astana Ščučce stone road-CM [tomorrow-ABL from]

ақыль бол-ады. (NET-TV7)

with.charge become-PRES.3

'The Astana-Shuchie road is going to be a toll-road from tomorrow on.'

Another example for reanalysis is $\operatorname{dep}$ ( $<d e$ - 'to say'), which has several usages. The most frequent ones are its usages as a discourse particle (see (3)) and when it follows an optative verb and expresses purpose (see (4)). Naturally, the description about the uses of dep could be further nuanced, but this is not the goal of our present study.

(3) Хан бала-ны әкел-іп: «Ocbl-ныл өлтір!»- деп

khan child-ACC bring-CV this-ACC kill.IMP.SG2 DISC.PART

бір уәзір-іне бер-еді. (KV, HMV)

one vizier-POSS.3.DAT give-PRES.3

'The khan brought the child, and gave it to one of his viziers and said: "Kill this".'

(4) «Мен өл-ген-де, дйел-іме зорльқ құыл-ма-сын»деп

I die-NF-LOC woman-POSS.SG3.DAT unfairness do-NEG-OPT.3 in.order.to

көпес хан-мен тамыр бол-ьлптыл. (KV, KQMМ)

merchant khan-INSTR vein become-EVID. 3

'The merchant befriended the khan, so that if he dies, his wife wouldn't see any harm.' 
Moreover, there is a formative $-L A p$ in Kazakh, which is built from the verbalizing suffix $-L A$ and the converb morpheme $-(I) p$. (However, the verb forms in $-L A$ are generally not used independently, as the following examples show.) Some examples with the formative -LAp are offered here: azdap 'a little (of something)' (*azda-; az 'little, a few'), bir-birlep 'on by one' (*bir-birle-, *birle-; bir 'one'), ekewlep 'in twos, two by two' (*ekewle-; eki, ekew 'two'), mïydap 'thousands (of something)' (*mïyda-; mïy 'thousand'), sagattap 'for hours' (*sagatta-; sag்at 'hour'), žĭldap 'for years' (*žilda-; žil 'year'). (For more examples see: Ysqaqov 1967: 182-183, Tanç 2002: 80, QG: 549.)

Since the above mentioned usages are not non-finite clauses, they are not going to be discussed any further.

\section{$3.3-(I) p$ in low and high positions}

In this section I am going to argue that $-(I) p$ can turn up in more than one syntactic position, and the different syntactic configurations in which it appears is responsible for the wide range of meanings these clauses can express.

\subsubsection{Predicative adjuncts}

In the previous chapter, in 2.1.5.2, it was mentioned that the converb suffix $-y / A$ attaches only to atelic and durative verbs. The results of my questionnaire indicate that in these clauses, the suffix $-y / A$ can always be replaced by $-(I) p$. This is shown in the following examples: in (5) the morpheme $-y / A$ heads the non-finite clause indicated in brackets, in (6) $-y / A$ is replaced by -(I) $p$ without any change in meaning. For similar examples see sentences (1)-(2); (5)-(6); (8)(9); (10)-(11); (13)-(14); (17)-(18), (21)-(22) in Questionnaire 1.

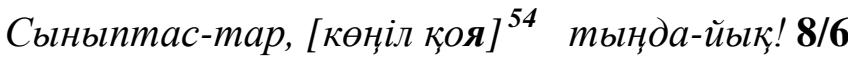

$$
\begin{aligned}
& \text { classmate-PL [heart put.CV] listen-OPT.PL1 } \\
& \text { 'Classmates, let's listen carefully.' }
\end{aligned}
$$

\footnotetext{
${ }^{54}$ Könil qoy- is an idiom, which means 'to pay careful attention'. In this example the verb qoy-is followed by the allomorph $-a$, and $/ \mathrm{ya} /$ is rendered in Kazakh orthography as $\langle я\rangle$.
} 
classmate-PL [heart put-CV] listen-OPT.PL1

'Classmates, let's listen carefully.'

In fact, if we take a look at the above mentioned sentences in Questionnaire 1, we can see that more native speakers marked the variants with the suffix $-(I) p$ as grammatical than the $-y / A$ variants, although both sentence variants seem to be acceptable. ${ }^{55} \mathrm{I}$ assume that both morphemes are grammatical in this syntactic construction, and the difference between them is only stylistic.

However, in contrast to $-y / A,-(I) p$ can be attached to verbs of any lexical aspect type, i.e. it may follow Activity, Accomplishment, Achievement, Semelfactive or Stative verbs. Recall the two ungrammatical sentences given in 2.1.5.2, in which $-y / A$ could not be attached to the Achievement verb ašwlan- 'to become angry' and to the Accomplishment verb bwïndir- 'to suffocate, strangle'. These sentences can be fixed if $-y / A$ is replaced by $-(I) p$, as shown in (7) and (8).

Ерлан [ашулан-ыл] қайт-mbl. (based on KV TTBS; PC.)

Erlan [become.angry-CV] come.back-PAST.3

'Erlan came back having become angry.'

(8) Ерлан Асқұр-ды [буындыр-ылn] өлтір-ді. (based on KV, TTBS; PC.)

Erlan Asqar-ACC [strangle-CV] kill-PAST.3

'Erlan killed Askar by strangling him.'

This means that in contrast to $-y / A,-(I) p$ does not have the same restrictions in terms of what kind of verb it attaches to.

Notice that these $-(I) p$-clauses, similarly to $-y / A$-clauses, do not have temporal meaning, they express manner instead (cf. (5)-(6)). I call this type of -(I)p-clauses "predicative adjuncts", and I claim that this meaning arises from the merging position of

\footnotetext{
${ }^{55} \mathrm{I}$ have asked several native speakers to explain the difference between $-y / A$ and $-(I) p$ in these sentences. They told me that they do not feel that there is any difference between these sentences in meaning; some of them added, however, that $-(I) p$ seemed to be more appropriate, or 'less colloquial'.
} 
$-(I) p$ in the verb phrase, and from the structural position the $-(I) p$-clause occupies in the superordinate clause.

\subsubsection{The -(I)p-head (in predicative adjuncts) embeds VoiceP}

I would like to argue that in "predicative adjunct" constructions -(I)p embeds VoiceP, and not a smaller or a bigger structure. That in these cases $-(I) p$ does not embed a smaller structure than VoiceP is supported by the fact that these $-(I) p$-headed non-finite clauses are always active in terms of diathesis.

To make this point clear, let me take a look at the similar Hungarian constructions headed by the converb head $-v A$. $-v A$-headed non-finite clauses in Hungarian have a lot in common with the Kazakh -(I)p-headed non-finites. Most importantly, Hungarian $-v A$ may have various merging locations (Tóth 2000, Bartos 2009), which makes it very similar to the Kazakh constructions in question. For instance, it can be adjoined to Voice Phrases, similarly to the above discussed Kazakh -(I)p. Consider the following Hungarian examples, which are the Hungarian equivalents of the Kazakh examples (6), (7) and (8).

Osztálytárs-ak, [oda-figyel-ve] hallgassuk (az elöadás-t).

classemate-PL [PART-pay.attention-CV] listen.OPT.PL1 the lecture-ACC

'Classmates, let's listen (to the lecture) carefully.'

Erlan [fel-dühöd-ve] tér-t vissza.

Erlan [PART-become.angry-CV] return-PAST.SG.3 PART

'Erlan came back having become angry.'

(11) Erlan Aszkar-t [fojtogat-va] öl-te meg.

Erlan Askar-ACC [strangle-CV] kill-PAST.DEF.SG3 PART

'Erlan killed Askar by strangling him.'

However, another type of Hungarian $-v A$ clause has "passive meaning" without any passive morphology. (Hungarian, for the most part, lacks morphological passive anyway.) These are called "modifying adjuncts with passive diathesis" by Tóth (2000). In example (12), $-v A$ follows the verb (meg)kötöz 'to bind, tie up', which is transitive, and János is clearly its 
internal argument (cf. the finite sentence in (13), where János is the object). But in (12) János is understood to be the subject of the $-v A$-clause, which is explained in the literature by the location of the $-v A$-head. $-v A$ attaches to (some kind of) $v \mathrm{P}$, that is, before Voice ${ }^{\mathrm{o}}$ could merge into the structure. In the absence of the Voice projection, there is no external argument in the non-finite clause that could be interpreted as the subject; moreover, the accusative case cannot be assigned to the internal argument (which is János in this case). Because the - $v A$-head is not in the Tense position, it cannot assign nominative case to its subject, hence the internal argument must be covert, represented by PRO (Tóth 2000: 247-252). Since this phenomenon never occurs in Kazakh, it is safe to claim that $-(I) p$ does not select for a structure smaller than VoiceP.

János $_{i}\left[P R O_{i}\right.$ kötelek-kel meg-kötöz-ve] ül-t a szobá-ban. (Tóth 2000: 240) János [ropes-INSTR PART-bind-CV] sit-PAST.SG3 the room-LOC 'János was sitting in the room being tied up with ropes.'

A katona kötelek-kel meg-kötöz-te János-t. the soldier ropes-INSTR PART-bind-PAST.DEF.SG.3 János-ACC 'The soldier tied up János with ropes.'

For proving that in "predicative adjunct" constructions -(I)p does not attach to a higher phrase than VoiceP, we can use the same diagnostics we did in the case of $-y / A$-clauses in Chapter 2. It turns out that in "predicative adjunct" constructions -(I)p cannot follow the "high" light verbs - as the results of Questionnaire 1 indicate it. In sentence (14) ${ }^{56}$ the suffix -(I) $p$ marks a predicative adjunct clause. ${ }^{57}$ Notice that in predicative adjunct constructions (I) $p$ cannot select for high light verbs (such as the Completive in (15)). Example (16) is the modified version of (7); but in contrast to the above-given example, (16) is not grammatical, because the $-(I) p$ embeds a high light verb construction. Thus we can conclude that in predicative adjuncts the non-finite head $-(I) p$ is situated lower in the structure than the high light verbs.

\footnotetext{
${ }^{56}$ This and the next example correspond to (2) and (4) in Questionnaire 1.

${ }^{57}$ For more examples see sentences (22) and (24) in Questionnaire 1.
} 
(14)

Ол менің құшад-ыма [күл-іп] кір-ді. 8/6 (1 QM)

(s)he I.GEN lap-POSS.SG1.DAT [smile-CV] go.in-PAST.3

'(S)he sat on my lap smiling.'

(15)

* Ол менің құшад-blма [күл-іп кет-іn] кір-ді. 8/0

(s)he I.GEN lap-POSS.SG1.DAT [smile-IP LV.C-CV] go.in-PAST.3

Intended: '(S)he sat on my lap smiling.'

(16) *Ерлан [ашулан-ыл кет-іn] қ̧айт-mы. (based on TTBS; PC.)

Erlan [become.angry-IP LV.C-CV] come.back-PAST.3

Intended: 'Erlan came back having become angry.'

Thus the claim that in predicative adjunct constructions -(I)p embeds VoiceP seems to be well-founded. Since in these constructions VoiceP is present, there is an external argument in the clause, and accusative case can be assigned. However, since the position where -(I)p (or $-y / A$ ) is located is not a subject-case assigning position (see Chapter 2 for further discussion), the subject can never be overt in the non-finite clause.

\subsubsection{Predicative adjunct -(I)p-clauses adjoined to the matrix VoiceP}

Predicative adjunct clauses modify the matrix Voice Phrase, which is supported by the nonfinites' position in the matrix clause. These -(I)p-clauses are immediately preverbal in neutral sentences, ${ }^{58}$ only (contrastive) focus can intervene between the $-(I) p$ clause and the matrix predicate. This can be observed in examples (6)-(8) and (14) above.

\footnotetext{
${ }^{58}$ In some very marked contexts (mostly in poetic texts) the predicative adjunct clause can be post-verbal too, as shown in (i).

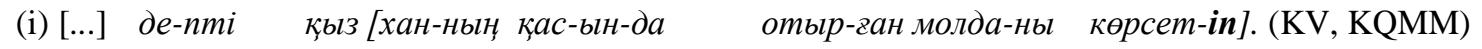
say-EVID.3 girl [khan-GEN side-POSS.3-LOC sit-NF mullah-ACC show-CV]

'[...] said the girl pointing at the mullah who was sitting next to the khan.'
} 


\subsubsection{Summary}

The following tree represents the syntactic structure of predicative adjunct $-(I) p$-clauses. As can be seen, -(I)p attaches to Voice Phrase forming a $\operatorname{Adj}_{\text {pred }} \mathrm{P}$ (Predicative Adjunct Phrase), which merges into the matrix clause at Voice' level. (The FP stands for "Functional Phrase", i.e. any kind of functional projection that may select for a VoiceP.)

(17) Predicative adjunct $-y / A$ and $-(I) p$-clauses

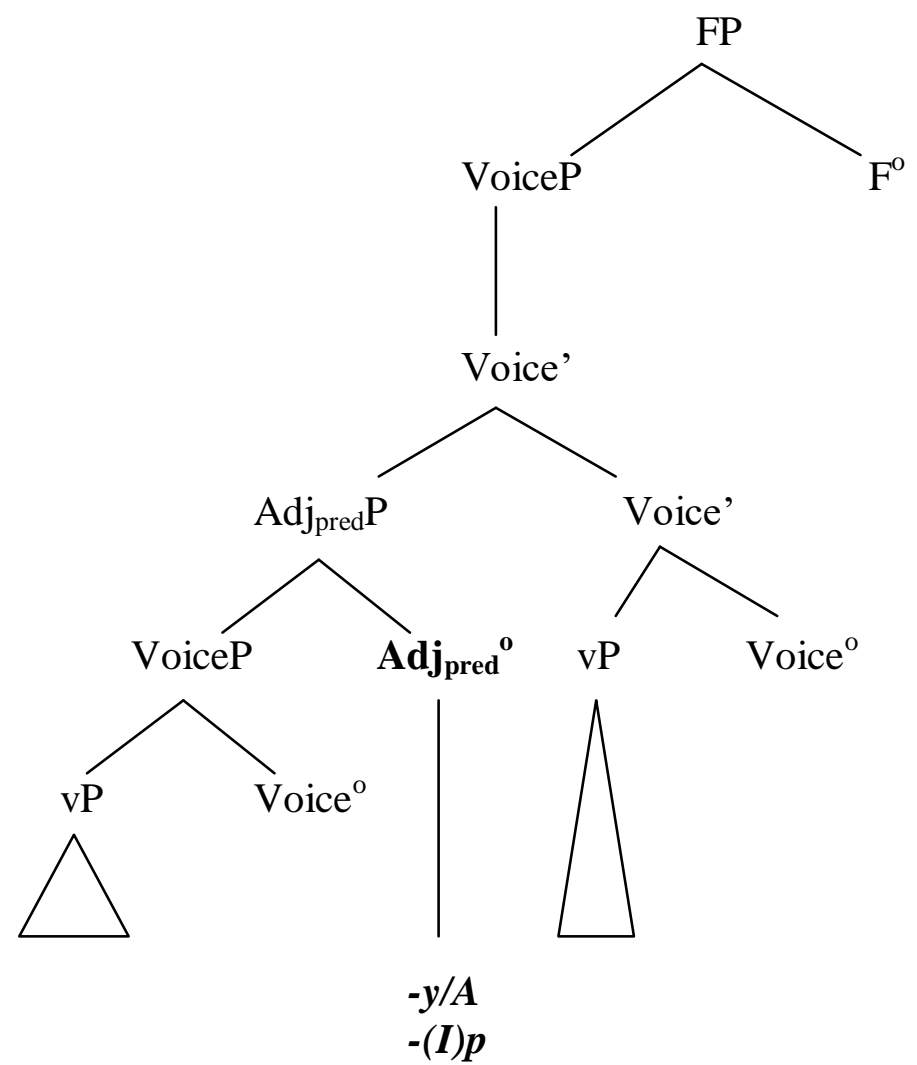




\subsubsection{High attaching $-(I) p$-constructions}

There is another type of $-(I) p$-clause that does not express manner, but (some rather vague) temporal or causal relationship to the matrix clause. The following example illustrates this $-(I) p$ clause-type.

(18) [Қатын-ьым өл-іn], әйел ізде-n шыв-ылn еді-м. (KV, TTBS)

[wife-POSS.SG1 die-CV] woman search-CV leave-PERF COP.PAST-SG1

'When/After/Because my wife had died, I set out to look for a [new] woman.'

I claim that these -(I)p-clauses are syntactically different from the above-discussed predicative adjuncts, and the difference in meaning between them originates from their different syntactic structure.

\subsubsection{1 -(I)p embeds high light verbs}

In this type of $-(I) p$-clause, the position of the non-finite head $-(I) p$ is different than in predicative adjuncts. In these constructions, $-(I) p$ may embed the high light verbs, in contrast to predicative adjuncts, which indicates that the $-(I) p$-head is situated higher than in the predicative adjunct constructions. The examples below illustrate that $-(I) p$ can embed high light verbs, such as the Completive (in (19)), Manner (in (20)) and Continuous (in (21)) high light verb phrases.

(19) Шал [куан-ып кет-іn], бала-ның үлкен-діг-ін-дей old.man [rejoice-IP LV.C-CV] child-GEN big-NOM-POSS.3-like

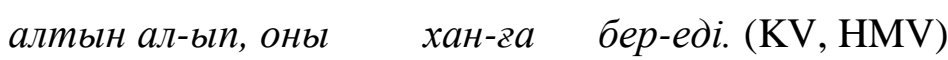
gold get-CV (s)he.ACC khan-DAT give-PRES.3

'The old man became delighted [with the offer], got as much gold as the child's weight, and gave him to the khan.' 
Қорқыт [Сырдария су-ына бір кілем-ді төсе-й сал-ыn], соның

Qorqiit [Sïrdarịa water-CM.DAT one carpet-ACC spread-A LV.M-CV] that.GEN

Үст-ін-де құобыз-ын тарт-ып отыр-а бер-еді. (M/N-QÄ6: 35)

top-POSS.3-LOC kobyz-POSS.3.ACC play-IP LV.CONT-A LV-PRES.3

'Korkyt laid out a carpet on the water of Syr Darya, and on it, he started to play his kobyz.'

(21) Мұхтар патша бір күн-i [ұйқта-п жжат-ып], түс көр-іпті. (KV, ВР) Muxtar padishah one day-TEMP [sleep-IP LV.CONT-CV] dream see-EVID.3

'One day when/while Muhtar padishah was sleeping, he had a dream.'

The fact that in these constructions -(I)p can embed the high light verbs indicates that it in the Inflection slot. (Cf. the discussion in Chapter 2.) This also means that these type of -(I)pclauses may have their own, independent subject.

\subsubsection{2 -(I)p modifies the matrix Inflection Phrase}

In contrast to predicative adjunct $-(I) p$-clauses, these $-(I) p$-clauses in neutral sentences are not obligatorily immediately preverbal, which suggests that they modify a higher category than the predicative adjuncts (i.e. higher than VoiceP). I propose that this category is the matrix Inflection Phrase. (This is why I labelled them "high attaching"-(I)p-constructions.) Consider the following example, in which the (high attaching) -(I)p-clause and the matrix predicate are separated from each other by the instrumental-marked argument of qoštas- , the subject of the matrix clause (Rawšan) and by a temporal non-finite clause.

(22) [Үлкен-дер шәй іш-іп], Қызылл-дың шекер қ̧ау-ынынын же-n [big-PL tea dring-CV] Qïzïl-GEN sugar bag-POSS.3.ABL eat-IP

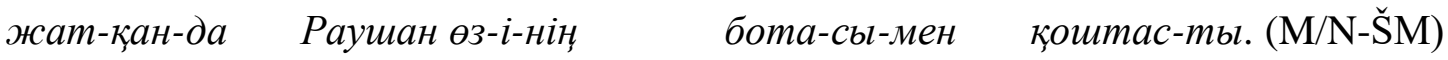
LV.CONT-NF-LOC Rawšan self-POSS.3-GEN colt-POSS.3-INSTR say.goodbye-PAST.3 'When the grown-ups drank tea, Raushan, while eating from Kyzyl's sugar bag, said goodbye to her own (camel) colt. / The grown-ups drank tea, and Raushan, while eating from Kyzyl's sugar bag, said goodbye to her own (camel) colt.' 


\subsubsection{Summary}

The following tree illustrates the structure of sentences in which a high attaching $-(I) p$ construction modifies an Inflection Phrase. The non-finite Inflection head -(I)p may come after $\mathrm{v}_{\mathrm{Cont}} \mathrm{P}$, or any lower verb phrase.

(23) High attaching $-(I) p$-constructions

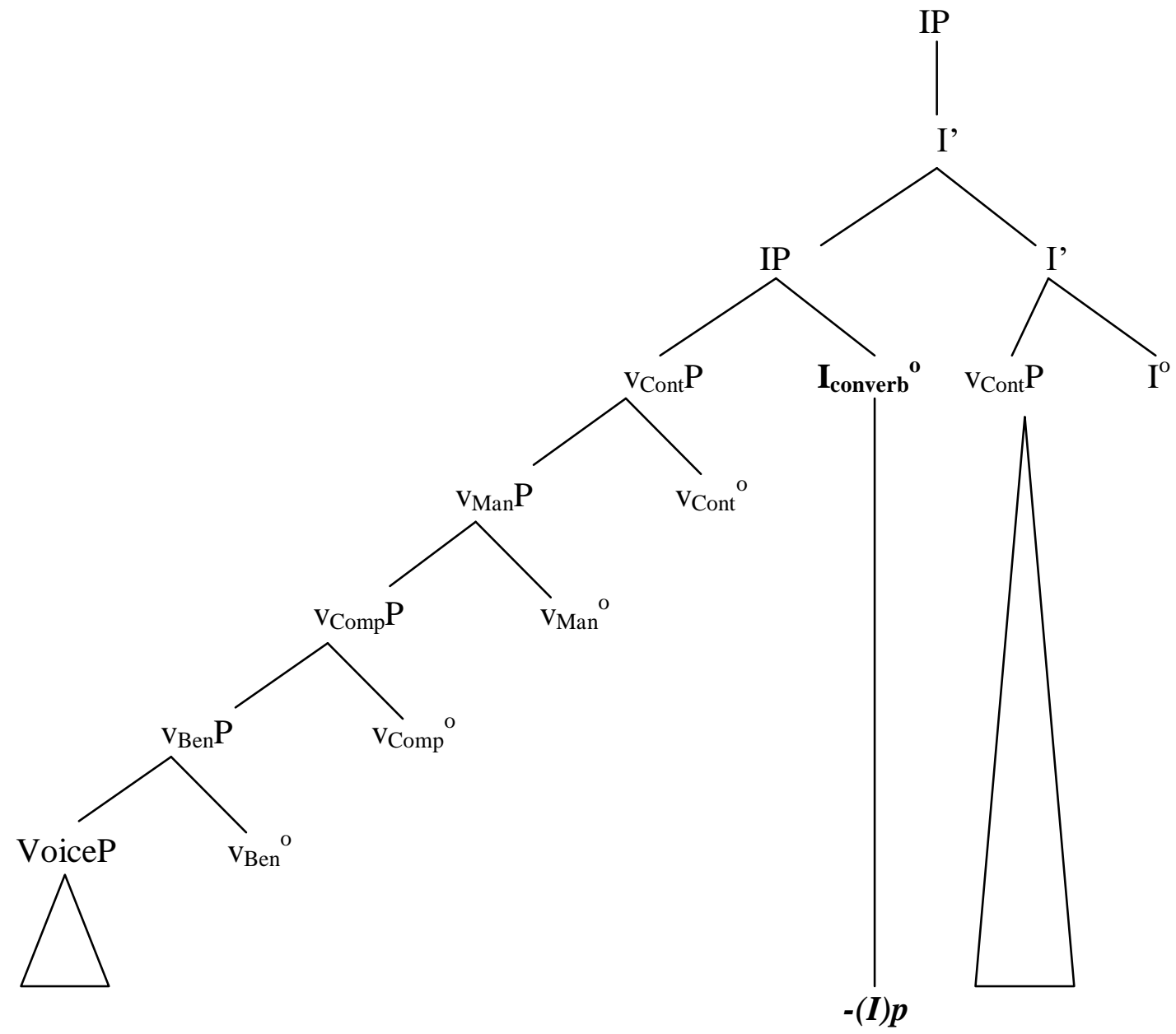

\subsubsection{Underspecification}

In 3.3.1 and 3.3.2 it was demonstrated that the non-finite -(I)p-head can attach low (to the VoiceP) or high (to the $\mathrm{v}_{\mathrm{Cont}} \mathrm{P}$ ) in the derivation, and the various meanings, such as manner, temporal (including 'while', 'when', 'after') and causal meanings, come about as the consequence of the different positions the $-(I) p$-head takes. (The manner interpretation arises when $-(I) p$ embeds the VoiceP, the other meanings when $-(I) p$ follows the $\mathrm{v}_{\text {Cont }} \mathrm{P}$.) 
How can we account for -(I)p's syntactic behaviour? A possible approach would be to posit that there are two homonymous $-(I) p$ morphemes $\left(-(I) p^{l}\right.$ and $\left.-(I) p^{2}\right)$, and say that $-(I) p^{1}$ selects for VoiceP, while $-(I) p^{2}$ selects for $\mathrm{v}_{\mathrm{Cont}} \mathrm{P}$, moreover that they have different semantics (the former would denote manner, the latter temporal and/or causal relations). Although this is a viable way to account for the syntactic and semantic phenomena presented above, I think, an analysis that does not assume two separate morphemes would be more preferable.

I propose that there is only one vocabulary item $-(I) p$, which is underspecified in several respects: first of all, it is not specified with respect to the position in which it must be inserted. As it was shown in Chapter 2, there are two structural positions where non-finite heads can be inserted: right above VoiceP or $\mathrm{v}_{\text {Cont }} \mathrm{P}$. All the other vocabulary items (such as $-y / A,-\dot{G} A l I,-\dot{G} A n,-y / A t I n,-w$ etc.) are specified for the position in which they can be inserted in; i.e. $-y / A$ can only occur in the low position embedding VoiceP; the other vocabulary items only appear in the higher Inflection slot following $\mathrm{v}_{\mathrm{Cont}} \mathrm{P}$. $-(I) p$ is clearly different from these: it can adjoin both VoiceP and $\mathrm{v}_{\text {Cont }} \mathrm{P}$, which indicates that it is not specified with respect to the position it is inserted in. (For a final formulation of this view see 3.5.)

It is also noteworthy that $-(I) p$ does not bear any special semantic specification (except probably "non-prospective" ${ }^{\text {59) }}$ regarding the aspectual relationship between the sub- and superordinated clause. (In contrast to many "complex" converb suffixes that consist of, for instance, the non-finite head $-(A) r$ and a postposition or a semantic case, which always refers to prospective events (compared to the time of the matrix clause's event).) This observation follows from the fact that non-finite $-(I) p$-clauses can be interpreted as perfect and imperfect as well (but never prospective).

In the above given (19)-(20), the -(I)p-clause is interpreted as perfect. However, when the Continuous high light verb is present (but in other cases, too, when the verbs' lexical aspectual properties allow it, cf. (25)), the event in the -(I)p-clause will be interpreted as happening at the same time as the event of the superordinate predicate. Consider the following example (and also (21)), in which the -(I)p-head follows the Continuous high light verb construction -(I)p tur-, and the -(I)p-clause is interpreted as imperfective, i.e. the events in the non-finite and the matrix clause take place at the same time. In (25) there is no Continuous marker present in the $-(I) p$-clause, still $-(I) p$ is imperfective there.

\footnotetext{
${ }^{59}$ I cannot aim here to give a detailed analysis about the Kazakh aspectual system, so labelling -(I)p-clauses "non-prospective" is only an observation. If in future research it gets established that, for example, there are no "negative features" (such as "non-prospective") in the Kazakh aspectual system, then my claims have to be modified in accordance with that system.
} 


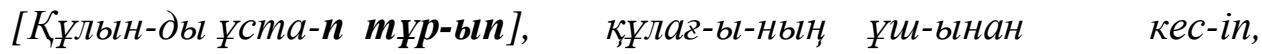
[foal-ACC hold-IP LV.CONT-CV] ear-POSS.3-GEN end-POSS.3.ABL cut-CV

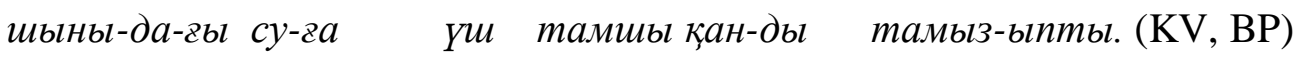
glass-LOC-ADJ water-DAT three drop blood-ACC drip-EVID. 3 'Holding the foal, he cut the end of its ear, and dripped three drops of blood into the water in the glass.'

(25) [Сейіл-де жүр-іп], бір кез-де жеміс егіс-іне кел-еді. (KV, TÜU) [walk-LOC walk-CV] one time-LOC fruit field-CM.DAT arrive-PRES.3 'While (s)he was taking a nice walk, suddenly (s)he arrived in an orchard.'

These examples suggest that $-(I) p$ does not determine the aspectual relationship between the subordinated and the matrix clause (or at least it does not determine whether this relationship is perfect or imperfect). I assume that the temporal interpretation originates from the semantic and syntactic features of the verb phrases involved, and the context. The abovementioned examples (18)-(20) do not allow for an imperfective interpretation; for example, in case of (18), the event of 'dying' is telic, and not durative, hence the imperfect interpretation of the -(I)p-clause is ruled out; it will be understood as preceding the main clause in time, i.e. it is perfective. However, in (21) and (24) the syntactic structure, i.e. the presence of the Continuous high light verb, indicates that the $-(I) p$-clause should be interpreted as imperfective. Hence I propose to consider $-(I) p$ as an underspecified vocabulary item in terms of aspect, too.

It is noteworthy that Kazakh is not the only language that has an underspecified morpheme that may realize different syntactic nodes: the Hungarian "converb" suffix $-v A$, which we have touched upon in 3.3.1, is such a morpheme. (For a detailed discussion see Tóth 2000 and Bartos 2009.) It has already been mentioned above that it could be inserted below and above VoiceP, moreover, it can also occupy a higher position (defined by Bartos (2009: 96-99) as the IP-space). Depending on $-v A$ 's syntactic position, the interpretation (and the syntactic structure) of the non-finite clause can be radically different: similarly to Kazakh, if $-v A$ is inserted low in the structure (above VoiceP), the non-finite clause will be understood as forming a "secondary predicate" together with the matrix predicate. If $-v A$ is situated in the 
IP-space (i.e. in a higher position), the clause will get a temporal interpretation. These facts are very similar to the Kazakh data.

In what follows, a further type of -(I)p-clause will be discussed. I intend to extend the underspecification-analysis to this type of $-(I) p$-clause.

\subsection{Subordinated and coordinated -(I)p-clauses}

Another very curious thing about $-(I) p$-headed non-finites is that some of them behave like subordinated clauses, while others seem to be coordinated. (As it will become clear shortly, the scope-over phenomenon, mentioned in the introductory section 3.1, is related to this issue.) This is quite odd, especially in comparison with the other non-finite clauses, which are all subordinated.

There are a number of ways to tell subordinated and coordinated clauses apart; in the following we are going to list some criteria relevant for Kazakh.

\subsubsection{The scope-over phenomenon}

In the Introduction (3.1) it was mentioned that one of the conspicuous characteristics of -(I)pclauses is that the scope of the matrix functional categories may extend over them. These cases will be elaborated on in Section 3.4.1.2. But before this, I will be show that the scopeover phenomenon does not come about in all -(I)p-clauses (see 3.4.1.1).

\subsubsection{No scope-over}

In subordinated constructions it is out of the question that the matrix functional categories scope over the subordinated clause. In the following sentence the interpretation 'Deulet didn't see me after not leaving the house.' is not possible. That is, the scope of negation cannot extend over the subordinated non-finite clause.

(26) Дәулет [үй-ден шыққ-қ̧ан]-нан кейін мені көр-ме-ді. (PC.)

Däwlet [house-ABL leave-NF]-ABL after I.ACC see-NEG-PAST.3 


\section{'Deulet didn't see me after leaving the house.'}

In example (27), a subordinated argument clause can be found in square brackets, and yet again, the negation in the main clause cannot scope over the subordinated clause, i.e. the meaning of the sentence cannot be 'The gardener wasn't satisfied that (s)he didn't come.'

(27) Жемісші [кел-ген-ін]е разы бол-ма-ды. (based on KV, TÜU; PC.)

gardener [come-NF-POSS.3]DAT satisfied LV-NEG-PAST.3

'The gardener wasn't satisfied that he/she came.'

Some -(I)p-clauses behave like these subordinated clauses, that is, the matrix functional categories do not scope over them. Consider (28) and (29), where the scope of negation (in the superordinate clause) does not extend over the -(I)p-clause. So (28) cannot have the meaning 'The padishah didn't ask everywhere, (so) he couldn't find anything suspicious.'. Similarly, the interpretation of the $-(I) p$-clause has to be affirmative in (29).

Патиа [әрі-бері сұра-n-сұра-n],

padishah [back.and.forth ask-CV-ask-CV]

ешқ̧андай сезік таб-а ал-ма-nmы. (KV, BP)

nothing doubt find-A LV-NEG-EVID.3

'The padishah asked everywhere, but he couldn't find anything suspicious.'

(29) Өмірбек [Айша-ва өкпеле-п], [...]

Ömirbek [Ayša-DAT become.angry-CV]

ован жасау бер-ме-йді. (KV, AS; PC.)

(s)he.DAT dowry give-NEG-PRES.3

'Ömirbek became angry with Aisha, (so) he didn’t give her dowry.'

\subsubsection{Scope-over in coordinated clauses}

In contrast to subordinated phases/clauses, coordinated phrases/clauses could belong under the scope of one mutual (matrix) functional category (Haspelmath 2007: 15-16). In (30) the coordinated elements are both under the scope of the postposition for. 
In the following example, two verb phrases (shoot and kill) are coordinated, and the scope of negation (and past tense) extends over both of them.

(31) A white officer didn't [shoot and kill] an innocent black boy.

Certain -(I)p-clauses can be situated under the scope of matrix functional categories. Consider (32)-(37), in which the matrix functional categories scope over their respective -(I)pclause. This is very striking in examples such as (32) and (33), where the scope of negation extends over the $-(I) p$-clause. Although the negative suffix is not indicated in any of the -(I)pclauses (i.e. in töbeles-ip and in bolža-p), they will be interpreted as negative (cf. the translation of these sentences). The same holds for the non-finite head $-y /$ AtIn in (32) and the pluperfect marker $-\dot{G} A n$ edi in (33): they are not present in the -(I)p-clause, but they are interpreted as if they were.

Eң̧ жақ̧сы ķacuem-i-

SUPL good quality-POSS.3

[[ешкім-мен [төбелес-іп], сөз-ге кел]-ме-йтін-і еді]. 20/17 (Q2)

[[nobody-INSTR [fight-CV] word-DAT come]-NEG-NF-POSS.3] COP.PAST.3

'His/Her best quality was that (s)he wasn't such who would fight or argue with anyone.'

(33) Айналасындавы елді мекендерді ауыз сумен құамтамасыз етіп отырван Бивако көлінде мұндай феномен пайда болады

деп [ешкім [[болжа-п] бак]-па-ван еді]. (M/N-AA)

DISC.PART [no one [[guess-CV] forsee]-NEG-PERF COP.PAST.3]

'No one had guessed or foreseen that this phenomenon would happen at Bivako lake, which was providing the settlements in the region with drinking water.' 
In sentence (34), the scope of the progressive past extends over the -(I)p-clause (žasïr-ïp), thus it is interpreted as progressive past, too, in spite of the lack of any overt inflection morpheme on it.

[Ботакөз үш кез-дей қуызыл мата-ны

[Botaköz three roll ${ }^{60}$-like red textile-ACC

[[жасыр-ыı] сақ̆та]-n жжүр-yші

[[hide-CV] preserve]-IP LV.CONT-PROG COP.PAST.3]

'Botakoz was hiding and preserving about three rolls of red textile.'

In (35) and (36), the superordinate clauses are non-finite, headed by $-w$ and $-\dot{G} A n$, respectively. Naturally, in the $-(I) p$-clauses no non-finite suffix other than $-(I) p$ is present, still the $-(I) p$-clause in (35) is interpreted as an accusative-marked complement clause, and in (36) as a relative clause.

БІбырай ұстаздық-ты, _ [[мектеп-тер аш-ыn],

Ïbïray profession.of.teachers-ACC [[school-PL open-CV]

қ̧азақ бала-лар-ын оқ̧ыт-у]-ды арманда-йдыл. (M/N-ÏA)

Kazakh child-PL-CM.ACC teach-NNF]-ACC dream-PRES.3

'Ybyrai dreamt of a carrier in education, opening schools and teaching Kazakh children.'

(36) [Қиырдавы Жапоня-да [[mу-ып]- өс]-кен] вальм Норио Исида

[far-away Japan-LOC [[be.born-CV] grow.up]-NF] scientist Norįo İsida осы Арал қ̧асірет-і-мен айналыс-қ̧аль 25 жыл-дан ас-ылтты. (M/N-AA)

this Aral tragedy-CM-INSTR be.engaged-CV 25 year-ABL go.beyond-EVID.3

'More than 25 years passed since the scientist, Norio Isida, who was born and raised in the far-away Japan, has been working on the Aral's tragedy.'

In the following example, the scope of the prospective $-M A q$-head extends to the $-(I) p$-clause as well, i.e. both the event in the $-(I) p$-clause ('to return') and in the main clause ('to kill') is

\footnotetext{
${ }^{60}$ The word $k e z$ denotes a measure unit equal to $71,12 \mathrm{~cm}$.
} 
understood to be planned prospective events, although there is no marking on the -(I)p-clause that would indicate this.

Товыз тоңқылылақ [үй-лер-іне қ̧айт-ыn],

Togïz Tonqilldaq [house-PL-POSS.3.DAT return-CV]

Шіңєкілдек-ті өлтір-мек бол-ады. (shortened from: KV, TTBS)

Šinkildek-ACC kill-PROSP become-PRES.3

'Togyz Tonkyldak wanted to return to their homes and to kill Shinkildek.' (lit.

Togyz Tonkyldak were going to return to their homes, and kill Shinkildek.)

The scope-over phenomenon indicates that at least some $-(I) p$-clauses are in coordinative relationship with the main clause. Analyzing the -(I)p-clauses in sentences (32)(37) as coordinated clauses seems to be in line with the meaning of these clauses: they are not interpreted as temporal (e.g. 'after', 'while'), causal or manner denoting clauses. Rather they indicate a "linking relationship" that can be best translated with the conjunction 'and' into English.

It is noteworthy that the lack of scope-over could, but does not necessarily have to mean that the $-(I) p$-clause is subordinated to the main clause. The scope-over is not obligatory, i.e. it is possible that the scope of a functional category does not extend over both of the coordinates. Consider the following example, in which the -(I)p-clause is coordinated with the clause with the finite subjunctive marking. This claim is supported by the meaning of the $-(I) p$-clause ('and'), and by the fact the scope of the third person subjunctive marking $(-s I n)$ extends over the -(I)p-clause. However, the scope of negation in the second clause does not include the $-(I) p$-clause, that is, the $-(I) p$-clause is not interpreted as negated.

Хан [...] ,,[[үш күн-дік азық-тар-ыlн күндіз пісір-іn],

khan [[three day-ADJ food-PL-POSS.3.ACC daytime cook-CV]

түн-де шам-дар-ын да жақ-па-сын]"

night-LOC candle-PL-POSS.3.ACC PART light-NEG-OPT.3]

деn, амір тарат-ады. (KV, ZEZET)

DISC.PART order spread-PRES.3

'The khan announced his order according to which everyone has to cook their three days' food in the daytime, and no one should lit candles in the night.' 
We can conclude that scope-over only comes about in coordinated clauses, and the sentences where there is no scope-over might or might not be subordinated. Thus, we need additional evidence to prove that (certain) -(I)p-clauses are indeed subordinated.

\subsubsection{Symmetrical and asymmetrical operations}

\subsubsection{Asymmetrical application of certain syntactic operations}

An important criterion that distinguishes coordinated and subordinated constructions is that in sentences that contain one (or more) subordinate clauses, asymmetrical operations are grammatical. Such operations are question formation (wh-movement), focus, relativization etc. On the other hand, asymmetric operations are prohibited in sentences with coordinated clauses (Haspelmath 2007: 5-6). This is referred to as Coordinate Structure Constraint. ${ }^{61}$

In what follows, I am going to use the "question-diagnostics" to show the differences between coordinated and subordinated constructions. (39) contains a subordinated clause, while (41) contains two coordinated clauses. Notice that formulating a question in one of the clauses is grammatical in (40), but ungrammatical in (42). According to the Coordinate Structure Constraint, (42) is infelicitous, because the wh-word (who) was moved asymmetrically to its sentence initial position. That is, the wh-movement came about only in one of the coordinated clauses (i.e. asymmetrically), hence the ungrammaticality of the sentence. In contrast, such asymmetrical operations are allowed in sentences containing a subordinated clause.

(39) You talked to someone [before Joan arrived]. (Haspelmath 2007: 5)

(40) Who did you talk to $\emptyset_{\mathrm{i}}$ [before Joan arrived]? (Haspelmath 2007: 5)

(41) You talked to someone and then Joan arrived. (Haspelmath 2007: 6)

(42) *Who $o_{i}$ did you talk to $\emptyset_{\mathrm{i}}$ and then Joan arrived? (Haspelmath 2007: 6)

\footnotetext{
61 According to the original formulation of Coordinate Structure Constraint "in a coordinate structure, no conjunct may be moved, nor may any element contained in a conjunct be moved out of that conjunct" (Ross 1967: 98-99, non vidi, cited in Postal 1998: 50-55).
} 
The "asymmetrical question" diagnostics can be applied to Kazakh sentences containing subordinated non-finite clauses too. These behave as expected, that is, they allow asymmetrical operations. Each example in (43) through (45) includes a subordinate clause: in (43) the subordinate clause is a (temporal) adverbial clause, in (44) and (45) a subordinated argument clause (of the "reported speech"-type) can be found. Note that the asymmetrical question operation could be in the subordinated clause as well (as shown by (45)).

(43) Дәулет [үй-ден шыққ-қ̧ан]-нан кейін кім-ді көр-ді? (РС.)

Däwlet [house-ABL leave-NF]-ABL after who-ACC see-PAST.3

'Who did Deulet see after leaving the house?'

(44) Жемісші [әйел-і-нің кел-ген-ін]е

gardener [wife-POSS.3-GEN come-NF-POSS.3]DAT

неге разы бол-ма-дыl? (based on KV, TÜU; PC.)

why satisfied LV-NEG-PAST.3

'Why wasn't the gardener satisfied that his wife came?'

(45) Жемісші [кім-нің, кел-ген-ін]е

gardener [who-GEN come-NF-POSS.3]DAT

разы бол-ма-ды? (based on KV, TÜU; PC.)

satisfied LV-NEG-PAST.3

'With whose arrival wasn't the gardener satisfied?'

As expected, asymmetrical operations, consequently asymmetrical questions are infelicitous in Kazakh coordinated clauses. In (46) two finite clauses are coordinated, and as (47) shows it, it leads to ungrammaticality to form question only in one of the coordinates.

(46) [Молда иек қ̧ақ̧-тыл] да, [Айша дала-ва шыz-ьın кет-ті]. (РС.)

[mullah sign hit-PAST.3] PART Ayša outside-DAT go.out-IP leave-PAST.3

'The mullah gave a sign, and Aisha went out.' 
(47) *[Молда иек қ̧ақ̧-тыл] да, [кім дала-ва шыz-bın кет-ті]? (РС.)

[mullah sign hit-PAST.3] PART who outside-DAT go.out-IP leave-PAST.3

'The mullah gave a sign, and who went out?'

Thus, asymmetrical operations offer us a way to distinguish coordinated and subordinated clauses. And as will be shown in 3.4.2.1.1 and 3.4.2.1.2, this diagnostic can be used to establish that there are coordinated and subordinated -(I)p-clauses as well.

\subsection{Asymmetrical operations are grammatical with certain -(I)p-clauses}

In certain sentences containing an -(I)p-clause, asymmetrical questions are grammatical. In the felicitous examples (48)-(50) only the superordinate clauses contain a question, the subordinate $-(I) p$-headed clauses do not.

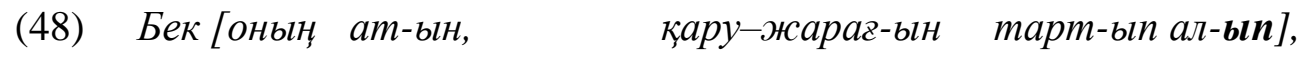

Bek [he.GEN horse-POSS.3.ACC weapon-POSS.3.ACC pull-IP LV.B-CV]

қайда кет-еді? (based on KV, AS; PC.)

where go-PRES. 3

'Where did Bek ${ }_{\mathrm{i}}$ go, after he took away his $\mathrm{j}_{\mathrm{j} *{ }_{\mathrm{i}}}$ horse and weapons?'

(49) Адам [он-он бір жас-та-вь екі қ̧ара бала-ны ерт-іn],

man [ten eleven year-LOC-ADJ two black child-ACC drag.along-CV]

кім-нің алд-ьна кел-іпті? (based on KV, BP; PC.)

who-GEN front-POSS.3.DAT come-EVID.3

'In front of whom did the man go taking two ten, eleven-year-old children with himself?'

(50) Қыз [еркек-ше киін-іn] кім-ге бар-дыл? (based on KV, KQMM; PC.)

girl [man-like dress-CV] who-DAT go-PAST.3

'Who did the girl go to dressed as a man?' 
It is noteworthy that in these examples the -(I)p-clauses have either a temporal (as in (48) and (49)) or a manner reading (as in (50)). What is important is that $-(I) p$-clauses in such sentences are never interpreted as denoting simple linking relationship.

\subsection{Asymmetrical operations are not grammatical with certain -(I)p-clauses}

However, there are sentences that contain -(I)p-clauses in which the asymmetrical operations are infelicitous. Notice that in these sentences the context and/or the grammatical structure enforces a linking interpretation (i.e. 'and' interpretation) between the finite and the $-(I) p$ clause.

(51) *Кеме мейрамхана-да [Асқ̧ар төбелес-іn],

yesterday restaurant-LOC [Asqar fight-CV]

Болат кім-мен сөз-ге кел-ген? (РС.)

Bolat who-INSTR word-DAT come-PERF.3

'Yesterday at the restaurant Askar had a fight, and who did Bolat argue with?'

(52) *Ботакөз [жасыр-ып] не-ні сақта-n жүр-уші еді? (РС.)

Botaköz [hide-CV] what-ACC preserve-IP LV.CONT-PROG COP.PAST.3]

Intended: 'What was Botaköz hiding and preserving?'

(53) *[Құшақ̆ma-n] кім-дi $\quad$ сүй-дi? (based on KV, HMV; PC.)

[hug-CV] who-ACC pet-PAST.3]

Intended: 'Who did (s)he pet and hug'

\subsubsection{Symmetrical syntactic operations}

In sentences containing coordinated clauses certain syntactic operations (such as question formation, focus etc.) have to apply symmetrically in every coordinated clause. In contrast, symmetrical operations of this sort are infelicitous in subordinated clauses (Huddleston \& Pullum 2006: 200-204). Consider the following coordinated clause in (54): the question operation either has to come about in both coordinates symmetrically (shown in (55)), or the 
scope of the question has to extend over both coordinates clauses ${ }^{62}$ (as in (56)). In this latter case, the extraction of the wh-word happens symmetrically in both coordinates. Symmetrical operations of this sort are also known as Across-The-Board (ATB) operations. (Many have applied this diagnostics to show the difference between coordinated and subordinated clauses, e.g. Huddleston \& Pullum 2006, Toosarvandani (2015) etc.)

(54) [My mother bought apples], and [my sister made stewed fruit].

(55) [Who bought apples], and [who made stewed fruit]?

(56) Who [[bought apples] and [made stewed fruit]]?

Compare the above sentences with the following ones, which include a (temporal) subordinated clause indicated with square brackets. As can be seen, symmetrical questions are infelicitous in these examples. So we can conclude that symmetrical operations, which apply to both the super- and the subordinate clause, lead to ungrammaticality.

My sister made stewed fruit [after my mother bought apples].

(58) *Who made stewed fruit [after who bought apples]?

(59) *Who made stewed fruit [after bought apples]?

Turning to the Kazakh data, coordinated clauses are grammatical with symmetrical questions in each coordinate, as illustrated by the following examples. Note that the two clauses are coordinated by $-(I) p$.

[Кім иек қ̧ад-bın], [кім дала-zа шыз-ыın кет-ті]? (РС.)

[who sign hit-CV] [who outside-DAT go.out-IP leave-PAST.3]

'Who did give a sign, and who went out?'

Moreover, symmetrical questions are prohibited in the sentences that include a subordinated clause, such as in (61) and (62). Recall that in these sentences the asymmetrical questions are grammatical (cf. above in 3.4.2.1)

\footnotetext{
${ }^{62}$ Note that this example cannot be interpreted such a way that the $w h$-word only scopes over the first coordinate, because in that case the operation would be asymmetrical, consequently ungrammatical. This is the reason why in the coordinative examples we have shown in the previous section the wh-word was in the second clause, i.e. to rule out the scope-over to both coordinates.
} 
(61) *Дәулет [қай жжер-ден шыққ-қ̧ан]-нан кейін кім-ді көр-ді. (РС.)

Däwlet [which place-ABL leave-NF]-ABL after who-ACC see-PAST.3

$\sim$ 'Who did Deulet see after leaving from where?'

(62) *Жемісші [кім-нің кел-ген-ін]е

gardener [who-GEN come-NF-POSS.3]DAT

неге разы бол-ма-дыл. (based on KV, TÜU; PC.)

why satisfied LV-NEG-PAST.3

'Why wasn't the gardener satisfied that who came?'

\subsection{Symmetrical questions are grammatical in certain -(I)p-clauses}

In the previous sections (3.4.1.2 and 3.4.2.1.2), it was shown that some -(I)p-clauses behave as coordinated clauses with respect to the scope-over phenomenon and with respect to asymmetrical operations. If we try to apply the "symmetrical question"-test to these examples (after some minor changes), we will see that symmetrical questions are grammatical in them. Consider (63) and the above (60), in which asymmetrical questions were infelicitous (cf. above): in (60) and (63), there is a question operation in both the $-(I) p$ and the matrix clause, resulting in a grammatical structure. This is yet another piece of evidence that certain $-(I) p$ clauses are coordinated.

(63) Кеше мейрамхана-да [Асқ̧ар кім-мен төбелес-іп], yesterday restaurant-LOC [Asqar who-INSTR fight-CV]

[Болат кім-мен сөз-ге кел-ген]? (РС.)

[Bolat who-INSTR word-DAT come-PERF.3]

'Yesterday at the restaurant who did Askar have a fight with, and who did Bolat argue with?'

Note that forming questions in each coordinate is not always possible: as I will argue below, -(I) $p$ can conjoin verb phrases (VoiceP-s) and bigger structures as well. In case of VoiceP-coordination, forming separate questions in each clause is not grammatical (such examples are (64) and (65)). Nevertheless, the scope of a wh-word can extend over both of 
these VoiceP-s. (Remember that the scope of one "common" wh-word cannot extend separately over a subordinate and superordinate clause (cf. 3.4.2.2). Hence, we can be sure that the examples below do in fact contain coordination.)

(64) [Ботакөз не-ні [[жасыр-ып] сақта]-n жүр-уші еді.] (РС.)

[Botaköz what-ACC [[hide-CV] preserve]-IP LV.CONT-PROG COP.PAST.3]

'What was Botaköz hiding and preserving?'

(65) [Kiмm-di [[құшақ̧ma-n сүŭ]-di]? (based on KV, HMV; PC.)

[who-ACC [[hug-CV] pet]-PAST.3]

'Who did (s)he pet and hug'

\subsection{Symmetrical questions are ungrammatical in certain $-(I) p$-clauses}

Symmetrical operations are not grammatical in every sentence that contains an $-(I) p$-clause. Recall sentence (28), in which the scope-over of the matrix functional categories did not take place. In that sentence symmetrical questions are ungrammatical, as shown by (66).

(66) *Патша [қайда сұра-n-сұра-n], не man-mbl? (based on KV, BP; PC.) padishah [where ask-CV ask-CV] what find-PAST.3

'What did the padishah find after where did he ask questions?'

\subsubsection{Cataphoras in subordinated and coordinated clauses}

A further criterion that helps us to distinguish between subordinate and coordinated clauses is the reference of cataphoras (i.e. "backwards anaphora"). It has been observed that if two (or more) clauses are coordinated, the pronominal subject in the first clause cannot be co-indexed with the subject of the second (or last) clause. In contrast, the pronominal subjects of subordinate clauses preceding their superordinate clause could be coreferential with the superordinate clause's subject. (This diagnostics has been used in numerous papers to identify coordination and subordination, such as in Haspelmath 2007: 47; Kenesei 1992: 540-551 (see also the similar anaphoric epithet diagnostics in Kenesei 1994: 279-281).) 
Examples (67) and (68) illustrate the above-described generalization: there are two coordinated clauses in (67), and as the indices show, the $3^{\text {rd }}$ person singular pronoun subject (she) of the first clause cannot be coreferential with the second clause's subject (Aisha). But in (68), where the (temporal) subordinated clause precedes the main clause, the pronominal subject in the subordinated clause could be co-indexed with the superordinate clause's subject. This shows that subordinate clauses are embedded into their matrix clauses.

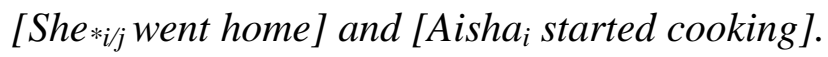

(68) [After she ijj $_{\text {went home], Aisha }}$ started cooking.

The same property holds for Kazakh as well. In the coordinated clauses in (69) and (70) the first clause's pronominal subject ( $o l$ '(s)he, it') cannot be co-referential with the subject of the second clause (Aisha). Moreover, if the pronominal subject of the first clause is dropped (pro-drop is a characteristic feature of Kazakh), the sentence will be rendered ungrammatical (cf. (70)). In short, the second clause's subject can never be co-indexed with the first clause's pronominal subject in Kazakh coordinated sentences.

[Ол*іјj үй-іне кет-ті], ал Айша тамақпісір-у-ге кіріс-ті. (PС.)

[(s)he house-POSS.3.DAT go-PAST.3] and Ayša food cook-NNF-DAT start-PAST.3

'(S)he $*_{\mathrm{i} / \mathrm{j}}$ went home and Aisha $\mathrm{i}_{\mathrm{i}}$ started cooking.'

(70)
*[pro Yü-iH-e
кет-ті], ал [Айша тамақ пісір-у-ге
kipic-mi]. (PC. $\left.{ }^{63}\right)$
[house-POSS.3.DAT go-PAST.3] and [Ayša food cook-NNF-DAT start-PAST.3]
Intended: '(S)he went home and Aisha started cooking.'

As for subordinated clauses, the Kazakh data are again basically the same as the English one described above, with a small twist. Each sentence in (71) through (74) includes a subordinate clause, all of them coming before their respective superordinate clause. In (71) and (73) the subject is a dropped pronoun (pro), while in (72) and (74) an overt pronoun (ol '(s)he, it'). In contrast to coordinated clauses (such as (70)), the preposed subordinated clauses can have a dropped pronoun subject, which can be coreferential with the

\footnotetext{
${ }^{63}$ I asked for grammaticality judgements from several native speakers concerning this and the previous sentence. Their judgements were unanimous.
} 
superordinate clause's subject. This is the pattern that is expected of subordination (cf. the English example above).

The "twist" lies in the overt pronominal subjects: notice that in (72) and (74) the pronoun cannot be co-indexed with the superordinate clause's subject. This is somewhat unexpected in the light of the English example in (68): why can the overt pronominal subject in the subordinated clause be coreferent with the superordinate subject in English, but not in Kazak? This curious phenomenon is characteristic of other Turkic languages as well (such as Turkish (see Erguvanl1-Taylan 1986)), and it can be explained by the "special character" of Turkic overt pronouns. What concerns us here is that the reference of overt pronominal subjects in embedded clauses is always disjoint from the matrix clause's subject, regardless of the subordinated clause's position, i.e. whether it precedes the whole matrix clause, or it is an other position (e.g. following the matrix subject etc.).

[pro ${ }_{\mathrm{i} / \mathrm{j}}$ Yй-іне кел-ген] соң Айма

[house-POSS.3.DAT come-NF] after Ayša food cook-NNF-DAT start-PAST.3

'After (s)he $\mathrm{i}_{\mathrm{i} j \mathrm{j}}$ came home, Aisha $\mathrm{s}_{\mathrm{i}}$ started cooking.'

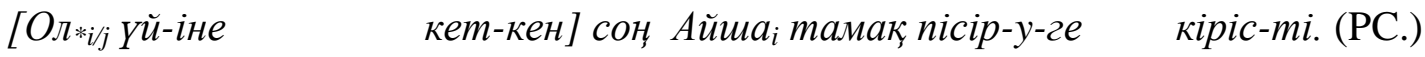

[(s)he house-POSS.3.DAT go-NF] after Ayša food cook-NNF-DAT start-PAST.3

'After (s)he *i $_{\mathrm{i} / \mathrm{j}}$ went home, Aisha $\mathrm{i}$ started cooking.'

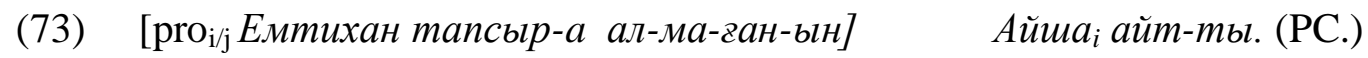

[ exam succeed-A LV-NEG-NF-POSs.3]ACC Ayša say-PAST.3

'It was $\mathrm{Aisha}_{\mathrm{i}}$ who said that (s)he $\mathrm{i}_{\mathrm{i} / \mathrm{j}}$ failed the exam.'

[Оның *і/j емтихан тапсыр-а ал-ма-ван-ььн]

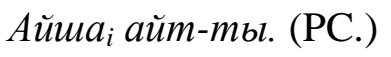
[(s)he exam succeed-A LV-NEG-NF-POSS.3]ACC Ayša say-PAST.3 'Aisha ${ }_{\mathrm{i}}$ said that $(\mathrm{s}) \mathrm{he}_{*_{\mathrm{i}} \mathrm{j}}$ failed the exam.'

To sum up our findings, "cataphora diagnostics", which is used to distinguish between subordinate and coordinated clauses, can be applied in Kazakh as well. However, we have to avoid using the overt pronoun $o l$ '(s)he, it', because, if it is the subject of a subordinate clause, it obligatorily denotes a different referent than the superordinate clause's subject. Thus in 
order to distinguish between coordinated and subordinate clauses, we have to use covert pronominal subjects (pros): in coordinated constructions the first clause's subject cannot be a pro, while in subordinated constructions it can, and it could be coreferential with the superordinate clause's subject.

As a matter of fact, the "cataphora diagnostics" can distinguish between embedded and not embedded clauses: the coordinated clauses that we have presented so far are, naturally, not embedded into the clause they are coordinated with, in contrast to subordinate clauses.

The problem that arises in case of coordinated $-(I) p$-clauses is, however, that coordination does not happen at the full clausal (CP) level. As will become clear shortly, $-(I) p$ may coordinate either VoiceP-s or high light verb phrases, and then these are followed by other functional categories (e.g. Inflection, Tense Copula). That is, the coordinated -(I)pclauses are embedded under mutual functional categories (see the analysis of coordinated -(I)p-clauses below). Thus I suspect that this might affect the applicability of the "cataphora diagnostic".

However, the position of the joint subject of the clauses is still of importance. As will be discussed below, $-(I) p$, if it functions as a coordinator, conjoins VoiceP-s or high light verb phrases. Since the subject's position is in the specifier of IP, which is situated higher in the structure than VoiceP or high light verb phrase, it cannot intervene between the coordinate clauses, but it must precede the coordinated clauses. Consequently, if the subject comes after the $-(I) p$-clause, we can be certain that it is subordinated clause.

This expectation seems to be borne out indeed in light of the following examples. Above in 3.4.2.1, we have shown that in the same examples (with minor modifications) the asymmetrical questions were grammatical, hence we considered the $-(I) p$-clauses in these examples subordinated. Now this claim gets further support, because in these examples the subject comes after the $-(I) p$-clause, suggesting that the matrix clause is an Inflection Phrase, able to host its own subject. Moreover, notice that these -(I)p-clauses have a temporal ((75) and (76)) or a manner (cf. (77)) meaning, which again indicates that they are subordinated.

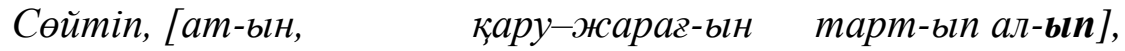
thus [horse-POSS.3.ACC weapon-POSS.3.ACC pull-IP LV.B-CV]

Бек бет-i ау-ван жак-қ̧а қ̧арай жүр-іп кет-еді. (KV, AS)

Bek face-POSS. 3 slide-NF side-DAT towards walk-IP go-PRES.3

'Thus, after he took $\mathrm{his}_{\mathrm{j}} / *_{\mathrm{i}}$ horse and weapons, Bek $\mathrm{i}_{\mathrm{i}}$ went wherever he wished to go.' 
[Ат-қ̧а арба-сын жег-іп],

[horse-DAT cart-POSS.3.ACC load-CV]

[еркек-ше киін-іп] кыз хан-ва кел-еді. (KV, KQMМ)

[man-like dress-CV] girl khan-DAT go-PRES.3

'After its cart was attached to the horse, and she dressed as a man, the girl went to the khan.

(77) Tавы бір күн-дер-де Мұхтар патма-ның алд-ына 의 [он-он бір other one day-PL-LOC Muxtar padishah-GEN front-POSS.3.DAT [ten eleven жас-та-вь екі қзара бала-ны ерт-іп] бір адам кел-іпті. (KV, ВР) year-LOC-ADJ two black child-ACC drag.along-CV] one man come-EVID.3 'Another day a man came to Padishah Muhtar taking two ten, eleven-year-old children with himself.'

\subsubsection{The analysis of coordinated -(I)p-clauses}

Before we draw our finial conclusion, it is necessary to address some questions concerning coordinative $-(I) p$-clauses, which is the topic of this section.

It has been observed that constructions similar to the Kazakh coordinative $-(I) p$ clauses exist in other languages as well, for instance in Papuan or Australian Aboriginal languages. To account for these phenomena, in the mid-eighties Foley and Van Valin, following Michael L. Olson, argued for an additional clause linking (i.e. nexus) type, "cosubordination", which was considered to be distinct from coordination and subordination (Foley \& Van Valin 1984: 256-263). As the term indicates, cosubordinated clauses have features characteristic of both subordinate and to coordinated clauses. According to their argumentation, cosubordinated clauses are non-embedded, which makes them similar to coordinated clauses, but they are not specified for (as Foley \& Van Valin calls it) "tense, mood or illocutionary force" by overt tense, mood etc. morphemes. That is, "tense, mood or illocutionary force" is only marked in one of the clauses, and the other clause(s) only bear(s) a special morpheme that indicates the cosubordination. (This is basically the same phenomenon that I call "scope-over" in this work.) According to them, this latter feature distinguishes them from coordinated clauses, and makes them similar to subordinations, since both the 
subordinated and the cosubordinated clauses are dependent of a functional category (i.e. "tense, mood or illocutionary force") that is not overtly marked on them. (Note that in their understanding, coordinated clauses are independently specified for tense, aspect etc. That is, they consider examples such as (31) cosubordinated (Foley \& Van Valin 1984: 257-260; Foley 2010: 28-29).)

However, in his more recent papers Foley (2010) abandoned the nexus type cosubordination, and proposed to analyze the constructions previously labelled cosubordinated as coordinated, but not on the full clausal (CP), but on a lower level. This is the approach we are going to adopt here in the case of coordinated $-(I) p$-clauses.

Turning to Kazakh, recall that it was argued in 3.3 that there are two structural positions in which -(I)p can be situated: one position is low (following VoiceP), the other is high (following high light verb phrases). In this section, I am going to argue that this also holds for coordinative $-(I) p$, that is it can coordinate VoiceP-s and high light verb phrases as well.

Evidence that coordination on the level of VoiceP is possible comes from the scopeover phenomenon in case of negation and of high light verbs.

It is clear that the Kazakh negative suffix $-M A$ - is situated low in the derivation, coming after VoiceP or, if present, after $\mathrm{v}_{\mathrm{Ben}} \mathrm{P}$ (i.e. the Benefactive light verb Phrase) (cf. Chapter 2). In some examples above, repeated here for the reader's convenience, the scope of the negative suffix - $M A$ - extends over the -(I)p-clause as well.

(78) Ең жақ̧сы қ̧асиет-i- [[ешкім-мен [төбелес-іn],

SUPL good quality-POSS.3 [[nobody-INSTR [fight-CV]

сөз-ге кел]-ме-йтін- $i \quad$ еді]. 20/17 (Q2)

word-DAT come]-NEG-NF-POSS.3] COP.PAST.3

'His/Her best quality was that (s)he wasn't such who would fight or argue with anyone.' 
Айналасындавы елді мекендерді ауыз сумен құмтамасыз етіп отырван Бивако көлінде мұндай феномен пайда болады

den [ешкім [[болжа-n] бақ]-па-ван еді]. (M/N-AA)

DISC.PART [no one [[guess-CV] forsee]-NEG-PERF COP.PAST.3]

'No one had guessed or foreseen that this phenomenon would happen at Bivako lake, which was providing the settlements in the region with drinking water.'

In addition to the scope of negation, the scope of high light verbs may also extend over verb phrases connected by $-(I) p$. In (80), the Benefactive light verb -(I)p al- scopes over both žaygas- 'to settle' and otïr- 'to sit, sit down'. ${ }^{64}$ As shown in Chapter 2, the Benefactive is even lower in the derivation than the negative head $-M A-$, since it attaches to VoiceP-s. The fact the Benefactive can scope over the coordinates indicates that both of them are indeed VoiceP-s.

[Екеу-міз [[жайвас-ып] отыр]-ып ал-ып] днугімелес-е бер-ген-іміз-де [two-POSS.PL1 [[settle-CV] sit]-IP LV.B-CV] chat-A LV-NF-POSS.PL1-LOC Тимка-ның, „Назат!” де-ген қ̧атты айвай-сы есті-л-ді. (M/N-G̈M) Tịmka-GEN "Nazat!” say-NF strong shouting-POSS.3 hear-PL-PAST.3

'When/After we sat and settled down and started chatting, Timka's loud shouting was to be heard, saying "Nazat!".'

Thus we have shown so far that the final verb phrase of the coordinated verb phrases is a VoiceP, since the Benefactive -(I)p al- and the negative -MA-could be attached to it. But how can we make claims about the preceding verb phrase coordinates?

Huddleston \& Pullum (2006: 200-204) argue that only those items can be coordinated which are grammatical in that particular syntactic position on their own as well. (This a more accurate formulation of the well-known observation that items of the same type can be coordinated (Haspelmath 2007: 1), i.e. noun phrases with noun phrases, prepositional phrases with prepositional phrases, etc. As Huddleston \& Pullum point out, not only 'likes' can be

\footnotetext{
${ }^{64}$ In this example -(I)p conjoins two verb phrases that are synonymous. In fact, this is a quite common usage of coordinative $-(I) p$, but by no means the only possible one. There were several examples above where $-(I) p$ coordinated non-synonymous verb phrases.
} 
coordinated, ${ }^{65}$ nevertheless the coordinates have to be able to stand on their own in that particular syntactic position.) Based on this cross-linguistic tendency, we could conclude that the first (or any preceding) coordinate clause must be a VoiceP if the last verb phrase is a VoiceP, since in that particular syntactic position (i.e. preceding the Benefactive) only VoiceP-s are grammatical.

Thus so far we have established that the coordinative $-(I) p$ can be situated in the low structural position, coordinating VoiceP-s. The following tree represents this lower coordination structure. Note that I follow Johannessen in analyzing Conjunction Phrases (\&P-s): she argues that in head-final languages the Conjunction head takes the first conjunct as its complement, and the second conjunct is the specifier of the Conjunction Phrase. Then the features of the conjunct in the specifier position are projected to the level of the Conjunction Phrase (Johannessen 1996: 670-671), hence higher verbal functional categories can select for it. (In the tree, FP stands for further verbal functional phrases that follow NegP.) However, a caveat is in order: such an analysis supposes that specifiers of Conjunction Phrases are right branching in head-final languages. However, this is inconsistent with the position of specifiers, which is left-branching, in all other phrases.

\footnotetext{
${ }^{65}$ Consider the following example, quoted from Huddleston \& Pullum (2006), where a noun phrase and a clause are coordinated, i.e. two items which are not of the same type.

(i) I can't remember [[the cost] or [where I bought it].]
} 
(81) Lower coordination structure

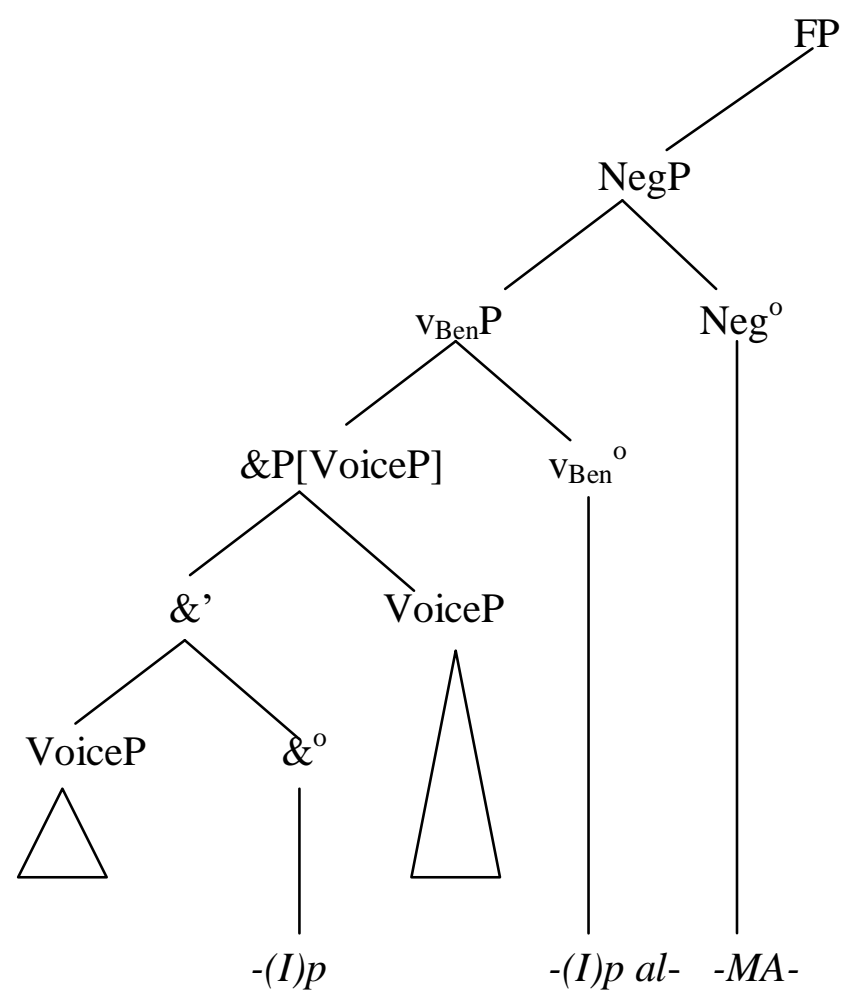

As it was shown in 3.3, -(I)p can also be situated in a higher structural position (in the Inflection slot) following the high light verb phrases. Coordinative $-(I) p$ is no exception. To support this claim, we can yet again turn to the high light verbs for evidence. We will see that coordinative -(I)p can embed high light verbs as well, which indicates that in those cases $-(I) p$ attaches high in the derivation, i.e. it is in the Inflection slot. Consider the following example: first of all, we can be sure that the clauses "Olar urlïq-pen kün kör-ip žür-" and "qüz žalïn-dï dep, qoy-a ber-ip ž̈̈r-” are coordinated, because the scope of the relative clause head - $\dot{G} A n$ extends over both of the clauses. Having established that the clauses involved are coordinated, we can take a look at the predicates of these clauses: both of them contain a Continuous high light verb phrase (-(I)p žür-). Moreover, notice that $-(I) p$ follows the Continuous high light verb in the first clause. 
[[Олар ұрлық-пен күн көр-іп ж⿻ү一-in], қ̧ыз жалын-ды деп, [[they pillage-INSTR day see ${ }^{66}$-IP LV.CONT-CV] girl beg-PAST.3 DISC.PART қоя бер-іп жүр]-ген ұры-лар жомарт. (KV, TÜU)

let.go.A LV-IP LV.CONT]-NF thief-PL generous

'The thieves who live from pillaging, (but) who, because the girl begged (them), let her go, are generous.'

Since in the above example $-(I) p$ embeds a $v_{\text {Cont }} \mathrm{P}$ (i.e. Continuous high light verb Phrase), we can be sure that it is in the high structural position. Moreover, we see also that the first clause is coordinated with a $\mathrm{v}_{\text {Cont }} \mathrm{P}$, since the Continuous high light verb $\left(-(I) p \check{z} \ddot{u} r_{-}\right)$is present on the predicate of the second clause (qoy-a ber-ip žür- 'let.go-A LV-IP LV.CONT-'). Hence it can be established that coordinative $-(I) p$ can be situated in the higher structural position as well.

The following tree shows these constructions. Note that the second clause is not depicted in detail, only the $\mathrm{v}_{\mathrm{Cont}} \mathrm{P}$ is represented in tree, but it may embed the same functional projections as any other $\mathrm{v}_{\text {Cont }} \mathrm{P}$. Naturally, coordinative $-(I) p$ may conjoin other high light verb phrases (e.g. $\left.\mathrm{v}_{\text {Comp }} \mathrm{P}-\mathrm{s}\right)$; in that case $-(I) p$ is in the same high structural slot as in this tree, the only difference is that $\mathrm{v}_{\text {Cont }} \mathrm{P}$ is unrealized.

${ }^{66}$-INSTR kün kör- is an idiom, which means 'to live on something, subsist on something'. 
(83) Higher coordination structure

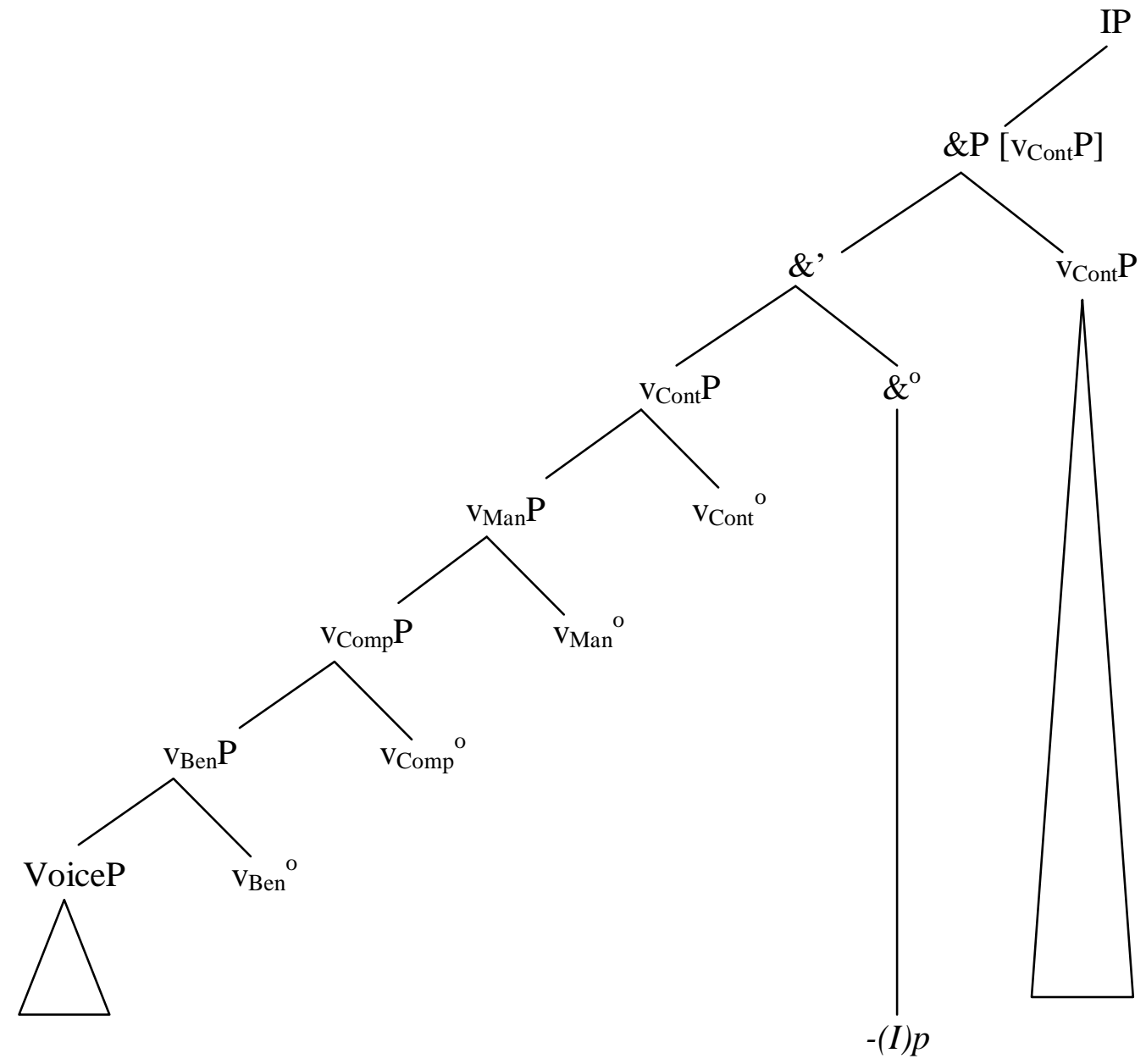

Thus as discussed above, Kazakh -(I)p can coordinate two (or more) VoiceP-s and two (or more) high light phrases; the conjoined items are not full sentences, that is, the coordination does not happen at the full sentential level. Therefore, I claim that in Kazakh coordinative $-(I) p$-constructions the clauses are coordinated not at the sentence level, but lower. This is in line with Foley's (2010: 39-40) claims about Papuan languages, according to which clauses below sentence level can be coordinated too. 


\subsection{The underspecified vocabulary item -(I)p}

In section 3.3 (and also in 3.4.4), it was shown that there are two distinct syntactic positions (low and high) where the non-finite head -(I) $p$ can be situated. It has also been shown that the different meanings (manner vs. temporal/causal) arise as a consequence of the position of the -(I)p-head.

In 3.4 it has been shown that $-(I) p$ can mark subordinated and coordinated clauses as well. Remember that some of the $-(I) p$-clauses are undoubtedly coordinated, since they pattern exactly the same way as "regular" coordinated clauses do. That is, the scope of higher functional categories may extend over these coordinated-(I)p-clauses (cf. 3.4.1.2), symmetrical (question) operations are grammatical in them (cf. 3.4.2.2.1), while asymmetrical operations are ungrammatical (cf. 3.4.2.1.2). On the other hand, other -(I)p-clauses pattern as subordinated clauses: scope-over is not possible in them (cf. 3.4.1.1), asymmetrical operations are felicitous in them (cf. 3.4.2.1.1), but symmetrical operations are not (cf. 3.4.2.2.2), moreover, the subject could come after them (cf. 3.4.3). -(I)p-clauses, under one particular interpretation, are either coordinated or subordinated, they do not exhibit any kind of behaviour that would deviate from "regular" coordinated or subordinated clauses. So it is not necessary to posit a third clause linking type to analyze them.

The peculiarity of these constructions is that four different syntactic configurations (i.e. low and high subordination, low and high coordination) are realized by one and the same vocabulary item, $-(I) p$.

I would be reluctant to posit four homonymous -(I)p-heads with different syntactic functions, thus I propose to treat $-(I) p$ as an underspecified vocabulary item, which can be inserted in all the four above-discussed syntactic positions (i.e. as head of low and high adverb clauses, and low and high Conjunction Phrases). I claim that $-(I) p$ is not specified in terms of the position it must be inserted in the verbal derivation (that is, it can realize syntactic heads that embed VoiceP or $\mathrm{v}_{\mathrm{Cont}} \mathrm{P}$ too), moreover, that it is underspecified in terms of whether it heads a subordinated adverb or a coordinated construction. That is, I assume that the vocabulary item -(I)p has very little feature content. Moreover, a possible explanation why $-(I) p$ can be inserted in all these different syntactic positions might be that all the other vocabulary items are more specified than $-(I) p$, hence their features conflict with the features of these syntactic positions. 
This raises the questions where the interpretation of -(I)p-clauses comes from, and how it is possible that the native speakers were able to differentiate, for instance, between coordinated and subordinated clauses when they were asked for grammaticality judgements about them. I assume that the meaning of the $-(I) p$-marked verb phrase and the matrix predicate, along with the context, have a great part in determining the interpretation of the -(I)p-clause. For example, recall example (79), where the predicates of the $-(I) p$ and the other coordinated clause were 'foresee' and 'guess', respectively. Since the meaning of these verbs is very similar, they are much likelier to be interpreted as being coordinated. On the other hand, in example (48) the $-(I) p$ and the main clause's predicates were 'take away (his weapons and horse)' and 'go away'. Here the event of 'taking away' can easily be conceived as taking place before the 'going away', and this temporal reading is readily combinable with an underlying subordinate structure.

The overall structure of the sentence can affect the interpretation, too: for instance, if the $-(I) p$ and the matrix predicate are not next to each other, or if they have different subjects, the low subordinative (i.e. manner) construction is ruled out. Also, if the subject follows the -(I)p-clause, the coordinative interpretation is not available.

This said, a "regular" -(I)p-clause can very easily be ambiguous. Consider the following example, which was given above, but is repeated here for the reader's convenience. (85) includes two coordinated clauses, which is evident from the scope-over taking place, i.e. the scope of -MAq extends over the üylerine qayt-and the Šigkildekti öltir-clauses as well. (Note that this interpretation is obvious from the discourse in the fairy tale.)

\section{Товыз тоңқылдақ [[үй-лер-іне қ̧айт-ыn],}

Togïz Tonqiildaq [[house-PL-POSS.3.DAT return-CV]

Шіңзкілдек-ті өлтір]-мек бол-адыл. (shortened from: KV, TTBS)

Šijkildek-ACC kill]-PROSP COP-PRES.3

'Togyz Tonkyldak wanted to return to their homes and to kill Shinkildek.' (lit. Togyz Tonkyldak were going to return to their homes and kill Shinkildek.)

However, if we change the context (and the sentence too, to a certain extent), the -(I)p-clause will be interpreted to be subordinated. Consider (86): the -(I)p-cause (üylerine qaytïp 'return to their home') that was interpreted to be a coordinated clause in the previous sentence has a different meaning now. In (86) $-(I) p$ marks a perfective temporal clause, which is 
subordinated to the main clause, and for this reason the scope of matrix functional categories (such as the scope of $-M A q$ ) cannot extend over it.

(86) Тодыз тоңқыллдақ Гүй-лер-іне

қุайm-ыпn], онда ойла-n ойла-n,

Togïz Toyqiildaq [house-PL-POSS.3.DAT return-CV] there think-CV think-CV

Шіңъкілдек-ті өлтір-мек бол-адыл. (shortened from: KV, TTBS; PC.)

Šinkildek-ACC kill-PROSP COP-PRES.3

'Togyz Tonkyldak returned to their home, there they thought and thought, (and then) they decided to kill Shinkildek.'

Thus it is crucial to emphasise that $-(I) p$-clauses are inherently ambiguous, as was illustrated in the above examples, in which the -(I)p-clause $\ddot{u} y l e r i n e ~ q a y t \ddot{p}$ could be assigned at least two different syntactic structures (coordination and high subordination), and consequently two interpretations. Moreover, what determines the interpretation is not the $-(I) p$-head itself, but the context, the meaning of the predicates, and the overall sentence structure. 


\section{Kazakh nominalized and non-nominalized non-finite clauses}

This chapter deals with non-finite clauses that are headed by the morphemes $-w,-\dot{G} A n,-y / A t \operatorname{In}$ and $-(A) r$. The non-finite clauses marked by these suffixes are not restricted to one syntactic position, as, for instance, converb clauses are: converb clauses can only serve as adverbs in the superordinate sentence. In contrast, the non-finite clauses that are the topic of our present chapter can be in argument position, they can be complements of postpositions or semantic cases, moreover they can modify nouns. That is, they have a variety of functions.

The main goal of this chapter is to demonstrate that these non-finite clauses do not form a homogeneous group from a syntactic point of view. I intend to take a closer look at these non-finites, offer criteria to distinguish them, and give a syntactic classification and analysis of them.

This chapter is structured as follows: in 4.1 and 4.2 some introductory remarks will be made on the syntactic positions these non-finite clauses can take and on their lexicalized forms. In section 4.3 a detailed dataset will be given. 4.4 offers an analysis of the data presented in section 4.3 .

\subsection{Introduction}

There are three main positions in which $-w,-(I) s,-M A q,-\dot{G} A n,-y / A t I n$ and $-(A) r$-headed nonfinite clauses can occur:

1. argument position

2. modifier of noun phrases

3. complement of semantic cases or postpositions.

(Many recent works offer a classification based on the syntactic positions of these non-finite clauses in the matrix clause; see Kornfilt 1997: 49-77, throughout Johanson \& Csató 1998, Göksel \& Kerslake 2005: 404-485 etc.)

The third point (i.e. the designation "complement of semantic cases or postpositions") requires some explanation. There is a tradition in the Turkological literature that considers the

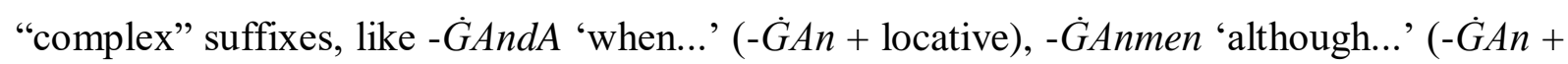
instrumental), or a non-finite head morpheme together with a postposition (e.g. - $\dot{G} A n$ soy 
'after...' ((-ABL) soy 'after')) one undivided unit, usually with the designation "converb morpheme". (Cf. works such as Aydemir 2009, Yüce 1999, throughout Johanson \& Csató 1998 and in other works as well.) This is an acceptable descriptive approach, but from a theoretical point of view it is more insightful not to completely separate argument clauses and clauses, headed by the same suffix, that are the complements of semantic cases or postpositions. ${ }^{67}$ (This approach was inspired by Huddleston \& Pullum's (2006) similar approach to English postpositions and adverbial clauses.) The most important argument in favour of this approach comes from the internal syntactic structure of these non-finite clauses. The $-\dot{G} A n$-head in argument clauses or in complement clauses of semantic cases/postpositions is in the same slot, that is, in the Inflection slot $\left(\mathrm{I}^{\mathrm{o}}\right.$, as addressed in Chapter 2). This is supported by the fact that the non-finite $-\dot{G} A n$-head - no matter what position the non-finite clause is in - can embed exactly the same amount of structure. This is illustrated in the following examples in (1) and (2): in (1) the $-\dot{G} A n$-clause is in argument position (it is the object of the superordinate predicate 'to see'); in (2) the $-\dot{G} A n$-clause is the complement if the (semantic) locative case. Thus the two $-\dot{G} A n$-clauses take a different position in their respective superordinate sentences. However, they embed the same structure, that is they can even embed the $\mathrm{v}_{\text {Cont }}$ Phrase (indicated with bold letters in the examples). Hence $-\dot{G} A n$ in (1) and in (2) must be in the same slot, because they can embed the same amount of structure.

\footnotetext{
${ }^{67}$ Note that I am not going to follow the practice of Kazakh grammars: they deal with the non-finite heads (e.g. Kazakh $-w,-\dot{G} A n,-y / A t I n$ etc.) in two separate chapters: one in the morphology section and one in the syntax section. In the morphology chapter they take a morpheme, $-\dot{G} A n$ for instance, and give all the possible usages, often not indicating in what syntactic position the $-\dot{G} A n$-headed clause is used. Thus they claim that $-\dot{G} A n$ can take the plural $-L A r$ suffix, but not pointing out that it is only possible if $-\dot{G} A n$ heads a headless relative clause (cf. e.g. in Kenesbaev 1962: 321-327). This is illustrated in (i), where the target noun phrase of the - $\dot{G} A n$-headed relative clause is omitted. Note that the omitted noun phrase could be inserted again (e.g. the word 'letter' or 'thing' etc.).

(i) Сен [оның жаз-zан]-дар-ын көр-ді-ц $\quad$ бе? (PC.)

you [(s)he.GEN write-NF]-PL-POSS.3.ACC see-PAST-SG2 Q

'Did you see (the things) that (s)he wrote?'

In the syntax section there is more emphasis on grouping the clauses on the basis of meaning, rather than on syntactic properties.

Since this work is more of a theoretical contribution to the topic, I am going to classify non-finite clauses on the basis of their syntactic positions in the main clause (e.g. argument position, etc.). This is necessary because depending on their position in the superordinate clause non-finite clauses have different syntactic properties. This approach is taken in most of the more recent Turkological works.
} 


\section{(1) [...] [күндіз екі бие бір құлын-ды тең}

[daytime two mare one young-ACC equally

еміз-іп жірақ көр-ген. (KV, ВР)

breast.feed-IP LV.CONT-NF-POSS.3]ACC only see-INDEF.PAST.3

'(They) only saw that in the daytime both mares were feeding one young.'

(2) Мұхтар патша [сол сарай-лар-ды арала-п жүр-ген]-де,

Muxtar sultan [that palace-PL-ACC walk-IP LV.CONT-NF]-LOC

бір ақ талма-льь адам кезіг-іп: [...] (KV, BP)

one white turban-ADJ man come.across-CV

'When sultan Muhtar was walking in those palaces, he came across a man with a white turban $[\ldots]$,

Thus from a theoretical point of view it is not desirable to deal with complement clauses of semantic cases/postpositions, argument clauses and relative clauses as completely separate entities. However, this does not mean that these non-finite clauses would be identical. Evidence from Kazakh and also from other Turkic languages (such as Turkish) supports the validity of the above given classification (based on the position of the nonfinites). The syntactic structure of non-finite clauses seem to differ in accordance with their syntactic position in the superordinate clause.

First let us show the validity of this distinction with the help of Modern Turkish data. In the following, I will only discuss Turkish -DXk-clauses, which can occur in all three positions. In Turkish the agreement with the subject of the non-finite clause is (almost) always $^{68}$ indicated on the $-D X k$-head. If the $-D X k$-clause is in argument position, and if its subject is specific, it bears the genitive case, shown in (3). Note that the non-finite clause is assigned the accusative case by the main predicate ( $g \ddot{o r}$ - 'to see').

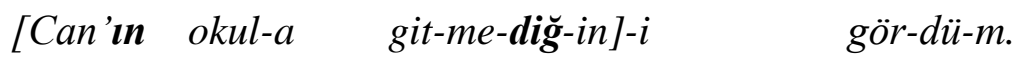

[Can-GEN school-DAT go-NEG-NF-POSS.SG3]-ACC see-PAST-SG1

'I saw that Can didn't go to school.'

\footnotetext{
${ }^{68}$ The exceptions are -DXktAn sonra (the postposition sonra 'after' takes the -DXk-clause as its complement and assigns the ablative $-D A n$ case to it) and $-D X k c ̧ A$ (the $-C A$ equative suffix takes $-D X k$ as its complement) complex heads, expressing 'after...' and 'the more... the more', respectively (cf. Göksel \& Kerslake 2011: 271).
} 
If - $D X k$ heads a relative clause, its subject is marked with the genitive case irrespective of the specificity of its subject. This is shown in (4).

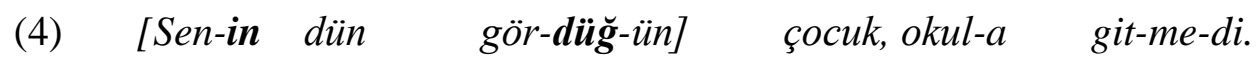

[you-GEN yesterday see-NF-POSS.SG2] child school-DAT go-NEG-PAST.SG3

'The child who you saw yesterday did not go to school.'

However, the subject of $-D X k$-clauses is in the unmarked case (Kornfilt analyzes this as default case) if the non-finite clause is the complement of a semantic case (e.g. the locative, the ablative etc.) or a postposition (e.g. beri 'since, for', kadar 'until', sonra 'after' etc.). ${ }^{69}$ In sentence (5) the -DXk-clause is the complement of the semantic locative case - $D A$. Notice that the subject of the $-D X k$-clause bears unmarked case.

[Can okul-a git-tiğ-in]-de ben onu pencere-den izle-di-m.

[Can school-DAT go-NF-POSS.SG3]-LOC I he.ACC window-ABL watch-PAST-SG1

'When Can went to school, I was watching him from the window.'

This pattern is described in many works, such as in Kornfilt (1997: 68), Kornfilt (2001), Göksel \& Kerslake (2011: 267), etc.

Consequently we can conclude that the case-marking of the subjects of - $D X k$-clauses depends on the position of the non-finite clause in the main clause: if the -DXk-clause is in argument position or is the modifier of a noun phrase, its subject will be marked by the genitive, but if the $-D X k$-clause is the complement of a semantic case or a postposition, its subject will be in the unmarked case. The evidence of these patterns proves that it is indeed necessary to treat the non-finite clauses in these three syntactic positions separately.

Evidence will be given in 4.3 that the Kazakh data also support this distinction.

\footnotetext{
${ }^{69}$ The exceptions are the non-finite clauses with "comparative semantics". For a more detailed explanation see Kornfilt (2001: 77-78), Kornfilt (2003: 169-172).
} 


\subsection{Non-finite clauses and deverbal nominals}

Before we turn to the discussion of the non-finite clauses in Kazakh, an important distinction has to be made (pointed out e.g. in Johanson (1975), Kornfilt (2001), Csató (2010: 110)): namely the distinction between non-finite clauses and deverbal nominals.

\subsubsection{Deverbal nominals}

Kazakh descriptive grammars usually list the following suffixes as formatives of deverbal nominals (my aim here is not to give an exhaustive list, only to mention the more frequently used ones): - $\dot{G} I \check{s},-\dot{G} I,-(I) \check{s},-(I) s,-(I) q,-(A) q,-L A q,-\dot{G} A q,-M A q,-M A,-(I) m,-\dot{G} I n,-M I s$ (Kenesbaev 1962: 141-145; Ysqaqov 1964: 218-230; Qapasova 2004: 59). For a more extensive list see Ysqaqov (1964: 218-230). Here are some examples with these:

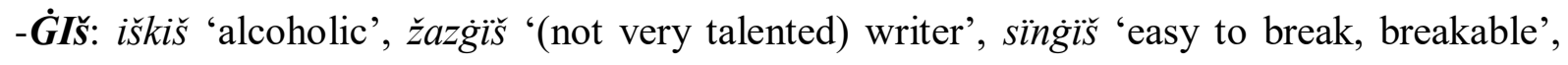
tojazïtqïs 'refrigerator', eskertkiš 'statue', taratqï̌s 'transmitter'

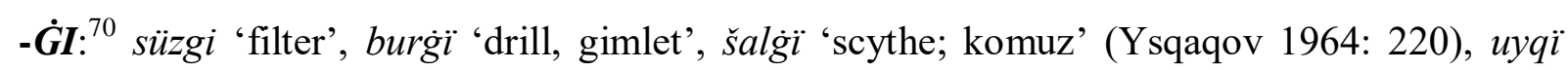
'sleep'

-(I)š: ökiniš 'regret, sorrow'

-(I)q: žetik 'expert, competent person', ušiq 'herpes, fever blister'

-(A)q: bölek 'separate'

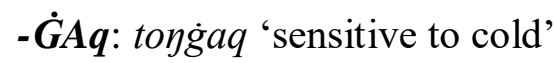

\footnotetext{
${ }^{70} \mathrm{I}$ am not discussing $-\dot{G} I$-headed clauses here. The reason for this is that as a non-finite head - $\dot{G} I$ can only be used as the complement of the auxiliary kel- (in its non-auxiliary usage it means 'to come, go, arrive'). The construction - $\dot{G} I+$ possessive kel- expresses 'want to do something'. The agreement can only be marked on the predicate of the $-\dot{G} I$-clause, the auxiliary is always in $3^{\text {rd }}$ person singular/plural form. An example is given in (i).

(i) Біз-дің тамақ ім-кі-міз кел-еді.

we-GEN food drink-GI-POSS.PL1 AUX-PRES.3

'We want to eat.'

Note that in other Turkic languages in the region the usage of $-\dot{G} I$ as a non-finite head seems to be more common: for example, in Kirgiz the suffix -DAy/DOy ('like, similar to') can join the $-\dot{G} I / \dot{G} U$ head, and they head adjunct non-finite clauses (Kasapoğlu Çengel 2005: 302).

(ii) Bala-m, [jööjür-gü]-döy al qal-ba-dï men-de. (Kasapoğlu Çengel 2005: 302) child-POSS.SG1 [walk.CV go-NF]-like condition stay-NEG-PAST.3 I-LOC

'My child, I don't have strength to go on foot.'

But Kirgiz $-\dot{G} I / \dot{G} U$ can also be combined with $-s I z / s U z$ (>-GIs/GUs '(for an action) not to do') (Kasapoğlu Çengel 2005: 302-303) and with -čA/čO (-GIčA/GUčA 'until') (Kasapoğlu Çengel 2005: 316).
} 
-MA $:^{71}$ bastama 'initiative', qoyma 'treasury', bölme 'room', uytqïma 'strong wind', basqarma 'administration, government', habarlama 'notification; ad', anïqtama 'explanation; information (for tourists)', üyirme 'circle', žoldama 'referral (given by a doctor)'

-MIs: bolmïs 'existence', qülmïs 'crime', turmïs '(family)life, living', žazmï̌ 'fate', oymïs 'engraving in wood, bone or stone ${ }^{, 72}$

-(I)m: bölim 'department, compartment', ölim 'death'

-̇ंIn: qašqün 'runaway, fugitive', tutqün 'prisoner, captive', šapqün 'attack' (Ysqaqov 1964: 226)

The great majority of the above mentioned morphemes cannot head (non-finite) clauses; they can only form nouns with a verbal "core". A number of criteria distinguish these units from non-finite clauses. Kornfilt (2001: 67-70) proposes some Turkic specific criteria distinguishing non-finite clauses from deverbal nominals. These include pluralisation: deverbal nominals can be pluralised, but (usually ${ }^{73}$ ) not the predicates of non-finite clauses. The nouns in (6) (basta-ma: marked with the morpheme -MA) and in (7) (žaz-gižs: marked with $-\dot{G} I \check{S}$ ) bear plural marking.

Бастама-лар қ̧анат каz-ады. (РС.)

initiative-PL wing hit-PRES.3

'The initiatives are launched.'

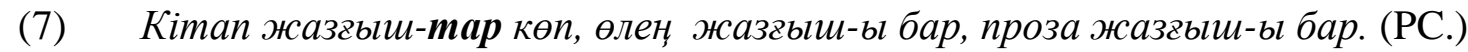

book writer-PL many poem writer-CM exist prose writer-CM exist

'There are many book writers: there are poem writers and prose writers.'

Moreover, deverbal nominals can have a determiner, unlike non-finite clauses (Kornfilt 2001: 68). Examples (8) and (9) illustrate this.

\footnotetext{
${ }^{71}$ Note that the Kazakh morpheme $-M A$ cannot mark non-finite clauses, only deverbal nominals. This is very different from Modern Turkish, where - $m A$ is widely used as a non-finite head.

72 There are some examples where the suffix $-m I s ̌$ is found (Tomanov 1981: 98), instead of the "regular" form -MIs (the Old Turkic/š/ shifts to /s/ in Kazakh, but apparently this did not happen in these examples). Moreover, note that the phonetics of žazmï̌ is not "Kazakh-like", i.e. the suffix initial should be /b/ (not $/ \mathrm{m} /$ ) following the sound /z/. Kenesbaev (1959: 202) marks this word as "eski" 'old', but it is more probable that it is a later borrowing from an other Turkic language.

${ }^{73}$ In Turkish the $-(y) X s$-head (generally accepted as non-finite head) can pluralize.
} 
Бұл бастама өте қ̧ызық. (РС.)

this initiative very interesting

'This initiative is very interesting.'

(9) Ол жаздыи дарыцды емес. (РС.)

that writer talented COP.NEG

'That writer is not talented.'

Deverbal nominals are modified by adjectives and not by adverbials (Kornfilt 2001: 68), as shown in (10), in which the modifier of the deverbal nominal bastama is an adjective ( $\check{a} a q s i$ 'good').

жсақсы бастама-лар (РС.)

good initiative-PL

'good initiatives'

Kornfilt (2001) gives some more criteria (such as the unacceptability of "suspended affixation" with $-(y) X p$ and the lack of the passive morphology in the deverbal nominals).

\subsection{2 "Non-finite morphemes" in deverbal nominals}

To my knowledge, it is hardly ever pointed out in the "Word formation" chapter of Kazakh grammars (with the exception of the morpheme $-M A q$ ) that the above mentioned morphemes that mark non-finite clauses (i.e. $-w,-\dot{G} A n,-y / A t I n,-(A) r$ etc.) can also mark deverbal nominals. (It is sometimes mentioned in their respective chapters that there exist "lexicalized usages".) However, there are clear cases where these suffixes do not head non-finite clauses but smaller units. (Since this distinction is never made in descriptive grammars, they cannot give an exact description of the non-finite clauses either.) Kornfilt (2001: 67-70) draws attention to the necessity to treat deverbal nominals separately from non-finite clauses.

Below I list some Kazakh deverbal nominals formed with "non-finite morphemes":

-w: basqarw 'administration, government', šolw 'review, survey', žattïg w 'exercise, training', qorgaw 'defence' 
$-\boldsymbol{w}+-$-šI: boyawši 'house-painter', satwši 'seller', žazwši 'writer', aldawši 'liar, fraud', qanawši 'someone who exploits others' (QG: 531-534), žürgizwši 'driver', awdarwši 'translator', meygerwši 'manager', oqwši 'student, reader'

-(I)s: batïs 'west', šïg̈̈s 'east', tabïs 'income, acquisition', qonïs 'settlement', etis 'deverbal suffix' (QG: 527-529), urïs 'battle, war', twïs 'relative' (Ysqaqov 1964: 221), demalïs 'rest, holiday', qurïlis 'constuction; structure', öndiris 'industry'

-MAq: salmaq 'weight'

$-M A q+-\breve{s} I:$ aytpaqš̃ 'by the way'

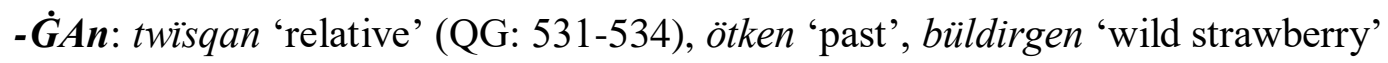

-(A)r: altïatar 'revolver' (QG: 531-534), üygir 'cave, den', šuqür 'pit, hole' (< wұķbl- 'to peck; to carve') (Ysqaqov 1964: 225)

The criteria given above for deverbal nominals can also be applied here. The deverbal nominals formed with these suffixes can be pluralized. An example with šolw 'review, survey' is offered in (11). (The verb šol- means 'to watch, to scrutinize'.)

экономика-льқ шилу-лар (NET-EAC)

economy-ADJ survey-PL

'economic surveys'

In (11) it can also be observed that these items are modified not by adverbials, but by adjectives (ékonomikalïq 'economic' is an adjective). An other example can be found in (12), in which the (deverbal) noun salmaq 'weight' is modified by the adjective menšikti 'own'. (The verb sal- means 'to put; to build (a house); to throw etc.'.)

меншік-ті салмақ

owned.by.himself-ADJ weight

'specific weight' (term in physics)

These deverbal nominals too can have a determiner, such as a demonstrative pronoun. In (13) the deverbal noun žattïg $w$ 'exercise' has a determiner, the demonstrative pronoun bul 'this'. (The verb žattïq- means 'to get used to something'.) 
I argue that in deverbal nominals $-w,-(I) s,-M A q,-\dot{G} A n$ and $-(A) r$ are $\mathrm{n}^{\mathrm{o}}$ heads, i.e. nominal heads, in contrast to non-finite clause heads, for further discussion see 4.4.3.3. In what follows, I am only going to deal with the non-finite clauses headed by these suffixes, and not with the deverbal nominals.

\subsection{Non-finite clauses in three syntactic positions: The dataset}

After discussing deverbal nominals, we can turn to the non-finite clauses. The aim of this subsection is to present the dataset that is going to be analyzed in the following. I treat the data descriptively for now, offering no analysis yet.

The following suffixes can mark non-finite clauses: $-w,-(I) s,-M A q,-A r,-\dot{G} A n,-y / A t I n$ (QG: 527-529, 531-534; Kenesbaev 1962: 320-327). The -GAn, -y/AtIn and -Ar-headed nonfinite clauses can occur in argument position, can be complements of semantic cases or postpositions, or they can modify noun phrases (i.e. they can serve as relative clauses).

The clauses marked by $-w,-M A q,-(I) s$ can occur in "typical" nominal positions, that is, in argument position and as complement of semantic cases or postpositions. (Rarely they can modify noun heads as well. But the syntax of these clauses is quite different from the relative $-\dot{G} A n,-y / A t I n$ and $-(A) r$-clauses. For details see 4.4.3.1.) If the morpheme $-\check{s} I$ combines with $-w(>-w \check{s} I)$ or $-M A q(>-M A q \check{s} I)$, they can modify (agentive) noun phrases. Note that in the following, I will mostly focus on $-w$-headed clauses.

\subsubsection{Non-finite clauses in argument position}

$-w,-\dot{G} A n,-y / A t I n$ and $-(A) r$-headed non-finite clauses can appear in argument position. ${ }^{74}$ In the following table the non-finite heads are listed along with the most relevant syntactic properties of their clauses: the second column gives the case of the subject of the non-finite

\footnotetext{
${ }^{74}$ Note that non-finite clauses appearing in the subject or predicate position in the superordinate clause also belong to this group. So do the non-finite clauses that function as possessors in possessive constructions.
} 
clause, ${ }^{75}$ the third column gives whether it is possible to mark the agreement, ${ }^{76}$ and if it is, where. The forth column indicates that the case assigned by the superordinate predicate is marked on the subordinate predicate. (This is of course expected, since these clauses are in argument position.) The numbers (in the lines) indicate whether the non-finite clause's subject is the same as the superordinate subject ("number 1"), or different from the superordinate clause's subject (“number 2").

\footnotetext{
${ }^{75}$ The subject cases indicated in the tables (14), (39), (55), (56) and (57) are based on the analysis offered in 2.2.

${ }^{76}$ In every type of non-finite clause the agreement marking (where it can be present, at least) is the possessive.
} For the reader's convenience, I repeat the possessive paradigm in (i):

$\begin{array}{lll}\text { (i) } & \text { Sg1. } & -(I) m \\ \text { Sg2. } & -(I) \eta \\ \text { Sg.Formal. } & -(I) \eta I z \\ \text { Sg3. } & -(s) I \\ \text { Pl1. } & -(I) m I z \\ \text { P12. } & (\text { PL })-(I) \eta \\ \text { Pl.Formal. } & \text { (PL) }-(I) \eta I z \\ \text { P13. } & \text { (PL) }-(s) I\end{array}$

Note that SG2 and PL2, SG.FORMAL and PL.FORMAL, moreover SG3 and PL3 morphemes are of the same form. However, when they are attached to noun phrases (and not to non-finite clauses!) the plural suffix (-LAr) can precede the possessive morphemes, indicating that there is more than one possessor. An example is given in (ii):

(ii) олар-дың үй-лер-i

$$
\text { they-GEN house-PL-POSS.3 }
$$

'their house / their houses'

However, the plural $-L A r$ is hardly ever encountered in non-finite clauses. This is a clear difference between noun phrases and non-finite clauses that allow possessive marking. An other difference between noun phrases and non-finite clauses (that allow agreement marking) is that the latter do not allow the dropping of the possessive morpheme. This happens very often colloquially with SG1 and PL1 forms in the case of noun phrases, as shown in (iii).
(iii) біз-дің Казақ̧стан-да we-GEN Kazakhstan-LOC 'in our Kazakhstan'

A similar structure is not grammatical with non-finite clauses, as in (iv).

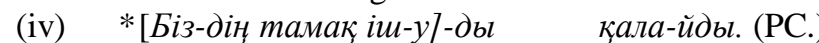 [we-GEN food drink-NNF]-ACC wish-PRES.3
Intended: '(S)he wants us to eat.'

Example (iv) can be corrected if we mark the agreement on the non-finite predicate. 
(14) Syntactic properties of non-finite clauses in argument position

\begin{tabular}{|c|c|c|c|}
\hline Non-fir & $\begin{array}{l}\text { Case of the subject of } \\
\text { the non-finite clause }\end{array}$ & $\begin{array}{l}\text { Is the agreement } \\
\text { indicated, and } \\
\text { where? }\end{array}$ & $\begin{array}{l}\text { Morphemes } \\
\text { following the } \\
\text { clause }\end{array}$ \\
\hline $\begin{array}{l}-\boldsymbol{w} \\
\text { (1. same subject) }\end{array}$ & $1 .-($ & 1. no (obligatorily) ${ }^{77}$ & $\begin{array}{l}\text { cases licensed by } \\
\text { the superordinate } \\
\text { predicate }\end{array}$ \\
\hline $\begin{array}{l}-\boldsymbol{w} \\
\text { (2. different subject) }\end{array}$ & $\begin{array}{l}\text { 2. genitive case / } \\
\text { unmarked genitive case }\end{array}$ & $\begin{array}{l}\text { 2. yes (obligatorily), } \\
\text { following the }-w \text {-head }\end{array}$ & $\begin{array}{l}\text { cases licensed by } \\
\text { the superordinate } \\
\text { predicate }\end{array}$ \\
\hline $\begin{array}{l}-\dot{G} A \boldsymbol{n} ;-\boldsymbol{y} / \boldsymbol{A t I n} ;-(\boldsymbol{A}) \boldsymbol{r} \\
\text { (1a. same subject) }\end{array}$ & 1a. - & 1a. no & $\begin{array}{l}\text { cases licensed by } \\
\text { the superordinate } \\
\text { predicate }\end{array}$ \\
\hline $\begin{array}{l}-\dot{\boldsymbol{G} A n} ; \boldsymbol{- y / A t I n ;} \mathbf{- ( A ) \boldsymbol { r }} \\
(1 \mathrm{~b} . \quad \text { same subject; } \\
\text { "reported speech- } \\
\text { type") }\end{array}$ & 1b. - & $\begin{array}{l}\text { 1b. yes, following the } \\
-\dot{G} A n,-y / A t \operatorname{In} \text { or }-(A) r- \\
\text { head }\end{array}$ & $\begin{array}{l}\text { cases licensed by } \\
\text { the superordinate } \\
\text { predicate }\end{array}$ \\
\hline $\begin{array}{l}-\dot{\boldsymbol{G}} \boldsymbol{A} \boldsymbol{n} ; \boldsymbol{- y} / \boldsymbol{A t I n} ; \boldsymbol{- ( A ) \boldsymbol { r }} \\
\text { (2. different subject) }\end{array}$ & $\begin{array}{l}\text { 2. genitive case / } \\
\text { unmarked genitive case }\end{array}$ & $\begin{array}{l}\text { 2. yes (obligatory), } \\
\text { following the }-\dot{G} A n \text {, } \\
-y / \text { AtIn or }-(A) r \text {-head }\end{array}$ & $\begin{array}{l}\text { cases licensed by } \\
\text { the superordinate } \\
\text { predicate }\end{array}$ \\
\hline
\end{tabular}

If the subject of the $-w$-headed clause is the same as the superordinate clause's, the agreement cannot be indicated. ${ }^{78}$ This is an important property of -w-clauses in argument position; it will be shown below that $-w$-clauses in non-argument positions behave differently regarding the agreement marking. (Note that if the subjects of the subordinate and superordinate clause are the same, the subject can never be indicated in the subordinate

\footnotetext{
${ }^{77}$ The "obligaroty" designation is used when only one agreement marking pattern is possible. If there is no such indication, then there are more possible variants; for example, in case of the $1 \mathrm{~b}$ type of $-\dot{G} A n,-y / A t I n$ and $-(A) r-$ clauses in table (14).

${ }^{78}$ There were three pairs of sentences that belonged to this group in Questionnaire 2. (See sentences (1a)-(1b), (2a)-(2b), (3a)-(3b) in the questionnaire.) In the (b)-variants the agreement was marked. These (b)-variants were rejected by the majority of speakers.

However, note that the sentence (3b) in the questionnaire was accepted by seven speakers (out of twenty). Also some speakers I consulted with claimed that these sentences might be acceptable. It is possible that in these speakers' grammar there is no obligatory control in case of argument $-w$-clauses. Thus we would like to note that there might be a dialect of Kazakh where control is not obligatory in argument -w-clauses. Still, the standard and most widely accepted - version is the one without agreement marking in same subject argument $-w$-clauses.
} 
clause.) In examples (15) and (16) the - $w$-clause is in argument position (it is the object of the superordinate predicate), and the subject of the superordinate predicate (bil- 'to know) and the subordinate predicate (sana- 'to count') is the same (Bürkit), and it is ungrammatical to mark the agreement on the $-w$-headed non-finite predicate (as shown in (16)).

Бүркіт [ақуща сана-у]-ды $\quad$ біл-еді. 20/18 (1 QM) $)^{\mathbf{7 9}}$

Bürkit [money count-NNF]-ACC know-PRES.3

'Bürkit knows how to count money.'

*Бүркіт [ақ̆ма сана-у-ьлн] біл-еді. 20/1

Bürkit [money count-NNF-POSS.3]ACC know-PRES.3

Intended: 'Bürkit knows how to count money.'

The agreement is always marked on the $-w$-headed argument clause if the subordinate and the superordinate clause's subjects are different. This is demonstrated in (17), where the subject of the subordinate clause is first person singular ('I'), and in the superordinate clause it is formal singular ('you (SG.FORML)'). (Naturally, the subject can be dropped if its reference is identifiable.)

\section{[Aüm-y-blм]a рұқ̧сат ет-ің̧із-щі. 20/16 (1 NA)}

[tell-NNF-POSS.SG1]DAT permit LV-IMP.FORML-POL

'Allow me to tell (it).'

So the agreement marking has to be indicated if the argument - $w$-clause's subject differs from the main clause's. Moreover, if there is no agreement marking, the subject of the non-finite clause cannot be in the "unmarked" case. These two properties are very prominent differences between argument and the non-argument $-w$-clauses. In sentence (18) the agreement is not marked on the non-finite predicate, and the non-finite's subject is in the "unmarked" case, rendering the example ungrammatical. ${ }^{80}$

\footnotetext{
${ }^{79}$ The sentences which are followed by numbers (e.g. 20/18) are from Questionnaire 2.

${ }^{80}$ See sentences (4a)-(4b), (5a)-(5b), (6a)-(6b), (7a)-(7b) in Questionnaire 2.
} 
[I tell-NNF]-DAT permit LV-IMP.FORML-POL

Intended: 'Allow me to tell (it).'

If the subject is overt in the -w-clause, it is in the genitive case. (Note, however, that in certain cases it can also be in the unmarked genitive case, i.e. there is no overt case marking on it.) In example (19) the subject of the $-w$-clause is in the genitive (meniy), and the agreement with it is indicated on the non-finite clause's predicate. The $-w$-headed non-finite clause is licensed the accusative case by the superordinate predicate talap et- 'to ask, request'.

Бас дәрігер [менің келісімімсіз химизатор больп

head doctor [I.GEN without.permission laboratory.technician as

жұмыс істе-y-iм]-дi талап ет-іn отыр. (NET-QO)

work do-NNF-POSS.SG1]-ACC request-IP LV.CONT.PRES.3

'The head physician wants me to work as a laboratory technician without permission.'

In contrast to Turkish $-D X k$ and $-(y) A c A k$-clauses, Kazakh $-\dot{G} A n,-y / A t I n$ and $-(A) r-$ headed non-finite clauses in argument position have two subgroups:

1. the $-\dot{G} A n$-clauses that are arguments of verbs such as žaqsï kör- 'like to do something', unat- 'to like' or qala- 'to wish, want'. Two examples are given in (20) and (21).

(20) Қазақ--тар [шәй-дің ылстық, қ̧ою бол-ван-ыл] $\quad$ қุала-йды. (Batayeva 2013: 146) Kazakh-PL [tea-GEN hot strong COP-NF-POSS.3]ACC want-PRES.3

'Kazakhs want the tea to be hot and strong.'

(21) Арыстан [басқару мен басты рөл-де жүр-ген]-ді ұнат-адыл. 20/19 leo [ruling INSTR leading role-LOC walk-NF]-ACC like-PRES.3 'Leo likes being in a leading role.' 
2. the "reported speech"-type of clauses, i.e. those that are complements of verbs such as 'to know (an information)', 'to say', 'to hear' etc. ${ }^{81}$ This group corresponds to the so-called "factive" -DXk or -(y)AcAk argument clauses in Turkish. An example can be found in (22).

(22) [Журнал-дың тагдыр-ы не бол-атын-ьин] [journal-GEN destiny-POSS.3 what COP-NF-POSS.3]ACC алда-вы у уақылт көрсет-ер. 20/17 (1 QM) front-ADJ time show-PROSP.3

'The time before us will show what the destiny of the journal is going to be.'

There are a number of differences between these two groups: first of all, the suffix $-\dot{G} A n$ can be replaced by $-w$ in the first group, but not in the second. In the sentences belonging to the first group the suffix $-\dot{G} A n$ could be substituted by $-w$ : compare the aforementioned (20) and (21) with sentences (23) and (24), respectively. In the latter ones $-\dot{G} A n$ is replaced by $-w$.

(23) Қазақ-тар [шәй-дің, ылстық, қ̧ою бол-у-ын] қала-йды. (РС.)

Kazakh-PL [tea-GEN hot strong COP-NNF-POSS.3]ACC want-PRES.3

'Kazakhs want the tea to be hot and strong.'

(24) Арыстан [басқарумен басты рөл-де жүр-у]-ді Ұнат-адыл. (РС.) leo [ruling INSTR leading role-LOC walk-NNF]-ACC like-PRES.3

'Leo likes being in a leading role.'

In the second group, the replacement of $-\dot{G} A n$ (or $-y /$ AtIn and $-(A) r$ ) with $-w$ is not grammatical. In the following example $-w$ cannot substitute the non-finite head $-y /$ AtIn.

*[Журнал-дың тагдыр-ы не бол-у-ын]

[journal-GEN destiny-POSS.3 what COP-NNF-POSS.3]ACC

алда-вы уақыт көрсет-ер. (РС.)

front-ADJ time show-PROSP.3

'The time before us will show what the destiny of the journal is going to be.'

\footnotetext{
${ }^{81}$ The choice between $-w$ and $-\dot{G} A n(-y / A t I n,-(A) r)$ is lexically determined: some verbs select for $-w$, others for $-\dot{G} A n$.
} 
Secondly, in the "reported speech"-group, even if the subordinate clause's subject is the same as the superordinate clause's, the agreement has to be marked on the predicate of the non-finite clause. Without the agreement marking the sentence is ungrammatical. This is shown in sentences (26) and (27): in (26) the agreement is marked on the predicate of the non-finite clause. The lack of agreement marking renders the sentence ungrammatical, as shown in (27).

Өмірбек [өткен апта Алмать-да бол-ван-ын] айт-тыл. (РС.)

Ömirbek [last week Almatï-LOC COP-NF-POSS.3]ACC say-PAST.3

'Ömirbek said that last week he was in Almaty.'

(27) *Өмірбек [өткен апта Алмать-да бол-ван]-ды айт-тыл. (РС.)

Ömirbek [last week Almatï-LOC COP-NF]-ACC say-PAST.3

Intended: 'Ömirbek said that last week he was in Almaty.'

Another example of the same type is offered in (28). The only difference is that the non-finite head morpheme is the prospective $-(A) r$.

$$
\text { Солжер-де хан [не айт-ар-ын] біл-ме-ді. (KV, TÜU) }
$$
that place-LOC khan [what say-NF-POSS.3]ACC know-NEG-PAST.3

'Then the khan did not know what he was going to say.'

In the first group (i.e. in the non-“reported speech"-type) the agreement marking on the nonfinite predicate results in an ungrammatical sentence if the subordinate and the superordinate clauses have the same subject. This is demonstrated in the following examples: in (29) and (30) the subject of the $-\dot{G} A n$-headed subordinated clause and the main clause is the same ('I'). In (29) there is no agreement marking on the non-finite predicate, and the sentence is grammatical; in (30), however, the agreement is marked, rendering the sentence ungrammatical. 
[mountain-DAT go-NF]-ACC [skate LV-NF]-ACC (like)-PRES-SG1

'I like going to the mountainside (and I like) skating.'

$$
\text { * [Tау-ва бар-ван-ылм]-ды, [коньки теп-кен-ім }]-\partial i
$$

[mountain-DAT go-NF-POSS.SG1]-ACC [skate LV-NF-POSS.SG1]-ACC жақссы көр-е-мін. 20/1

(like)-PRES-SG1

Intended: 'I like going to the mountainside (and I like) skating.'

No one has yet pointed out that - $\dot{G} A n$-type of clauses in argument position have two subgroups. Also note that there is no Turkish equivalent of the Kazakh "first type" (the not “reported speech"-type) of - $\dot{G} A n$-clauses. In Turkish these sentences would only be grammatical with - $m A$-clauses, but not with - $D X k$ (or - $(y) A c A k)$-clauses.

If the subordinate and superordinate subjects are different, there is no difference between the two types, since the agreement has to be marked on the non-finite predicate in both types. ${ }^{82}$ The subject of the non-finite clause can be in the genitive or in the unmarked genitive case. In (31) and (32) the agreement in the non-finite clause is obligatory. In (31) the subject of the $-\dot{G} A n$-clause bears the genitive (bay küyewleri-niy 'his rich sons-in-law + GEN'), but note that it is also possible that the subject is in the unmarked genitive case (as in (32), bay küyewleri(+no overt case) '(his own) rich sons-in-law').

\footnotetext{
${ }^{82}$ Turkish argument clauses basically pattern the same way as Kazakh argument clauses. But note that there are Turkic languages where there are different agreement patterns, such as in Tatar. In Tatar even if the subjects are different, the agreement can be left unmarked, and the subject of the argument non-finite clause can be in the nominative case. This is illustrated by sentence (i), where there is no agreement marking, and the subject ces 'you (PL)' is in the nominative. This would be ungrammatical in Kazakh. In Kazakh, the agreement has to be marked in sentences like in Tatar (i), and the subject can be either in genitive or in nominative. It is noteworthy that in Tatar the strategy in (i) is interchangeable with the one in (ii), where the agreement is marked, and the non-finite's subject is in the genitive. However, if the agreement is indicated, the subject has to bear the genitive (as illustrated by the ungrammatical (iii), where the subject is in the nominative). This too is different from Kazakh, since in Kazakh the subject of an argument clause can bear the nominative case (cf. (32), and $(16 \mathrm{a} / \mathrm{b})$ in Questionnaire 2). (For a more detailed discussion about Tatar non-finite clauses see Georgieva \& Ótott-Kovács (to appear).)

(i) [Сез кил-гән]-не мин кичә $\quad$ Үк ишет-кән иде-м. (Tumaševa 1978: 142) [you come-NF]-ACC I yesterday only hear-PERF COP.PAST-SG1 'I only heard yesterday that you had arrived.'

(ii) [Сез-нең кил-гән-егез]-не мин кичә үк ишет-кән иде-м. (Georgieva \& Ótott-Kovács 2014) [you-GEN come-NF-POSS.PL2]-ACC I yesterday only hear-PERF COP.PAST-SG1 'I only heard yesterday that you had arrived.'

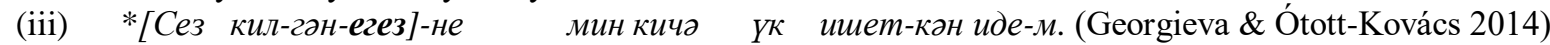
[you come-NF-POSS.PL2]-ACC I yesterday only hear-PERF COP.PAST-SG1 Intended: 'I only heard yesterday that you had arrived.'
} 
Бек [бай күйеу-лер-і-нің киік-тің ет-ін

Bek [rich son.in.law-pl-POSS.3-GEN antelope-GEN meat-POSS.3.ACC

кім-нен ал-ван-ын] айт-ады. (KV, AS)

who-ABL get-NF-POSS.3]ACC say-PRES.3

'Bek told (them) that from whom his rich sons-in-law got the meat of the antelope.'

Өмірбек [өз-і-нің, бай күйеу-лер-і

Ömirbek [self-POSS.3-GEN rich son.in.law-PL-POSS.3

жаз-ван-ылн] айт-адыл. (KV, AS)

heal-NF-POSS.3]ACC say-PRES.3

'Ömirbek said that his own rich sons-in-law healed (him).'

Although $-w$ and $-\dot{G} A n(-y /$ AtIn, $-(A) r)$-headed argument clauses have a lot in common, it does not mean that $-w$ and $-\dot{G} A n$ (or $-y / A t I n$ and $-(A) r$ ) clauses are interchangeable. The difference between $-w$ and $-\dot{G} A n(-y / \operatorname{AtIn},-(A) r)$, on a superficial level, can be described as a difference in subjunctiveness vs. factiveness. This distinction can be futher nuanced, but since this is not the main focus of this work, we will leave this issue for futher research.

The head $-w$ is used if the subordinated clause is subjunctive, that is, if it expresses an (indirect) order, advice etc. In the following sentence the $-w$-headed clause expresses an indirect request.

[Хальқь-қ̧а от жақ̆-тыр-ма-у-blң̧ызз]-ды сұра-й-мын. (KV, ZEZET)

[people-DAT fire light-CAUS-NEG-NNF-POSS.FORM]-ACC ask-PRES-SG1

'I ask you not to let the people light a fire.'

Below I list some verbs that (when used in the given meaning) can take an $-w$-clause as their complement; the assigned cases are also indicated.

bil- +ACC 'to be able to do something'

žapa- +DAT 'to be appropriate for doing something'

$q \ddot{i} y$ - +DAT 'meant to be used for something, born to do something, be appropriate for'

qorq- +DAT 'to be afraid of doing something' 
maqsat et- +ACC 'to intend to do something'

The heads $-\dot{G} A n,-y / A t I n$ and $-(A) r$ are used when one tells, reports, requires information etc. about an actual event that will or has already taken place. Here I give some verbs that require a $-\dot{G} A n(-y /$ AtIn or $-(A) r)$-headed clause if they are used in the given meaning. I also include the case assigned to the clause.

ayqïndal- 'to become clear that...'

ayt- +ACC 'to say that...'

ayïr- +ACC 'distinguish that...'

bil- +ACC 'to know that...'

esti- +ACC 'to hear that...'

$k \ddot{o r}-+\mathrm{ACC}$ 'to see that...'

qara- + ACC 'to watch something happening'

moyïna al- +ACC 'to admit doing something, to confess'

razï bol- +DAT 'be satisfied with an event'

sez- +ACC 'to feel something, to be aware of something'

Note that certain verbs can occur with both types of non-finite clauses (but the verb has different meaning depending which clause it occures with). Bil- is such a verb: if it occurs with a $-\dot{G} A n$-headed subordinate clause, it expresses 'to know that..., to have knowledge about (an event)', as illustrated in (34).

Біреу-іміз [алтын-күміс-тіңқ қ̧ай жер-де

one-POSS.PL1 [gold-silver-GEN which place-LOC

жат-қан-ьлн] біл-е-міз. (KV, QP)

lie-NF-POSS.3]ACC know-PRES-PL1

'One of us knows where the gold and silver is.'

However, if bil- co-occurs with a -w-headed clause, its meaning is 'to be able to (do something)', cf. (35). 
Патша [даульь түйе-ні құайсы-сына

padishah [debated camel-ACC which-POSS.3.DAT

бұйыр-ыл бер-y]-дi біл-ме-ді. (KV, ВР)

command-IP LV.B-NNF]-ACC know-NEG-PAST.3

'The padishah was not able to decide who to give the camel in question.'

\subsubsection{Non-finite clauses modifying nouns}

In addition to $-\dot{G} A n,-y / A t I n$ and $-(A) r$-headed clauses, $-w$-clauses can also modify nouns. Let me address first the latter clause-type very shortly. $-w$-clauses can modify noun heads, and if they do, the compound marker $-(s) I$, which appears to be the same as the $3^{\text {rd }}$ person possessive marker, shows up on the noun head. This is shown in example (36): the $-w$-clause modifies the noun head žumïs 'work', and the compound marker is indicated on the modified noun head (in bold). For a more detailed discussion see the 'Nominalized clauses' revisited part of this chapter.

[«Коста Конкордиа»кеме-сін көтер-у] жұмыс-тар-ы

[Kosta Konkordia ship-CM.ACC raise-NNF] work-PL-CM

аяқтал-ды. (NET-24KZ)

be.finished-PAST.3

'The works of lifting the ship Costa Concordia have come to an end.'

Relative clauses, i.e. clauses that modify noun phrases, are formed with $-\dot{G} A n,-y / A t I n$ or -(A)r-headed non-finite clauses (Kenesbaev 1962: 186-187). These clauses modify noun phrases, and not noun heads (in contrast to -w-clauses). Kazakh relative clauses are always non-finite, and they precede their target (the noun phrase they modify). In Kazakh relative clauses there is a "gap" corresponding to the target of the relativization. In example (37) the target is adamdar 'men', and there is a gap corresponding to it in the relative clause (marked with Ø). Filling in this gap with a noun phrase would lead to an ungrammatical sentence, or to a very different meaning - as it can be seen in (38), where the gap is filled with an other direct object, resulting in a different interpretation. 
Ол [Ø жібер-ген] адам-дар

that [send-NF] man-PL city-ABL

бір диуана адам-ды ал-ыл кел-еді. (KV, ZEZET)

a mad man-ACC take-CV come-PRES.3

'Those men who were sent brought a dervish from the city.'

(38) [Олар-ды

[they-ACC send-NF] man-PL city-ABL

бір диуана адам-дыл ал-ьлп кел-еді. (PC., based on KV, ZEZET)

a mad man-ACC take-CV come-PRES.3

'The men who sent them brought a dervish from the city.'

It is a well-known fact that languages often apply different strategies in relative clauses depending on the target's grammatical role in the relative clause (Keenan \& Comrie 1977). In Kazakh, the selection of the head morpheme (i.e. $-\dot{G} A n,-y /$ AtIn or $-(A) r)$ does not depend on the target's grammatical role (or to be more precise: the gap corresponding to the target). For this reason, it is possible that a relative clause is ambiguous between the "subject relative" and the "non-subject relative" interpretation. The choice between the $-\dot{G} A n,-y / A t I n$ or $-(A) r$ non-finite heads is based on the aspectual properties of these heads.

In the table below I summarize the relevant syntactic characteristics of Kazakh relative clauses: in the second column I indicate the case of the subject of the relative clause and in the third column the agreement marking - if there is any, and the placement of the agreement marking. No morphemes can be added to RCs; only headless relative clauses could be followed by suffixes attaching to the predicate of the relative clause. But in this case the attached morphemes actually attach to the omitted noun phrase, not to the relative clause. 
(39) Syntactic properies of relative clases

\begin{tabular}{|l|l|l|}
\hline Non-finite head & $\begin{array}{l}\text { Case of the subject of the } \\
\text { non-finite clause }\end{array}$ & $\begin{array}{l}\text { Is the agreement indicated, } \\
\text { and where? }\end{array}$ \\
\hline $\begin{array}{l}\text { 1. }-\dot{G} A n ;-y / A t I n ;-(A) r \\
\text { (subject RCs) }\end{array}$ & $\begin{array}{l}- \text { (the RC's subject is the } \\
\text { target of the relativization) }\end{array}$ & no (obligatorily) \\
\hline $\begin{array}{l}\text { 2a. }-\dot{G} A n ;-y / A t I n ;-(A) r \\
(\text { non-subject RCs) }\end{array}$ & nominative case & no \\
\hline $\begin{array}{l}\text { 2b. }-\dot{G} A n ;-y / A t I n ;-(A) r \\
\text { (non-subject RCs) }\end{array}$ & genitive case & $\begin{array}{l}\text { yes, on the target of the } \\
\text { relative clause }\end{array}$ \\
\hline
\end{tabular}

\subsubsection{Subject relative clauses}

If the target of the relativization is the subject of the relative clause, the agreement cannot be indicated. In (40) the target of the relative clause ( $\chi$ an 'khan') is the subject of the clause (the 'khan' is the one who lives in a town); it would lead to ungrammaticality to mark the agreement with this subject. (Note that in (40) the suffix $-y /$ AtIn is used, because the action is habitual.)

\section{Мен [бір шәрі-де тұр-атын] хан-ныңң бала-сы}

I [a town-LOC live-NF] khan-GEN child-POSS.3 COP.PAST-SG1

'I was the child of a khan who lives in a town.'

If the predicate of the relative clause is an intransitive verb, it is easier to avoid ambiguity between the subject and the non-subject relative clause interpretation. In (40) the target of the relative clause is the subject of the clause (the khan is the one who "performs" the action of living), and because the predicate of the $\mathrm{RC}$ is intransitive (tur- 'to live, to stand'), the only viable interpretation is that he is the subject. A similar example is given in (41), where the predicate of the relative clause bears the passive allomorph -il (žiber-il- 'high light verb + passive'), and the target is the subject of the clause (i.e. the girl was the one who has been driven away from the town). 
this [town-ABL drive.away-IP LV.C-PASS-NF] girl

'This is the girl who was driven away from the town.'

For examples where the predicate of the clause is intransitive, but the target expresses location or time etc. (i.e. they occupy the adverb position in the RC), see the examples in (48) and (49).

If the predicate of the relative clause is a transitive verb, the target can be interpreted as the subject or as not the subject (e.g. the object) of the RC. Thus these clauses are ambiguous between the subject or non-subject interpretation.

However, there seems to be a commonly used strategy to avoid this ambiguity: if the target of the relativization is the subject of the $\mathrm{RC}$ that has a transitive predicate, the direct object is present in the relative clause. Thus the ambiguity is avoided. (Recall the sentence in (37): without any context the phrase žibergen adam could be ambiguous between 'the man who was sent' (non-subject relativization) and 'the man who sent (someone); the sender man' (subject relativization) meanings. Thus under the 'the man who sent (someone/them)' meaning the olardï žibergen adam will be preferred. In my corpus the direct object was present in practically all subject relatives where the predicate of the RC was a transitive verb, or if not, it was clear from the context that there has to be an object in the clause. Sentence (42) would have two interpretations if we left out the direct object (meni 'me'): the subject relative interpretation that is 'the enemy that stabbed someone' or the non-subject relative interpretation where 'the enemy who was stubbed (by someone)'. But since the direct object is present, there is only one way to understand this sentence, the former one.
[Mені шап-қ̧ан] жау анау! (KV, KQMМ)
[I.ACC stab-NF] enemy that

'That is the enemy who stabbed me.'

\subsubsection{Non-subject relative clauses}

There are two patterns in non-subject relative clauses: the agreement can be left unmarked (and the subject is in the nominative case); or the agreement is marked, but not on the predicate of the $\mathrm{RC}$, but on the target of the relativization (and the subject of the $\mathrm{RC}$ is in genitive). These two strategies are interchangeable under the right circumstances. 
First, I will discuss the instances where there is no agreement marking. The subject, if overt, is in the nominative case. In example (43) there is no agreement, and the subject (men ' $\mathrm{I}$ ') of the non-finite clause is in the nominative case.

...осы [мен ұста-п тұр-ван] ииша-ва кір-іп кет-е-сіңдер. (KV, BР)

this $\quad[\mathbf{I}$ hold-IP LV.CONT-NF $]$ bottle-DAT go.in-IP LV.C-PRES-PL2

'...you will slip into this bottle I am holding in my hand!'

The most curious construction is the one where the agreement with the relative clause's subject is indicated, but not locally, i.e. not on the predicate of the non-finite clause (as it was the case in argument clauses), but on the noun phrase that the RC modifies. The subject of the relative clause (if overt) is genitive-marked. An example is given in (44). The agreement can be found on the target noun phrase (et-i 'meat + POSS.3'), and the subject of the non-finite clause bears the genitive ( $\chi$ an-n̈̈y 'khan + GEN').

[Хан-ның біз-ге бер-ген] ет-і ит-тің ет-і екен. (KV, TÜU)

[ $\chi$ an-GEN we-DAT give-NF] meat-POSS.3 dog-GEN meat-POSS.3 COP.EVID

'The meat that the khan gave (us) was apparently the meat of a dog.'

From a theoretical standpoint this latter case is especially curious, because the agreement is excepted to be marked locally, i.e. in the same clause. This is clearly not the case in (44), because the agreement marker is not on the predicate of the RC.

Note that there is no "possessive semantics" between the subject of the RC and the agreement-marked noun phrase. This is demonstrated in (45), where the subject of the relative clause is genitive-marked (seniy 'you.GEN') and the agreement is found on the target of the relativization (Aisha), but it is not the case that Aisha is owned by 'you'. Hence there is no "possessive semantics".

[Сенің көр-ген] Айша-ц жақ̆сы студент. (РС.)

[you.GEN see-NF] Ayša-POSS.SG2 good student.

'Aisha(,) who you saw is a good student.' 
If the subjects of the RC and the superordinate clause are the same, the agreement is generally not indicated, and it is not possible to repeat the subject in the subordinate clause. In example (46), in which the RC's subject is the same as the superordinate clause's, the agreement is not marked.

[Анадай жер-де ұста-п тұр-ван] екі інген-ді

[that place-LOC hold-IP LV.CONT-NF] two she.camel-ACC

қоя бер-іңдер деп бұйыл-ылтmы. (KV, BP)

set.free.A LV-IMP.PL2 DISC.PART order-EVID.3

'He ordered that they set free the two she-camels that they were holding at that place.'

However, it is also possible that the agreement is marked, even if the subjects of the RC and the superordinate clause are the same. In example (47) the subjects of the RC and the superordinate clause are the same ('you'), nevertheless the agreement is indicated on the

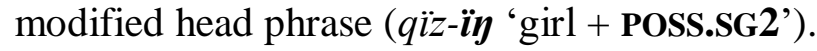

[Сүй-ген] қызы-ыца үйлен. (РС.)

[love-NF] girl-POSS.SG2.DAT marry.IMP.SG2

'Marry the girl you love.'

In all the examples above, the target of the relativization was the object of the RC. It is possible to relativize other parts of the clause, for example adverbs or indirect objects. The following sentence offers an example: the modified noun phrase is tawlar 'mountains'; this phrase has an adverbial role in the relative clause (it is the place where the deer walk).

Адам-дар сахара-zа шыз-bln,

people-PL desert-DAT go.out-CV

[киік жүр-етін] тау-лар-ды қ̧ама-n ал-ьıпты. (KV, ZEZET)

[deer walk-NF] mountain-PL-ACC surround-IP LV.B-EVID.3

'People went out to the desert and they surrounded the mountains where the deer walk.'

Naturally, it is possible to mark the agreement it this case as well. This is shown in (49). 
[Бұлар-дың жат-қ̧ан] жер-ін-де

[this.PL-GEN lie-NF] place-POSS.3-LOC

жеті патша-ның мал-ьы

бар. (KV, KQMM)

seven sultan-GEN property-POSS.3 exist

'In the place where they are lying, the treasure of the seven sultans is hidden.'

\subsubsection{Headless relative clauses}

The target of the RC can be omitted. If so, all inflectional suffixes that would attach to the noun phrase attach to the predicate of the RC. For example, the plural, the agreement, or the case suffixes. (Note that only in this case can the agreement marking appear on the predicate of the relative clause.) In example (50) the target is omitted, and the agreement marking and accusative case that would have been marked on the target are attached to the predicate of the relative clause.

Ол [хан-ның қ̧blз-bl-нblң, айm-қ̧ан]-blн

(s)he [ $\chi$ an-GEN daughter-POSS.3-GEN say-NF]-POSS.3.ACC

iсте-п жүр-е бер-еді. (KV, ZEZET)

do-IP LV.C-A LV-PRES.3

'He did what the khan's daughter told (him) to do.'

It is not possible to confuse argument clauses and headless relative clauses, because it is possible to insert a noun phrase (e.g. 'thing') in the latter, but not into the former.

In some rare cases it is possible that the agreement is left unmarked on headless relatives and the subject is in the "unmarked" case, although this does not seem to be always acceptable, in contrast to the agreement-marked strategy which is always grammatical. I will leave it to further research to determine under what circumstances is the former strategy acceptable. In sentence (51) the agreement is not indicated and the RC's subject is in the "unmarked" case; while in (52) the agreement is marked and the subject of the non-finite clause bears the genitive. 
(51) [Ол көр-ген]-ді мен көр-ді-м. (Amanžolov 1994: 193)

[(s)he see-NF]-ACC I see-PAST-SG1

'I saw what (s)he saw.'

[Оның көр-ген-ін] мен көр-ді-м. (Amanžolov 1994: 193)

[(s)he.GEN see-NF-POSS.3]ACC I see-PAST-SG1

'I saw what (s)he saw.'

\subsubsection{An idiomatic usage: $-A \dot{\boldsymbol{g}} A \boldsymbol{n}$}

If used idiomatically, ${ }^{83}$ an /a/ or an /e/ (determined by vowel harmony) can be inserted between the verb stem and the $-\dot{G} A n$ relative head morpheme. (This is mentioned in Menges 1959: 475; Balaqaev \& Isqaqov 1954: 326; Ysqaqov 1967/I: 180.) ${ }^{84}$ Such examples are given in (53)-(54).

көр-еген адам

see-A $\dot{\mathbf{g} A n}$ man

'circumspect person'

Бер-еген құол-ылм ал-аван.

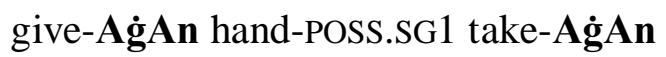

lit. 'The giver hand is (also) a taker (hand).' (Proverb; meaning: those who give get something in return.)

\footnotetext{
${ }^{83}$ An other idiomatically used suffix is $-A z ̌ A q$. In south Kazakhstan it is only used with two verbs al- 'take, get' ber- 'give' (Ysqaqov 1967/I: 180). The following example is quoted from Ysqaqov's work:

(i) Жыл-дық есеп-те мен [100 сом ал-ажақ] бол-ды-м,

year-ADV report-LOC I [100 Som get-AžAq] become-PAST-SG1

ол [100 сом бер-ежек] бол-ды.

(s)he [100 Som give-AžAq] become-PAST. 3

'In the yearly report I was to get 100 Soms, and (s)he was to give 100 Soms.'

${ }^{84}$ This form seems to be somewhat more frequently in other Turkic languages, for example in Bashkir, Kumük (Dimitriev 1940: 156) and in Kirgiz. The literature says that the $-A \dot{G} A n$ expresses habitual action: such as Kirgiz -aagan, -eegen, -öögön-clauses (Kasapoğlu Çengel 2005: 297-298). In Kirgiz it can be mostly found in lexical items, so the suffix is not used to form non-finite clauses anymore. A few examples are given from Kasapoğlu Çengel (2005: 298): kör-öögön 'good-sighted, alert', qabaaġan (< qap-aaġan) 'vicious (dog)', al-aġan 'who takes a lot, greedy'.
} 


\subsubsection{Non-finite complement clauses of semantic cases or postpositions}

This section deals with the $-w,-(I) s,-M A q,-\dot{G} A n,-y / A t I n$ and $-(A) r$-headed non-finite clauses which are complements of semantic cases or postpositions. Since this position (i.e. the complement position of a semantic case/postposition) is a non-argument position, these clauses have different syntactic properties than the argument clauses.

The following tables summarize the most important syntactic properties of these clauses. The tables follow the same arrangement as seen above. The second column gives the case of the subject of the non-finite clause, the third column gives whether agreement is possible or not, and if it is, then where. ${ }^{85}$ In certain cases the agreement can be either indicated or not indicated (the "a" and "b" designations render this distribution). The forth column offers a short description about the "additional element".

\footnotetext{
${ }^{85}$ Very little is said about the possibility to mark the agreement in the literature. (We find some mention to this in Tanç (2002: 148-149) or in Balaqaev \& Isqaqov (1954: 540-541).) So basically all the observations that can be seen below are based on my own research.
} 
(55) Syntactic properties of $-w,-(I) s$ and $-M A q$-headed clauses as complements of semantic cases or postpositions

\begin{tabular}{|c|c|c|c|}
\hline Non-finite head & $\begin{array}{l}\text { Case of the subject } \\
\text { of the non-finite } \\
\text { clause }\end{array}$ & $\begin{array}{l}\text { Is the Agreement } \\
\text { indicated, and } \\
\text { where? }\end{array}$ & $\begin{array}{l}\text { Morphemes } \\
\text { following the clause }\end{array}$ \\
\hline \multirow[t]{2}{*}{$\begin{array}{l}-w \\
\text { (1. same subject) }\end{array}$} & $\begin{array}{l}\text { 1a. - (no overt } \\
\text { subject) }\end{array}$ & 1a. no & \multirow[t]{2}{*}{$\begin{array}{l}\text { certain semantic } \\
\text { cases; postpositions }\end{array}$} \\
\hline & $\begin{array}{l}\text { 1b. } \quad \text { (no overt } \\
\text { subject })\end{array}$ & $\begin{array}{l}\text { 1b. yes; following } \\
\text { the }-w \text {-head }\end{array}$ & \\
\hline \multirow[t]{2}{*}{$\begin{array}{l}-\boldsymbol{w} \\
\text { (2. different subject) }\end{array}$} & $\begin{array}{l}\text { 2a. genitive/ } \\
\text { unmarked genitive }\end{array}$ & $\begin{array}{l}\text { 2a. yes; following the } \\
-w \text {-head }\end{array}$ & \multirow[t]{2}{*}{$\begin{array}{l}\text { certain semantic } \\
\text { cases; postpositions }\end{array}$} \\
\hline & $\begin{array}{l}\text { 2b. unmarked } \\
\text { genitive }\end{array}$ & 2b. no & \\
\hline $\begin{array}{l}-(I) s \\
\text { (same \& different } \\
\text { subject) }\end{array}$ & $\begin{array}{l}\text { unmarked genitive / } \\
\text { genitive }\end{array}$ & $\begin{array}{l}\text { yes (obligatorily); } \\
\text { following the }-(I) s- \\
\text { head }\end{array}$ & -Men (INSTR) \\
\hline $\begin{array}{l}-M A q \\
\text { (same subject) }\end{array}$ & $-($ no overt subject $)$ & no (obligatorily) & $\begin{array}{l}\text { postpositions } \quad \text { üšin } \\
\text { 'for', tügil 'not even' }\end{array}$ \\
\hline
\end{tabular}


(56) Syntactic properties of $-\dot{G} A n$ and $-y / A t I n$-headed clauses as complements of semantic cases or postpositions

\begin{tabular}{|c|c|c|c|}
\hline Non-finite head & $\begin{array}{l}\text { Case of the subject } \\
\text { of the non-finite } \\
\text { clause }\end{array}$ & $\begin{array}{l}\text { Is the Agreement } \\
\text { indicated, and } \\
\text { where? }\end{array}$ & $\begin{array}{l}\text { Morphemes } \\
\text { following the clause }\end{array}$ \\
\hline \multirow[t]{2}{*}{$\begin{array}{l}-\dot{G} A n ;-y / A t I n \\
(1 . \text { same subject) }\end{array}$} & $\begin{array}{l}\text { 1a. }- \text { (no overt } \\
\text { subject) }\end{array}$ & 1a. no & \multirow[t]{2}{*}{$\begin{array}{l}\text { semantic cases, } \\
\text { postpositions }\end{array}$} \\
\hline & $\begin{array}{lll}\text { 1b. } \quad-\quad \text { (no overt } \\
\text { subject })\end{array}$ & $\begin{array}{l}\text { 1b. yes; following } \\
\text { the }-\dot{G} A n \text { or }-y / A t I n- \\
\text { head }\end{array}$ & \\
\hline $\begin{array}{l}-\dot{G} \boldsymbol{A n} ; \boldsymbol{- y / A t I n} \\
(2 \alpha . \text { different subject } \\
-\quad \text { complement } \\
\text { clauses of e.g. -(ABL) } \\
\text { soy 'after', sayïn } \\
\text { 'every' etc. }\end{array}$ & 2a. nominative & 2a. no (obligatorily) & $\begin{array}{lr}\boldsymbol{2 \alpha} . & \text { certain } \\
\text { postpositions } & \text { (e.g. } \\
-(\mathrm{ABL}) \text { soy 'after', } \\
\text { saÿ̈n 'every') }\end{array}$ \\
\hline 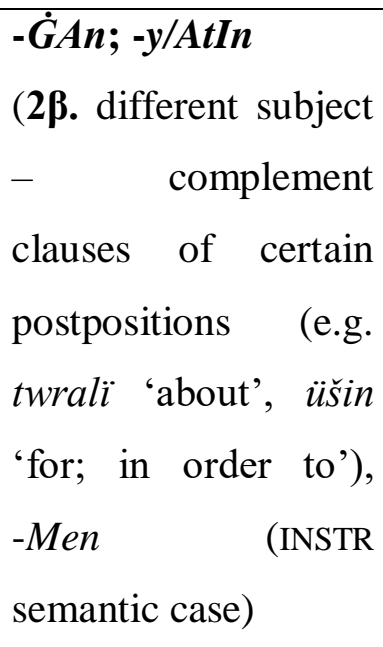 & $\begin{array}{l}\text { 2ß.a. unmarked } \\
\text { genitive / genitive }\end{array}$ & 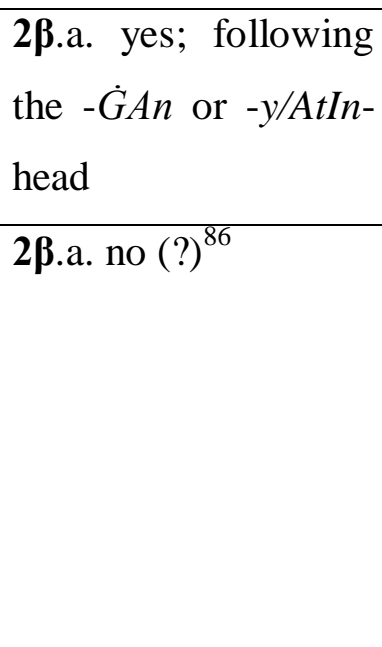 & $\begin{array}{lr}\mathbf{2 \beta} . & \text { certain } \\
\text { postpositions (e.g. } \\
\text { twrali 'about', üšin } \\
\text { 'for; in order to'), } \\
\text {-Men (INSTR } \\
\text { semantic case) }\end{array}$ \\
\hline $\begin{array}{l}-\dot{G} A n ;-y / A t I n \\
(2 \gamma . \text { different subject } \\
-\quad \text { complement } \\
\text { clauses of all the } \\
\text { remaining semantic } \\
\text { cases and }\end{array}$ & $\begin{array}{l}\text { 2y.b. unmarked } \\
\text { genitive / genitive }\end{array}$ & $\begin{array}{l}\mathbf{2 \gamma . b .} \text { yes; following } \\
\text { the }-\dot{G} A n \text { or }-y / \text { AtIn- } \\
\text { head }\end{array}$ & $\begin{array}{l}\mathbf{2 \gamma} \text {. all the remaining } \\
\text { semantic cases } \\
\text { (locative, dative, } \\
\text { ablative, }-\check{s} A,-D A y \text { ), } \\
\text { and the remaining } \\
\text { postpositions }\end{array}$ \\
\hline
\end{tabular}

${ }^{86}$ For the explanation of the "question mark" see the respective section. 
postpositions)

(57) Syntactic properties of $-(A) r$-headed clauses as complements of semantic cases or postpositions

\begin{tabular}{|l|l|l|l|}
\hline Non-finite head & $\begin{array}{l}\text { Case of the subject } \\
\text { of the non-finite } \\
\text { clause }\end{array}$ & $\begin{array}{l}\text { Is Agreement } \\
\text { indicated, and } \\
\text { where? }\end{array}$ & $\begin{array}{l}\text { Morphemes } \\
\text { following the clause }\end{array}$ \\
\hline $\begin{array}{l}-(\boldsymbol{A}) \boldsymbol{r}(\text { and }-\boldsymbol{M A s}) \\
(\text { same \& different } \\
\text { subject })\end{array}$ & nominative no & $\begin{array}{l}\text { locative, dative, } \\
\text { ablative, } \\
\text { semantic cases; the } \\
\text { postpositions } \\
\text { aldinda 'before', } \\
\text {-(ABL) burin } \\
\text { 'before', üšin 'for, in } \\
\text { order to' }\end{array}$ \\
\hline
\end{tabular}

\subsubsection{1 $-w,-(I) s$ and $-M A q$-headed non-argument clauses}

If the subject of the $-w$-clause is the same as the superordinate clause's subject, it is not indicated in the $-w$-clause. In (58) the subject of the $-w$-clause is the same as in the main clause (olar 'they'), hence it is not indicated in the non-finite clause, and there is no agreement marking.

Олар да бұрыи-та отыр-ван мұны көр-іп,

they too corner-LOC sit-NF this.ACC see-CV

[өлтір-у] Ушін қзас-ына кел-еді. (KV, QP)

[kill-NNF] for side-POSS.3.DAT come-PRES.3

'They saw this (person) sitting in the corner, and in order to kill (him), they came to his side.'

Note that in non-argument $-w$-clauses, even if the superordinate subject is the same as in the subordinate non-finite $-w$-clause, the agreement can be marked on the predicate of the $-w$ clause - but it is not obligatory. In example (59) both the superordinate and the subordinate 
-w-clause's subject is the same ('I'), and the agreement is marked on the non-finite predicate (shown in bold). Remember that in argument $-w$-clauses the agreement marking was not acceptable in the same subject sentences. Hence this is a difference between the argument and the non-argument $-w$-clauses.

[Жазыл-у-ым. Уиін тырыс-ыл кел-е-мін. (NET-EGOV)

[recover-NNF-POSS.SG1] for work.hard-IP LV-PRES-SG1

'In order to recover, I have been working hard.'

If, however, the subject of the $-w$-clause is different from the main clause's subject, the agreement can always be indicated, and the subject of the non-finite clause bears the genitive or the unmarked genitive case. ${ }^{87}$ In examples (60) and (61) the subject of the $-w$ clause is different from the main clause's subject, and the agreement is marked on the predicate of the $-w$-clause. The subject in (60) is genitive-marked, while in (61) it is in the "unmarked" case. As the numbers show it, the genitive-marked subject is more preferred than the variant with the unmarked genitive subject.

[Суық-тың түс-у-і]-мен бірге маусым-дық

[cold-GEN fall-NNF-POSS.3]-INSTR together season-ADJ

ауру-лар да пайда бол-адьл. 20/15

illness-PL too (come.into.existence)-PRES.3

'Together with the setting in of the cold (weather), seasonal illnesses appear as well.'

(61) ? [Суық түс-у-і]-мен бірге маусым-дық

[cold fall-NNF-POSS.3]-INSTR together season-ADJ

ауру-лар да пайда бол-адыл. 20/9 (2 QM; 1 NA)

illness-PL too (come.into.existence)-PRES. 3

'Together with the setting in of the cold (weather), seasonal illnesses appear as well.'

In non-argument different subject $-w$-clauses the agreement could be left unmarked, and in this case the subject bears unmarked genitive case. This is illustrated in (62). This strategy (i.e. no agreement, unmarked genitive subject) is ungrammatical in case of argument -w-

\footnotetext{
${ }^{87}$ See sentences (8a)-(10c) in Questionnaire 2.
} 
clauses. Compare these examples with the above-mentioned argument clauses, notice that practically no native speaker accepted (different subject) argument $-w$-clauses without the agreement marking. Hence this is a crucial difference between argument and non-argument -w-clauses.

(62) \% [Суық түс-у]-мен бірге маусым-дық

[cold fall-NNF]-INSTR together season-ADJ

ауру-лар да пайда бол-адьл. 20/12 (2 QM)

illness-PL too (come.into.existence)-PRES.3

'Together with the setting in of the cold (weather), seasonal illnesses appear as well.'

It is noteworthy that $-w$-clauses that are complements of the modal non-verbal predicates such as kerek 'necessary' ${ }^{88}$, qažet 'necessary' or -DAT tiyis 'essential' pattern similarly to non-argument - $w$-clauses. First of all, the agreement can be absent, and the subject can be in the unmarked genitive case in these non-finites - a pattern that is not allowed in the argument $-w$-clauses. This is illustrated in (63), where these is no agreement marking on the $-w$-head, and the subject (Aral tejizi 'Aral sea') is in the unmarked genitive case. Note that it is possible to indicate the agreement on the - $w$-head, and mark the subject with the genitive (as in (64)).

(63) [Арал тензіз-і осы аттас құала-дан шамамен

[Aral sea-CM that namesake city-ABL about

он шақтты шақырырым жер-де бол-у] керек еді. (M/N, AA)

ten close kilometre place-LOC COP-NNF] necessary COP.PAST.3

'The Aral sea was supposed to be about ten kilometres away from its namesake city.'

(64) [Арал теңізі-і-нің осы аттас құала-дан шамамен он

[Aral sea-CM-GEN that namesake city-ABL about ten

шақты шақырым жер-де бол-у-ыл] керек еді. (PC., based on M/N, AA)

close kilometre place-LOC COP-NNF-POSS.3] necessary COP.PAST.3

'The Aral sea was supposed to be about ten kilometres away from its namesake city.'

\footnotetext{
${ }^{88}$ In contrast to Turkish, there is no verb *kerek- in Kazakh - for there is gerek- in Turkish -. That is, Kazakh kerek cannot take verbal suffixes.
} 
Abish (2014: 132) notes that if the $-w$ clause is the complement of kerek, qažet or -DAT tiyis, and if the $-w$ clause has a subject, the subject can either be "unmarked" or genitive-marked, and the different case-assignment does not affect the meaning of the sentence.

\subsubsection{2 -(I)s and -MAq-headed (non-argument) clauses}

$-(I) s$-headed non-finite clauses can only be the complements of the instrumental semantic case -Men. The agreement marking is obligatory on the non-finite head (Qazïbaev 1971: 34-35; QG: 702, 708-709; Tanç 2002: 192-193). Note that though the subject of these non-finite clauses can be in genitive, it is preferred to be used in the unmarked genitive case. ${ }^{89}$ This is shown in examples (65) and (66). In (65) the subject is in the unmarked genitive case, but in (66) it is in the genitive, with apparently no change in meaning.

[Өз құрылым-ыңыз

[own organisation-POSS.FORML ready COP-NNF-POSS.3]-INSTR Government-GEN ұсын-ван тұжырым-дар-ына жауап бер-у-іңіз-ге бол-ады. (NET-WP) render-NF decision-PL-POSS.3.DAT answer give-NNF-POSS.FORML-DAT LV-PRES.3

'As soon as your own organisation is ready, it will be possible for you to give a response to the decisions made by the Government.'
[Өз құрылымм-ыцыьз-дың
дайын бол-ьсс-ы] ]-мен

[own organisation-POSS.FORML-GEN ready COP-NNF-POSS.3]-INSTR

Үкімет-тің т ұсын-ван тұжырым-дар-ын-а

Government-GEN render-NF decision-PL-POSS.3.DAT

жауап бер-у-іңіз-ге бол-ады. (PC., based on NET-WP)

answer give-NNF-POSS.FORML-DAT LV-PRES.3

'As soon as your own organisation is ready, it will be possible for you to give a response to the decisions made by the Government.'

\footnotetext{
${ }^{89}$ If the genitive marking is not possible, it is due to the type of the noun phrase (for example indefinite noun phrases cannot be marked with the genitive).
} 
Of course, if the subject is the same as the superordinate clause's subject, it is dropped, but note that the agreement needs to be marked in this case too. This is shown in (67): note the agreement marking on the $-(I) s$ head.

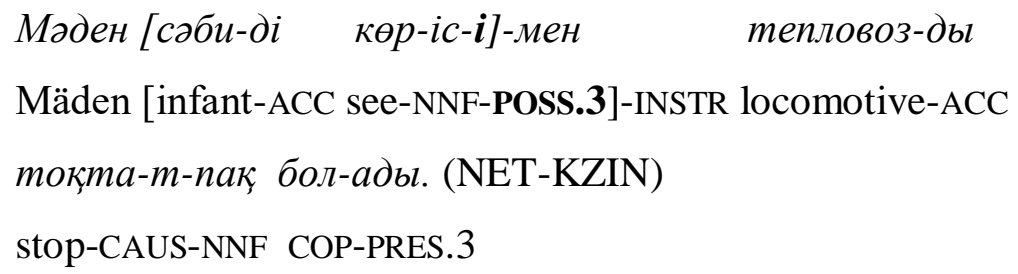

'The moment Mäden saw the infant, he wanted to stop the locomotive.'

The usage of $-M A q$-headed non-finite clauses is marginal. ${ }^{90}$ (Also note that the non-finite - $M A q$-head can be replaced by -w.) - $M A q$-headed clauses can be either the complements of modal non-verbal predicates (for example kerek 'necessary') or the postpositions üsin 'for' and tügil 'not even', or the (semantic) dative case expressing the aim of the superordinate predicate. In (68) the -MAq-clause is the complement of kerek 'necessary', but note that this is a very infrequent usage, because kerek most often has $-w$ as its complement.

[Үйрен-бек] керек (Kenesbaev 1962: 341)

[study-NNF] necessary

'it is necessary to study'

The $-M A q$ clauses are also very rarely used as complements of the postpositions $\ddot{u}$ šin and tügil, because $\ddot{u} s ̌ i n$ and tügil is generally used with -w-headed non-finite clauses. A rarely encountered example for a -MAq-clause being the complement of the postposition tügil can be found in (69).

\footnotetext{
${ }^{90}$ Abish (2014: 152) remarks that $-M A q$-headed non-finite clauses (or as she calls them: verbal nouns in $\left.\left\{-\mathrm{M}^{3} \mathrm{~A}^{2} \mathrm{~K}^{2}\right\}\right)$ are "restricted to older literary texts and petrified expressions". It is indeed true that the Kazakh grammars mostly quote their $-M A q$-clause examples from old works (such as Abay's poems, etc.). Abish (2014: 152 ) explains the relatively common use of $-M A q$-clauses in the $19^{\text {th }}$ centaury Kazakh literature with the influence of the Chagatay literary tradition.
} 
[Сені еркелет-пек] түгіл, өз бас-ын

[you.ACC care-NNF] not.even own head-POSS.3.ACC

көтер-е ал-ма-йдьл. (Ysqaqov 1967/II: 203)

raise-A LV-NEG-PRES.3

'(S)he cannot even recover (from an illness), how could (s)he care about you.'

\subsubsection{3 - $\dot{G} A n$ and $-y / A t I n$-headed complement clauses of semantic cases and postpositions}

A list of the semantic cases and postpositions that can have a non-finite complement clause was given in Chapter 1 .

If the subject of these non-finite clauses is the same as the subject in the superordinate clause, it is not necessary to indicate the agreement on the non-finite clause (and its subject cannot be overt). But similarly to non-argument $-w$-clauses, the agreement can be marked on the predicate of the $-\dot{G} A n$ or $-y / A t I n$-headed non-finite clause, even if it has the same subject as the superordinate clause. This is demonstrated in (70): the subjects of the superordinate and the subordinate clause are the same (112 adam '112 people'), and the agreement can still be indicated on the predicate of the non-finite clause (shown in bold).

112 адам [құжатсыз ҚР-да тұр-ыл жат-қ̧ан-ы]

112 person [without.document QR-LOC stand-IP LV.CONT-NF-POSS.3] because.of

әкімшілік жауапкершілік-ке тарт-ыл-дыл. 20/19

administration charge-DAT pull-PASS-PAST.3

'112 people were pressed legal charges against, because they were staying in the

Republic of Kazakhstan without any documents.'

If the subjects of the $-\dot{G} A n$ or $-y / A t I n$-headed non-finite and the superordinate clause are different, there can be three patterns (indicated with $\alpha, \beta$ and $\gamma$ in the above table).

Firstly, certain postpositions do not select for non-finite clauses with agreement marked on them. (Marked with $\alpha$ in the above table.) Such postpositions are, for instance, -(ABL) soy 'after', ${ }^{91}$ sayï 'every (time)' (there are possibly more of these, e.g. (-ABL) burïn

\footnotetext{
${ }^{91}$ The postposition $s o \eta$ 'after' assigns ablative to its complement if it is a "genuine" noun phrase; however, if its complement is a non-finite clause, it can be left unmarked.
} 
'before'). ${ }^{92}$ These non-finite clauses' subjects bear the nominative case. In the illustrative sentence-pair in (71) and (72) the - $\dot{G} A n$-headed non-finite clause is the complement of the postposition-(ABL) soy. The marking of the agreement is responsible for the unacceptability of (72), while the version without the agreement (in (71)) is grammatical.

[Оқ̆ас кел-ген] соң клуб іс-і жандан-дыл. 20/14 (2 QM; 1 NA)

[Oqas come-NF] after club business-CM liven.up-PAST.3

'After Okas arrived, the business livened up.'
*[Оқ̧ас-тың кел-ген-і]
соң клууб іс- $i$
жандан-ды. 20/0

[Oqas-GEN come-NF-POSS.3] after club business-CM liven.up-PAST.3

Intended: 'After Okas arrived, the business livened up.'

Secondly, certain semantic cases and postpositions "prefer" to have complement clauses with agreement marking. (Marked with $\beta$ in the above table.) These include the instrumental semantic case $(-M e n)^{93}$ and the postpositions twrali 'about' and üšin 'for; in order to' (possibly there are more of these, e.g. si aqti 'like'). ${ }^{94}$ The subject of the non-finite clause can bear the genitive or unmarked genitive case-marking. In the relevant sentences in the questionnaire the agreement-marked sentence variants were accepted by (sometimes much) more native speakers than the agreement-less non-finite clauses. Based on the data of the questionnaire, in all the other complement clauses (see sections VI.1, VI.2, VI.4, VI.5, VI.6, $V I .7$ in Questionnaire 2) the agreement-less variant is more preferred. In (73) the $-\dot{G} A n$-clause is the complement of the postposition twrali 'about', and the agreement is indicated on the non-finite predicate. The only difference between (73) and (74) is that in the latter the agreement is missing, rendering the sentence ungrammatical.

\footnotetext{
${ }^{92}$ See sentences (29a)-(29f) and (31a)-(31d) in Questionnaire 2.

${ }^{93}$ This property of the instrumental differentiates it from other semantic cases. Note, however, that in many respects the instrumental case is treated differently from the other case-markers: first of all, the vowel of the suffix does not harmonize, which makes the morpheme -Men an "oddity" among the other case suffixes. Also the so-called "pronominal n" is not used if -Men follows the $3^{\text {rd }}$ person singular/plural possessive suffix $(-(s) I)$. Note that the "pronominal n" shows up before all the case suffixes (dative, locative, ablative), as well as before the $-D A y$ and $-\check{s} A$ suffixes, i.e. all the case suffixes that can have a non-finite complement clause.

The fact that the instrumental patterns together with the postpositions and not with the case-suffixes is not a coincidence: it is well known that the suffix -Men has developed from a postposition. This also shows that (semantic) cases and postpositions are not all that different from each other.

${ }^{94}$ See sentences (26a)-(26b), (32a)-(33c) and (34a)-(35c) in the questionnaire.
} 
Pųtịn-GEN press secretary-POSS.3 [president-GEN

неке-ге тұр-ган-ыл] туралы хабар-ды жоққа шызар-ды. 20/19

marriage-DAT stand-NF-POSS.3] about news-ACC (refute)-PAST.3

'Putin's spokesman refuted the news about the president having gotten married.'

\section{(74) */?? Путин-нің, баспасөз хатшы-сы [ [президент}

Pųtịn-GEN press secretary-POSS.3 [president

неке-ге тұр-ван] тураль хабар-ды жоққа шызар-дыл. 20/4 (3 QM)

marriage-DAT stand-NF] about news-ACC (refute)-PAST.3

Intended: 'Putin's spokesman refuted the news about the president having gotten married.'

It is not all that clear from the data whether the agreement-less complement clause is even possible with the instrumental or with the afore-mentioned postpositions. In the questionnaire in some cases they are accepted by more than half of the speakers, still it is not a decisive number. ${ }^{95}$ There might be a (syntactic) dialectal difference here: some speakers accept the agreement-less variants too, but others do not. We have to leave this question open for now. (Hence the "question mark" in table (56) at the group 2ß.b.)

The semantic cases and postpositions that belong to the third group (marked with $\gamma$ in the table) allow both agreement-marked and agreement-less complement clauses. Most of the semantic cases (locative, dative, ablative, $-\check{s} A,-D A y)$ and a lot of postpositions belong here. As mentioned before, the variant in which the agreement is not indicated is more preferred than the one with the agreement (or at least, definitely not less-preferred). ${ }^{96}$ If there is no agreement, the subject is in the nominative case. This is shown in example (75), where the $-\dot{G} A n$-clause is the complement of the locative semantic case. Notice that there is no agreement, and the subject is nominative.

\footnotetext{
${ }^{95}$ For example, in the following sentence, in which the complement clause of -Men has no agreement marking.

(i) $? / \%$ [Әке-м негіз-гі тамыр-ы ақтөбе-лік бол-ган]-мен,

[father-POSS.SG1 basis-ADJ origin-POSS.3 Aqtöbe-ADJ LV-NF]-INST

туван жері Қарақалпақстан. 20/11 (1 QM)

be.born-NF place-POSS.3 Qaraqalpaqstan

'Although my father is essentially from Aktöbe, the place where he was born is Karakalpakstan.'

${ }^{96}$ See sentences (23a)-(24b), (25a)-(25d), (27a)-(27c), (29b), (29d), (30a)-(30b) in Questionnaire 2.
} 
'When I hit the drum, close the forty doors.'

The non-finite clause in (75) is acceptable with the agreement indicated in the non-finite clause, as shown in (76) and (77). In (76) the subject is in the unmarked genitive case, in (77) it is in the genitive. The latter seems to be less acceptable than the former. However, note that in other kinds of clauses (e.g. in the complement clauses of $-D A y$ ) the genitive-marked subject is perfectly grammatical. ${ }^{97}$

[Мен дан̧выра сок̧-қ̧ан-ыlм]-да,

I kind.of.drum hit-NF-POSS.1]-LOC

қ̧ырықық есік-ті бекіт-іп таста-ц̧дар. 20/15 (1 QM)

[forty door-ACC close-IP LV.C-IMP.PL2

'When I hit the drum, close the forty doors.'

(77) ??/? [Менің даңъвыра соқ̧-қ̧ан-ымм]-да,

[I.GEN kind.of.drum hit-NF-POSS.1]-LOC

қырырық есік-ті бекіт-іп таста-цудар. 20/8 (1 QM)

forty door-ACC close-IP LV.C-IMP.PL2

'When I hit the drum, close the forty doors.'

To sum up this section, three types of semantic cases/postpositions were distinguished: one that does not allow an agreement-marked complement clause $(\alpha)$, one that selects only for agreement-marked complement clauses $(\beta)$, and the one that allows both agreement-less and agreement-marked complements $(\gamma)$.

It is noteworthy that the instrumental and (at least some of the) postpositions belonging to the $\beta$-group (such as $\ddot{u}$ šin 'for, in order to' and si'aqtï 'like') could assign the genitive to their pronominal complement. (The semantic cases/postpositions belonging to the other groups do not have this property.) In (78) the complement of the instrumental bears

\footnotetext{
${ }^{97}$ As in the following sentence:

(i) [Алла елиі-сі-нің істе-ген-ін]-дей істе. 20/15 (3 QM; 1 NA)

[Allah delegate-CM-GEN do-NF-POSS.3]-DAy do.IMP.SG2

'Act as Allah's delegate does.'
} 
the genitive, ${ }^{98}$ similarly to (79) where the complement of the postposition $\ddot{u}$ šin bears the genitive. $^{99}$

оныци-мен

(s)he.GEN-INSTR

'with it (him/her), 100

менің ушін

I.GEN for

'for me'

My point is that it is not random that the complement clauses of these semantic cases/postpositions (of the $\beta$-group) pattern differently from the other semantic cases/postpositions, because those that belong to the $\beta$-group behave differently in other respects, too.

\subsubsection{4 - $(A) r$-headed complement clauses of semantic cases and postpositions}

It seems to be the case that $-(A) r$ (or $-M A s^{101}$ )-headed non-argument clauses cannot bear agreement, regardless of the semantic case or postposition. The subject of these clauses, if overt, is in the nominative case. An illustrative example in (80) demonstrates that the agreement is not acceptable on $-(A) r$-clauses. Sentence (80) can be corrected if we take away the agreement marked on the non-finite clause (as in (81)).

\footnotetext{
${ }^{98}$ It has to be mentioned that the "descriptively correct" version of example (78) is onïmen 〈онымен〉. (That is, this form is taught in teaching grammars.) Similarly to the singular third person form, the "descriptively correct" forms of the singular first and second persons are the following: тепітеn <менімен> 'with me', senimen <сенімен> 'with you (SG)'. I consider these as the shortened versions of the genitive-marked variant (as in (78)).

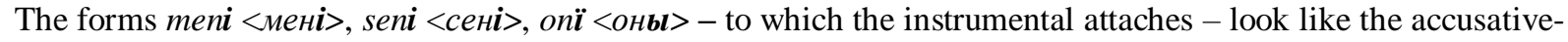
marked pronouns (тепі <мені> 'me', sеni <сені> 'you.ACC (SG)', опї <оны> 'him/her/it'), but it is highly unlikely that the instrumental would "trigger" accusative case-marking. This hypothesis is also supported by the data of other Turkic languages - such as, Turkish - in which the instrumental case (and, by the way, also the postposition için 'for; in order to') attaches to the genitive-marked form of a group of pronouns.

${ }_{99}$ The variant with nominative complement (men üšin) is used more often, but the above given genitive-marked form can be encountered too.

${ }^{100}$ It has to be noted that this form is mostly, although not exclusively, means 'with it' (e.g. in contexts such as: 'I agree with it/this/that').

${ }^{101}-$ MAs is the negative allomorph of $-(A) r$.
} 
[this event COP-NEG.NF-POSS.3]ABL before G.Karimova father-POSS.3-INSTR хабарлас-ып, Израиль-ге емдел-у-ге жібер-у-ін сұра-птыл. 20/5 communicate-CV İsrael-DAT recover-NNF-DAT send-NNF-POSS.3.ACC ask-EVID.3 Intended: 'Before this event, G. Karimova was in touch with her father and requested to be sent to Israel to recover.'

(81) [Осы оқива бол-мас]-тан бұрын Г.Каримова әке-сі-мен [this event COP-NEG.NF]-ABL before G.Karimova father-POSS.3-INSTR хабарлас-ыл, Израиль-ге емдел-у-ге жібер-у-ін сұра-пты. (NET-BAQ) communicate-CV İsrael-DAT recover-NNF-DAT send-NNF-POSS.3.ACC ask-EVID.3 'Before this event, G. Karimova was in touch with her father and requested to be sent to Israel to recover.'

\subsubsection{Notes on "adverbial clauses"}

In many works written about Kazakh or Turkic converb clauses the authors mention one more adverbial clause type, which is "participles followed by a word that expresses time". Their list of adverbial clause types can be seen below (cf. for example Tanç 2002):

1. converbs

2. "participles" 102 followed by a case suffix

3. "participles" followed by a postposition

\section{4. "participles" followed by a word that expresses time}

5. "verbal nouns" 103 followed by a postposition

I do not follow this approach, because my aim is not to write a teaching or descriptive grammar, but a theoretical work. From a theoretical point of view it is not justified to treat $-\dot{G} A n,-y / A t I n$ or $-(A) r$-headed clauses that modify a noun phrase which has an adverbial position in the main clause (the boldfaced group in Tanç's classification) as a separate group. They are in fact syntactically the same as the above discussed (non-subject) relative clauses.

\footnotetext{
102 The "participles" ("sıfat-fiil ekleri") are - $\dot{G} A n,-y / A t I n$ and -(A)r.

103 The "verbal nouns" ("isim-fiil ekleri") are $-w,-M A q$ and $-(I) s$.
} 
In these "adverbial clauses", if the subjects of the subordinate and the superordinate clause are the same, it is not necessary to mark the agreement in the non-finite clause (see example (82)), though this is possible.

[Алгаш-қ̧ы көр-ген] кез-де жалмауыз де-ді-м. (Tanç 2002: 187)

[first-ADJ see-NF] time-LOC witch ${ }^{104}$ say-PAST-SG. 1

'When I saw her for the first time, I said (she is a) witch.'

If the subjects of the RC and the superordinate clause are different, the agreement can be left unmarked, and in such case the subject is in the nominative case. In example (83) the non-finite's subject (sen 'you (SG)') is different from the main clause's subject (men 'I'). The agreement is not indicated and its subject is nominative.

[Сен кітапхана-ва бар-ван] кез-де мен дос-ьмм-мен

кездес-ті-м. (РС.)

[you library-DAT go-NF] time-LOC I friend-POSS.SG1-INSTR meet-PAST-SG1

'When you went to the library, I met my friend.'

However, the agreement is allowed to be indicated, and if it is, the marking is not on the predicate of the non-finite clause, but on the noun which is modified by the non-finite clause. The subject of the non-finite clause bears the genitive case. In (84) the agreement marking is found on the noun (kez 'time'), and the subject of the $-\dot{G} A n$-clause is in the genitive (seniy).

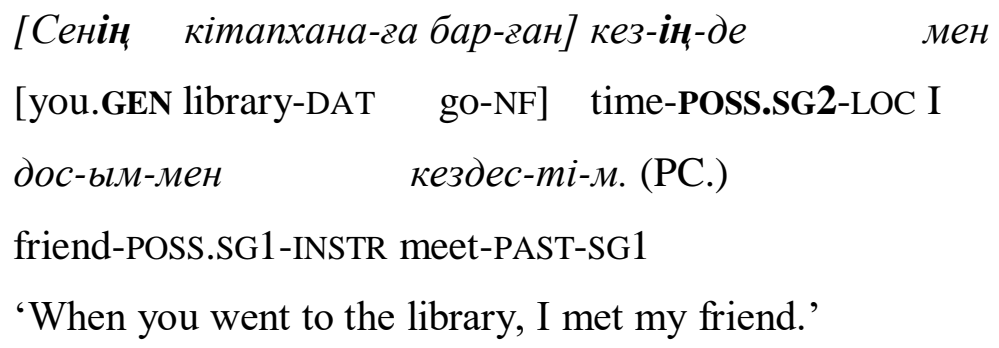

These patterns are the same as those we saw in relative clauses. Hence, from a syntactic point of view, these "kez-type of clauses" belong to relative clauses, and do not form a separate group among non-finite clauses.

${ }^{104}$ The word žalmawïz refers to a character in Kazakh fairy tales or folktales. 


\subsubsection{Interim summary}

First of all, there are crucial differences between the non-finite clauses depending on their position in the superordinate clause. Thus the properties of $-w,-\dot{G} A n,-y / A t \operatorname{In}$ and $-(A) r-$ clauses differ according to whether they are in argument or in non-argument position (and in case of $-\dot{G} A n,-y / A t I n$ and $-(A) r$-headed clauses there are additional differences between the relative clauses and complement clauses of semantic cases/postpositions). So the classification proposed in 4.1 holds not only for Turkish, but for Kazakh as well.

In same subject argument $-w$-clauses the agreement is not indicated, but in the same subject non-argument -w-clauses it can be indicated. Moreover, in different subject $\operatorname{argument}-w$-headed non-finites the agreement is obligatorily present, while in the different subject non-argument - w-clauses the agreement is mostly indicated, but in come cases the agreement could be absent too, and in such cases the subject is in the unmarked genitive case.

There are salient differences between argument and non-argument (i.e. relative clauses and complements of semantic cases/postpositions) $-\dot{G} A n,-y / A t I n$ and $-(A) r$-clauses as well: in same subject argument $-\dot{G} A n,-y /$ AtIn and $-(A) r$-clauses the agreement is either not present (see the first group) or it is obligatorily present (in the "reported speech" group), while in non-argument clauses it is preferred not to be indicated, although it can be present as well. Furthermore, in different subject argument clauses the agreement is obligatorily marked, in contrast to different subject non-argument $-\dot{G} A n,-y /$ AtIn and $-(A) r$-headed non-finites, in which the "most common" strategy is not to mark the agreement, and in such cases the subject is in the nominative case. (But there is some variation in this group regarding the acceptability of the agreement. For this, see the $\alpha, \beta$ and $\gamma$-groups in the table. Moreover, the relative clauses have some very peculiar patterns, with the agreement marked on the target of the RC.)

Secondly, there are differences between the $-w$ and the $-\dot{G} A n,-y / A t I n,-(A) r$-headed non-finite clauses, too. In argument position these clauses pattern almost ${ }^{105}$ the same way syntactically (according to the criterion of the agreement-marking - but note that this does not mean that they would be identical). However, in non-argument position there are important differences between $-w$ and $-\dot{G} A n(-y /$ AtIn, $-(A) r)$-clauses. In non-argument $-w$-clauses the agreement marking is always possible, in contrast to $-\dot{G} A n,-y / A t \operatorname{In}$ and $-(A) r$-headed clauses.

\footnotetext{
${ }^{105}$ The only difference is that in same subject - $w$-clauses the agreement cannot be marked, while it has to be marked in same subject "reported speech" - $\dot{G} A n(-y / A t I n,-(A) r)$-headed clauses.
} 
(Remember that in the $\alpha$-group the agreement marking is not grammatical, and even in the $\gamma$ group the default strategy is not to indicate it.)

It is clear from the above outlined dataset that $-w,-(I) s,-M A q,-\dot{G} A n,-y / A t I n$ and $-(A) r-$ headed clauses do not form a homogenous group in terms of their syntactic structure. Their syntactic properties differ with respect to their syntactic position in the superordinate clause (that is, it matters whether they are in argument or in non-argument position). Moreover, these clauses seem to have certain internal properties, too, that make them different from each other. (The main difference seems to be between the $-w$ and the $-\dot{G} A n(-y /$ AtIn, $-(A) r)$-headed clauses.) The next section attempts to give a syntactic analysis of these non-finite clauses that reveals what the difference is between these clauses.

\subsection{The syntactic analysis}

It seems to be obvious that there are two widely used different kinds of non-finite clauses in Kazakh: the $-w$-clauses on one hand and the $-\dot{G} A n(-y /$ AtIn and $-(A) r)$-headed clauses on the other. Although there are no linguistic works written about the difference between these Kazakh clauses, there are works aiming to determine the difference between the Turkish - $m A$ (the rough equivalent of Kazakh $-w$ ) and $-D X k /-(y) A c A k$-headed (similar to Kazakh $-\dot{G} A n$, $-y /$ AtIn and $-(A) r)$ clauses.

\subsubsection{Kornfilt's (2001a, 2003, 2006, 2007) approach}

Kornfilt's (2001a, 2003, 2006, 2007) analysis is mostly based on Modern Turkish data. The main issue she deals with is well-long-known fact that the subjects of $-D X k$ and $-(y) A c A k$ clauses are not always genitive-marked (Lewis: 1975, Haig 1998 etc.), in contrast to - $m A$ clauses, in which the subjects always bear the genitive. In the Turkish example in (85) the non-finite $-m A$-headed clause's subject is in the genitive. Note that the non-finite clause is the complement of the postposition sonra 'after', which assigns ablative to the clause. 
[İnternet kullanım-ı-nın yaygınlaş-ma-sin]-dan sonra

[Internet usage-CM-GEN spread-NNF-POSS.SG3]-ABL after

yaşam tarzl-mız çok değiş-ti.

life style-POSS.PL1 very change-PAST.SG3

'After the use of the Internet spread, our life style has changed a lot.'

The subjects of -DXk-clauses are genitive-marked and the agreement is marked on their predicates if the $-D X k$ clause is in argument position or if it serves as a relative clause. In contrast, the subjects of the $-D X k$-headed clauses which are complements of semantic cases or postpositions are not genitive-marked. ${ }^{106}$ This can be seen in the following Turkish example, where the subject of the -DXk-clause is in the default (which is in Turkish the unmarked) case.

[Can okul-a git-tiğ-in]-de ben ev-de-y-dl-m.

[Can school-DAT go-NF-POSS.SG3]-LOC I house-LOC-COP-PAST-SG1

'When Can went to school, I was at home.'

This last pattern is the same as in the 'regular' converb (or Adverbial - Kornfilt's (2001a) term) clauses (i.e. those headed by $-(y) X n c A,-(y) A l I$ etc.), where the subject of the converb clause is always in the default case. As can be seen in example (87), the subject (Can) of the converb clause is in the default case.

[Can kız arkadaş-ın-dan ayrıl-alı] beş ay ol-du.

[Can girl friend-POSS.SG3-ABL separate-CV] five month become-PAST.SG3

'It's been five month, since Can separated from his girlfriend.'

To sum up, $-D X k$ and $-m A$-clauses are somehow different, which shows up most prominently in complement clauses of semantic cases or postpositions. Kornfilt's (2001a, 2003, 2006, 2007) aim is to explain this difference, mostly based on Modern Turkish data, but applying her explanation to the Turkic languages as well (in Kornfilt 2001a). This approach is

\footnotetext{
${ }^{106}$ The exceptions to these generalization are the clauses with "comparative semantics" (Kornfilt 2001: 77-78). An example with the postposition $g i b i$ 'like' is offered in (i):

(i) Ben Ayşe'-yi [sen-in sev-diğ-in] gibi sev-e-me-di-m.

I Ayše-ACC [you-GEN love-NF-POSS.SG2] like love-ABILIT-NEG-PAST-SG1

'I couldn't love Ayse as you loved (her).'
} 
justified, because this difference turns up in other Turkic languages, too. As shown in the previous section, Kazakh $-w$ clauses are different from $-\dot{G} A n$-type of clauses.

First of all, Kornfilt (2001a: 70, 2003: 140-148, 2006: 150-155, 2007: 315-328) claims that the $-m A$ and the $-D X k$ heads embed verbal functional categories (that can be Negation, Voice, Modality Phrase etc.), and this verbal core is "dominated by nominal functional layers".

In Kornfilt's view, the subject of $-m A$-headed clauses and $-D X k$-headed argument clauses would move to the Specifier of a nominal functional category, and get the genitive case there. In Konfilt's view Agreement - nominal or verbal - is an independent syntactic projection in Turkish, and it assigns "genuine subject case" to the subject of its clause. In on of her more recent papers (Kornfilt 2007) she propses that agreement morphemes realize a Finite head. Although this is a somewhat different approach from that of the previous papers (2001a, 2003, 2006), her main claim remains unchanged, that is, argeement morphemes realize an independent syntactic head. ${ }^{107}$ Thus genitive subject case in -DXk and - $m A$-clauses is licenced by the nominal $\operatorname{Agr}^{\circ}$ head. In contrast to these, the subjects of 'regular' converb clauses (those headed by $-(y) X n c A$ or $-(y) A l I$ etc.) get default case, as shown in (87). ${ }^{108}$

But where does the difference between $-m A$ and $-D X k$ come from? And why is it that in adverbial -DXk-clauses the subject is not genitive-marked? According to Kornfilt's approach, Turkish $-m A$ head is "strongly nominal" (Kornfilt 2001a: 70-75), that is, it only consists of fully nominal layers (Kornfilt 2003: 148). In contrast, -DXk is "weakly nominal" (Kornfilt 2001: 70-75), meaning it has verbal layers as well, these would be the

\footnotetext{
${ }^{107}$ In Kornfilt's view the 'genuine' (i.e. not default) cases are licensed by the Agreement head in MT. This Agr head can be verbal or nominal; if it is verbal, the assigned case is the nominative, if nominal, the genitive. If there is no Agr head, but there is a bare subject (e.g. in the converb clauses), the subject is default case-marked. Kornfilt's (2003: 132-137) evidence for this comes from fully verbal subordinated clauses, in which the subject can only be present if there is an $\mathrm{Agr}^{\circ}$ head (i.e. agreement marking). This is shown in the grammatical example in (i) and in the ungrammatical (ii). The $\mathrm{Arg}^{\circ}$ head is highlighted with bold letters. (The examples and glossings are from Kornfilt 2003: 134-135.)

(i) [Sen dün sabah ev-de yemek pişir-iyor-du-n] san-dl-m. [you yesterday morning home-LOC food cook-PROGR-PAST-SG2] belive-PAST-SG1

'I believed (that) you were cooking food at home yesterday morning.' *[Sen dün sabah ev-de yemek pişir-iyor-du] san-dl-m. [you yesterday morning home-LOC food cook-PROGR-PAST] belive-PAST-SG1

It will be pointed out that a similar approach cannot hold for Kazakh (cf. the subject marking in the $-\dot{G} A n$ clauses).

${ }^{108}$ The difference between argument clauses (i.e. $-D X k,-m A$ ) and these converb (or Adverbial - Kornfilt's term) clauses would arise from their heads having different features. The Argument clauses would be $[-\mathrm{V},+\mathrm{N}]$, the converb clauses $[+\mathrm{V},+\mathrm{N}]$. The $[+\mathrm{V}]$ feature „motivates rejection of $>$ regular $<$ case assigned under government, and instead requires a special type of case. In most instances, this is the default case" (Kornfilt 2001: 71-72).
} 
Tense features ${ }^{109}$ (Kornfilt 2003: 141, 2007: 320) and a CP layer attached to the nominal layer (Kornfilt 2003: 142-148, 2007: 330-331). Thus -DXk-clauses are 'nominalized' clauses, in which a nominalizer is attached to a verbal core, but then verbal categories (Tense features, $\mathrm{CP})$ are adjoined to this nominalizer.

The case of the subjects of $-D X k$ and $-m A$-clauses is determined by the characteristics of the nominal heads (i.e. "strongly nominal" or "weakly nominal"). Because $-m A$ is "strongly nominal" (Kornfilt 2001: 75) or with other words "homogeneously nominal" and thus "harmonizes with the feature values of the nominal Agr morphology" (Kornflit 2003: 154), its subjects are always in the genitive. The genitive case in - $m A$-clauses is "licensed categorially within its clause" and "does not need any further licensing". But since -DXk-clauses are "weakly nominal" (Kornfilt 2001: 75) or categorically hybrid (Kornfilt 2003: 142-148), the $\mathrm{Agr}^{\mathrm{O}}$ head needs further licensing to be able to assign genitive to its subject. ${ }^{110}$ This means that in this case the Agr head needs to bear a referential index in order to be able to assign genitive to the subject. The referential indexation can be attained if the $\operatorname{Agr}^{\circ}$ gets a 'primary' Theta-role from a superordinate predicate (i.e. that happens in argument clauses), or it can come from a nominal head (in relative clauses) or from a comparative operator (in comparative clauses) (Kornfilt 2003: 164-172). Thus if -DXk-clauses are in adjunct position, their subject will be in the default case, their nominal Agr head is not able to assign a 'genuine' subject case to the subject, because of the "hybrid" character of this type of clause.

We face difficulties applying Kornfilt's analysis to Kazakh. In Turkish the agreement is (almost) ${ }^{111}$ always marked on the predicate of the non-finite clause. And the main difference between the clause types appears to be the subject's case marking. However, in Kazakh the main difference between $-w$ and $-\dot{G} A n$-type of clauses is the agreement marking (present either on the predicate of the non-finite clause or on the noun phrase that the relative clause modifies).

Thus I am not going to follow Kornfilt's analysis, but it needs to be emphasised that it had a significant influence on my analysis.

\footnotetext{
${ }^{109}$ She refers to the distinction between $-D X k$ and $-(y) A c A k$, the former referring to perfective or simultaneous events, the latter to prospective events. (One might argue, however, that this distinction is only aspectual.)

${ }^{110}$ A similar but somewhat 'less theoretical' approach is found in Kornfilt 2001 (73), where Kornfilt claims that the genitive can only be assigned to the subjects of the non-finite clauses if the government of a superordinate predicate "unlocks the Case potential of the agreement morphology".

${ }^{111}$ Except for the $-m A k$ clauses in which the agreement cannot be indicated; and the above mentioned $-D X k c ̧ A$ and -DXktan sonra-headed adverbial clauses.
} 


\subsection{2 'Nominalized clauses' revisited}

In what follows I am going to argue that the difference in agreement marking (and in the subjects' case marking) between the $-w$ and the $-\dot{G} A n(-y / A t I n,-(A) r)$-clauses can be explained by their category (i.e. nominal or not nominal). I claim that one type of Kazakh clause $(-w)$ is nominal, while the others $(-\dot{G} A n,-y / \operatorname{AtIn},-(A) r)$ are not nominal at all. That is, the $-w$ head is a nominalizer, while the heads $-\dot{G} A n,-y / A t \operatorname{In}$ and $-(A) r$ are not nominalizers. In the what follows, I will attempt to support this claim.

In 4.4.3 evidence will be given that $-w$-clauses are indeed nominal. In 4.4 .4 the $-\dot{G} A n$ type of clauses will be discussed: it will be explained how it is possible that $-\dot{G} A n$-clauses can be found in nominal positions (e.g. in argument position), seemingly contradicting to my claim that $-\dot{G} A n,-y / A t \operatorname{In}$ and $-(A) r$ are not nominalizers.

\subsubsection{The nominalizer $-w$}

In 4.3 it was shown that the agreement can always be indicated on different subject $-w$-headed non-finite clauses. I claim that the reason for this is that $-w$ is in fact a nominalizer head, and the nominal agreement marker can always attach to nominal items.

In Chapter 2 it was shown that the $-w$-head can embed a number of verbal functional categories (up to the Continuous Phrase). As shown on the tree below, $\mathrm{v}_{\mathrm{Cont}} \mathrm{P}$ is the last verbal functional category that can precede the $-w$-head. (However, this does not mean that $\mathrm{v}_{\text {Cont }} \mathrm{P}$ would be obligatoryly overt.) Other lower verbal functional categories are naturally allowed too. As discussed in detail in 4.4.3.3, I analyze $-w$ as a Determiner head, which is resposible for nominalizing the verbal structure. Moreover, I claim that the Determiner $-w$, as all Detrminer heads in Kazakh, has a [+AGR] feature, what allows the agreement to be indicated in it. In contrast to Kornfilt's analysis for Turkish (2001a, 2003, 2006, 2007), I do not assume an independent AgrP in Kazakh. 
(88) The structure of $-w$-headed non-finite clauses

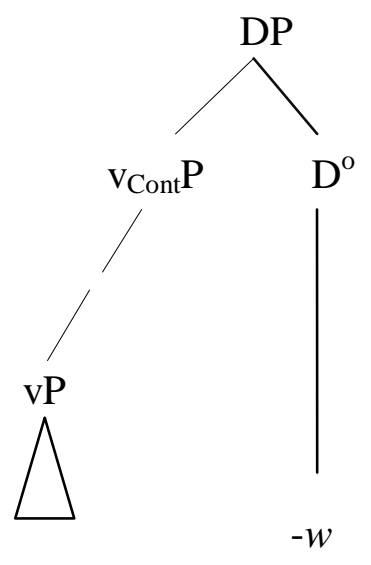

In what follows, I am going to argue that $-w$ is a nominalizer showing that $-w$-clauses behave like noun phrases (in 4.4.3.1 and 4.4.3.2). Moreover, I will claim that the fact that nominal agreement can always be indicated on (different subject) -w-clauses also supports this appraoch. (In contrast, to - $\dot{G} A n,-y / A t I n$ and $-(A) r$-headed clauses; cf. 4.4.4.) Towards the end of section 4.4.3, I will elaborate on the exact nature of -w-head: I will claim that it is not a little $\mathrm{n}$ head, but rather a Determiner.

\subsubsection{Nominal compounds}

In Kazakh nominal compounds, a compound marker appears on the second noun head. (The second noun has to be a noun head, it cannot be modified by adjectives, numerals etc.) This compound marker has the same realization as the singular/plural $3^{\text {rd }}$ person possessive suffix $-(s) I$. (Naturally, there is much more to say about the nominal compounds, but this much is sufficient for the purposes of the present study.) In the noun compounds in (89) and (90) the compound marker $-(s) I$ turns up on the second noun heads (i.e. on sömke 'bag' and žumïs 'work').

$$
\begin{aligned}
& \text { мектеп сөмке-сі } \\
& \text { school bag-CM } \\
& \text { 'schoolbag' }
\end{aligned}
$$


house work-CM

'housework'

In the surface structure the main difference between the compounds and the 'regular' possessive constructions is the lack of the genitive suffix on the 'possessor' (which is the first noun phrase). ${ }^{112}$ A possessive construction is found in (91), where the possessor (Aisha) is genitive-marked, in contrast to example (89), where the first noun is not in the genitive.

(91) Айша-ның сөмке-сі

Ayša-GEN bag-POSS.3

'Aisha's bag'

If an $-w$-headed clause and a noun head form a nominal compound, they exhibit exactly same pattern that we saw in (89)-(90) in "regular" nominal compounds: the compound marker appears on the second noun head. Consider the following examples in which the -wheaded non-finite clause forms a nominal compound with a noun head: with žumïstar 'works' in example (92) and with bagït 'respect, relation' in (93). The noun heads (žumïstar and bag̈̈̈) have to be marked with the compound marker (cf. the ungrammatical (94) and (95), in which there is no compound marker), indicating that, since $-w$-headed non-finite clauses syntactically behave as nouns, they are indeed nominalized clauses.

(92) [«Коста Конкордиа»кеме-сін көтер-у] жұмыс-тар-ы

[Costa Concordia ship-CM.ACC raise-NNF] work-PL-CM

аяқ̧тал-дыл. (NET-T24)

finish(intr)-PAST.3

'The works of lifting the ship Costa Concordia have come to an end.'

\footnotetext{
${ }^{112}$ For a detailed analysis on Turkish nominal compounds see Tat 2013. Although Tat's work is about Turkish, given the similarity between Turkish and Kazakh compounds, her approach is applicable for Kazakh as well.
} 
work-PL

'The efforts to increase the knowledge of civil servants...'

As shown in examples (94)-(95), the constructions in (92)-(93) are ungrammatical without the compound marker.

(94) *[«Коста Конкордиа»кеме-сін көтер-у] жұмыс-тар

[Costa Concordia ship-CM.ACC raise-NNF] work-PL

аяқ̧тал-дыл. (РC., based on NET-T24)

finish(intr)-PAST.3

Intended: 'The works of lifting the ship Costa Concordia have come to an end.'

(95) *[Қызметкер-лер-дің біліктіліг-ін

көтер-у] бавыт-та-вы

[civil.servant-PL-GEN knowledge-POSS.3.ACC raise-NNF] respect-LOC-ADJ

жұмыс-тар... (PC., based on NET-AQT)

work-PL

Intended: 'The efforts to increase the knowledge of civil servants...'

It is noteworthy that if $-\dot{G} A n,-y / A t \operatorname{In}$ or $-(A) r$-headed relative clauses modify noun phrases, the compound marker is not allowed to be indicated on the modified noun phrase. In (96) the -y/AtIn-headed clause modifies the noun phrase žumïs 'work', and no compound marker can be present. This would be ungrammatical with -w-clauses (cf. (94)-(95)).

(96) Маван [демальс кун-дер-і істе-йтін] жұмыс керек еді. (NET-SZH)

I.DAT [rest day-PL-CM do-NF] work necessary COP.PAST.3

'I would need a job that can be done on the weekends.'

$-\dot{G} A n,-y / A t I n$ and $-(A) r$-headed relative clauses are clearly situated in a different syntactic position than $-w$-clauses, which are in the same syntactic position as the first noun in "regular" nominal compounds. In contrast, $-\dot{G} A n,-y / A t \operatorname{In}$ and $-(A) r$-headed relative clauses are 
adjuncts inside the DP (Determiner Phrase). ${ }^{113}$ This is supported by the position of relative clauses inside determiner phrases: they precede numerals and adjectives. In (97) it is demonstrated that relative clauses precede numerals (see the position of eki 'two' in the example).

[Анадайжер-де ұста-п тұр-ван] екі інген-ді

[that place-LOC hold-IP LV.CONT-NF] two she.camel-ACC

қоя бер-іңдер деп бұйыр-ыnтыл. (KV, BP)

release.A LV-IMP.PL2 DISC.PART order-EVID.3

'He ordered the two she-camels being held at that place to be released.'

The order of the relative clause and the adjective(s) is also fixed: the RC preceeds the adjectives. This offers good evidence for relative clauses not being 'adjectival clauses' (a claim that is sometimes made in the traditional literature). The position of adjectives can be interchangeable, but the position of a relative clause and an adjective can never be inverted.

The claim that $-\dot{G} A n$-type of relatives are indeed inside the DP can be supported if we take a look at the position of the determiner (e.g. demonstrative pronoun) and the RC. The neutral ${ }^{114}$ position of the RC is after the demonstrative, as shown in (98). Thus RCs are indeed inside the DP.

\section{(98) [...] осы [мен ұста-n тұр-ван] ииша-ва кір-іп кет-е-сіңдер. (KV, ВР)}

this [I hold-IP LV.CONT-NF] bottle-DAT enter-IP LV-PRES-PL2

'You'll go into this bottle I'm holding.'

To sum up, -w-clauses behave like nouns, while - $\dot{G} A n$-clauses do not.

\footnotetext{
${ }^{113}$ Note that Kornfilt (2001: 78-79) also claims that the Turkish RCs are adjuncts.

${ }^{114}$ If the demonstrative pronoun is the focus of the clause, the RC and the demonstrative pronoun can be inverted. This is demonstrated in the following examples: in (i) the ordering reflects no emphasis on any element in the clause. In (ii) the demonstrative bul 'this' is the contrastive focus, the speaker wants to express that this dream is the one that the padishah had, and made him glad (but not his other dreams). Thus the neutral determiner - RC ordering can be inverted if the information structure of the clause requires it.

(i) Патма бұл [көр-ген] түс-іне сүйсін-іп, [...] $(\mathrm{KV}, \mathrm{BP})$ padishah this [see-NF] dream-POSS.3.DAT be.glad-CV ...

'The padishah being delighted with this dream of his that he had, ...'

(ii) Патиа [көр-ген] бұл түс-іне сүйсін-іn, [...] (PC., based on KV, BP) padishah [see-NF] this dream-POSS.3.DAT be.glad-CV ...

'The padishah being delighted with (only) this dream of his that he had, ...'
} 


\subsubsection{Suffixes attached to non-finite heads}

There are suffixes that can only attach to nouns (especially the morpheme $-s ̌ I$ will be relevant here). Other derivational suffixes (such as $-D A y$ and $-\check{s} A$ ) do not exclusively select for nouns, these can attach to nouns or adjectives as well. We will see that the morphemes that can only attach to nouns can be joined to the $-w$-head, but not to $-\dot{G} A n,-y / A t I n,-(A) r$. However, those morphemes that can adjoin other categories, not only nouns, can attach to $-\dot{G} A n,-y / A t I n,-(A) r$ as well.

\subsubsection{1 -DAy and $-\check{s} A$}

We shall begin with $-D A y$ and $-\check{s} A$. The most important feature of these morphemes is that while they can join nouns or noun phrases, they can also be attached to other units bearing a different categorical feature. (For the former see Kenesbaev 1962: 220-221, for the latter Kenesbaev 1962: 209.) In (99) we see an example for -DAy attaching to a noun.

(99) арыстан-дай

lion-like

'like a lion'

In example (100) -DAy is attached to the adjective qalï 'thick, dense'.

(100) қ̧альџң-дай өс-кен аваш-тар

thick-like grow-NF tree-PL

'densely growing trees'

Moreover, -DAy can also join a numeral (Kenesbaev 1962: 220-221), expressing 'approximately that much', as example (101) shows it.

(101) жиырма-дай адам (Kenesbaev 1962: 221)

twenty-like man

'about twenty men' 
The same is true for $-\check{s} A$ : it can attach to nouns and it derives adjectives. For instance, in (102) $-\check{s} A$ can be found attached to the noun $\ddot{o g i z}$ ' ox'.

(102) өгіз-ие (Kenesbaev 1962: 209)

ox-like

'like an ox'

But it can also adjoin an adjective, as in the following examples.

(103) ак̧-ша (Kenesbaev 1962: 208-209)

white-like

'whitish' (Note that another meaning of the word is 'money'.)

(104) Ұзын-ша (Kenesbaev 1962: 208-209)

long-like

'quite long, longish'

In (104) we can see that $-\check{S} A$ joins the quantifier $\check{s} o q$ 'a group of; a bunch of'.

(104) шок-ша

bunch-like

'quite many, a bunch of something'

Thus we can conclude that $-D A y$ and $-\check{s} A$ can select for units with various categorical features, and not exclusively for nouns. Since $-D A y$ and $-\check{S} A$ select not only for nouns, they can attach to $-\dot{G} A n,-y /$ AtIn and $-(A) r$ (which are not nominals, as I will argue). (105) and (106) exemplify this. In sentence (105) $-D A y$ follows the $-\dot{G} A n$-headed clause (i.e. $-D A y$ can take a $-\dot{G} A n$-headed complement clause). 
(105) [Өз-іңуіз куә бол-ван]-дай, бастаңувы туральы

[self-POSS.FORML witness COP-NF]-DAy bastanğï about

түсінік тым таяз-да. (M/N, BB)

knowledge fairly shallow-LOC

'As you (yourself) witnessed it, the knowledge about the bastanggy ${ }^{115}$ is pretty shallow.'

If a - $\dot{G} A n$-clause combines with $-\check{S} A(-\dot{G} A n \check{S} A)$ the non-finite clause - among other things can express 'until something has happened'. (-y/AtIn and $-(A) r$ are not combinable with $-\check{S} A$.) Note that $-\check{S} A$ can also select for $-w$-headed clauses - naturally, this is a possible scenario, because $-\check{S} A$ can attach to nouns as well. An example is given in (107).

(106) ББұл бала өс-іn, біз-ді асыра-ван]-ша, талай уақыт бар. (KV, HMV)

[this child grow-CV we-ACC support-NF]-šA a.lot.of time exist

'There is a lot of time (left) until this child grows up and supports us.'

(107) [Қанат-тың айт-y-blн]-ша, [...](NET-KZIN2)

[Qanat-GEN say-NNF-POSS.3]-̌̌s ...

'According to what Kanat said [...]'

\subsection{The noun-selecting suffix $-\check{s} I$}

Now, we will turn to the suffix -šI. Examples (108)-(110) show that -šI can select for nouns. (The morpheme $-\check{S} I$ is often referred to as the "formative of profession names", but this is not its only function.)

(108) жұмыс-шы

work-šI

'worker'

\footnotetext{
${ }^{115}$ Bastanghy is a Kazakh tradition: the girls of the neighbourhood get together to eat and talk in the house of the girl whose relatives left for a longer journey.
} 
language/tongue-šI

'correspondent'

\section{$x a m-u b l$}

letter/piece.of.writing-šI

'secretary'

In contrast to $-D A y$ and $-\check{S} A,-\check{S} I$ can only select for nouns. ${ }^{116}$ Moreover, $-\check{S} I$ can only select for $-w$ and $-M A q$-headed non-finite clauses, ${ }^{117}$ but not for $-\dot{G} A n,-y / \operatorname{AtIn}$ or $-(A) r$. This piece of evidence once again indicates that $-w($ and $-M A q)$ are categorically nouns, and we see no evidence for this in case of $-\dot{G} A n,-y / A t I n$ and $-(A) r$. Both -wšI (Ysqaqov 1967/I: 180) and $-M A q S \check{I}$ modify noun phrases, ${ }^{118,119}$ under the condition that the modified noun phrase is human (or to be more precise, an agent) (Kenesbaev 1962: 324-325). It is worth emphasising

${ }^{116}$ This $-\check{s} I$ has nothing to do with the morpheme $-s ̌ I$ that can attach to imperative predicates, as illustrated in (i). The stress patterns of the two suffixes support this claim: the morpheme $-\check{s} I$ that selects for nouns is stressable, in contrast to $-\check{s} I$ that joins imperatives (cf. QG 101).

(i) Omblp-blḩbls-übl.

sit-IMP.FORML-POL

'Sit down please.'

$117-w+\check{s} I$ can also be used to form deverbal nominals (as discussed in 4.2.2). Examples (i) and (ii) illustrate this.

(i) $\quad$ kқy-ubl

read.w-šI

(ii) жаз-y-ubl

write-w-šI

'writer'

${ }^{118}$ Note that I treat the non-finite and finite uses of the $-w+\check{S} I$ and $-M A q+\check{S} I$ heads completely separately. Finite $-M A q s ̌ I$ denotes events that are planned, intended to be carried out in the future (by an agent actor). This is illustrated in example (i).

(i) Aлматы-ва бар-мақ̧шы-мын.

Almaty-DAT go-INT.FUT-SG1

'I intend to go to Almaty.'

-wšI used with the past copula edi expesses habitual actions in the past (Abish 2014: 64). An example is offered in (ii). Note that I give the examples from Abish's book according to the standard Kazakh ortography.

(ii) Ахмет таңертең-дер-і бір алма же-уші еді. (Abish 2014: 64)

Ahmet morning-PL-TEMP one apple eat-CONT COP.PAST.3

'Ahmet used to eat an apple in the morning.'

If $-M A q \check{S} I$ and $-w s ̌ I$ are used to mark finite predicates the Type-1 agreement morphemes attach to them. (It is not possible to mark agreement on the non-finite $-w+\check{s} I$ and $-M A q+\check{s} I$ heads. Thus this is a clear difference between the finite and the non-finite usage.)

${ }^{119}$ Note that the non-finite head -MAq can modify noun phrases in a few cases (Abish 2014: 154), such as in (i). This very marginal usage is similar to English infinitive modifying noun phrases.

(i) aŭm-пақссөз (Abish 2014: 154) say-MAq word 'a word to say' 
that the modified noun is always the subject of the modifier $-w$ or $-M A q$-marked non-finite clause. Examples for -wšI are given in (111) and (112).

(111) [Жатақхана-да тұр-у]-шы студент-тер күн сайын

[dormitory-LOC live-NNF]-šI student-PL day every

ерте-мен гимнастика жаса-йды. (Kenesbaev 1962: 324)

early-INSTR gymnastics do-PRES.3

'The students who live in the dormitory do gymnastics every day early in the morning.'

(112) [музыка үйрен-у]-шы бала (Balaqaev-Isqaqov 1954: 326-327)

[music learn-NNF]-šI child

'the child who learns music'

An example with -MAqšI can be found in (113). The difference between -wšI and $-M A q s \check{I}$ clauses is that $-M A q$ expresses intention, while $-w$ does not (cf. (112) and (113)). Abish (2014: 151) notes that -MAqšI is mostly used in spoken registers. In written registers the construction -MAqšI bolgan (< bol- 'to become; copula' $+-\dot{G} A n)$ is more common. ${ }^{120}$

(113) [ертеңз кел-мек]-ші адам (based on Kenesbaev 1962: 324; PC.)

[tomorrow come-NNF]-šI man

'the man who intends to come tomorrow'

Thus we can conclude that $-w$-headed non-finite clauses have the same syntactic properties to noun phrases, while $-\dot{G} A n,-y / A t I n$ and $-(A) r$-clauses do not.

\footnotetext{
${ }^{120}$ It is also noteworthy that if the modified noun is omitted, the plural, the possessive and case endings can not attach to -MAqšI, only to bolġan (Abish 2014: 151).
} 


\subsection{A short note on semantic cases and postpositions}

As it was shown above, semantic cases (such as the dative, the locative, the ablative, the instrumental, $-\check{S} A$ and $-D A y)$ and postpositions can adjoin the $-\dot{G} A n,-y / A t I n,-(A) r$ and the $-w-$ headed non-finite clauses. These semantic cases do not select exclusively for noun phrases. (For this, see Kornfilt 2001: 73.), and the same is true for postpositions. Both Turkish and Kazakh offer evidence for this: in Turkish $-(y) X n c A$ is a converb-head, that is, it can only head adverbial clauses, thus $-(y) X n c A$-headed clauses can never be, for instance, in argument position. But interestingly, $-(y) X n c A$-clauses can be complements of the postposition -DAT kadar $^{1}$ 'to, until', ${ }^{121}$ which assigns dative case to the $-(y) X n c A$-headed clause. This is shown in example (114).

(114) [Göl-e su gel-ince]-ye kadar kurbağa-nın göz-ü patla-r.

[lake-DAT water come-CV]-DAT until frog-GEN eye-POSS.SG3 explode-AOR.SG3

lit. 'Until the water arrives to the lake, the eye of the frog will explode.' (proverb)

Kazakh $-\dot{G} A l I$-headed converb clauses can only be used in adverbial position, and never as noun phrases, yet $-\dot{G} A l I$-clauses can be complements of the postposition (-ABL) beri 'since, for'. The only difference between these constructions and regular noun phrases is that beri does not license ablative case to the $-\dot{G} A l I$-clause. An example is offered in (115).

[Тууелсіздік ал-валы] бері ел-іміз-де

[independence get-CV] since country-POSS.PL1-LOC

2300-ден астам мешіт сал-ын-ды. (NET-AST)

2300-ABL more mosque built-PASS-PAST.3

'Since we gained independence, more than 2300 mosques have been built in our country.'

Thus the fact that the $-\dot{G} A n$-type of clauses can be complements of semantic cases and postpositions is not an obstacle for analyzing them as non-nominals. (The accusative case indeed poses a problem, but that issue will be resolved shortly.)

\footnotetext{
${ }^{121}$ Note that there is an other $k a d a r^{2}$ that means 'to such a degree that...', but kadar $^{2}$ licences nominative case (or genitive to a certain group of pronouns).
} 


\subsubsection{3 $-w$ as a Determiner head}

In 4.4.3.1 and 4.4.3.2 it was shown that $-w$-clauses behave syntactically as noun phrases. Thus it is clear that $-w$ must be analyzed as some sort of nominalizer.

Alexiadou and her co-authors (2011) propose that the differences between nominalizations in different languages lie in the absence or presence of certain verbal and nominal functional categories. They take a closer look at Spanish, Romanian, English and German, and find that some nominalized constructions are "more verbal", while others are "more nominal". Certain nominalizations exhibit many properties that are characteristic to verbal structures, such as: subject with nominative case; occurrence of modal or auxiliary verbs; accusative case on subjects; projection of outer Aspect; Argument Structure realization (Alexiadou et al. 2011: 29). If a nominalized construction has all these properties (for instance, Spanish verbal infinitives are such), it is because it includes a full array of verbal functional projections. Spanish verbal infinitives consist of the following structure (Alexiadou et al. 2011: 36):

\section{[DP [TP [Aspect [VoiceP [vP [Root]]]]]]}

Other kinds of nominalizations have more nominal features: genitive/PP subjects; genitive/PP objects; gender features; availability of plural; possibility to combine with all types of determiners (Alexiadou et al. 2011: 29-32). Romanian infinitives and English nominal gerunds have more of these nominal features and less of the above-mentioned verbal ones. Alexiadou et al. (2001: 37) attribute the following structure to the Romanian infinitives and English nominal gerunds:

$$
[\mathrm{DP}[(\text { NumberP) }[\text { ClassP }[+/- \text { count }][\mathrm{nP}[\text { VoiceP }[\mathrm{vP}][\ldots]]]]]]
$$

In case of this latter type of nominalizations, the abundance of nominal functional categories is responsible for their "more" nominal character.

The question immediately arises: how can Kazakh - w-clauses be analyzed along these lines. It has been demonstrated in Chapter 2 that the $-w$-head can embed as many verbal categories as Inflection heads can, that is, the $-w$-head follows the $\mathrm{v}_{\text {Cont }} \mathrm{P}$ (see example (118)). 
Thus it is clear that -w-clauses are "more verbal", since they include quite many verbal functional categories.

(118) Ал арнайь мектеп-тер-де қ̧абілет-іне қ̧арай ұстаз-дар and especially school-PL-LOC talent-POSS.3.DAT according teacher-PL бавыт-бав-дар бер-іп отыр-y-bl muіс. (M/N-KMK) direction-PL give-IP LV.CONT-NNF-POSS.3 obliged 'And especially in schools the teachers have to be giving (him/her) guidance in accordance with his/her talents.'

However, - $w$-clauses seem to lack a wide array of nominal projections. From the nominal features that Alexiadou et al. (2011) mention in their study, plural marking on the nominalization is relevant for Kazakh as well: $-w$-clauses have no plural form, as illustrated by the ungrammatical examples (119) and (120). (Note that the sentences are correct without the plural marking.) This suggests that Number Phrase is not available in case of $-w$-clauses.

(119) *[Тамақ пісір-у-лер]-ді жжақсы көр-е-мін. (РС.)

[food cook-NNF-PL]-ACC (like)-PRES-SG1

Intended: 'I like cooking (several times).'

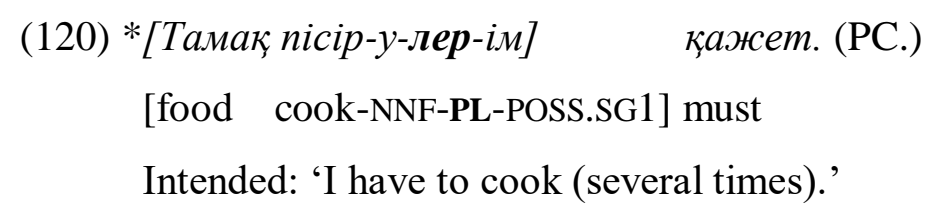

Moreover, determiners, such as the indefinite article bir 'a/an; one' and demonstrative pronouns, cannot modify $-w$-clauses. Sentences (121) and (122) illustrate that $-w$-clauses are not acceptable with the indefinite article; (123) and (124) show the ungrammaticality of -wclauses with the demonstrative bul 'this'.

(121) *[Бір пісір-y]-дi жақссы көр-е-мін. (РС.)

[a cook-NNF]-ACC (like)-PRES-SG1

Intended: 'I like to cook (once).' 
(122) *[Бip nicip-y-iм] қ̧ажет. ${ }^{122}$ (PC.)

[a cook-NNF-POSS.SG1] must

Intended: 'I have to cook (once).'

(123) *[Бұл nicip-y]-дi ж жақсы көр-е-мін. (РС.)

[this cook-NNF]-ACC (like)-PRES-SG1

Intended: ' I like this cooking.'

(124) *[Бұл пісір-y-ім] қ қажет. ${ }^{123}$ (РC.)

[this cook-NNF-POSS.SG1] must

Intended: ' $\sim$ I have to this cooking.'

These facts indicate that Kazakh $-w$-clauses cannot be modified neither by Number or Determiner Phrases. It is also noteworthy that predicates of Kazakh non-finite clauses can only be modified by adverbs, and not by adjectives. Although adverbials and adjectives mostly appear to be the same in Kazakh (i.e. tez 'quick; quickly'), there is a way to distinguishing between the two. Locative phrases, for instance asüyde 'in the kitchen' (< asüy 'kitchen' + - de LOC), can only modify verb phrases (cf. (125)).

\section{Шеше-м-нің асүй-ін-де тамақ̆пісір-ді-м.}

\section{mother-POSS.SG1-GEN kitchen-POSS.3-LOC food cook-PAST-SG1}

'I cooked in my mother's kitchen.'

Locative phrases can only modify noun phrases if they have been "turned into" attributive adjectives by the suffix $-\dot{g} I$ first, as in (126).

Шеше-м-нің

mother-POSS.SG1-GEN kitchen-POSS.3-LOC-ADJ food

'the food in my mother's kitchen'

\footnotetext{
122 Note that (121) and (122) do not include the object tamaq 'food'. If they did, the sentences would be grammatical, but bir 'one, a/an' would modify tamaq, i.e. their meaning would be 'cooking one (particular) meal'.

${ }^{123}$ Note that if (123) and (124) included the object tamaqti 'food-ACC', the sentences would be grammatical under the reading 'cooking this food', i.e. bul 'this' would modify tamaq.
} 
-w-clauses cannot be modified by $-\dot{g} I$-marked locative phrases, as shown in (127) and (128), but they can be modified by "regular" locative phrases, as in (129) and (130).

(127) *[Шеше-м-нің

acүŭ-iн-дe-zi

тамақ̧ пісір-y]-di

[mother-POSS.SG1-GEN kitchen-POSS.3-LOC-ADJ food cook-NNF]-ACC

жақссы көр-е-мін. (РС.)

(like)-PRES-SG1

Intended: 'I like to cook in my mother's kitchen.'

(128) *[Менің шеше-м-нің

асүй-ін-де-гі

тамақ пісір-y-iм]

[I.GEN mother-POSS.SG1-GEN kitchen-POSS.3-LOC-ADJ food cook-NNF-POSS.SG1] қ̧ажет. (РC.)

must

Intended: 'I have to cook in my mother's kitchen.'

(129)

[Шеше-м-нің асүй-ін-де тамақпісір-y]-ді

[mother-POSS.SG1-GEN kitchen-POSS.3-LOC food cook-NNF]-ACC

жақсы көр-е-мін. (РС.)

(like)-PRES-SG1

'I like to cook in my mother's kitchen.'

(130) [Менің шеше-м-нің

асүй-ін-де

тамақ nicip-y-iм]

[I.GEN mother-POSS.SG1-GEN kitchen-POSS.3-LOC food cook-NNF-POSS.SG1] қ̧ажет. (РС.)

must

'I have to cook in my mother's kitchen.'

These data suggest that $-w$-clauses do not have a rich nominal layer, what, I propose, is because $-w$ is not a little $\mathrm{n}$ head, but rather a $\mathrm{D}$ (eterminer) head. Analyzing $-w$ as $\mathrm{D}^{\mathrm{o}}$ explains the lack of Adjective Phrase, Number Phrase and (other) Determiner Phrases: Adjective and Number Phrases are below $\mathrm{D}^{\circ}$, that is, if $-w$ is indeed $\mathrm{D}^{\circ}$, they would not be able to modify it. The indefinite article bir and demonstratives are ungrammatical with - $w$-clauses, because they 
all realize $\mathrm{D}^{\circ}$, hence they are mutually exclusive. As for the genitive subject case, since the genitive is assigned to possessors/subjects of $-w$-clauses in Spec,DP, it does not pose any problem to this analysis. The proposed structure of $-w$-clauses is presented in (131).

It is also noteworthy that $-w$-clauses, if they are object arguments in the matrix clause, are always marked with accusative. It is well-known that in Kazakh, similarly to other Turkic languages, there is differential object marking. That is, only (definite) DP objects bear overt accusative case, indefinite objects do not. Analyzing $-w$ - as $\mathrm{D}^{\circ}$ would immediately explain why $-w$-clauses must always bear overt accusative case: they are DP-s, so the accusative must be overtly marked on them.

(131) The structure of $-w$-headed non-finite clauses and subject case assigment

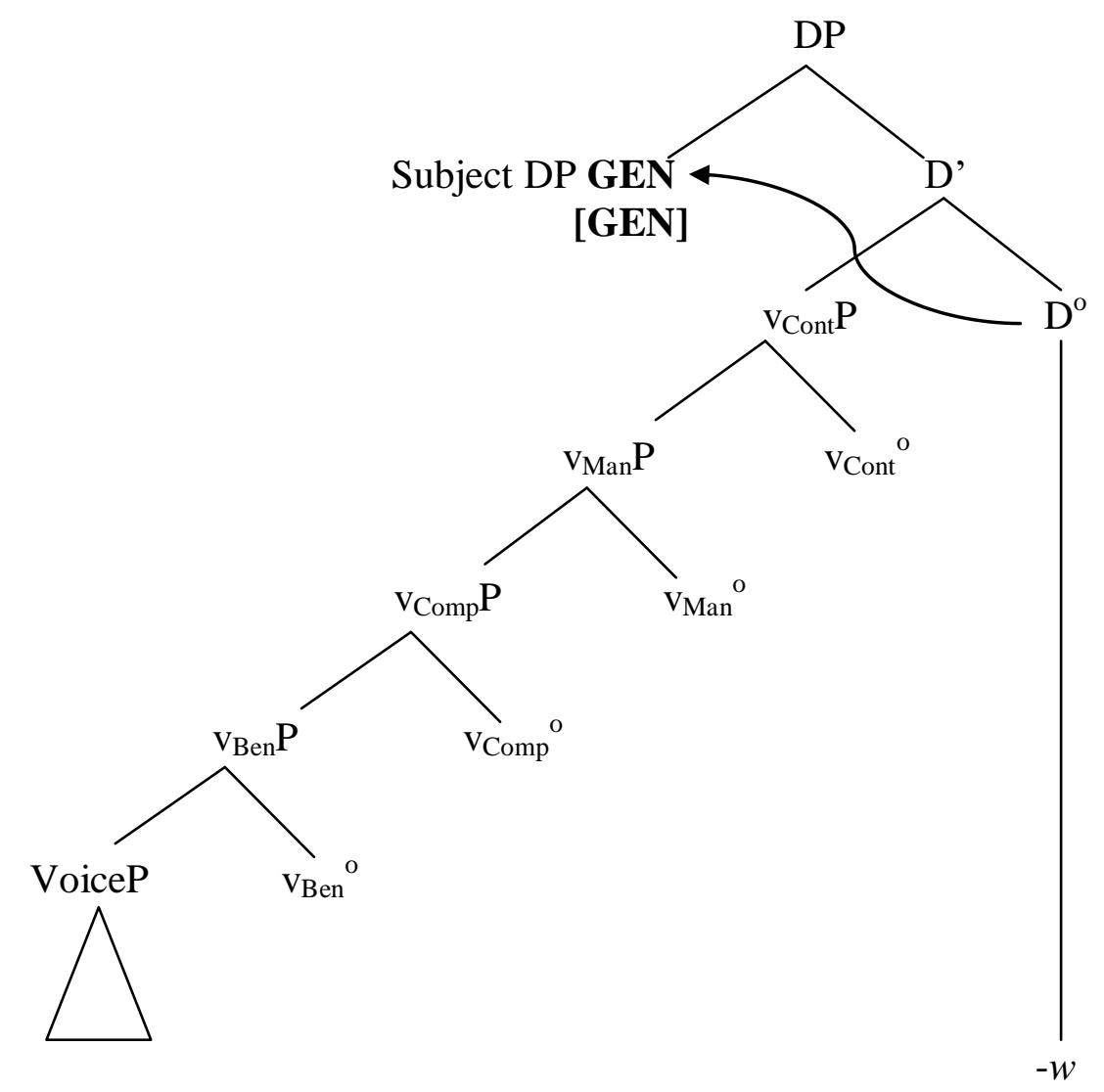




\subsubsection{Non-nominalized and nominalized $-\dot{G} A n$-type of clauses}

As it was demonstrated in 4.3 , there are salient differences between the agreement marking patterns between $-w$-clauses on one hand and $-\dot{G} A n,-y / A t I n,-(A) r$-clauses on the other. In this section, we will try to offer an analysis that can capture all the different patterns in the $-\dot{G} A n$ type of clauses: I claim that $-\dot{G} A n,-y / A t I n$ and $-(A) r$-clauses are not nominalized, but they can get nominalized. When they are nominalized, then their Inflection head is embedded by a Determiner head. This Determiner head may be relized by the suffix -LIq (for the discussion of the suffix see 4.4.4.1). That is, in Kazakh we find the suffix -LIq following the $-\dot{G} A n,-y / A t \operatorname{In}$ and $-(A) r$-headed non-finite clauses (in certain syntactic environments). (The phenomenon of -LIq-suffuxation was also noticed by e.g. Menges 1959: 483, Kenesbaev 1962: 325, Tažibaeva 2001: 31-33.) Moreover, I will show that in certain syntactic positions non-nominalized - $\dot{G} A n$-type of clauses, in other positions nominalized ones are used. In line with the reasoning about the agreement marking I made in the previous section, I will claim that the agreement marking can only be indicated after the nominalized $-\dot{G} A n,-y / A t I n$ and $-(A) r$-clauses. (Remember that above it was argued that the reason why the agreement can always be indicated on $-w$ clauses, is that they are nominalized.)

In the following, two important pieces of evidence will be presented in favour of the proposed analysis: in 4.4.4.2 it will be shown that the attachment of the suffix - LIq is only possible in non-finite clauses that are in "typical" noun phrase positions; moreover, in 4.4.4.3 we will see evidence that there is a correlation between the agreement marking and the occurrence of -LIq, and since, as I claim, the nominal agreement marking can only be present on nominalized clauses; this indicates that $-L I q$ indeed shows up in the nominalized $-\dot{G} A n$, $-y /$ AtIn and $-(A) r$-headed non-finite clauses.

\subsubsection{The suffix $-L I q$}

The suffix -LIq has six allomorphs: -lik, -lïq, -dik, -dïq, -tik, tïq. -LIq has numerous functions as a formative, for example, it can form abstract nouns (e.g. žürektilik 'braveness' < žürekti 'brave'). $-L I q$ is similar to $-D A y$ and $-\check{S} A$ in that it can select for nouns and other categories as well. In (132) it attaches to to a noun and the derived form elsilik 'embassy' is a noun too. (For more examples see Kenesbaev 1962: 138-139.) 
(132)

$\begin{array}{ll}\text { eл-ші }> & \text { ел-ші-лік } \\ \text { county-šI } & \text { county-šI-LIq } \\ \text { 'ambassador' } & \text { 'embassy' }\end{array}$

But $-L I q$ can follow not only nouns, but, for instance, adjectives as well. In examples (133) and (134) $-L I q$ is attached to derived adjectives: first the morpheme $-L I$ joins the stem forming an adjective, then $-L I q$ attaches deriving a noun.

(133) серпімді-лік (Kenesbaev 1962: 138-139)

resilient-LIq

'resilience, elasticity'

$\begin{array}{lll}\text { (134) жүрек-ті } & \text { жүрек-ті-лік (Kenesbaev 1962: 138-139) } \\ \text { heart-LI } & \text { heart-LI-LIq } \\ \text { 'brave' } & \text { 'braveness' }\end{array}$

These examples clearly show that $-L I q$ does not exclusively select for nouns. ${ }^{124}$

\subsubsection{The distribution of non-finite clauses followed by -LIq}

-LIq can only be attached to - $\dot{G} A n$-type of non-finite clauses if these are in certain syntactic positions. It is noteworthy that all the syntactic positions where $-\dot{G} A n$-clauses followed by -LIq can appear are typical noun phrase positions.

${ }^{124}$ It has to be mentioned that in the above examples - LIq derives nouns, but -LIq can derive adjectives as well. Such an example is given in (i).

(i) Ph.D. доктор-льқ жұмысс

$\mathrm{PhD}$ doctor-LIq work

'doctoral dissertation' (lit. 'PhD doctoral work') 


\subsection{Non-finite clauses followed by $-L I q$ in argument position}

$-\dot{G} A n$-type of clauses followed by $-L I q$ are acceptable in argument position. (Note that the presence of $-L I q$ does not ever seem to be obligatory, that is, it can be left out of the construction, without any change in meaning.) There were seven sentence-pairs in the questionnaire inquiring about clauses followed by $-L I q$ in argument position. (See: (15a)(15b), (16a)-(16b), (17a)-(17b), (18a)-(18b), (19a)-(19b), (20a)-(20b), (22a)-(22b) in

Questionnaire 2.) Their results are summarized in the following table.

(135) Grammaticality judgements about argument clauses with and without -LIq

\begin{tabular}{|c|c|c|}
\hline $\begin{array}{l}\text { The position the non-finite } \\
\text { clause occupies }\end{array}$ & $\begin{array}{l}\text { Number of speakers who } \\
\text { accepted the variant without } \\
\text {-LIq }\end{array}$ & $\begin{array}{l}\text { Number of speakers who } \\
\text { accepted the variant with } \\
\text {-LIq }\end{array}$ \\
\hline \multirow[t]{7}{*}{ Argument position } & (15a) $20 / 18$ & (15b) $20 / 10(2 \mathrm{QM})$ \\
\hline & (16a) $\mathbf{2 0 / 1 7}$ & (16b) 20/14 (1 QM; 1 NA) \\
\hline & (17a) 20/18 & (17b) 20/15 (3 QM) \\
\hline & (18a) 9/6 (1 QM) & (18b) $9 / 7$ \\
\hline & (19a) $\mathbf{2 0 / 1 7}$ & (19b) $20 / 16$ \\
\hline & (20a) 20/14 & (20b) $\mathbf{2 0 / 1 7}$ \\
\hline & (22a) 20/14 (1 QM) & (22b) 20/14 (1 NA) \\
\hline
\end{tabular}

Overall we can claim that both versions (i.e. with and without $-L I q$ ) are acceptable. But in some cases the variant without $-L I q$ was more preferred by the speakers than the one with $-L I q$ (see for example (15a) and (15b)). Further research is needed to determine what factors influence the acceptability of the -LIq-attached variants. ${ }^{125}$

In the following sentence-pairs the $-\dot{G} A n$ and $-y / A t I n$-headed non-finite clauses are in argument position: in (136) and (137) the $-\dot{G} A n$-clause is the direct object of ayt- 'to say', in (138) and (139) the $-y /$ AtIn-clause serves as a (nominal) predicate. Note that the only difference between the first and the second sentences in each pair is that in the second sentence -LIq attaches to the non-finite (cf. (137) and (139)).

\footnotetext{
${ }^{125}$ My personal impression is that the acceptability of - LIq-adjoinment is, at least party, a dialectal phenomenon. Speakers from South Kazakhstan tend to accept the -LIq-variants much more often than people from other parts of the country. If this is indeed so, then the reason for this dialectal difference might be language contact with other Turkic languages: in Uyghur and in Uzbek -LIq-adjoinment is very common.
} 
(136) Өмірбек [өткен апта-да Алмать-да бол-ван-ьын] aüm-mbl. 20/18

Ömirbek [last week-LOC Almatï-LOC COP-NF-POSS.3]ACC say-PAST.3

'Ömirbek said that he was in Almaty last week.'

(137)

Өмірбек [өткен апта Алматы-да бол-ван-дыс-ьин] aüm-mbl. 20/15 (3 QM)

Ömirbek [last week Almatï-LOC COP-NF-LIq-POSS.3]ACC say-PAST.3

'Ömirbek said that he was in Almaty last week.'

(138) Ең жақсы қ̧асиет-i- [ешкім-мен төбелес-іn,

SUPL good property-POSS.3 [nobody-INSTR fight-CV

сөз-ге кел-ме-йтін-і] еді. 20/17

word-DAT come-NEG-NF-POSS.3] COP.PAST.3

'His/Her best property was that (s)he did not fight or argue with anyone.'

(139) Ең жақ̆сы қ̧асиет-і- [ешкім-мен төбелес-іп,

SUPL good property-POSS.3 [nobody-INSTR fight-CV

сөз-ге кел-ме-йтін-діг-i] еді. 20/16

word-DAT come-NEG-NF-LIq-POSS.3] COP.PAST.3

'His/Her best property was that (s)he did not fight or argue with anyone.'

If the predicate of the non-finite argument clause is eken, the variants with or without -LIq are freely interchangeable. Eken is a copular form, which is used in argument non-finite clauses with a non-verbal predicate. So the forms eken $+($ Poss $)+$ [case licenced by the superordinate predicate $]$ and $e k e n+d I q+($ Poss $)+$ [case licenced by the superordinate predicate] (e.g. ekenin and ekendigin (both bear $3^{\text {rd }}$ person possessive + accusative suffix)) are interchangeable. An illustrative sentence-pair is given in (140) and (141): the former is without -LIq, the latter is with -LIq. 
(140) Медведев [Ресей-дің «Киото» протокол-ьнан

Medvedev [Russia-GEN Kioto Protocol-CM.ABL

шыв-y-bl мүмкін екен-ін] хабарла-дыл. (PC., based on NET-IKR)

go.out-NNF-POSS.3 possible COP.NF-POSS.3]ACC report-PAST.3

'Medvedev reported that there is a possibility that Russia will renounce the Kioto

Protocol.'

(141) Медведев [Ресей-дің «Киото» протокол-ьнан

Medvedev [Russia-GEN Kioto Protocol-CM.ABL

шыз-y-bl мүмкін екен-діг-ін] хабарла-ды. (NET-IKR)

go.out-NF-POSS.3 possible COP.NF-LIq-POSS.3]ACC report-PAST.3

'Medvedev reported that there is a possibility that Russia will renounce the Kioto

Protocol.'

\subsection{Complement clauses of semantic cases and postpositions followed by $-L I q$}

-LIq-attachment to non-finite clauses are acceptable if the non-finite clause is the complement of certain (but not all) semantic cases or postpositions (for details see the next section). Two illustrative sentence-pairs are given in (142)-(145), in which - LIq attaches to a - $\dot{G} A n$-headed non-finite clause that is the complement of the postposition twrali 'about' in example (143) and the semantic case $-D A y$ in (145). Note that these clauses, too, are grammatical without $-L I q$.

Путин-нің, баспасөз хатшы-сы [президент-тің, неке-ге тұр-zан-ьы] Putin-GEN press secretary-POSS.3 [president-GEN marriage-DAT stand-NF-POSS.3] тураль хабар-ды жоққа шызар-ды. 20/19

about news-ACC (refute)-PAST.3

'Putin's spokesman refuted the news about the president having gotten married.' 
(143) Путин-нің, баспасөз хатшы-сы ] [президент-тің неке-ге Putin-GEN press secretary-POSS.3 [president-GEN marriage-DAT тұр-ван-дыв-ыl] туральы хабар-ды жоққа шывар-ды. 20/20 stand-NF-LIq-POSS.3] about news-ACC (refute)-PAST.3

'Putin's spokesman refuted the news about the president having gotten married.'

(144) [Алла елші-сі-нің — істе-ген-ін]-дей істе. 20/15 (3 QM; 1 NA)

[Allah delegate-CM-GEN do-NF-POSS.3]-DAy do.IMP.SG2

'Act as Allah's delegate does.'

(145)\% [Алла елші-сі-нің — істе-ген-діг-ін]-дей істе. 20/12 (1 QM)

[Allah delegate-CM-GEN do-NF-LIq-POSS.3]-DAy do.IMP.SG2

'Act as Allah's delegate does.'

\subsubsection{3 - LIq and relative clauses}

On the other hand, the suffix $-L I q$ cannot attach to $-\dot{G} A n,-y / A t I n$ or $-(A) r$-headed relative clauses. In (146) the $-\dot{G} A n$-headed non-finite serves as a relative clause modifying the noun phrase bir toy 'a celebration'. In (147) and (148) $-L I q$ follows the - $\dot{G} A n$-headed relative clause, rendering it ungrammatical.

(146) [Әке-м-нің

арманда-ван] бір той-ьь om-mi. 20/16

[father-POSS.SG1-GEN dream-NF] one celebration-POSS.3 pass-PAST.3

'It was such a celebration that my father had dreamt of.'

(147) *[Әке-м-нің

арманда-ван-дыz-ы] бір той

өm-mi. 20/0

[father-POSS.SG1-GEN dream-NF-LIq-POSS.3] one celebration-POSS.3 pass-PAST.3

Intended: 'It was such a celebration that my father had dreamt of.'

(148) *[Әке-м

арманда-ван-дык] бір той

өm-mi. 20/0

[father-POSS.SG1 dream-NF-LIq] one celebration-POSS.3 pass-PAST.3

Intended: 'It was such a celebration that my father had dreamt of.' 
The results of Questionnaire 2 show that $-L I q$ can never show up attached to relative clauses. See sentences (37a)-(39c) in Questionnaire 2 and the following table, which summarizes the results. Note that the attachment of $-L I q$ was almost unanimously rejected by the native speakers.

(149) Grammaticality judgements about relative clauses with and without - LIq

\begin{tabular}{|c|c|c|}
\hline $\begin{array}{l}\text { The position the non-finite } \\
\text { clause occupies }\end{array}$ & $\begin{array}{l}\text { Number of speakers who } \\
\text { accepted the variant without } \\
\text { - LIq }\end{array}$ & $\begin{array}{l}\text { Number of speakers who } \\
\text { accepted the variant with } \\
\text { - LIq }\end{array}$ \\
\hline \multirow[t]{5}{*}{ Relative clause } & \multirow[t]{2}{*}{ (37a) 20/16 (1 QM; 1 NA) } & (37b) $20 / 1$ \\
\hline & & $(37 c) \mathbf{2 0 / 1}$ \\
\hline & (38a) 20/16 (1 NA) & (38b) 20/2 (1 NA) \\
\hline & \multirow[t]{2}{*}{ (39a) 20/16 } & (39b) 20/0 \\
\hline & & (39c) $20 / 0$ \\
\hline
\end{tabular}

As shown above, $-L I q$ can only attach to $-\dot{G} A n$-type of non-finite clauses if they are in argument position, or if they are complements of certain semantic cases/postpositions. On the other hand, clauses with -LIq are ungrammatical as relative clauses and as complements of (a different set from the above mentioned) semantic cases and postpositions (cf. below). It is curious that $-L I q$ appears in those positions that are generally occupied by noun phrases: the argument positions and complements of semantic cases/postpositions. Take (direct) objects for one (cf. in (150) alma 'apple' is a noun phrase), or complements of postpositions (cf. the postposition twrali 'about' in (151)).

Алма-нын жу!

apple-ACC wash.IMP.SG2

'Wash the apple!'

(151) [Киелі кітап] туралы қысқаша мәлімет (NET-KK)

[holy book] about short information

'short information about the Holy Book' 
In contrast, the modifying position of a noun phrase (i.e. that of a relative clause) is not a position for noun phrases; that is, relative clauses do not occupy a typical noun position, and so - LIq cannot attach to them.

These facts point to the conclusion that there is merit in treating $-L I q$ as an indicator of the nominalization.

\subsection{A short digression: non-finite clauses followed by $-L I q$ in other Turkic languages}

The attachment of $-L I q$ to non-finite clauses is not only the property of Kazakh. It is also found in the Southern Kipchak languages. (For the Southern Kipchak languages in general cf. Menges 1959: 483; for Kirghiz cf. Kasapoğlu Çengel 2005: 296 and Oruzbaeva \& Kudaybergenov 1964: 276.) It is also found in other Kipchak languages, as in Bashkir (Dimitriev 1948: 261-263) and in Kumük (Benzing 1959: 403-404). It seems to be quite common in Uzbek (Kononov 1960: 363, 369-374, 383) and in Modern Uyghur (Turki branch) as well (Rentzsch 2005: 143; Csató \& Uchturpani 2010: 73). It is found in Türkmen (Oghuz branch) as well (Clark 1998: 456, 480-483).

Moreover, the distribution of $-L I q$ in these languages seems ${ }^{126}$ to be the same as in Kazakh, i.e. it attaches to $-\dot{G} A n$-type of clauses ${ }^{127}$ in argument position ${ }^{128}$ and if the clause is the complement of (certain) semantic cases/postpositions. However, -LIq does not follow relative clauses (as Rentzsch (2005: 143) pointed it out for Modern Uyghur).

Türkmen is an interesting case: the suffix $-d I k /-l I k$ can attach to the $-y \bar{A} n,-A n,-j A k$ and -mAlI non-finite heads (Clark 1998: 480-483). (All of Clark's examples are in argument position.) What makes this construction peculiar, is that there is no -dIk-suffix in Türkmen

\footnotetext{
${ }^{126}$ Note that not all of the above mentioned references give an exhaustive description of the usage of -LIq in nonfinite clauses, but even if there is no detailed explanation, it is possible to make some deductions based on the examples they offer. (And the examples fit the above described pattern.)

${ }^{127}$ It is not impossible that $-L I q$ attaches to other non-finite heads as well, but it does not pose any problem for my discussion. (As it is the very rare Uzbek form -måklik (<-måk + -lik) (Kononov 1960: 369).)

${ }^{128}$ Menges (1959: 483) notes that in the Southern Kipchak languages (or with his term: die aralo-kaspische Gruppe), if the singular $3^{\text {rd }}$ person possessive suffix joins the non-finite - $\dot{G} A n$ morpheme, it is possible to add the suffix $-L I q$ to the $-\dot{G} A n$ head. He also makes the observation that the form with $-L I q$ is more common than the form without it. (This situation has changed in Kazakh, since he wrote his paper.)

In Uzbek -LIq can attach to -Gan, -(a)yattkan and -mas-headed clauses and the ekan copula, if the non-finite clause is in argument position (his term translates more like 'complement') (Kononov 1960: 363, 372-374). -Ganlik and -maslik-clauses can be the complements of the ablative semantic case forming causal complement clauses, and -maslik can be the complement of the dative (purpose clauses). -Ganlik can be the complement of the postposition učun 'for, in order to' as well, and the resulting clause will have causal semantics. The postposition učun can also have -maslik as its complement (purpose clauses) (Kononov 1960: 383).
} 
apart from this usage. The Türkmen formative which is cognate with the Kazakh suffix $-L I q$ is -lIk, i.e. the suffix initial / $1 /$ does not alternate. The alternation of the suffix initial / $1 /$ is a characteristic of Kipchak and South Siberian Turkic languages, and is not encountered in the Oghuz branch. Thus the Türkmen usage of - $d I k /-l I k$ following a non-finite clause is clearly a copied item from the Kipchak languages.

\subsubsection{Correlation between - LIq and the agreement marking}

Now we will turn to the second piece of evidence that supports that $-L I q$ is indeed in correlation with the nominalization of the clause. It will be demonstrated that there is a correlation between the possibility of $-L I q$-attachment and agreement marking on the nonfinite clause. (Remember that I assume that agreement can only be marked on nominalized clauses.)

In what follows, based on the results of Questionnaire 2, it will be shown that $-L I q$ adjoinment and the acceptability of the agreement marking are closely connected. (Questionnaire 2 includes 63 sentence-variants in different syntactic configurations inquiring about the correlation between $-L I q$ and the agreement marking.)

\subsection{In argument positions}

As discussed above (in 4.3.1), the agreement marking is obligatory in different-subject $-\dot{G} A n$ $(-y / A t I n$ or $-(A) r)$-headed argument clauses. Moreover, $-L I q$ can attach to $-\dot{G} A n,-y / A t I n$ or $-(A) r$-headed arg ument clauses. (For this see the results of the questionnaire in (135).) Thus in case of argument clauses the agreement marking and the -LIq-attachment seem to correlate with each other.

\subsection{In relative clauses}

In 4.3.2 we have shown that there are two major patterns in non-subject relative clauses: the agreement is either not indicated and the subject of the relative clause is in the nominative case, or the agreement is found on the target noun phrase and the relative clause's subject 
bears the genitive. Indicating the agreement on the relative clause's predicate is ungrammatical. Moreover, -LIq cannot follow relative clauses either. (See the table in (149).) Thus we see that when -LIq-attachment is ungrammatical, so is the marking of the agreement.

\subsection{As complements of semantic cases and postpositions}

Similarly to argument and relative clauses, there is a correlation between the acceptability of agreement marking and $-L I q$-attachment in case of $-\dot{G} A n$ and $-y / A t I n$-headed clauses that are complements of semantic cases/postpositions.

In 4.3.3 three groups $(\alpha, \beta, \gamma)$ were distinguished among these clauses based on the acceptability of the agreement marking. In the following these will be discussed one by one.

In the $\boldsymbol{\alpha}$-group the agreement is not allowed to be indicated. Complement clauses of the postpositions (-ABL) soy 'after' and sayïn 'every' (but there might be more postpositions) belong to this group. The attachment of $-L I q$ is not grammatical to the complement clauses of these postpositions. Thus in (152) and (153), in which the $-\dot{G} A n$-headed clauses are the complements of (-ABL) soy, it is ungrammatical to attach - LIq to the non-finite clause. (Cf. the grammatical sentences without $-L I q$ in (154) and (155).) Similarly, -LIq cannot follow the complement clause of sayïn, as illustrated in (156). (See also the grammatical (157).)

(152) *[Оқ̆ас-тың кел-ген-діг-i] соң клуб іс-і жандан-ды. 20/1

[Oqas-GEN come-NF-LIq-POSS.3] after club business-CM liven.up-PAST.3

'After Okas arrived, the business livened up.'

(153) *[Оқ̆ас-тың кел-ген-діг-i]нен

соң клуб іс- $i$ жандан-ды. 20/3

[Oqas-GEN come-NF-LIq-POSS.3]ABL after club business-CM liven.up-PAST.3

'After Okas arrived, the business livened up.'

(154) [Оқ̧ас кел-ген] соң клуб іс-і жандан-ды. 20/14 (2 QM; 1 NA)

[Oqas come-NF] after club business-CM liven.up-PAST.3

'After Okas arrived, the business livened up.'

(155) [Ок̧ас кел-ген]-нен соң клуб іс-i жандан-ды. 20/16 (1 QM)

[Oqas come-NF]-ABL after club business-CM liven.up-PAST.3 
'After Okas arrived, the business livened up.'

(156) *[Әиім-нің баяндама жаса-ван-дыz-ы] сайын, жұрт көп кел-еді. 20/2

[Äšim-GEN lecture make-NF-LIq-POSS.3] every people many come-PRES.3

Intended: 'Every time Ashim gives a lecture, many people come.'

(157) [Әшім баяндама жаса-ван] сайын, жұрт көп кел-еді. 20/19

[Äšim lecture make-NF] every people many come-PRES.3

'Every time Ashim gives a lecture, many people come.'

The questionnaire includes six sentence variants ${ }^{129}$ with (-ABL) son 'after' and four sentences $^{130}$ with sayin 'every'. The tables in (158) and (159) give the grammaticality judgements about these clauses. Notice the correlation between the possibility of agreement marking and -LIq: neither the agreement marking is acceptable, nor the attachment of -LIq.

(158) Grammaticality judgements about the complement clauses of the postposition soy

\begin{tabular}{|l|l|l|l|}
\hline $\begin{array}{l}\text { (Different subject) } \\
\text { complement clauses } \\
\text { of... }\end{array}$ & Without agreement & With agreement & With -LIq \\
\hline soy & $\mathbf{2 0 / 1 4}(\mathbf{2}$ QM; 1 NA) & $\mathbf{2 0 / 0}$ & $\mathbf{2 0 / 1}$ \\
\hline -ABL soy & $\mathbf{2 0 / 1 6 ( 1 ~ Q M ) ~}$ & $\mathbf{2 0 / 3}(\mathbf{1}$ QM) & $\mathbf{2 0 / 3}$ \\
\hline
\end{tabular}

(159) Grammaticality judgements about the complement clauses of the postposition sayï

\begin{tabular}{|l|l|l|l|}
\hline $\begin{array}{l}\text { (Different subject) } \\
\text { complement clauses } \\
\text { of... }\end{array}$ & Without agreement & With agreement & With -LIq \\
\hline sayïn & $\mathbf{2 0 / 1 9}$ & $\begin{array}{l}\mathbf{2 0 / 2}(\mathbf{1 ~ Q M}) \\
\mathbf{2 0 / 3}\end{array}$ & $\mathbf{2 0 / 2}$ \\
\hline
\end{tabular}

${ }^{129} \mathrm{Cf} .(29 \mathrm{a})-(29 \mathrm{f})$ in the questionnaire.

${ }^{130} \mathrm{Cf}$. (31a)-(31d) in the questionnaire.

${ }^{131}$ Complement clauses of the postposition -ABL soy 'after' pose an interesting issue: for three speakers the agreement marking was acceptable on the complement clause. It is striking that the very same three speakers accepted the sentence with -LIq. This clearly supports my claim that there is a connection between the agreement marking and $-L I q$ (despite the fact that these speakers were in minority compared to those who did not find the agreement marking grammatical). 
In the $\boldsymbol{\beta}$-group the marking of the agreement is "preferred". The postpositions twrali 'about' and üšin 'for, in order to', and the semantic instrumental case -Men were included from this group in the questionnaire. ${ }^{132}$ The results of the questionnaire show that the attachment of $-L I q$ is allowed in this group. In the following three examples, the non-finite clauses are the complements of twralï (in (160)), of üšin (in (161)) and of the instrumental semantic case (in (162)). In all three sentences attaching $-L I q$ to the non-finite clause is possible, as the numbers indicate following the sentences. (Note that fewer speakers accepted the - Men-sentence. However, this number is much higher than at the sentences from the $\alpha$ group.)

Путин-нің баспасөз хатшы-сы ] [президент-тің неке-ге

Pųtįn-GEN press secretary-POSS-3 [president-GEN marriage-DAT

тұр-ван-дыз-ы] тураль хабар-дыл жоққа шывар-ды. 20/20

stand-NF-LIq-POSS.3] about news-ACC (refute)-PAST.3

'Putin's spokesman refuted the news about the president having gotten married.'

(161) 112 адам [құжат-сыз ҚР-да тұр-ып жат-қ̧ан-дыг-bl]

112 person [document-WITHOUT QR-LOC stand-IP LV.CONT-NF-LIq-POSS.3]

үшін әкімшілік жауапкершілік-ке тарт-ыл-ды. 20/17

because.of administration charge-DAT pull-PASS-PAST.3

'Against 112 people were pressed legal charges, because they were staying in the Republic of Kazakhstan without any documents.'

(162) ?? [Әке-м-нің — негіз-гі тамыр-ы ақтөбе-лік бол-zан-дыв-ы]]-мен,

[father-POSS.SG1-GEN basis-ADJ origin-POSS.3 Aqtöbe-ADJ COP-NF-LIq-POSS.3]-INSTR туван жері Қарақалпақстан. 20/7 (1 QM)

be.born-NF place-POSS.3 Qaraqalpaqstan

'Although my father is essentially from Aktöbe, the place where he was born is Karakalpakstan.'

The following table gives the results of the questionnaire: the sentence variants without agreement marking are less preferred than those with the agreement (cf. the second and the

${ }^{132}$ See sentences (26a)-(26c) and (32a)-(35c) in the questionnaire. 
third columns). In the forth column the acceptability of the -LIq-sentences is given. Notice that in this group the $-L I q$-attachment is grammatical.

(163) Grammaticality judgements about the complement clauses of the different-subject - $\dot{G} A n$-clauses as complements of the $\beta$-type of semantic cases/ postpositions

\begin{tabular}{|c|c|c|c|}
\hline $\begin{array}{ll}\text { (Different } & \text { subject) } \\
\text { complement } & \text { clauses } \\
\text { of... } & \end{array}$ & Without agreement & With agreement & With $-L I q$ \\
\hline \multirow[t]{2}{*}{ twrali $^{133}$} & 20/7 (1 QM) & 20/14 (1 QM) & 20/12 (1 QM) \\
\hline & 20/4 (3 QM) & $20 / 19$ & $20 / 20$ \\
\hline \multirow[t]{2}{*}{$\ddot{u} \operatorname{šin}^{134}$} & 20/9 (1 QM) & 20/11 (3 QM) & 20/11 (3 QM; 1 NA) \\
\hline & $20 / 12$ & $20 / 19$ & $20 / 17$ \\
\hline$-M e n$ & 20/11 (1 QM) & 20/17 (1 QM) & 20/7 (1 QM) \\
\hline
\end{tabular}

Comparing the $\alpha$ and $\beta$-group (cf. tables (158), (159) and (163)), the results are striking. In the first group neither the agreement marking nor the usage of $-L I q$ was acceptable, while in the second group, in which the agreement marking is preferred, the - $L I q$-variant is accepted by a great majority of speakers.

In the $\gamma$-group (to which most of the semantic cases and postpositions belong) both the agreement marking and its absence is allowed. (But note that it seems that the agreementless variant is "more preferred".) The tables in (164) and (165) summarize the results of the questionnaire. ${ }^{135}$ The attachment of $-L I q$ is not strictly ungrammatical as it was in the $\alpha$-group or in relative clauses, but its acceptability is not as good as it was in the $\beta$-group either. This might be related to the fact that the agreement marking in this group is "less preferred".

\footnotetext{
${ }^{133}$ The results in the first line correspond to sentences (32a)-(32c), in the second line to (33a)-(33c) in the questionnaire.

${ }_{134}$ The results in the first line correspond to sentences (34a)-(34c), in the second line to (35a)-(35c) in the questionnaire.

${ }^{135}$ There was one more item that could belong here, in which the clause is the complement of the postposition -DAT šeyin 'until'. (See sentences (30a)-(30c) in the questionnaire.) However, the acceptance of the "intended" correct sentence did not reach the "grammatical level", so I excluded those examples from my discussion.
} 
(164) Grammaticality judgements about the complement clauses of the semantic locative case

\begin{tabular}{|l|l|l|l|l|}
\hline $\begin{array}{l}\text { (Different } \\
\text { subject) } \\
\text { complement } \\
\text { clauses of... }\end{array}$ & $\begin{array}{l}\text { Without } \\
\text { agreement }\end{array}$ & $\begin{array}{l}\text { With agreement } \\
\text { (the subject is in } \\
\text { the nominative) }\end{array}$ & $\begin{array}{l}\text { With agreement } \\
\text { (the subject is in } \\
\text { the genitive) }\end{array}$ & With -LIq \\
\hline$-D A$ & $\mathbf{2 0 / 1 8}$ & $\mathbf{2 0 / 1 5}(\mathbf{1}$ QM) & $\mathbf{2 0 / 8}(\mathbf{1}$ QM) & $\mathbf{2 0 / 5}(\mathbf{1}$ QM) \\
\hline
\end{tabular}

(165) Grammaticality judgements about the complement clauses of the semantic case -DAy

\begin{tabular}{|l|l|l|l|}
\hline $\begin{array}{l}\text { (Different subject) } \\
\text { complement clauses } \\
\text { of... }\end{array}$ & Without agreement & With agreement & With -LIq \\
\hline$-D A y^{136}$ & $\mathbf{2 0 / 1 5}$ & $\begin{array}{l}\mathbf{2 0 / 1 5}(\mathbf{3} \quad \text { QM; } \mathbf{1} \\
\text { NA })^{\mathbf{1 3 7}}\end{array}$ & $\mathbf{2 0 / 1 2}(\mathbf{1}$ QM) \\
& - & $\mathbf{2 0 / 1 0}(\mathbf{2}$ QM; 1 NA) & $\mathbf{2 0 / 1 1}$ \\
\cline { 2 - 5 } & - & &
\end{tabular}

Examples (166)-(168) illustrate that in the complement clause of -DAy both the agreement and its absence are acceptable (see (166) and (167)). Moreover, the attachment of -LIq is not (strictly) ungrammatical, shown in (168).

(166) [Алла елші-сі-нің —істе-ген-ін]-дей істе. 20/15 (3 QM; 1 NA)

[Allah delegate-CM-GEN do-NF-POSS.3]-DAy do.IMP.SG2

'Act as Allah's delegate does.'

(167) [Алла елші-сі істе-ген]-дей істе. 20/15

[Allah delegate-CM do-NF]-DAy do.IMP.SG2

'Act as Allah's delegate does.'

(168) \% [Алла елші-сі-нің $\quad$ істе-ген-діг-ін]-дей істе. 20/12 (1 QM)

[Allah delegate-CM-GEN do-NF-LIq-POSS.3]-DAy do.IMP.SG2

'Act as Allah's delegate does.'

\footnotetext{
136 The results in the first line correspond to sentences (27a)-(27c), in the second line to (28a)-(28b) in the questionnaire. Note that in the second line the variant without the agreement was not inquired about in the questionnaire, because that sentence variant originally appeared in a newspaper article.

${ }^{137}$ In this sentence the subject of the non-finite was in the genitive.
} 


\subsubsection{4 - $(A) r$-headed complement clauses of semantic cases and postpositions}

-(A)r-headed non-finite clauses in argument position and as relative clauses behave like $-\dot{G} A n$ and $-y /$ AtIn. However, as complement clauses of semantic cases or postpositions they do not seem to allow the agreement marking to be indicated. ${ }^{138}$ An illustrative example can be found in (169), in which the $-M A s$-headed ${ }^{139}$ clause is the complement of the postposition -ABL burï 'before' and the agreement marking on the -MAs-predicate renders the sentence ungrammatical.

(169) *[Oсы оқұива бол-мас-ы $]$ нан

бұрын Г.Каримова әке-сі-мен

[this event COP-NEG.NF-POSS.3]ABL before G.Karimova father-POSS.3-INSTR

хабарлас-ыл, Израиль-ге емдел-у-ге жібер-у-ін сұра-птьы. 20/5

communicate-CV İsrael-DAT recover-NNF-DAT send-NNF-POSS.3.ACC ask-EVID.3

Intended: 'Before this event, G. Karimova had been in touch with her father and requested to be sent to Israel to recover.'

\subsubsection{The proposed analysis}

I propose that $-\dot{G} A n,-y / A t I n$ and $-(A) r$-headed clauses are not nominalized non-finites, and because they are not nominalized the agreement marking cannot appear on their predicates. The non-nominalized $-\dot{G} A n,-y / A t I n$ and $-(A) r$ clauses are used in relative clauses, moreover certain postpositions (i.e. those of the $\alpha$-group) can only select for this type of non-finites, and the postpositions and semantic cases belonging to the $\gamma$-group prefer selecting for these. The tree in (170) represents the structure of the not nominalized - $\dot{G} A n$-type non-finite clauses: the non-finite Inflection head $\left(\mathrm{I}^{\circ}\right)$ attaches to the verb phrase that may consists of the $\mathrm{vP}$ and other verbal functional projections (up to the Continuous Phrase). These non-nominalized clauses can be selected by the $\alpha$ and $\gamma$-type postpositions/semantic cases, or they can be complements of the relative operator (found in relative clauses). The subjects of these clauses, as argued in Chapter 2, are in the nominative case.

\footnotetext{
${ }^{138}$ This is admittedly the least-clear type among the non-finite clauses discussed in this chapter. Further research might reveal that there are subtypes among the $-(A) r$-headed clauses with respect to agreement marking.

${ }^{139}-M A s$ is the negative allomorph of $-(A) r$.
} 
(170) The not nominalized $-\dot{G} A n,-y /$ AtIn and $-(A) r$-heded non-finite clauses and subject case assignment

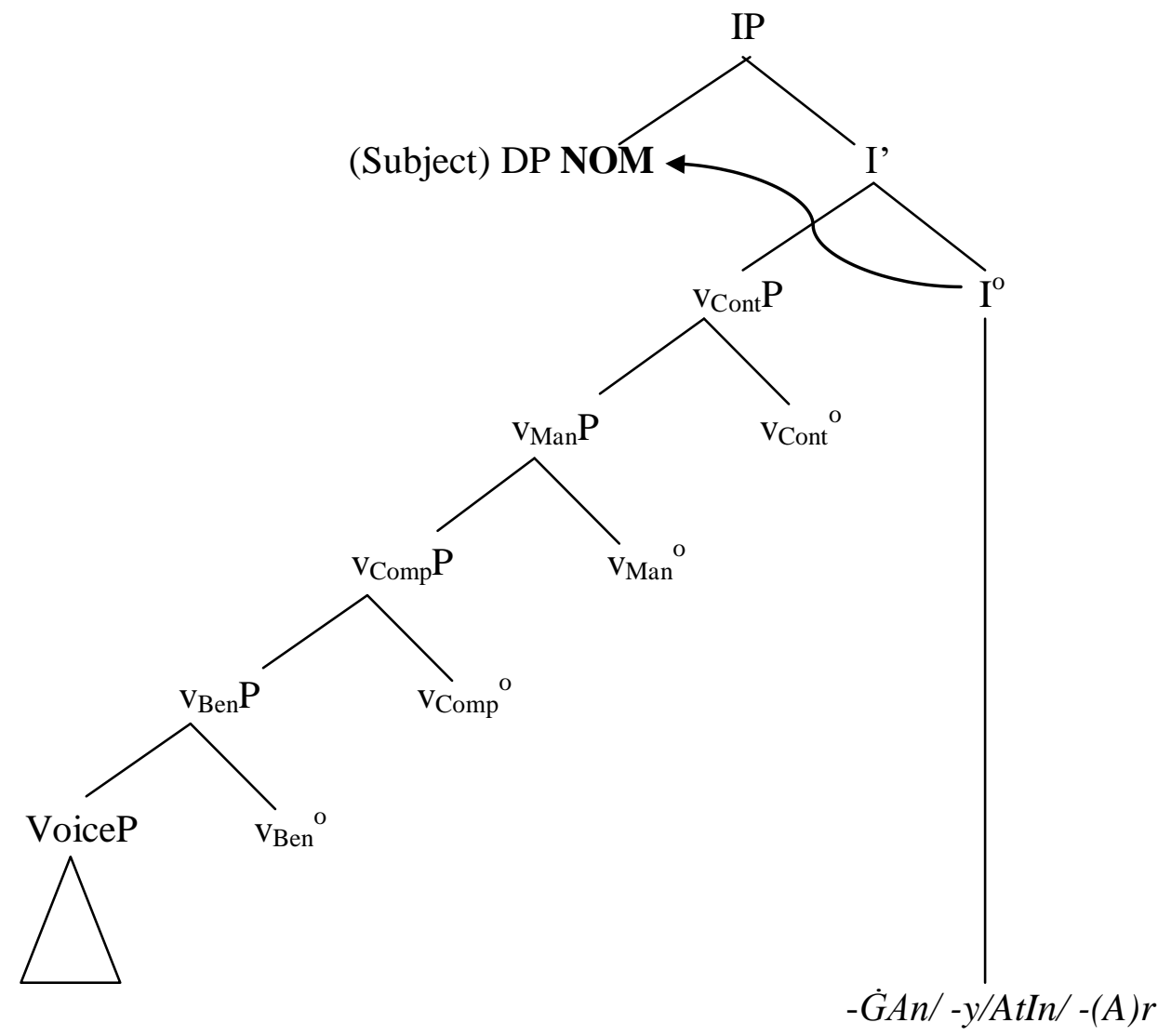

In argument positions only noun phrases (thus only nominalized non-finite clauses) can appear, moreover the $\beta$-type postpositions/ semantic cases prefer selecting for nominalized non-finites. In order to be able to get to these positions - $\dot{G} A n$-type of clauses have to be nominalized. I propose that $-L I q$ is a Determiner head $\left(\mathrm{D}^{\circ}\right)$ that attaches to Inflectional non-finite clauses nominalizing them. The fact that $-w$ and nominalized $-\dot{G} A n$ $(-y /$ AtIn and $-(A) r)$-clauses have the same properties, supports that $-L I q$ is a Determiner head. -LIq can be covert, i.e. it is not always indicated overtly, but the Determiner head is always present in the syntax. Furthermore, the agreement marking can be indicated on these clauses, because they are nominalized.

There is one more issue to deal with: the subject case assignment in nominalized Inflectional non-finites. As claimed above, the Inflection head can licence nominative case to its subject. Since in nominalized Inflectional non-finites a Determiner head is present too, which can assign genitive to its subject, subjects of nominalized Inflectional non-finite clauses seem to be assigned two subject cases (the nominative and the genitive), which is obviously 
not a desirable outcome. Note, however, that similar phenomena can be observed in other languages, too. For instance, Udmurt $-(e) m$-headed non-finite clauses resemble Kazakh Infinitival non-finite clauses in many aspects; but what is relevant for us here is the case when the $-(e) m$-headed clause is not nominalized (cf. the non-finite complement clause of the postposition bere 'after' in (171)), and its subject is nominative. However, when -(e)m-clauses become nominalized (cf. the -(e)m-headed argument clause in (172)), the "original" nominative subject case is overridden by the genitive or the ablative. ${ }^{140}$

(171) [Mon lykt-em] bere urok kutsk-i-z. (Georgieva, PC.)

[I(NOM) come-NF] after class(NOM) begin-PAST-3SG

'The class began after I (had) arrived.'

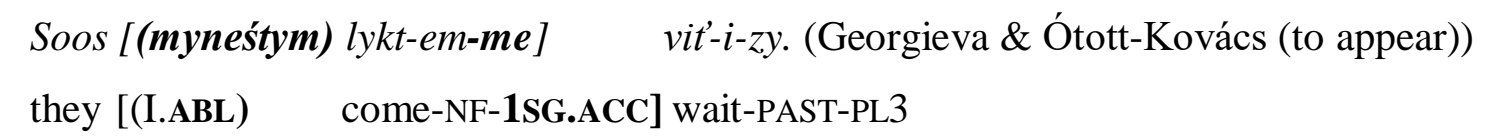

'They were waiting for me to come.'

Moreover, in Udmurt even finite clauses can get nominalized. ${ }^{141}$ In (173) the clause in square brackets is a subordinate clause, in which the predicate vera is a finite present form that assigns nominative to its subject. (Note that vera could be the predicate of a root clause, too.) This finite clause can be nominalized by the nominalizer $-(j) e z$, which appears to be the same in form as the singular third person possessive suffix; this is shown in (174). Note that in the nominalized clause in (174) the only grammatical subject case is the ablative, which is licensed by the nominalizer; the nominative would not be grammatical.
(173) Vala-m-e
$u g$
$l u$
understand-NF-1SG NEG.PRES(1SG) AUX(SG)
[Pet'a make vera]. (Georgieva, fieldwork)
[Petya(NOM) what.ACC say.PRES.3SG]
'I can't understand what Petya is saying.'

\footnotetext{
${ }^{140}$ In Udmurt possessors/subjects of possessive phrases are normally assigned the genitive case. However, if the possessive phrase is licensed an accusative case, its possessor/subject will be in the ablative.

${ }^{141}$ This is only possible in certain dialects of Udmurt, for instance in the Udmurt spoken in Tatarstan.
} 
(174) Vala-m-e

$u g$

$l u$

understand-NF-1SG NEG.PRES(1SG) AUX(SG)

[Pet'a-leś make vera-ze]. (Georgieva, fieldwork)

[Petya-ABL what.ACC say.PERS.3SG-NMNL.ACC]

'I can't understand what Petya is saying.'

Thus Udmurt presents a very clear-cut case when the nominative subject case is overridden by another subject case assigned by a nominalizer. I presume that Kazakh nominalized Inflectional non-finites are similar to Udmurt in this respect. The tree representation of Kazakh nominalized Inflectional non-finites is given in (175).

(175) Nominalized $-\dot{G} A n,-y /$ AtIn and $-(A) r$-headed non-finite clauses and subject case assignment

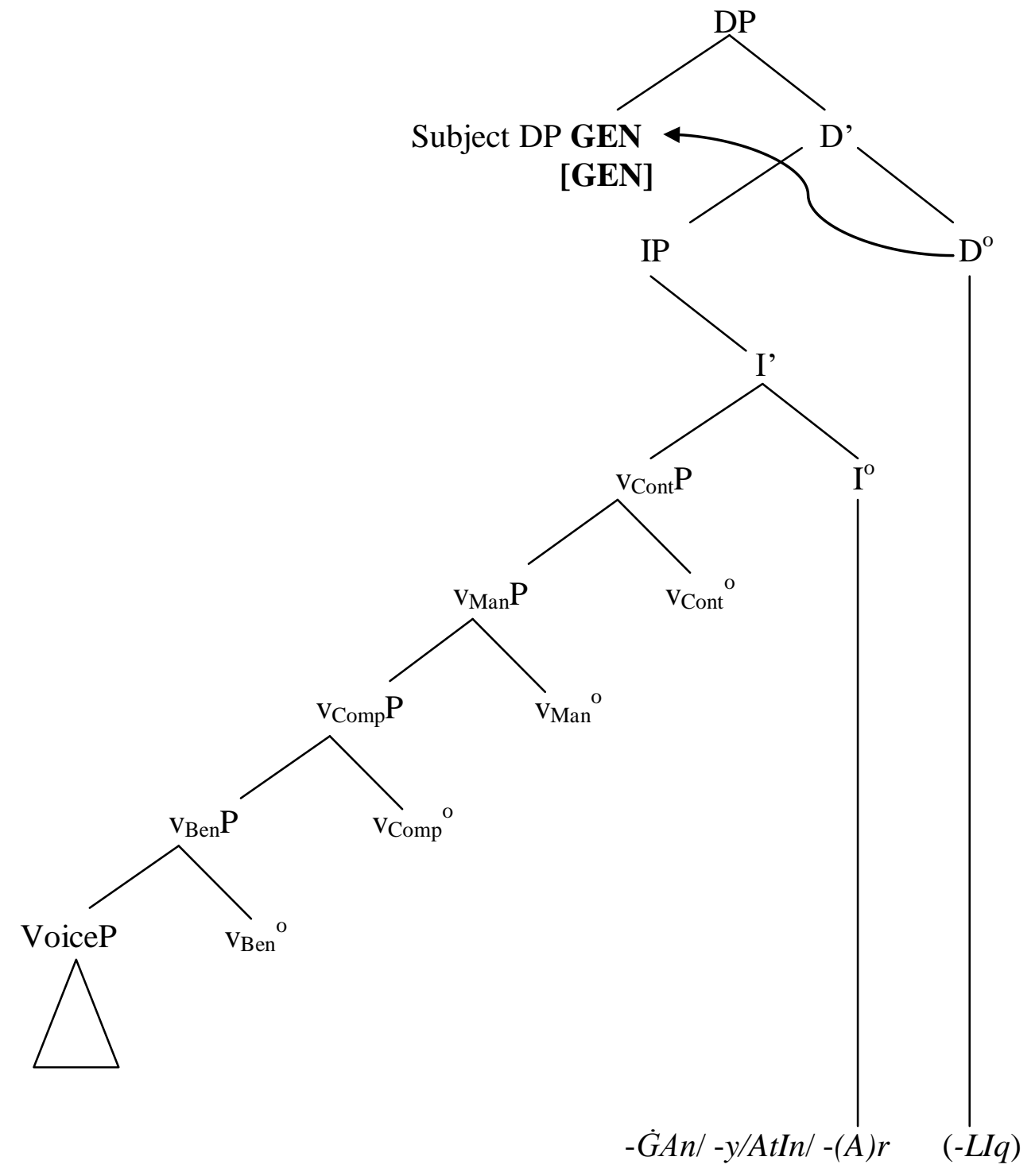




\section{Conclusions}

The syntax of Kazakh (and, in general, the Central Asian Turkic languages) has been a neglected area of research; there are only a few detailed descriptive works, and the number of theoretical works is even lower. The aim of my work has been to start filling in this void. Consequently, my main goal was to address questions that can provide a frame, a starting point for future research. Based on the Kazakh language material that I compiled, I tried to lay out some basic foundations which in the future more detailed accounts can be built upon. Let me summarize once again my main points.

In the Introduction, I showed that the main difference between Kazakh finite and nonfinite clauses is that the latter ones are truncated, that is, they lack functional categories such as Tense, and (polar) question operator, which are present in finite clauses. This claim gained further support in Chapter 2, in which the structure of Kazakh non-finite clauses was analyzed showing that non-finite clauses cannot be bigger than Inflection Phrase.

A major part of Chapter 2 was concerned with the constructions I called high light verbs (traditionally called auxiliaries). To my knowledge, I was the first to show that the groups of high light verbs are strictly ordered: Benefactives must be followed by Completives, which must precede Manner high light verbs, and the Continuous comes after all of them. (Naturally, not all of these high light verbs are present all the time.) This is summarized in table (1).

(1) The order of the groups of high light verbs

\begin{tabular}{|l|l|l|l|l|}
\hline & Benefactive & Completive & Manner & Continuous \\
\hline main & $-(I) p$ al - & $-(I) p$ qal- & $-y /$ A qoy- & $-(I) p$ žat - \\
verb & $-(I) p$ ber- & $-(I) p$ žiber- & $-y /$ A sal- & $-(I) p \check{z} \ddot{u r}-$ \\
& & $-(I) p$ tasta- & & $-(I) p$ oẗ̈r- \\
& & $-(I) p$ ket- & & $-(I) p$ tur- \\
\hline
\end{tabular}

After establishing this, it was shown that not all non-finite heads can embed high light verb phrases. Based on the results of Questionnaire 1, it was demonstrated that the non-finite head $-y / A$, which expresses manner, and $-(I) p$ when used to head manner clauses cannot follow high light verbs. In contrast, other non-finite heads can embed high light verb phrases, 
therefore I concluded that they are situated higher up in the structure, as shown in the following tables.

(2) The structure of Inflectional non-finite clauses

\begin{tabular}{|c|c|c|c|c|c|}
\hline Verb & Benefactive & Completive & Manner & Continuous & Inflection \\
\hline & $\begin{array}{l}-(I) p \text { al- } \\
-(I) p \text { ber- }\end{array}$ & $\begin{array}{l}-(I) p \text { qal- } \\
-(I) p \text { žiber- } \\
-(I) p \text { tasta- } \\
-(I) p \text { ket- }\end{array}$ & $\begin{array}{l}-y / A \text { qoy- } \\
-y / A \text { sal- }\end{array}$ & $\begin{array}{l}\text {-(I)p žat- } \\
\text {-(I)p žür- } \\
\text {-(I)p oẗ̈r- } \\
\text {-(I)p tur- }\end{array}$ & $\begin{array}{l}\text { Inflectional non- } \\
\text { finites: } \\
-\dot{G} A n, \quad-y / A t I n, \quad-(A) r \\
\text { Converbs: } \\
-(I) p, \quad-M A y, \quad-\dot{G} A l I, \\
-\dot{G} A s \operatorname{In},-M A y \operatorname{In} \check{S} A\end{array}$ \\
\hline
\end{tabular}

(3) The structure of nominalized clauses

\begin{tabular}{|l|l|l|l|l|l|}
\hline Verb & Benefactive & Completive & Manner & Continuous & Nominalizer \\
\hline & $-(I) p$ al - & $-(I) p$ qal - & $-y /$ A qoy- & $-(I) p \check{z}$ žt- & $-w$ \\
& $-(I) p$ ber- & $-(I) p$ žiber- & $-y /$ A sal- & $-(I) p$ žür- & $-(I) s$ \\
& & $-(I) p$ tasta- & & $-(I) p$ otïr- & \\
& & $-(I) p$ ket- & & $-(I) p$ tur- & \\
\hline
\end{tabular}

Thus it was shown in Chapter 2 that, not surprisingly, Kazakh non-finite clauses do not form a uniform class syntactically: there is group of clauses (the manner expressing $-y / A$ and $-(I) p$ ) which is more truncated than other non-finite clauses.

Moreover, I collected which non-finite clauses can have an overt independent subject, and which cannot. This is given in table (4). 
(4) Independent subjects in non-finite clauses

\begin{tabular}{|c|c|c|}
\hline $\begin{array}{l}\text { Can the clause have an } \\
\text { overt independent subject? }\end{array}$ & Non-finite heads & $\begin{array}{l}\text { Type (and meaning if } \\
\text { relevant) }\end{array}$ \\
\hline $\begin{array}{l}\text { yes } \\
\text { (when it expresses manner: } \\
\text { no) }\end{array}$ & $-(I) p$ & $\begin{array}{l}\text { Converb ('after', 'when'; } \\
\text { '-ing' (manner); 'and'; 'as'; } \\
\text { 'since', etc.) }\end{array}$ \\
\hline no & $-y / A$ & Converb ('-ing' (manner)) \\
\hline yes & $-M A y$ & $\begin{array}{l}\text { Converb (Negative } \\
\text { allomorph of }-(I) p \text { and }-y / A ; \\
\text { 'without'; 'until') }\end{array}$ \\
\hline yes & $-\dot{G} A l I$ & $\begin{array}{l}\text { Converb ('since'; 'in order } \\
\text { to') }\end{array}$ \\
\hline yes & $-\dot{G} A \operatorname{sIn}$ & Converb ('when'; 'because') \\
\hline yes & $-M A y \operatorname{In} \check{S} A$ & Converb ('unless', 'until') \\
\hline yes & $-w$ & Nominalizer \\
\hline yes & $-(I) s$ & Nominalizer \\
\hline yes & $-\dot{G} A n$ & Inflectional non-finite \\
\hline yes & $-y / A t \operatorname{In}$ & Inflectional non-finite \\
\hline yes & $-(A) r$ & Inflectional non-finite \\
\hline
\end{tabular}

We found a striking correlation between the availability of an overt independent subject and the degree of truncation: notice that only those clauses cannot have an independent subject (i.e. manner expressing $-y / A$ and $-(I) p$ ) whose head cannot embed high light verb phrases, i.e. these are the clauses which are more truncated. Moreover, I suggested, in line with the Minimalist Program approach, that the syntactic position of clause-heads and their capability to licence subject case are connected. That is, in Kazakh only those clauses can have independent subjects whose (clausal) head is in the Inflection slot, or whose head is a nominalizer. If the head of the clause is located below the Inflection position, the clause cannot have an independent subject, since that subject could not be licensed subject case. With this approach, we managed to explain why certain non-finite clauses do not have independent subjects.

Chapter 3 is different from the other chapters in that it focuses on only one vocabulary item, $-(I) p .-(I) p$-headed clauses are special as far non-finite clauses go, because syntactically 
and semantically clearly different clauses can be headed by one and the same vocabulary item $-(I) p$. I showed that there are (at least) four different syntactic constructions that $-(I) p$ can mark: low subordination, high subordination, low coordination and high coordination. Then I proposed that this wide range of usage can only be explained if we assume that $-(I) p$ is an underspecified vocabulary item, which can realize more than one syntactic configuration.

Chapter 4 analyzed non-converbial non-finite clauses. These clauses can appear as argument clauses, as complement clauses of postpositions/semantic cases, and (some of them) as relative clauses. First, I proposed that these clauses have two subtypes: nominalized and not nominalized, which I named "Inflectional non-finite", clauses; the table in (5) shows this classification. (It is noteworthy that my analysis of Kazakh was greatly influenced by Kornfilt's (2001a, 2003, 2006, 2007) works on similar Turkish non-finite clauses.)

(5) Heads of nominalized and non-nominalized non-finite clauses (first version)

\begin{tabular}{|l|l|}
\hline Nominalized clauses & $-w,-(I) s,(-M A q)$ \\
\hline (Non-nominalized) Inflectional non-finites & $-\dot{G} A n,-y / A t \operatorname{In},-(A) r$ \\
\hline
\end{tabular}

The syntactic behaviour of these clauses supports this classification. For instance, if an -wheaded nominalized clause modifies a noun head, as shown in (6), the compound marker $-(s) I$ appears on the modified noun head, which is exactly the same pattern that can be observed in case of nominal compounds (cf. (7)). However, when Inflectional non-finites modify a noun phrase, the compound marker is absent (cf. (8)), indicating that these non-finite constructions are not nominalized. In Chapter 4, other criteria were offered, too, supporting the classification in (5).

(6) [«Коста Конкордиа»кеме-сін көтер-у] жұмыс-тар-ы

[Kosta Konkordịa ship-CM.ACC raise-NNF] work-PL-CM

аяқтал-ды. (NET-T24)

finish(intr)-PAST.3

'The works of lifting the ship Costa Concordia have come to an end.'

(7) $\quad \check{\text { }}$ жұмыс-ы

house work-CM

'housework' 
(8) Маван [демалыс кун-дер-і істе-йтін] жұмыс керек еді. (NET-SZH)

I.DAT [rest day-PL-CM do-NF] work necessary COP.PAST.3

'I would need a job that can be done on the weekends.'

Moreover, I needed to account for the fact that some $-\dot{G} A n(-y / A t I n$ and $-(A) r)$-clauses, which I claimed to be non-nominalized, can appear in typical nominal positions (such as in argument position or as complements of certain semantic cases/postpositions) with nominal agreement (i.e. the possessive) marked on their predicates. This seemingly contradicts the classification in (5). However, it was demonstrated in Chapter 4 that the originally nonnominalized $-\dot{G} A n$ ( $-y /$ AtIn and $-(A) r)$-clauses can get nominalized, which allows them to appear in the above mentioned "typical" nominal positions. In Kazakh the suffix $-L I q$ can appear following (certain types of) $-\dot{G} A n(-y / A t I n$ and $-(A) r)$-clauses; an illustrative example is given in (9).

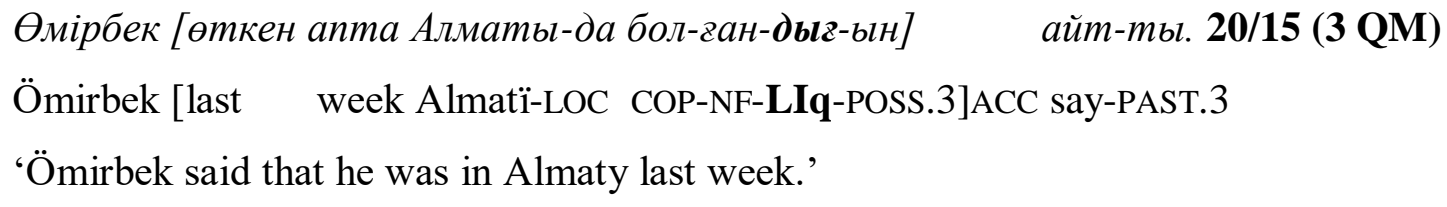

I showed that $-L I q$ is nominalizer that turns the originally non-nominalized Infinitival nonfinites into nominalized clauses. More than 60 sentences of Questionnaire 2 were concerned with the possibility (and details) of $-L I q$-attachment. The results are summarized in the following table. 
(10) Possibility of -LIq-attachment

\begin{tabular}{|l|l|}
\hline $\begin{array}{l}\text { Function of the }-\dot{G} \boldsymbol{A n} /-\boldsymbol{y} / \boldsymbol{A t I n} / \mathbf{-}(\boldsymbol{A}) \boldsymbol{r} \text {-headed } \\
\text { clause }\end{array}$ & Can $-\boldsymbol{L I q}$ follow the clause? \\
\hline Relative clause & no \\
\hline Argument clause & yes \\
\hline $\begin{array}{l}\text { Complement of a semantic case/postposition } \\
(\alpha)^{142}\end{array}$ & no \\
\hline $\begin{array}{l}\text { Complement of a semantic case/postposition } \\
(\beta)^{143}\end{array}$ & yes \\
\hline $\begin{array}{l}\text { Complement of a semantic case/postposition } \\
(\gamma)^{144}\end{array}$ & $?$ \\
\hline
\end{tabular}

These results indicate that $-L I q$ can only show up following clauses in typical nominal positions (cf. the ungrammaticality of $-L I q$-attachment after relative clauses, but the acceptability after argument clauses; the latter being a typical nominal position).

A further argument formulated in Chapter 4 was that nominal agreement marking can only be marked on predicates of nominalized clauses, but not on non-nominalized clauses. First, I provided a detailed dataset of agreement marking patterns in non-finite clauses based on the Kazakh corpus I compiled and Questionnaire 2, which will hopefully be useful for Kazakh descriptive linguistics, too. Moreover, interesting correspondences can be discovered between nominalization and the grammaticality of nominal agreement marking (cf. the table in (11)).

\footnotetext{
${ }^{142}$ Complement clauses of the following postpositions belong to this group: -(ABL) soy 'after', saÿ̈ 'every'.

${ }^{143}$ Complement clauses of the following postpositions/semantic cases belong to this group: twrali 'about', üšin 'for; in order to', -Men (INSTR semantic case)

${ }^{144}$ Complement clauses of the remaining postpositions/semantic cases belong to this group, such as locative, dative, ablative, $-\check{S} A,-D A y,-\mathrm{ABL}$ keyin 'after', etc.
} 
(11) Agreement marking patterns in non-finite clauses

\begin{tabular}{|l|l|}
\hline Non-finite clause type & $\begin{array}{l}\text { Can the nominal agreement marking be } \\
\text { present on the non-finite predicate? }\end{array}$ \\
\hline Converb clauses & no \\
\hline (nominalized) $-w$-clauses & yes \\
\hline (nominalized) $-(I)$-clauses & yes \\
\hline $\begin{array}{l}\text { Relative clauses (headed by }-\dot{G} A n /-y / A t I n / \\
-(A) r)\end{array}$ & no \\
\hline $\begin{array}{l}\text { Argument clauses (headed by }-\dot{G} A n /-y / A t I n / \\
-(A) r)\end{array}$ & yes \\
\hline $\begin{array}{l}\text { Complement clauses of a semantic } \\
\text { case/postposition }(\alpha)\end{array}$ & no \\
\hline $\begin{array}{l}\text { Complement clauses of a semantic } \\
\text { case/postposition }(\beta)\end{array}$ & yes \\
\hline $\begin{array}{l}\text { Complement clauses of a semantic } \\
\text { case/postposition }(\gamma)\end{array}$ & (preferred:) no \\
\hline
\end{tabular}

The nominal agreement can be marked on predicates of the clauses that I analyzed as nominalized non-finites (cf. $-w,-(I) s$, and Argument $-\dot{G} A n /-y / A t I n /-(A) r$-clauses); but it cannot be indicated in converb clauses or on the predicate of relative clauses, which are nonnominalized clauses. $-\dot{G} A n,-y /$ AtIn and $-(A) r$-headed complement clauses of semantic cases/ postpositions have three subtypes, indicated by the notations $\alpha, \beta$ and $\gamma$. If we compare the relevant parts of tables (10) and (11), we will see that in those complement clauses which -LIq can be attached to, and which are consequently nominalized, the nominal agreement marking can be indicated (cf. $\beta$ ). On the other hand, those complement clauses where $-L I q$ cannot follow the agreement cannot be marked either (cf. $\alpha$ ). (Note that in group $\gamma$ the agreement marking, like the $-L I q$-attachment, is not preferred.) Therefore, there is a clear correlation between nominalization and agreement marking in Kazakh non-finite clauses.

To sum up, I argued in Chapter 4 that there are two types of non-converbial non-finite clauses in Kazakh: nominalized and non-nominalized non-finites, as shown in (12), which is a revised version of (5). $-\dot{G} A n,-y / A t \operatorname{In}$ and $-(A) r$-headed clauses are non-nominalized, but they can get nominalized through the attachment of -LIq. Moreover, I demonstrated that the agreement marking can only be indicated on nominalized non-finites. 
(12) Heads of nominalized and non-nominalized non-finite clauses (final version)

\begin{tabular}{|l|l|}
\hline Nominalized clauses & $-w,-(I) s,(-M A q) ;-\dot{G} A n(d I q),-y / \operatorname{AtIn}(d \operatorname{Iq})$, \\
& $-(A) r(l I q)$ \\
\hline (Non-nominalized) Inflectional non-finites & $-\dot{G} A n,-y / A t I n,-(A) r$ \\
\hline
\end{tabular}




\section{Bibliography}

Abish, Aynur (2014): Modality in Kazakh as spoken in China. Doctoral dissertation. Uppsala Universitet. Uppsala.

Adger, David (2003): Core syntax. A minimalist approach. Oxford.

Adger, David (2007): Three domains of finiteness: a Minimalist perspective. In. Nikolaeva, Irina (ed.) Finiteness. Theoretical and Empirical Foundations. Oxford - New York. 23-58.

Akbaba, Dilek Ergönenç (2011): Kazak ve Nogay Türkçesi Yazı Dillerinde Tasvir Fiilleri. Ankara.

Alexiadou, Artemis (2001): Functional Structure in Nominals. Nominalization and ergativity. Amsterdam/Philadelphia.

Alexiadou, Artemis \& Iordăchioaia, Gianina \& Cano, Mariángeles \& Martin, Fabienne \& Schäfer, Florian (2013): The realization of external arguments in nominalizations. Journal of Comparative German Linguistics. Vol. 16. 73-95.

Alexiadou, Artemis \& Iordăchioaia, Gianina \& Schäfer, Florian (2011): Scaling the variation in Romance and Germanic nominalizations. In. Sleeman, P. \& Perridon, H. (eds.) The Noun Phrase in Romance and Germanic. Structure, variation, and change. Amsterdam/Philadelphia. 25-40.

Alpysbaeva, Bayan et al. (1995): Kazakh Language Course for Peace Corps Volunteers in Kazakhstan. Almaty.

Amanžolov, Särsen (1994): Qazaq ädebi tili sintaksisinin qïsqaša kursï. Öydelip žäne tolïqtïrilip 2-basïlwï. Almatï. 
Aydemir, İbrahim Ahmet (2009): Konverbien im Tuwinischen. Eine Untersuchung unter Berücksichtigung des Altai-Dialekts. Wiesbaden.

Aygen, Gülşat (2002): Subject Case in Turkic Subordinate Clauses: Kazakh, Turkish and Tuvan. In. Hirotani, M. (ed.) Proceedings of the North East Linguistic Society 32. New York. 563-579.

Balakaev, Mäulen Balaqayulï (1959): Sovremennyj kazahskij âzyk. Sintaksis slovosočetaniâ i prostogo predloženiâ. Alma-Ata.

Balaqaev, Mäulen \& Isqaqov, Ahmet (1954): Qazirgi qazaq tili. Leksika, fonetika, grammatika. Almatï.

Bartos, Huba (2009): The syntax of Hungarian $-v A$ adverbial participles: A single affix with variable merge-in locations. In. É. Kiss, K. (ed.) Adverbs and Adverbial Adjuncts at the Interfaces. Berlin. 75-102.

Batayeva, Zaure (2013): Colloquial Kazakh. The Complete Course for Beginners. LondonNew York.

Benzing, Johannes (1959): Das Kumükische. In. Deny, J. et al. (eds.) Philologiae Turcicae Fundamenta 1. Wiesbaden. 391-406.

Biacsi, Mónika \& Mukuseva, Raushangul (selected, translated) (2011): A kán és a vezír. Kazak népmesék. Szeged.

Bianchi, Valentina (2003): On finiteness as logophoric anchoring. In. Guéron, J. \& Tasmovski, L. (eds.) Temps et point de vue/ Tense and Point of View. Nanterre. 213-246.

Bobaljik, Jonathan David (draft, 2011): Distributed Morphology. Available at: http://bobaljik.uconn.edu/papers/DM_ORE.pdf (Accessed on 19. 11. 2015.) 
Bowern, Claire (2004): (Some Notes on) Light Verbs and Complex Predicates in Turkic. In. Csirmaz, A. \& Lee, Y. \& Walter, M.A. (eds.) Proceedings of WAFL 1: Workshop in Altaic Formal Linguistics. MIT Working Papers in Linguistics. Volume 46. Cambridge, Massachusetts. 33-48.

Butt, Miriam (2010): The light verb jungle. Still hacking away. Available in PDF-format at: http://ling.uni-konstanz.de/pages/home/butt/ (Accessed on 19. 11. 2015.)

Published in: Amberber, M. \& Harvey, M. \& Baker, B. (eds.) Complex Predicates in CrossLinguistic Perspective. Cambridge. 48-78.

Butt, Miriam \& Lahiri, Aditi (2013): Diachronic pertinacity of light verbs. Lingua Vol. 135. 7-29.

Butt, Miriam \& Ramchand, Gillian (2005): Complex Aspectual Structure in Hindi/Urdu. In. Erteschik-Shir, N. \& Rapoport, T. (eds.) The Syntax of Aspect. Oxford. 117-153.

Clark, Larry (1998): Turkmen Reference Grammar. Wiesbaden.

Clauson, Gerard (1972): An etymological dictionary of pre-thirteenth-century Turkish. Oxford.

Cristofaro, Sonia (2007): Deconstructing categories: finiteness in a functional-typological perspective. In. Nikolaeva, Irina (ed.) Finiteness. Theoretical and Empirical Foundations. Oxford - New York. 91-114.

Csató, Éva Á. (2010): Two types of complement clauses in Turkish. In. Boeschoten, H. \& Rentzsch, J. (eds.) Turcology in Mainz. (Turkologica Vol. 82.) Wiesbaden.

Csató, Éva, Á. \& Uchturpani, Muzappar, A. (2010): On Uyghur relative clauses. Turkic Languages. Vol. 14. 69-93. 
Demir, Nurettin (1998): On the status of a Turkish postverb. In. Johanson, L. et al. (eds.) The Mainz Meeting. Proceedings of the Seventh International Conference on Turkish Linguistics. August 3-6. 1994. Wiesbaden. 224-233.

Dimitriev, Nikolaj Konstantinovič (1948): Grammatika baškirskogo âzyka. MoskvaLeningrad.

Erdal, Marcel (2004): A grammar of Old Turkic. Leiden-Boston.

Erguvanl1-Taylan, Eser (1986): Pronominal versus Zero Representation of Anaphora in Turkish. In. Slobin, D.I. \& Zimmer, K. (eds.) Studies in Turkish linguistics. AmsterdamPhiladelphia. 209-232.

Ernst, Thomas (2002): The Syntax of Adjuncts. Cambridge.

Foley, William A. (2010): Clause linkage and Nexus in Papuan languages. In. Bril, I. (ed.) Clause Linking and Clause Hierarchy. Syntax and pragmatics. Amsterdam. 27-50.

Foley, William A. \& Van Valin, Jr. Robert D. (1984): Functional Syntax and Universal Grammar. Cambridge-London-New York-New Rochelle-Melbourne-Sydney.

Folli, Rafaella \& Harley, Heidi \& Karimi, Simin (2005): Determinants of event type in Persian complex predicates. Lingua Vol. 115. 1365-1401.

Georgieva, Ekaterina \& Ótott-Kovács, Eszter (2014): Nem-finit alárendelöi mellékmondatok a Volga vidéki nyelvi areában. Paper presented at LingDok (November 2014).

Georgieva, Ekaterina \& Ótott-Kovács, Eszter (to appear): Nem-finit alárendelői mellékmondatok a Volga vidéki nyelvi areában. In. Gécseg, Zs. (ed.) LingDok15. Nyelvészdoktoranduszok dolgozatai. Szeged.

Göksel, Aslı \& Kerslake, Celia (2005): Turkish. A comprehensive grammar. London-New York. 
Göksel, Aslı \& Kerslake, Celia (2011): Turkish. An essential grammar. London-New York.

Haig, Geoffrey (1998): Relative constructions in Turkish. Wiesbaden.

Hale, Ken (2002): On the Dagur Object Relative: Some comparative notes. Journal of East Asian Linguistics Vol. 11. 109-122.

Harley, Heidi \& Noyer, Rolf (1999): State-of-the-Article. Distributed Morphology. Glot International Vol. 4. (4). 3-9.

Haspelmath, Martin (2007): Coordination. In. Shopen, T. (ed.) Language typology and linguistic description. Second edition. Volume II: Complex Constructions. Cambridge. 1-51.

Huddleston, Rodney \& Pullum, Geoffrey K. (2006): Coordination and Subordination. In. Aarts, B. \& McMahon, A. (eds.) The Handbook of English Linguistics. Oxford. 198-219.

Jankowski, Henryk (2012): Kazakh in contact with Russian in modern Kazakhstan. Turkic Languages Vol. 16. 25-67.

Johannessen, Janne Bondi (1996): Partial Agreement and Coordination. Linguistic Inquiry Vol. 27. No. 4. 661-676.

Johanson, Lars (1975): Some remarks on Turkish 'hypotaxis'. Ural-Altaische Jahrbücher Vol. 47. 104-118.

Johanson, Lars (2012): Notes on Turkic stance particles. In.: Erdal, M. \& Nevskaya, I. \& Menz, A. (eds) Areal, historical and typological aspects of South Siberian Turkic. Wiesbaden. 51-58.

Johanson, Lars \& Csató, Éva Á. (1998): The Turkic Languages. London-New York.

Karimi, Simin (2013): Introduction. Lingua Vol. 135. 1-6. 
Kasapoğlu Çengel, Hülya (2005): Kırgız Türkçesi Grameri. Ses ve Şekil Bilgisi. Ankara.

Kažbulatova, Leyla Sabitovna (2011): Osnovy Grammatiki Kazahskogo Âzyka posobie dlâ načinâ̂िîh. Almaty.

Keenan, Edward, L. \& Comrie, Bernard (1977): Noun Phrase Accessibility and Universal Grammar. Linguistic Inquiry Vol. 8. 63-99.

Kenesbaev, Ismet K. (ed.) (1959): Qazaq tililiך tüsindirme sözdigi I-II. Almatï.

Kenesbaev, Ismet K. (ed.) (1962): Sovremennyj kazakskij âzyk. Fonetika i morfologiâ. AlmaAta.

Kenesei, István (1992): Az alárendelt mondatok szerkezete. In. Kiefer, F. (ed.) Strukturális magyar nyelvtan 1. Mondattan. Budapest. 529-713.

Kenesei, István (1994): Subordinate clauses. In. Kiefer, F. \& É. Kiss, K. (eds.) The Syntactic Structure of Hungarian. San Diego. 275-354.

Key, Greg \& Tat, Deniz (to appear): Structural Variation in Turkish Complex Predicates. In. Zeyrek, D. \& Sağın Şimşek, Ç. \& Ataş, U. \& Rehbein, J. (eds.) Ankara Papers in Turkish and Turkic Linguistics. Proceedings of the 16th International Conference on Turkish Linguistics. Wiesbaden.

Kirchner, Mark (1992): Phonologie des Kasachischen. Untersuchungen anhand von Sprachaufnahmen aus der kasachischen Exilgruppe in Istanbul. Wiesbaden.

Kirchner, Mark (1998a): Kazakh and Karakalpak. In. Johanson, L. \& Csató, É. Á. (eds.) The Turkic languages. London-New York. 318-332.

Kirchner, Mark (1998b): Kirghiz. In. Johanson, L. \& Csató, É. Á. (eds.) The Turkic languages. London-New York. 344-356. 
Koç et al. 2003 = Koç, Kenan \& Bayniyazov, Ayabek \& Başkapan, Vehbi (2003): Kazak Türkçesi Türkiye Türkçesi Sözlüğü. Ankara.

Koç, Kenan \& Doğan, Oğuz (2004): Kazak Türkçesi Grameri. İstanbul.

Kononov, Andrej Nikolaevič (1960): Grammatika sovremennogo uzbekskogo literaturnogo âzyka. Moskva-Leningrad.

Kornfilt, Jaklin (1996): On copular clitic forms in Turkish. In. Alexiadou, A. et al. (eds.) ZAS Papers in Linguistics. Vol. 6. Berlin. 96-114.

Kornfilt, Jaklin (1997): Turkish. London-New York.

Kornfilt, Jaklin (2001a): On the syntax and morphology of clausal complements and adjuncts in the Turkic languages. In. Bisang, W. (ed.) Aspects of Typology and Universals. Berlin 6382.

Kornfilt, Jaklin (2001b): Functional projections and their subjects in Turkish clauses. In. Erguvanlı Taylan, E. (ed.) The Verb in Turkish. Amsterdam-Philadelphia. 183-212.

Kornfilt, Jaklin (2003): Subject Case in Turkish nominalized clauses. In. Junghanns, U. \& Szucsich, L. (eds.) Syntactic Structures and Morphological Information. Berlin-New York. 129-216.

Kornfilt, Jaklin (2004): Remarks on Complex Predicates in a Comparative Altaic Perspective. In. Csirmaz, A. \& Lee, Y. \& Walter, M.A. (eds.) Proceedings of WAFL 1: Workshop in Altaic Formal Linguistics. MIT Working Papers in Linguistics. Volume 46. 1-14.

Kornfilt, Jaklin (2005): Agreement and its placement in Turkic Nonsubject Relative clauses. In. Cinque, G. \& Kayne, R. S. (eds.) The Oxford Handbook of Comparative Syntax. Oxford. $513-541$. 
Kornfilt, Jaklin (2006): Agreement: The (unique and local) syntactic and morphological licenser of the subject Case. In. Costa, J. \& Silva, M.C.F. (eds.) Studies on Agreement. Amsterdam-Philadelphia. 141-171.

Kornfilt, Jaklin (2007): Verbal and nominalized finite clauses in Turkish. In. Nikolaeva, Irina (ed.) Finiteness. Theoretical and Empirical Foundations. Oxford - New York. 305-332.

Kornfilt, Jaklin (2008): DOM and Two Types of DSM in Turkish. In. de Hoop, H. \& de Swart, P. (eds.) Differential Subject Marking. Dordrecht. 79-111.

Kornfilt, Jaklin (2009): Subject-Agreement correlations and their syntactic effects in some Turkic relative clauses. Turkic Languages Vol. 13. 70-96.

Krippes, Karl A. (1996): Kazakh Grammar with Affix List. Kensington, MD.

Kuno, Susumu (1973): The Structure of the Japanese Language. Cambridge, Massachusetts.

$\mathrm{KV}=$ Biacsi, Mónika \& Mukuseva, Raushangul (selected, translated) (2011): A kán és a vezír. Kazak népmesék. Szeged.

Lewis, Geoffrey L. (1975): Turkish. London.

Menges, Karl Heinrich (1959): Die aralo-kaspische Gruppe. In. Deny, J. et al. (eds.) Philologiae Turcicae Fundamenta 1. Wiesbaden.

Meral, Hasan Mesut (2012): Kazakh complex verb structures: A Distributed Morphology analysis. Turkic Languages Vol. 16. 239-256.

Nevskaya, Irina (2010): The Old Turkic Form -gAlI. In. Kappler, M. \& Kirchner, M. \& Zieme, P. (eds.) Trans-Turkic Studies. Festschrift in Honour of Marcel Erdal. İstanbul. 155166. 
Nikolaeva, Irina (2007): Introduction. In. Nikolaeva, Irina (ed.) Finiteness. Theoretical and Empirical Foundations. Oxford - New York. 1-19.

Oralbaeva, Nuržamal (1979): Qazaq tilindegi etistiktiฤ analitikalïq formanttarïnï qurïlïï men magïnasï. Almatï.

Oruzbaeva, Bübüyna \& Kudaybergenov, S. (eds.) (1964): Kïrgïz tilinin grammatikasï. Morfologiâ. Frunze.

Postal, Paul Martin (1998): Three Investigations of Extraction. Cambridge-London.

Pritsak, Omeljan (1959): Das Neuuigurische In. Deny, J. et al. (eds.) Philologiae Turcicae Fundamenta 1. Wiesbaden. 525-563.

Qapasova, Baqytgül Q. (compiled) (2004): Qazaqstan Respublikasïnïy Bilim žäne gïlïm Ministrligi usïngan Qazaq Tili Oqušï Anïqtamasï. 5-11 Sïnïptar. Astana-Almaty.

Qazïbaev, Sabïr (1971): Qazaq tili sabaqtas qurmalas söylemderin oqütwdïy tiimdi ädisteri. Muğalimderge arnalgan kömekši kural. Almatï.

QG = Žanpeyisov, Erbol (et al.) (2002): Qazaq Grammatikasï. Fonetika, Sözžasam, Morfologiya, Sintaksis. Astana.

Rentzsch, Julian (2005): Aspekt im Neuuigurischen. Wiesbaden.

Rizzi, Luigi (1997): The Fine Structure of the Left Periphery. In. Heageman, L. (ed.): Elements of Grammar. Handbook in Generative Syntax. Dordrecht-Boston-London. 281-338.

Schönig, Claus (1984): Hilfsverben im Tatarischen. Untersuchungen zur Funktionsweise einiger Hilfsverbverbindungen. Wiesbaden.

Somfai Kara, Dávid (2002): Kazak. Languages of the World/Materials 417. Lincom Europa. 
Straughn, Christopher A. (2011): Evidentiality in Uzbek and Kazakh. Doctoral dissertation. University of Chicago, Chicago.

Tanç, Mustafa (2002): Kazak Türkçesinde Zarf-Fiiller -Muhtar Evezov'un Tandamalı Engimeler Adlı Eseri Üzerinde Bir Çalışma- (Şekil-Anlam-İşlev ve Türkiye Türkçesindeki Karşıllıları). Doctoral Dissertation. Çukorova Üniversitesi, Sosyal Bilimler Enstitüsü, Türk Dili ve Edebiyatı Ana Bilim Dalı, Adana.

Tat, Deniz (2013): Word syntax of nominal compounds: Internal and aphasiological evidence from Turkish. Doctoral dissertation. University of Arizona.

Tažibaeva, Saule Ž. (2001): Kauzal'nye polipredikativnye konstrukcii kazahskogo âzyka. Sopostavitel'nyj aspekt. Novosibirsk.

Tažibaeva, Saule (2012): Polypredicative constructions of cause and consequence in Kazakh compared with Altay Turkic and Tuvan. In. Erdal, M. \& Nevskaya, I. \& Menz, A. (eds.) Areal, historical and typological aspects of South Siberian Turkic. Wiesbaden. 203-216.

Tekin, Talat (1968): A Grammar of Orkhon Turkic. The Hauge.

Tomanov, Marhabat (1981): Qazaq tiliniך tarihi grammatikasï. Fonetika, morfologiâ. Almatï.

Toosarvandani, Maziar (2015): The temporal interpretation of clause chaining in Northern Paiute. Manuscript available: http://people.ucsc.edu/ mtoosarv/papers/temporalinterpretation-clause-chaining.pdf (Accessed on 19. 11. 2015.)

Tóth, Ildikó (2000): VA- and VÁN- Participles in Hungarian. In. Alberti, G. \& Kenesei, I. (eds.) Papers from the Pécs Conference. Approaches to Hungarian 7. Szeged. 237-256.

Tumaševa, Dilyara Garifovna (1978): Xäzerge tatar ädebi tele. Morfologija. Kazan.

Ysqaqov, Ahmet (1964): Qazirgi qazaq tili. Morfologiâ. Universitetter men pedagogtïq instituttardï filologiâ fakultetterine arnalgan oqw qurali. Almatï. 
Ysqaqov 1967/I = Balaqaev, Mäulen \& Ysqaqov, Ahmet \& Qordabaev, Töleubay \& Hasenova, Aliya (eds.) (1967/I): Qazaq tilinin grammatikasï. Morfologiâ. Almatï.

Ysqaqov 1967/II = Balaqaev, Mäulen \& Ysqaqov, Ahmet \& Qordabaev, Töleubay \& Hasenova, Aliya (eds.) (1967/II): Qazaq tiliniy grammatikasï. Sintaksis. Almatï.

Ysqaqov, Ahmet (1974): Qazirgi qazaq tili. Morfologiya žoġarï oqw orïndarïnïy studentterine arnalgan oqwlïq. Almatï.

Ysqaqov, Ahmedi (1991): Qazirgi qazaq tili. Morfologiâ. Almatï.

Yüce, Nuri $\left(1999^{2}\right)$ : Gerundien im Türkischen. Eine morphologische und syntaktische Untersuchung. İstanbul. 


\section{Sources of the Kazakh examples}

Examples marked by the notation $\mathrm{KV}$ are from folktales taken from the following work:

Biacsi, Mónika \& Mukuseva, Raushangul (selected, translated) (2011): A kán és a vezír. Kazak népmesék. Szeged.

The list of folktales from which I quoted examples, and their notations are given below.

$\mathrm{KV}, \mathrm{AS}=A y \check{s} a$ sulw

$\mathrm{KV}, \mathrm{BP}=$ Bala patša

$\mathrm{KV}, \mathrm{HMV}=$ Xan men wäzir

$\mathrm{KV}, \mathrm{KQMM}=$ Köpes qüzï men molda

$\mathrm{KV}, \mathrm{QP}=Q w$ patša

$\mathrm{KV}, \mathrm{QUÖ}=$ Qarttïy ulïna ösi ${ }^{y}$ eti

$\mathrm{KV}, \mathrm{TB}=$ Tazša bala

KV, TTBS = Togïz Tonqïldaq, Bir Šinkildek

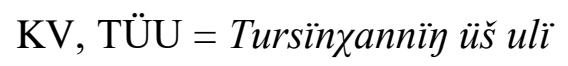

$\mathrm{KV}, \mathrm{UT}=U r$, toqpaq!

$\mathrm{KV}, \mathrm{ZEZET}=$ Žaqsï äyel žaman erkekti tüzeydi

Examples marked with the notation $\mathrm{M} / \mathrm{N}$ are taken from magazines, newspapers, textbooks. Their list is given bellow.

$\mathrm{M} / \mathrm{N}-\mathrm{AA}$

Araldïn apatï. [article] In. Žas Qazaq [magazine], 5. December 2014. (№49).

\section{$\mathrm{M} / \mathrm{N}-\mathrm{BB}$}

Bastangï balamasï. [article] In. Žas Qazaq [magazine], 5. December 2014. (№49).

\section{$\mathrm{M} / \mathrm{N}-\dot{\mathrm{GM}}$}

Ġabịt Müsirepov: Tịmka-Dịmka. In. Äbilqasïmova, K. et al. (2003): Qazaq Ädebi eti. Oqw Kitabï. Almatï. 87-90. 


\section{$\mathrm{M} / \mathrm{N}-\mathrm{GSB}$}

Galïm: Sayïn Borbasov [article] In. Žuldïzdar otbasï [magazine], May 2014. №10.

$\mathrm{M} / \mathrm{N}-\mathrm{IIA}$

Äbilqasïmova, K. et al. (2003): Qazaq Ädebi eti. Oqw Kitabï. Almatï. 42-43.

M/N-KMK

Közimnin mülde körmeytinin 4 žasïmda bildim. [article] In. Žastar üni [magazine], December 2014. (№12).

\section{M/N-MS}

Mağžan men Smag்ul. [article] In. Žas Qazaq [magazine], 5. December 2014. (№49).

\section{$\mathrm{M} / \mathrm{N}-\breve{S} \mathrm{M}$}

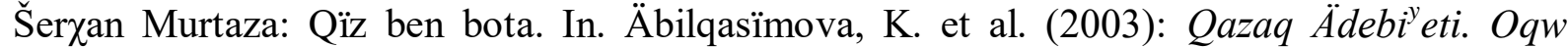
Kitabï. Almatï. 100-105.

Examples with the notation NET are taken from the Internet. These are given in the following.

NET-A Ä

http://naz8.blogspot.hu/

NET-AQT

http://aktobe.m.gosexpertiza.kz/kaz/node/3850

NET-AST

http://xxx.astana.kz/kk/node/72531

NET-ATV

http://astanatv.kz/news/show/id/32236.html 
NET-AZAT

http://www.azattyq.org/archive/news/20150201/330/330.html?id=26824025

NET-AZATR

http://www.azattyq.mobi/a/caucasus after the russian war in geogia/25070011.html

NET-BA

http://www.balalaralemi.kz/article/94/Bukil-zhamandyqtardyn-basy\#.VhZH0FTtmko

NET-BA2

http://www.balalaralemi.kz/article/151/Qarttyn-ulyna-osieti\#.VkSEdHovfIU

NET - BAQ

http://baq.kz/news/44390

NET-BAQ2

http://baq.kz/news/kogam/aielder-erlerge-karaganda-3-ese-kop-soileidi-eken-24175

NET-EAC

http://www.eurasiancommission.org/kk/act/integr_i_makroec/dep_makroec_pol/economyVie wes/Pages/default.aspx

\section{NET-EGOV}

http://blogs.e.gov.kz/en/blogs/kairbekova s/questions/259259

NET-I

https://www.interfax.kz/?lang=kaz\&int id=10\&news id=7087

NET-IKR

http://kazakh.irib.ir/

NET-KK

https://kkitap.net/ 


\section{NET-MKK}

https://massaget.kz/layfstayl/ezutartar/8677/

NET-ÖK

http://writers.kz/journals/?ID=10\&NUM=50\&CURENT=\&ARTICLE=1885

\section{NET-QO}

https://kyzylorda.mzsr.gov.kz/kk/node/271503

NET-24KZ

(http://bit.ly/16A1Njg)

\section{NET-KZIN}

http://www.inform.kz/rus/article/2193620

\section{NET-KZIN2}

http://www.inform.kz/kaz/article/2697873

\section{NET-N}

http://www.nur.kz/225024.html

\section{NET-SZH}

http://szh.kz/tag/\%D0\%BC\%D0\%B5\%D0\%BD+\%D1\%81\%D1\%82\%D1\%83\%D0\%B4\%D0 \%B5\%D0\%BD\%D1\%82\%D0\%BF\%D1\%96\%D0\%BD+\%D0\%BC\%D0\%B0\%D2\%93\%D0 \%B0\%D0\%BD+\%D0\%B4\%D0\%B5\%D0\%BC\%D0\%B0\%D0\%BB\%D1\%8B\%D1\%81+\%D 0\%BA\%D1\%83\%D0\%BD\%D0\%B4\%D0\%B5\%D1\%80\%D1\%96+\%D1\%96\%D1\%81\%D1 \%82\%D0\%B5\%D0\%B9\%D1\%82\%D1\%96\%D0\%BD+\%D0\%B6\%D2\%B1\%D0\%BC\%D1\% 8B\%D1\%81+\%D0\%BA\%D0\%B5\%D1\%80\%D0\%B5\%D0\%BA+\%D0\%B5\%D0\%B4\%D1\% $\underline{96}$

\section{NET-T24}

http://novostivideo.ru/video/916989 


\section{NET-TN}

http://m.tengrinews.kz/kaz/other/257257

\section{NET-TV7}

http://tv7.kz/kz/news/show/4410

\section{NET-WP}

http://kk.wikipedia.org/wiki/\%D0\%90\%D0\%BC\%D0\%B5\%D1\%80\%D0\%B8\%D0\%BA\%D 0\%B0\%D0\%BB\%D1\%8B\%D2\%9B \%D0\%9F\%D0\%B0\%D1\%80\%D0\%BB\%D0\%B0\%D0 \%BC\%D0\%B5\%D0\%BD\%D1\%82\%D1\%82\%D1\%96\%D0\%BA \%D0\%A4\%D0\%BE\%D1 $\% 80 \% \mathrm{D} 0 \% \mathrm{BC} \% \mathrm{D} 0 \% \mathrm{~B} 0 \% \mathrm{D} 1 \% 82$

\section{NET-ZhÖQ}

http://bilim-all.kz/article/2067-ZHigit-pen-onerli-qyz 


\section{Glosses}

\begin{tabular}{|c|c|}
\hline ABILIT & abilitive \\
\hline $\mathrm{ABL}$ & ablative \\
\hline AOR & aorist \\
\hline ACC & accusative \\
\hline ADJ & adjective \\
\hline ADV & adverb \\
\hline AUX & auxiliary \\
\hline CAUS & causative \\
\hline $\mathrm{CM}$ & compound marker \\
\hline COMPL.CV & complex converb morpheme \\
\hline COND & conditional \\
\hline COP & copula \\
\hline COP.NEG & negative copula (emes) \\
\hline COP.PAST & past copula (edi) \\
\hline COP.EVID & evidential copula (eken) \\
\hline COP.NF & non-finite copula (eken) \\
\hline $\mathrm{CV}$ & converb \\
\hline DAT & dative \\
\hline DEF & definite paradigm (in Hungarian) \\
\hline DEF.FUT & definite future $(-M A q)$ \\
\hline DISC.PART & discourse particle (dep) \\
\hline $\mathrm{EQV}$ & equative \\
\hline EVID & evidential \\
\hline FOC.PRES & focal present $(-w d A)$ \\
\hline FORML & formal \\
\hline GEN & genitive \\
\hline HAB.PAST & habitual past (finite $-y / A t I n$ ) \\
\hline IMP & imperative \\
\hline INDEF.FUT & indefinite future (finite $-(A) r$ ) \\
\hline INSTR & instrumental \\
\hline
\end{tabular}




\begin{tabular}{ll} 
INT.FUT & intentional definite future (finite $-M A q S \check{S}$ ) \\
LOC & locative \\
LV & light verb \\
LV.B & Benefactive light verb \\
LV.C & Completive light verb \\
LV.CONT & Continuous light verb \\
LV.M & Manner light verb \\
NEG & negative \\
NF & non-finite \\
NNF & nominalized non-finite \\
NMNL & nominalizer \\
NOM & nominative \\
OPT & optative \\
PART & (different kinds of) particles \\
PASS & passive \\
PAST & simple past \\
PERF & perfect \\
PL & plural \\
POL & polite form (used after imperatives) \\
POSS & possessive \\
PRES & present \\
PROGR & progressive \\
PROSP & prospective \\
Q & question particle \\
SG & singular \\
SUBJN & subjunctive \\
SUPERL & superlative \\
TEMP & temporal morpheme \\
\hline
\end{tabular}




\section{Tables and Notes}

\section{Table 1}

\begin{tabular}{|c|c|c|c|c|c|c|c|}
\hline & Benefactive & Completive & Manner & Continuous & Inflection & $\begin{array}{l}\text { Question } \\
\text { particle }\end{array}$ & $\begin{array}{l}\text { Tense } \\
\text { Copula }\end{array}$ \\
\hline \multirow[t]{3}{*}{ Verb } & \multirow[t]{3}{*}{$\begin{array}{l}-(I) p \text { al- } \\
-(I) p \text { ber- }\end{array}$} & \multirow[t]{3}{*}{$\begin{array}{l}-(I) p \text { qal- } \\
-(I) p \text { žiber- } \\
-(I) p \text { tasta- } \\
-(I) p \text { ket- }\end{array}$} & \multirow[t]{3}{*}{$\begin{array}{l}-y / A \text { qoy- } \\
-y / A \text { sal- }\end{array}$} & \multirow[t]{3}{*}{$\begin{array}{l}-(I) p \text { žat- } \\
-(I) p \text { žür- } \\
-(I) p \text { otïr- } \\
-(I) p \text { tur- }\end{array}$} & $\begin{array}{l}\text { Finite: } \\
-D I \\
-\dot{G} A n \\
-(I) p(t I) \\
-y / A t I n \\
-(A) r \\
-A / y(d I) \\
-\dot{G} A y \\
-M A q \\
-M A q \check{S} I \\
-w \check{S} I \\
-s A \\
\ldots\end{array}$ & $M A$ & $\begin{array}{l}\text { edi } \\
\text { eken } \\
\text { bolsa }\end{array}$ \\
\hline & & & & & $\begin{array}{l}\text { Inflectional non- } \\
\text { finites: } \\
-\dot{G} A n,-y / A t I n,-(A) r\end{array}$ & & \\
\hline & & & & & $\begin{array}{l}\text { Converbs: } \\
-(I) p,-M A y,-\dot{G} A l I, \\
-M A y \operatorname{In} \check{s} A,-\dot{G} A s I n, \\
-y / A \text { tura, }-y / A \text { sala, } \\
\text {-y/A bere, -y/A kele }\end{array}$ & & \\
\hline
\end{tabular}

Table 2

\begin{tabular}{|l|l|l|l|l|l|}
\hline & Benefactive & Completive & Manner & Continuous & Nominalizer \\
\hline Verb & $-(I) p$ al- & $-(I) p$ qal- & $-y / A$ qoy- & $-(I) p$ žat- & - w, $-M A q,-(I) s$ \\
& $-(I) p$ ber- & $-(I) p$ žiber- & $-y /$ A sal- & $-(I) p$ žür- & \\
& & $-(I) p$ tasta- & & $-(I) p$ otï- & \\
& & $-(I) p$ ket- & & $-(I) p$ tur- & \\
& & & & & \\
\hline
\end{tabular}

\section{Table 3}

\begin{tabular}{|l|l|l|l|}
\hline & $\begin{array}{l}\text { Question } \\
\text { Particle }\end{array}$ & $\begin{array}{l}\text { Tense } \\
\text { Copula }\end{array}$ \\
\hline $\begin{array}{l}\text { Noun/ } \\
\text { Adjecti } \\
\text { ve }\end{array}$ & $M A$ & $\begin{array}{l}\text { edi } \\
\text { eken } \\
\text { bolsa }\end{array}$ \\
\hline
\end{tabular}




\section{Some notes on the terms "Converbial tenses" and "Converbial agreement markers"}

There is a prevailing view in the literature that the suffixes which I mark here as $-(I) p(t I)$ and $-y / A(d I)$ are identical with the converb heads $-(I) p$ and $-y / A$, respectively. Moreover, it is claimed that these converbs are followed by a third agreement paradigm type, which is very similar to the z-paradigm (as discussed in Chapter 1), with the exception of the singular and plural third person agreement morpheme, which, according to the literature, following -(I)p and $-y / A$ is $-D I$. In (1) I give this supposed third agreement paradigm as it is dealt with in the literature. (QG: 516, Straughn 2011: 41, etc.)

(1) The supposed third agreement paradigm (supposedly used only after the "converbs" “-(I)p" and "- $y / A$ ")

$\begin{array}{ll}\text { SG.1 } & -M I n \\ \text { SG.2 } & -s I \eta \\ \text { SG.FORML } & -s I z \\ \text { SG.3 } & - \text { DI } \\ \text { PL.1 } & -M I z \\ \text { PL.2 } & -s I \eta d A r \\ \text { PL.FORML } & -s I z d A r \\ \text { PL.3 } & -D I\end{array}$

I would like to argue that the forms, as I refer to them, $-(I) p(t I)$ and $-y / A(d I)$ have nothing to do with the converbial suffixes $-(I) p$ and $-y / A$, and that $-D I$ (i.e. $-t I$ in $-(I) p(t I)$ and $-d I$ in $-y / A(d I))$ is not an agreement morpheme. Many reasons support this view, I shall start with the diachronic one.

The today Kazakh morphemes $-(I) p(t I)$ and $-y / A(d I)$ developed from the high light verb constructions -(I)p turur and - $y$ /A turur, in which the high light verb tur- (as a heavy verb 'to stand, stand up') is followed by the -ar allomorph of the aorist. That is, these constructions consisted of a high light verb construction (-(I)p tur- or $-y / A$ tur-, in which the converb headlike $-(I) p$ and $-y / A$ are in fact dissociated morphemes) and the aorist (Inflection) suffix. It is noteworthy that the agreement morphemes (of the z-paradigm) followed -(I)p turur and $-y / A$ turur, as it is expected after the aorist. We can see these forms in Old Turkic, where $-y /$ A tur(- 
$u r$ ) expressed durativity (Erdal 2004: 250-251), as illustrated in (2) (example taken from Erdal 2004: 250). Note that the so-called "vowel converb" (which is $-y / A$ in modern Kazakh) could have the form $-U$ in Old Turkic. (It had other forms too, but since they do not show up in example (2), they do not concern us now.)

(2) kut kol-u alkï̌s pašik ay-u tur-ur sizlär (ManBeicht 6)

happiness ask.for-U praise say-U LV-AOR PL.FORML

'You keep praying for grace and intoning blessings and hymns.'

The quite rare Old Turkic form -(I)p tur- was used "for referring to states reached after the end of the activity described by the lexical verb", i.e. it was similar to the (English) present perfect (Erdal 2004: 250). An example is offered in (3), quoted from Erdal 2004: 250.

(3) [...] kim ol örgin-niy öz-in täg

who that throne-GEN spirit-POSS.SG3 like

orto-sïn täg ... bol-up tur-ur-lar (BT V 175)

centre-POSS.SG3 like become-IP LV-AOR-PL

'[He has created the divine maidens and divine youths, ] who have become as the heart and centre ... of that throne.'

Later on, the segment turur began to reduce, and in the Middle Turkic Chagatai sources the phonologically reduced Dur occurs after the $-y / A$ or $-(I) p$-marked verb. Notice that the initial consonant in Dur shows variation (it can be $/ d /$ or $/ t /$, depending on the preceding sound's unvoicedness). In (4) and (5) the Chagatai forms corresponding to the Old Turkic $-y /$ A turur and $-(I) p$ turur are presented.

(4) Chagatai "Durative Present Tense" form of the verb tap- 'to find' (Bodrogligeti 2001: 237-240, Eckmann 1966: 174-176; example taken from Eckmann 1966: 174)

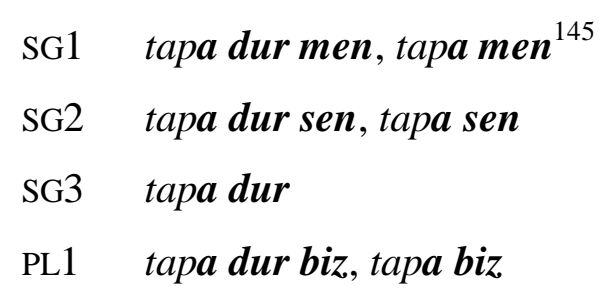

${ }^{145}$ Eckmann (1966: 174) and Bodrogligeti (2001: 243) note that the first and second person singular and plural forms often used without $d u r$. 
PL2 tapa dur siz, tapa siz

PL3 tapa durlar

(5) Chagatai "Present Perfect" from of the verb qül- 'to do' (Bodrogligeti 2001: 241-244, Eckmann 1966: 176-179; example taken from Eckmann 1966: 176-177)
SG1 qïlïp tur men, qülïp men ${ }^{146}$
SG2 qïlïp tur sen, qïlïp sen
SG3 qïlip tur/durur/turur
PL1 qïlip tur biz, qïlïp biz
PL2 qïlïp tur siz, qïlïp siz
PL3 qiï̈ turlar

Already in Chagatai the segment Dur $(<t u r-u r)$ could be absent in first and second persons. This is also characteristic to modern Kazakh. For the sake of lucidity, I will present the forms of Kazakh $-y / A(d I)$ and $-(I) p(t I)$ with their complete agreement paradigm in (6) and (7). (In (6) and (7) I separated the tense and agreement morphemes with hyphens from the verb and from each other, but they are spelled and pronounced as one word.) Notice that Kazakh -DI, following $-y / A$ and $-(I) p$ in third person, is the corresponding form of Chagatai Dur (and Old Turkic turur).

(6) $-y / A(d I)$-form of the verb tap- 'to find', 147 (in Kazakh)

$$
\text { SG.1 tab-a-mïn }
$$

SG.2 tab-a-sï

SG.FORML $\quad t a b-a-s \ddot{z}$

SG.3/PL.3 tab-adi

PL.1 tab-a-mïz

PL.2 tab-a-sïgdar

PL.FORML tab-a-sïzdar

(7) -(I)p(tI)-form of the verb qïl- 'to find' (in Kazakh)

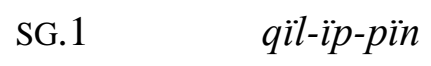

\footnotetext{
${ }^{146}$ Eckmann (1966: 177) and Bodrogligeti (2001: 243) note that the first and second person singular and plural forms often occur without tur.

${ }^{147}$ In Kazakh the word final - $p$ gets voiced if the suffix that attaches to the word starts with a vowel.
} 
SG.FORML

$$
q \ddot{i l}-\ddot{i p}-s \ddot{z} z
$$

SG.3/PL.3 qül-ïptï

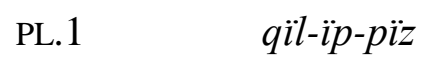

PL.2 qül-ïp-sï̈dar

PL.FORML qül-ïp-sïzdar

Thus from a diachronic perspective Kazakh $-D I$ that follows $-y / A$ and $-(I) p$ is not an agreement morpheme, it is the reduced form of the aorist-marked high light verb tur-.

There is also synchronic syntactic evidence in favour of -DI not being an agreement marker.

$-y / A(d I)$ and $-(I) p(t I)$ can be followed by Tense Copulas: $-y / A(d I)$ eken can express evidential habitual present, evidential general truths or evidential future; -(I)p(tI) edi is a past perfect form. If the copular tense morphemes are present, the agreement is marked after the copula; (8) shows this.

(8) $-y / A(d I)$ eken-marked form of the verb tap- 'to find' (in Kazakh)

SG.1 tab-adi eken-min

SG.2 tab-adï eken-siy

SG.FORML tab-adï eken-siz

SG.3/PL.3 tab-adi eken

PL.1 tab-adi eken-biz

PL.2 tab-adi eken-sigder

PL.FORML tab-adi eken-sizder

It is obvious that $-D I$ cannot be considered to be a third person agreement morpheme, because then the forms in (8) would be marked twice for agreement, once by -DI for third person, and secondly by the actual agreement morpheme following the copula. First of all, it is not possible in Kazakh to mark the agreement twice, moreover the alleged third person $(-D I)$ and the other agreement marking following the copula would be in conflict with each other. ${ }^{148}$

\footnotetext{
${ }^{148}$ It has to be mentioned that in $-(I) p(t I)$ edi the segment $-D I$ is deleted, as shown in (i). This does not undermine my claim that $-D I$ is not agreement, since there are other arguments in favour of my analysis. I assume that in $-(I) p(t I)$ edi the $-D I$-deletion is a phonological process.

(i) The -(I)p(tI) edi form of the verb ayt- 'to say, tell'

SG.1 ayt-ïp edi-m
} 
Thus we can conclude that $-D I$ is not an agreement morpheme, it is part of the morpheme realizing the Inflection head. (This is the reason why I indicate these forms as $-y / A(d I)$ and $(I) p(t I)$.) If they are followed by an agreement morpheme, -DI gets deleted (cf. (6) and (7)), which is a phonological process. If there is no agreement morpheme - in case of third person - following $-y / A(d I)$ or $-(I) p(t I),-D I$ is overt. The only difference between $-y / A(d I)$ and $(I) p(t I)$ is that the segment $-D I$ is deleted from $-(I) p(t I)$ if the Tense Copula edi follows it.

The third piece of evidence supporting my claim comes from the negated forms of the morphemes in question. It is well-known that the negative allomorph of the converbial $-y / A$ and $-(I) p$-heads is $-M A y$. That is, if negated, the converbs $-y / A$ and $-(I) p$ get conflated. This does not take place in the case of $-y / A(d I)$ and $-(I) p(t I)$. The negated form of $-y / A(d I)$ is $-M A y(d I)$, as it is expected. (The negative $-M A$ - suffix precedes the Inflection head, and following an item ending in a vowel, the $-y(d I)$ allomorph is used.) The negated form of $-(I) p(t I)$ is more remarkable: it is -MAp(tI) (cf. e.g. Kažbulatova 2009: 467-468, Koç \& Doğan 2004: 259). (9) illustrates the negation of the converb -(I)p, while (10) shows the negated form of $-(I) p(t I)$. This difference indicates that the converb head $-(I) p$ and the evidential $-(I) p(t I)$ are not the same.

bar-may $[\ldots]$

go-NEG.CV

'not going/ instead of going [...]'

(10) bar-ma-pti

go-NEG-EVID. 3

'(s)he didn't go (apparently/ so I've heard)'

To sum up, the finite forms $-y / A(d I)$ and $-(I) p(t I)$ are not "converbial tenses". As shown, $-D I$ is not an agreement morpheme following the converb heads $-y / A$ or $-(I) p$, but part of the vocabulary item, but it gets deleted in certain phonetic environments. If we accept that $-D I$ is part of the vocabulary item, the apparent similarity between the converbs $-y / A$ and $-(I) p$, and

\begin{tabular}{ll}
\hline SG.2 & ayt-ïp edi- $\eta$ \\
SG.FORML & ayt-ïp edi-yiz \\
SG.3/PL.3 & ayt-ïp edi \\
PL.1 & ayt-ïp edi-k \\
PL.2 & ayt-ïp edi-yder \\
PL.FORML & ayt-ïp edi-yizder
\end{tabular}


$-y / A(d I)$ and $-(I) p(t I)$ disappears. This is further supported by the fact that the negative allomorph of the converbial $-(I) p$ is different from the negation of $-(I) p(t I)$.

Diachronically the following process took place: originally $-y / A$ tur- and $-(I) p$ turwere high light verb constructions followed by the aorist (in the Inflection slot). Later the high light verb constructions "moved" to the higher Inflection slot, this was accompanied (or may be caused by) the phonological reduction of the aorist-marked high light verb. 


\section{Some notes on the transcription of the Kazakh examples}

Although there have been some efforts in the Republic of Kazakhstan to (re)introduce the Latin alphabet since the collapse of the Soviet Union, the Cyrillic alphabet is still used almost exclusively in every area of life. (See Jankowski 2012 for more detail about the so-far failed attempt to introduce the Latin alphabet in the Republic of Kazakhstan.) Note that there are Kazakh minority groups living in other countries which use a different script, for example, Kazakhs in China use the Arabic script. Since the present work is based on Kazakh as spoken (and written) in Kazakhstan, this is not going to be an issue for us.

Most linguistic works written on Kazakh outside of Kazakhstan use a transcription system that tries to render Kazakh examples in Latin script. There are different approaches to accomplish this task: one possibility is to use a script that captures the Kazakh examples based on their pronunciation (i.e. phonetic transcription). For instance, Abish (2014) uses such transcription in her work on Kazakh as spoken in China. The other way to render Kazakh examples in Latin script is to associate a Latin character to every single letter in the Kazakh Cyrillic alphabet (i.e. transliteration); for instance, the official Kazakh Latin alphabet is such. In most linguistic works, the Kazakh examples are transliterated (that is, not phonetically transcribed) into Latin script, but in some cases - which will be discussed presently - they take the pronunciation into consideration too. Hence I call this a mixed method.

The details of Latin transcription or transliteration systems may vary from author to author. I am not aware of a uniform, well-established transcription or transliteration system for Kazakh. The following table in (1) gives a sample about the more common or well-known Latin transliteration (and "mixed transliteration") systems. Note that these systems are either transliterations or follow the "mixed method". The Kazakh characters in the table which are not in bold are only used in Russian loanwords. The absence of certain capital letters indicates that the sound marked with that letter cannot be word initial.

In the second column the "mixed transliteration" of Doğan \& Koc (2004 : XVIII) is given, in parentheses I offer a slightly different version (as found in Koç et al. 2003: 19) of the aforementioned transliteration system. Authors writing in Turkish use this system (possibly with some minor variations): for example, Akbaba (2011) transliterates her examples as in Doğan \& Koç (2004), Tanç as in Koç et al. (2003). I am going to refer to this 
as Turkish transliteration. In the third column, Kirchner's (1992) mixed transliteration is presented, which I will call Turkological transliteration. Kirchner does not offer Latin equivalents for the letters that are only used in Russian loanwords, because he proposes that these loanwords should be transcribed according to the standard Latin transcription of Russian Cyrillic. Vajda (1994), on the other hand, transliterates those letters too, as given in the forth column. Finally, in the fifth column the official Kazakh Latin alphabet is shown, which basically transliterates the Kazakh Cyrillic alphabet into Latin script. ${ }^{149}$

\footnotetext{
${ }^{149}$ Note that having an official Kazakh Latin alphabet does not solve all the issues concerning the Latin transliteration. First of all, Kazakhs themselves are not familiar with this writing system, and secondly, it has the very same problems as other transliterations (see below my argumentation).
} 
(1) Kazakh Cyrillic alphabet and some orthography-based and mixed transcriptions

\begin{tabular}{|c|c|c|c|c|}
\hline $\begin{array}{l}\text { Letters in the } \\
\text { Kazakh Cyrillic } \\
\text { alphabet }\end{array}$ & $\begin{array}{l}\text { Transliteration } \\
\text { in Doğan \& Koç } \\
\text { 2004: XVIII. (In } \\
\text { parentheses: } \\
\text { transliteration in } \\
\text { Koç et al. 2003: } \\
\text { 19) } \\
\text { Turkish } \\
\text { transliteration }\end{array}$ & $\begin{array}{l}\text { Kirchner's } \\
\text { transliteration } \\
\text { (Kirchner 1992: } \\
\text { 4) } \\
\text { Turkological } \\
\text { transliteration }\end{array}$ & $\begin{array}{l}\text { Vajda's } \\
\text { transliteration }^{150}\end{array}$ & $\begin{array}{l}\text { Official Kazakh } \\
\text { Latin alphabet }\end{array}$ \\
\hline A a & $\mathrm{A} \mathrm{a}$ & $\mathrm{A} \mathrm{a}$ & $\mathrm{A} \mathrm{a}$ & $\mathrm{A} \mathrm{a}$ \\
\hline Ә ә & $\ddot{\mathrm{A}} \ddot{\mathrm{a}}$ & $\ddot{\mathrm{Ä}} \mathrm{ä}$ & $\ddot{\mathrm{Ä}} \mathrm{ä}$ & $\ddot{\mathrm{A}} \ddot{\mathrm{a}}$ \\
\hline Б б & $\mathrm{B} \mathrm{b}$ & B b & $\mathrm{B} \mathrm{b}$ & $\mathrm{B} \mathrm{b}$ \\
\hline B B & $\mathrm{V} v$ & & $\mathrm{~V} v$ & $\mathrm{~V} v$ \\
\hline$\Gamma \boldsymbol{\Gamma}$ & Gg & $\mathrm{Gg}$ & Gg & Gg \\
\hline F F & $\breve{G} \breve{g}$ & $\Gamma \gamma$ & $\breve{G} \breve{g}$ & $\breve{G} \breve{g}$ \\
\hline Д д & $\mathrm{Dd}$ & $\mathrm{Dd}$ & $\mathrm{Dd}$ & $\mathrm{Dd}$ \\
\hline E e & $\mathrm{E} \mathrm{e}$ & $\mathrm{E} \mathrm{e}$ & $\mathrm{E} \mathrm{e}$ & $\mathrm{E} \mathrm{e}$ \\
\hline$\ddot{\mathrm{e}}$ & yo & & $\ddot{\mathrm{e}}$ & yo \\
\hline Ж ж & $\mathrm{J} \mathrm{j}$ & Ž ž & $\check{Z} \check{Z}$ Ž & $\mathrm{J} \mathrm{j}$ \\
\hline 33 & $\mathrm{Zz}$ & $\mathrm{Zz}$ & $\mathrm{Zz}$ & $\mathrm{Zz}$ \\
\hline И и & $-1 y /-i y / i$ & Ïy/Iy ïy/iy & Ïy/Iy ïy/iy & Ï̈̈̈ \\
\hline Й й & Y y & Y y & Y y & Y y \\
\hline К к & K k & K k & K k & K k \\
\hline К к & $\mathrm{Qq}$ & Q q & $\mathrm{Qq}$ & $\mathrm{Qq}$ \\
\hline Л л & L 1 & L 1 & L 1 & L 1 \\
\hline М м & $\mathrm{M} \mathrm{m}$ & $\mathrm{M} \mathrm{m}$ & $\mathrm{M} \mathrm{m}$ & $\mathrm{M} \mathrm{m}$ \\
\hline Н н & $\mathrm{Nn}$ & $\mathrm{Nn}$ & $\mathrm{Nn}$ & $\mathrm{Nn}$ \\
\hline H & $\tilde{\mathrm{n}}$ & $y$ & $y$ & $\tilde{\mathrm{n}}$ \\
\hline O o & $\mathrm{O}$ o & $\mathrm{Oo}$ & $\mathrm{O}$ o & $\mathrm{O}$ o \\
\hline
\end{tabular}

\footnotetext{
${ }^{150}$ Vajda, Edward J. (1994): Kazakh Phonology. In Kaplan, E.H. \& Whisenhunt, D.W. (eds.) Opuscula Altaica: Essays Presented in Honor of Henry Schwarz. Bellingham, WA. 603-650. (Non vidi, taken from Straughn 2011: Xvi.)
} 


\begin{tabular}{|c|c|c|c|c|}
\hline$\overline{\boldsymbol{\theta} \theta}$ & Ö ö & Ö ö & Ö ö & Ö ö \\
\hline$\Pi_{\text {II }}$ & $\mathrm{Pp}$ & $\mathrm{Pp}$ & $\mathrm{Pp}$ & $\mathrm{Pp}$ \\
\hline $\mathbf{P} \mathbf{p}$ & $\mathrm{Rr}$ & $\mathrm{R} \mathrm{r}$ & $\mathrm{R} \mathrm{r}$ & $\mathrm{Rr}$ \\
\hline $\mathrm{Ce}$ & $\mathrm{S} \mathrm{s}$ & $\mathrm{S} \mathrm{s}$ & $\mathrm{S} \mathrm{s}$ & $\mathrm{S} \mathrm{s}$ \\
\hline$T_{T}$ & $\mathrm{Tt}$ & $\mathrm{Tt}$ & $\mathrm{Tt}$ & $\mathrm{Tt}$ \\
\hline $\mathbf{y} \mathbf{y}$ & $\begin{array}{l}\text { w, uw, üw (-uv/- } \\
\text { üv/-v) }\end{array}$ & $\begin{array}{l}(\mathrm{U}) \mathrm{w} /(\ddot{\mathrm{U}}) \mathrm{w} \\
(\mathrm{u}) \mathrm{w} /(\ddot{\mathrm{u}}) \mathrm{w}\end{array}$ & $\begin{array}{l}\text { W/Uw/Üw } \\
\text { w/uw/üw }\end{array}$ & $\mathrm{Ww}$ \\
\hline $\mathbf{Y}_{\mathbf{Y}}$ & $\mathrm{Uu}$ & $\mathrm{Uu}$ & $\mathrm{Uu}$ & $\mathrm{Uu}$ \\
\hline $\mathbf{Y}_{\mathbf{Y}}$ & $\ddot{U}$ ü & Ü ü & $\ddot{U}$ ü & $\ddot{U} \ddot{u}$ \\
\hline$\Phi \phi$ & Ff & Ff & F f & Ff \\
\hline $\mathbf{X}_{\mathbf{X}}$ & $\mathrm{X} \times(\mathrm{H} \mathrm{h})$ & $\mathrm{Xx}$ & $\mathrm{Xx}$ & $\mathrm{Xx}$ \\
\hline $\mathbf{h ~ h}$ & $\mathrm{Hh}$ & $\mathrm{Hh}$ & $\mathrm{Hh}$ & $\mathrm{Hh}$ \\
\hline Ц ц & Ts ts & & Ts ts & $\mathrm{Cc}$ \\
\hline Ч ч & Ç ç & & $\check{C} \check{c}$ & Ç ç \\
\hline Ш Ш & Ş ş & Š š & Š š & Ş ş \\
\hline Щ щ & Şç şç & & Šč šč & Şş ş ş \\
\hline $\mathrm{b}$ & hard sign & & $"$ & $"$ \\
\hline Ы ы & I 1 & İ̈̈̈ & $\ddot{I} \ddot{i}$ & I 1 \\
\hline I i & $\mathrm{I} \mathrm{i}$ & $\mathrm{I}$ i & $\mathrm{Ii}$ & İ i \\
\hline $\mathrm{b}$ & soft sign & & , & , \\
\hline Э э & $\mathrm{E} \mathrm{e}$ & & $\dot{\mathrm{E}} \dot{\mathrm{e}}$ & É é \\
\hline Ю ю & Yu yu & $\begin{array}{l}\text { Yuw/Yüw } \\
\text { yuw/yüw }\end{array}$ & $\mathrm{Yu} / \mathrm{Yü}$ yu/yü & Yw yw \\
\hline Я я & Ya ya & Ya/yä ya/yä & Ya ya & Ya Ya \\
\hline
\end{tabular}

In my opinion, the biggest problem of the transliteration systems is that some letters (namely $<_{\mathrm{H}}>$ and $\langle\mathrm{y}\rangle$ ) in the Kazakh Cyrillic alphabet denote more than one phonemes. (Note that in the majority of the cases their pronunciation depends on whether the word is a loanword or a "native", i.e. Turkic, word.) Thus two different phonemes correspond to each of these characters. While it is true that a genuine transliteration system does not aim to capture the pronunciation, using this system can lead to unrecognizability of certain words.

Let me illustrate this with a few examples: one of the problematic characters is $\left.<_{\mathrm{H}}\right\rangle$, which according to the Russian Cyrillic alphabet marks the sound /i/. In Kazakh, however, 
$<_{\mathrm{H}}>$ can be pronounced as $/ \mathrm{i}^{\mathrm{y}} /$ and $/ \mathrm{i}^{\mathrm{y}} /$ on one hand, ${ }^{151}$ or $/ \mathrm{i} /$ on the other. This is a crucial difference. Two examples, in which $<_{\mathbf{U}}>$ is pronounced as $/ \mathrm{i}^{\mathrm{y}} /$, are given below.

(2) $<$ ие $>/ \mathbf{i}^{\mathbf{y}} \mathrm{e} /$ 'master, owner'

(3) $<$ uic $>/ \mathbf{i}^{\mathbf{y}}$ is/ 'smell'

However, $<_{\boldsymbol{H}}>$ can also denote the sound $/ \mathrm{i} /$. This is the case in every loanword, that is, the Kazakh Cyrillic letter $<\mathrm{i}>$ does not come up in borrowed words. The following examples are loanwords in Kazakh. Notice that in these words /i/ is pronounced corresponding to the character $<_{\mathrm{H}}>$.

(4) <иман>/iman/ 'faith, belief'

(5) <изоглос> /izoglos/ 'isogloss'

There is a similar case with the Cyrillic letter $<y>$ too. This character has been rendered in different ways: in Turkological and Turkish transliterations it is generally represented as $\langle w\rangle$, $<\mathrm{uw}>$ or $<\ddot{\mathrm{u} w}>$. In native Turkic words in velar environments it sounds something like $/ \overline{\mathrm{u}} /$, in palatal environments like / $\overline{\mathrm{u}} /$ (Kirchner 1998: 322). However, in borrowed words the character $\langle y\rangle$ corresponds to the sound $/ \mathrm{u} /$. This is shown in the following examples: in the Turkic words in (6) and (7) the character $<y>$ renders the sound $/ \overline{\mathrm{u}} /$, while in $(8)$ it renders $/ \mathrm{u} / .{ }^{152}$

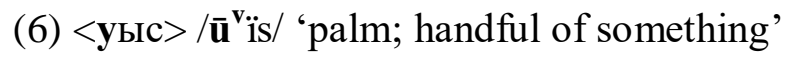

(7) <шолу> /šolū/ 'review, survey'

(8) <уролог> /urolog/ 'urologist'

\footnotetext{
${ }^{151}$ The difference between $/ \mathrm{i}^{\mathrm{y}} /$ and $/ \mathrm{i}^{\mathrm{y}} /$ is only that in the former the $/ \mathrm{i} /$ is palatal, in the latter velar.

It is also noteworthy that some authors (e.g. Kirchner (1998: 322)) described this sound as a long / $/ 1 /$. While there is truth to this characterization, in some environments the sound is clearly $/ \mathrm{i}^{\mathrm{y}} /$ or $/ \mathrm{i}^{\mathrm{y}} /$.

${ }^{152}$ An additional problem with transcribing the letter $\langle\mathrm{y}\rangle$ in loanwords as $\langle\mathrm{u}\rangle$ is that in such transcriptions the $\mathrm{u}$-sounds marked by the Cyrillic letters $\left\langle y>\right.$ and $<_{Y}>$ will conflate. However, these two u-sounds are two phonemes in Kazakh. Consider the following pair of words:

(i) уран 'uranium'

(ii) ұран 'slogan, banner'

Examples (i) and (ii) illustrate that there is a phonemic distinction between the two sounds. Note that the two sounds are different even to the "non-native ear".

Therefore, it is not accurate to transcribe two different phonemes with one character.
} 
Thus transliteration systems face a choice: they can either abandon the premise of strictly following the Kazakh orthography and adopt a "mixed" method mostly following the Cyrillic Script, but in certain cases (i.e. in case of $\langle u\rangle$ and $\langle y\rangle$ ) applying phonetic transcription, or they can stick to the strict Cyrillic-based transliteration. None of these alternatives is satisfying. Let us look at the latter scenario first: if we transliterate Kazakh examples, only one Latin character can correspond to each Cyrillic letter. For example, the Latin characters $\langle\mathrm{W}\rangle$ and $\langle\mathrm{i}\rangle$ could render the Cyrillic letters $\langle\mathrm{y}\rangle$ and $\langle\mathrm{u}\rangle$, respectively. In this case our transliteration looks like this:

(9) Sample of a transliteration system

$<\mathbf{y ы с}>\rightarrow<\mathbf{w i ̈ s}>$ 'palm; handful of something'

$<$ шолу $>\rightarrow<$ šolw $>$ 'review, survey'

$<$ уролог $>\rightarrow<$ wrolog $>$ 'urologist'

$<\mathbf{и е}>\rightarrow<\mathbf{i e}>$ 'master, owner'

$<$ иic $>\rightarrow<$ iiis $>$ 'smell'

$<$ иман $>\rightarrow<$ ïman $>$ 'faith, belief'

$<\mathbf{и з о г л о с > ~} \rightarrow<$ ïzoglos $>$ 'isogloss'

A possible problem with such a transliteration is that speakers of Kazakh might not even recognize the Kazakh words transliterated as $<$ wrolog $>$ or $<$ iiis $>$.

The former option seems slightly better, although it too has some undesirable consequences. According to the mixed approach the Kazakh Cyrillic letters $\langle u\rangle$ and $\langle y\rangle$ could be transcribed as $<\mathrm{iy} / \mathrm{ïy}>$ or $<\mathrm{i}>$ and $<\mathrm{w} / \mathrm{uw} / \mathrm{üw}>$ or $<\mathrm{u}>$, respectively. The transcription would be as follows:

(10) Sample of the mixed method

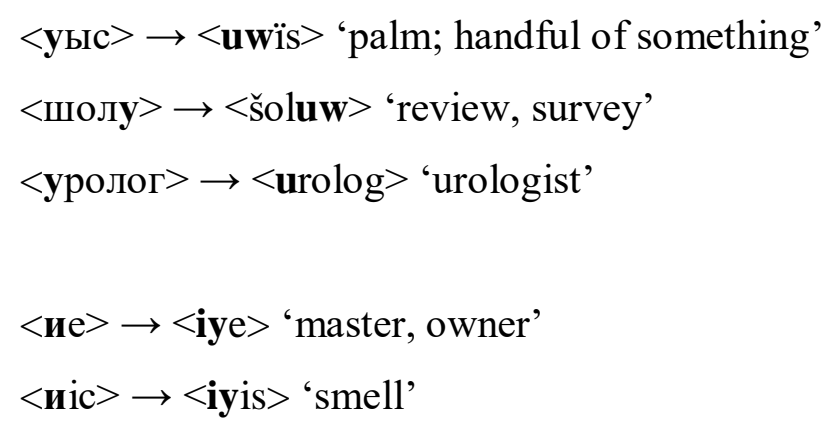


$<$ иман $>\rightarrow<$ iman $>$ 'faith, belief'

$<$ изоглос $>\rightarrow<$ izoglos $>$ 'isogloss'

The advantage of this approach is that it provides information about the right pronunciation. However this also results in inconsistencies: for the most part, this is a transliteration system, but in case of these two letters it follows the pronunciation. As a result, those (probably non-native) speakers who are not that familiar with the peculiarities of the Kazakh Cyrillic script won't be able to reconstruct it based on the Latin transliteration/transcription. This might cause problems if someone was going to look up a transcribed word in the Kazakh dictionary. (All Kazakh dictionaries I am aware of use the Cyrillic alphabet.) For example, the word $<$ iye $>$ might as easily have the Cyrillic form $<$ iйe $>$. Moreover, unless one is truly proficient in Kazakh, there is no way of knowing that the transcribed Kazakh verb <ilan-> 'to believe' is correctly spelled as <илан->, and not as $<$ ілан->.

It is noteworthy that the Cyrillic letters $\langle я\rangle$ and $\langle$ ю $\rangle$ come up in native Kazakh words too (besides Russian loanwords), in which case they are pronounced as /ya/ or /yä/ and /yu/ or /yü/, respectively. Neither transliterations or "mixed transliteration" systems indicate that the corresponding character in Cyrillic script of the transcribed /ya/, /yä/, /yu/ or /yü/ segments is only one letter, i.e. $<\boldsymbol{g}>$ or $<\mathrm{\wp}>$. This poses little problem if one is, to a certain extent, familiar with the Kazakh orthography, since /ya/ and /yä/ is never spelled $<$ йа $>$ or $<$ йə $>$ but $<$ я $>$.

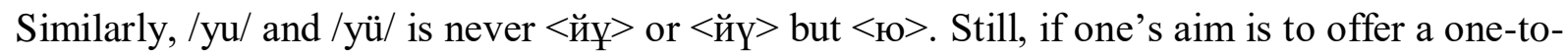
one equivalent to each Kazakh Cyrillic letter, this needs to be taken into consideration too.

As shown, the transliteration systems and "mixed" systems are not flawless, and for this reason I have decided not to transcribe or transliterate the numbered Kazakh sentences or examples in this work. I believe that, especially for potential Kazakh readers, this would help to read and process the Kazakh examples. Since this work is on the Kazakh language, this must be an important consideration.

However, in the English text, when I highlighted a certain part of a Kazakh example or when I gave a grammatical item, e.g. a suffix, I used the Latin script (as in (12)), because I did not want to disrupt the Latin script with Cyrillic examples.

I basically transliterated the Kazakh Cyrillic alphabet into Latin script, with two exceptions (in case of the Kazakh Cyrillic letters $\langle u\rangle$ and $\langle y\rangle$ ); thus this is a mixed system, too. However, I have tried to eliminate the shortcomings that other mixed systems have. I 
associate two Latin characters each to the Cyrillic letters $\langle\mathrm{u}\rangle$ and $\langle\mathrm{y}\rangle$, corresponding to the different phonemes. That is, the Kazakh Cyrillic letter $\langle u\rangle$ has two Latin equivalents: $\left\langle\mathrm{i}^{\mathrm{y}} / \mathrm{i}^{\mathrm{y}}\right\rangle$ in Turkic words and $<\mathrm{i}>$ in loanwords; moreover, the Latin letters $<\mathrm{W}>$ in Turkic words and $<\mathrm{u}>$ in loanwords correspond to the Cyrillic letter $<\mathrm{y}>$. Note the transcribed Latin $<\mathrm{u}>$ and $<i>$ characters cannot be taken to stand for the Cyrillic letters $\left\langle_{\sharp}\right\rangle$ and $\langle i\rangle$, since those have different Latin equivalents in my transliteration, namely $\langle\mathrm{u}\rangle$ and $\langle\mathrm{i}\rangle$. Moreover, the Cyrillic letters that stand for two sounds are represented by underbar letters in my transliteration, helping the reconstruction of the Cyrillic original.

(11) Sample from my proposed transliteration system

$<\mathbf{y ы с}>\rightarrow<$ wïs $>$ 'palm; handful of something'

$<$ шолу $>\rightarrow<$ šolw $>$ 'review, survey'

$<$ уролог $>\rightarrow<$ ųrolog $>$ 'urologist'

$<\mathbf{u}$ > $><\mathbf{i}^{\mathbf{y}}$ e $>$ 'master, owner'

$<$ uic $>\rightarrow<\mathbf{i}^{\mathbf{y}}$ is $>$ 'smell'

$<$ иман $>\rightarrow<$ ịman $>$ 'faith, belief'

$<\mathbf{и з о г л о с > ~} \rightarrow<$ įzoglos $>$ 'isogloss'

(12) Proposed transliteration of Kazakh Cyrillic characters

\begin{tabular}{|c|c|}
\hline $\begin{array}{l}\text { Letters in the Kazakh Cyrillic } \\
\text { alphabet }\end{array}$ & Proposed transcription \\
\hline $\mathrm{A} \mathrm{a}$ & $\mathrm{A} \mathrm{a}$ \\
\hline Ә ә & $\ddot{\mathrm{A}} \mathrm{ä}$ \\
\hline Б б & B b \\
\hline В в & $\mathrm{V} v$ \\
\hline$\Gamma \Gamma$ & Gg \\
\hline$F_{F}$ & $\dot{\mathrm{G}} \dot{\mathrm{g}}$ \\
\hline Д д & $\mathrm{Dd}$ \\
\hline $\mathrm{E}$ e & $\mathrm{E} \mathrm{e}$ \\
\hline$\ddot{\mathrm{e}}$ & yo \\
\hline Ж ж & Ž $\check{Z}$ \\
\hline 33 & $\mathrm{Zz}$ \\
\hline
\end{tabular}




\begin{tabular}{|c|c|}
\hline И и & $\mathrm{I}^{\mathrm{y}} / \ddot{I}^{\mathrm{y}} \mathrm{i}^{\mathrm{y} / \mathrm{i}^{\mathrm{y}}} / / \mathrm{I} \mathrm{i}$ \\
\hline Й й & $\mathrm{Yy}$ \\
\hline К к & $\mathrm{K} \mathrm{k}$ \\
\hline Қ қ & $\mathrm{Qq}$ \\
\hline Л л & $\mathrm{L} 1$ \\
\hline M M & $\mathrm{M} \mathrm{m}$ \\
\hline $\mathrm{H} \mathrm{H}$ & $\mathrm{Nn}$ \\
\hline ң & $y$ \\
\hline $\mathrm{Oo}$ & O o \\
\hline$\theta \theta$ & Ö ̈̈ \\
\hline П п & $\mathrm{Pp}$ \\
\hline $\mathrm{Pp}$ & $\mathrm{R} \mathrm{r}$ \\
\hline $\mathrm{Cc}$ & $\mathrm{S} \mathrm{s}$ \\
\hline $\mathrm{T} \mathrm{T}$ & $\mathrm{Tt}$ \\
\hline $\mathrm{yy}$ & $\mathrm{Ww} / / \mathrm{U} \mathrm{u}$ \\
\hline$¥_{¥}$ & $\mathrm{Uu}$ \\
\hline $\mathrm{Y}_{\mathrm{Y}}$ & $\ddot{U} \ddot{\mathrm{u}}$ \\
\hline$\Phi \phi$ & Ff \\
\hline $\mathrm{Xx}$ & $\mathrm{X} \chi$ \\
\hline $\mathrm{h} \mathrm{h}$ & $\mathrm{Hh}$ \\
\hline Ц ц & $\mathrm{Cc}$ \\
\hline Ч ч & $\check{C \check{C} \check{c}}$ \\
\hline Ш ш & $\overline{\mathrm{S}} \check{\mathrm{s}}$ \\
\hline Щ щ & $\underline{\text { Šč }} \underline{\underline{s ̌ c}}$ \\
\hline $\mathrm{b}$ & $"$ \\
\hline Ы ы & Ï̈̈̈ \\
\hline I i & I i \\
\hline b & , \\
\hline Э э & $\dot{\mathrm{E}} \dot{\mathrm{e}}$ \\
\hline Ю ю & $\underline{\mathrm{Yu} / Y \ddot{u} \mathrm{yu} / \mathrm{yü}}$ \\
\hline Я я & Ya/Yä ya/yä \\
\hline
\end{tabular}




\section{Appendix}

\section{Questionnaire 1}

The grammaticality judgements in Questionnaire 1 come from eight Kazakh native speakers who all live in Taraz (Žambïl Eyaleti), in South Kazakhstan. Most of them were either students or teachers at Тараз Мемлекеттік Педагогикалық Институты (Taraz National Pedagogical Institute); I would like to express my gratitude to them for taking the time to answer my questions. Special thanks goes to Анар Абуталиева for her incredibly useful comments and answers. I acquired these judgements during my third field research in Kazakhstan in December 2014.

The questionnaire given to the native speakers contained 59 sentences, which were in randomized order, and the native speakers were instructed to mark the incorrect sentences with a minus, the correct sentences with a plus, and if they are uncertain, indicate it with a question mark. (The original questionnaire is also attached to this work; see "Original Questionnaire 1".)

The sentences below are ordered in line with the analysis I follow in Chapter 2 (and to some extent in Chapter 3). Sentences (1)-(31) are concerned with the functional categories $-y / A$ and -(I)p can embed, sentences (32)-(50) deal with the order of high light verbs (see the relevant sections in Chapter 2), and negation with these high verbs. Note that below I also give the nine sentences which turned out to be infelicitous (for various reasons), these are not used in any way in this work.

The numbers in bold following the Kazakh sentences indicate how many native speakers marked the sentence as "correct" out of the total eight speakers. (For example, " $8 / 6$ " means that out of eight people six thought that the sentence was "correct".) The abbreviation QM stands for "question mark" (i.e. the speaker was uncertain about their judgement), and NA is "no answer" (when the speaker did not write anything to a sentence).

The sentences are evaluated according to the following scale:

1-3 = not grammatical (marked with *)

4-5 = undecided (marked with ?)

6-8 = grammatical (no marking). 
That is, if three or less speakers accepted the sentence, I consider the sentence ungrammatical, if six to eight people accepted it, I take the sentence to be grammatical. If four or five speakers accepted the sentence, I mark it with a question mark, and consider it undecided.

(1) Ол менің құшав-ылма күл-е кір-ді. 8/6

(s)he I.GEN lap-POSS.SG1.DAT smile-CV go.in-PAST.3

'(S)he sat on my lap smiling.'

(2) Ол менің құшаz-ыма күл-іп кір-ді. 8/6 (1 QM)

(s)he I.GEN lap-POSS.SG1.DAT smile-CV go.in-PAST.3

'(S)he sat on my lap smiling.'

(3) *Ол менің құшав-ылма күл-іп кет-е кір-ді. 8/3

(s)he I.GEN lap-POSS.SG1.DAT smile-IP LV.C-CV go.in-PAST.3

Intended: '(S)he sat on my lap smiling.'

(4) * Ол менің құшад-ыма күл-іп кет-іп кір-ді. 8/0

(s)he I.GEN lap-POSS.SG1.DAT smile-IP LV.C-CV go.in-PAST.3

Intended: '(S)he sat on my lap smiling.'

(5) Гүл-дер-ге құмарт-а қ̧ара-ды-м. 8/8

flower-PL-DAT yearn-CV look-PAST-SG1

'I looked at the flowers yearning'

(6) Гүл-дер-ге құмарт-ыл қ̧ара-дыл-м. 8/7

flower-PL-DAT yearn-CV look-PAST-SG1

'I looked at the flowers yearning'

(7) ${ }^{*} Г$ Гл-дер-ге құмарт-ыл жүр-е қзара-дыл-м. 8/1 (1 QM)

flower-PL-DAT yearn-IP LV.CONT-CV look-PAST-SG1

Intended: 'I looked at the flowers yearning' 
(8) Сыныптас-тар, көц̧іл қ̧оя тыңңда-йық!! 8/6

classmate-PL heart put.CV listen-OPT.PL1

'Classmates, let's listen carefully.'

(9) Сыныıптас-тар, көң̧іл қ̧ой-ыın тыңџда-йыıқ! 8/8

classmate-PL heart put-CV listen-OPT.PL1

'Classmates, let's listen carefully.'

(10) Қуан-а істе-иттін жұмыс-ы бар. 8/6

enjoy-CV do-NF work-POSS.3 exist

'(S)he has a job that she enjoys doing.'

(11) Қуан-ып істе-йтін жұмыс-ы бар. 8/8

enjoy-CV do-NF work-POSS.3 exist

'(S)he has a job that she enjoys doing.'

(12) *Қуан-ып кет-е істе-йтін жұмыс-ы бар. 8/1 (1 QM)

enjoy-IP LV.C-CV do-NF work-POSS.3 exist

Intended: '(S)he has a job that she enjoys doing.'

(13) Олар бір-біріне күлімде-й қ̧ара-дыл. 8/8

they each.other.POSS.3.DAT smile-CV look-PAST.3

'They looked at each other smilingly.'

(14) Олар бір-біріне күлімде-n қ̧ара-ды. 8/8

they each.other.POSS.3.DAT smile-CV look-PAST.3

'They looked at each other smilingly.' 
(15) ? Олар бір-біріне күлімде-п отыр-а қ̧ара-дыл. 8/4 (1 NA)

they each.other.POSS.3.DAT smile-IP LV.CONT-CV look-PAST.3

'They looked at each other smilingly.'

(16) *Олар бір-біріне күлімде-п кет-е ққара-ды. 8/1

they each.other.POSS.3.DAT smile-IP LV.C-CV look-PAST.3

'They looked at each other smilingly.'

(17) Дала-ва жүгір-е шық-ты. 8/7 (1 QM)

outside-DAT run-CV go.out-PAST.3

'He went out running.'

(18) Дала-ва жүгір-іп шық-ты. 8/8

outside-DAT run-CV go.out-PAST.3

'He went out running.'

(19) Дала-ва жүгір-е-жүгір-е шық-тыл. 8/7 (1 QM)

outside-DAT run-CV run-CV go.out-PAST.3

'He went out running.'

(20) *Дала-ва жүгір-іп жүр-е шық-тыл. 8/0

outside-DAT run-IP LV.CONT-CV go.out-PAST.3

Intended: 'He went out running.'

(21) ? Мола-ва бар-ыл, Құран-ды окы-ван-да, бір көр-дің тесіг-інен бір шал арбаңда-й шыз-ыл кел-дi. 8/4 (1 QM)

mullah-DAT go-CV Koran-ACC read-NF-LOC a tomb-GEN entrance-POSS.3.ABL a old.man tatterCV go.out.IP come-PAST.3

'When (s)he went to the mullah and read the Koran, an old man came out from the entrance of a tomb tattering.' 
(22) Мола-ва барып, Құранды окыванда, бір көрдің тесігінен бір шал арбаңуап шызып келді. 8/7

mullah-DAT go-CV Koran-ACC read-NF-LOC a tomb-GEN entrance-POSS.3.ABL a old.man tatterCV go.out.IP come-PAST.3

'When (s)he went to the mullah and read the Koran, an old man came out from the entrance of a tomb tattering.'

(23) *Мола-ва бар-ьın, Құран-ды окы-ван-да, бір көр-дің тесіг-інен бір шал арбаңда-n жүр-е шыз-ыли кел-ді. 8/2 (3 QM)

mullah-DAT go-CV Koran-ACC read-NF-LOC a tomb-GEN entrance-POSS.3.ABL a old.man tatterIP LV.CONT-CV go.out.IP come-PAST.3

Intended: 'When (s)he went to the mullah and read the Koran, an old man came out from the entrance of a tomb tattering.'

(24) ? Мола-ва бар-ыл, Құран-ды окы-ган-да, бір көр-дің тесіг-інен бір шал арбаңда-п жүр-іп шыз-bln кел-ді. 8/4

mullah-DAT go-CV Koran-ACC read-NF-LOC a tomb-GEN entrance-POSS.3.ABL a old.man tatterIP LV.CONT-CV go.out.IP come-PAST.3

'When (s)he went to the mullah and read the Koran, an old man came out from the entrance of a tomb tattering.'

(25) Біз кел-е, самаурын қ̧ой-ылл-ды. 8/6 (1 QM)

we come-CV samovar put-PASS-PAST.3

'The moment we arrived, the samovar was put (on the table),'

(26) *Біз кел-іп қ̧ал-а, самаурынн қ̧ой-ьлл-дыл. 8/1

we come-IP LV.C-CV samovar put-PASS-PAST.3

Intended: 'When we arrived, the samovar was put (on the table).'

(27) Біз кел-е сала, самаурын қ̧ой-ылл-ды. 8/7

we come-COMPL.CV samovar put-PASS-PAST.3

'The moment we arrived, the samovar was put (on the table).' 
(28) *Біз аудан орталыв-ынан шығ-а, алд-ылмызз-дан колхоз бастыз-ы жолық-ты. 8/2 (1 QM)

we district certre-CM.ABL leave-CV front-POSS.PL1-ABL kolkhoz leader-CM meet-PAST.3

Intended: 'The moment we left the district centre, the kolkhoz manager happened to be in front of us.'

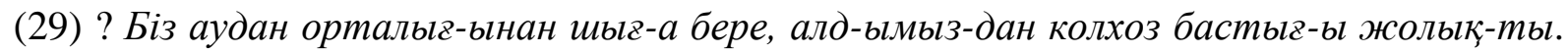

$8 / 5$

we district certre-CM.ABL leave-COMPL.CV front-POSS.PL1-ABL kolkhoz leader-CM meetPAST. 3

Intended: 'The moment we left the district centre, the kolkhoz manager happened to be in front of us.'

(30) *Біз аудан ортальв-ьнан шы-zып қ̧ал-а, алд-ылмыз-дан колхоз бастыз-ы жольқmbl. 8/0

we district certre-CM.ABL leave-IP-LV.C-CV front-POSS.PL1-ABL kolkhoz leader-CM meetPAST. 3

Intended: 'The moment we left the district centre, the kolkhoz manager happened to be in front of us.'

(31) Біз аудан ортальв-ынан шыз-а сала, алд-ылыьз-дан колхоз бастыв-ы жольқ-тыл.

\section{8/6 (1 QM)}

we district certre-CM.ABL leave-COMPL.CV front-POSS.PL1-ABL kolkhoz leader-CM meetPAST.3

'The moment we left the district centre, the kolkhoz manager happened to be in front of us.'

\section{Order of high ligh verbs}

(32) ? Газет әкел-іп бер-іп отьр-ван. 8/4 (1 QM)

newspaper bring-IP LV.B-IP LV.CONT-PERF.3

'He was bringing the newspaper (to someone).' 
(33) * Газет әкел-іп жүр-іп бер-ген. 8/0

newspaper bring-IP LV.CONT-IP LV.B-PERF.3

Intended: 'He was bringing the newspaper (to someone).'

(34) Қаваз-ва жаз-ьип бер-іп кет-ті. 8/8

paper-DAT write-IP LV.B-IP LV.C-PAST.3

'(S)he wrote it down on the paper. (for someone)'

(35) * Қаваз-ва жаз-ыл кет-іп бер-ді. 8/0

paper-DAT write-IP LV.C-IP LV.B-PAST.3

Intended: '(S)he wrote it down on the paper. (for someone)'

(36) ? Біз-дің қ̧ызметкер-лер оны Қызылорда-да пойыз-дан түс-ір-іп ал-ылn қ̧ал-дыл. 8/5 we-GEN personnel-PL (s)he.ACC Qïzïlorda-LOC train-ABL get.off-CAUS-IP LV.B-IP LV.CPAST.3

'Our personnel forced him/her to get off the train in Kyzylorda.'

(37) *Біз-дің құызметкер-лер оны Қызылорда-да пойыз-дан түс-ір-іп қ̧ал-ыли ал-ды. 8/0 we-GEN personnel-PL (s)he.ACC Qïzïlorda-LOC train-ABL get.off-CAUS-IP LV.C-IP LV.BPAST.3

Intended: 'Our personnel forced him/her to get off the train in Kyzylorda.'

(38) Шарлиз Терон шаш-ын тықыьрла-п ал-bın таста-дыл. 8/7

Charlize Theron hair-POSS.3.ACC cut.sg.short-IP LV.B-IP LV.C-PAST.3

'Charlize Theron cut her hair short.'

(39) *Шарлиз Терон шаш-ын тықырла-п таста-n ал-ды. 8/0

Charlize Theron hair-POSS.3.ACC cut.sg.short-IP LV.C-IP LV.B-PAST.3

Intended: 'Charlize Theron cut her hair short.' 
(40) Барльққ нәрсе өзгер-іп кет-е қ̧ояды. 8/5 (1 QM, 1 NA)

every thing change-IP LV.C-A LV.M.PRES.3

'Everything has changed quickly.'

(41) *Барльққ нарсе өзгер-е қ̧ой-ыли кет-еді. 8/0

every thing change-A LV.M-IP LV.C-PRES.3

Intended: 'Everything has changed quickly.'

(42) Қатар-дан шыъ-ыın қ̧ал-ыı жат-қ̧ан спортсмен-дер да жетерлік. 8/6 (1 QM) line-ABL leave-IP LV.C-IP LV.CONT-NF athlete-PL too sufficient

'The athletes who don't excel are sufficient.'

(43) *Біз сол кітапхана-дан қ̧олжазба-лар көшір-мей ал-ды-қ̧. 8/0

we that library-ABL manuscript-PL copy-MAY LV.B-NEG-PAST-PL1

Intended: 'We did not copy manuscripts from that library.'

(44) *Патша бұл іс-ті шеш-пей бер-ді. 8/0 (1 QM)

sultan this matter-ACC solve-MAY LV.B-PAST.3

'The sultan solved this issue.'

(45) Өмірбек Бек-ті таныл-май қ̧ал-ды. 8/8

Ömirbek Bek-ACC recognize-MAY LV.C-PAST.3

'Ömirbek did not recognize Bek.'

(46) ? Олар дым бер-мей жібер-ді. 8/5 (1 QM)

these voice give-MAY LV.C-PAST.3

'They didn't give a sound.'

(47) Төреші бұл гол-ды есеп-ке ал-май таста-ды. 8/6

referee this goal-ACC account-DAT take-MAY LV.C-PAST.3

'The referee didn't account this the goal.' 
(48) Қала биліг-і де қุара-п ққал-ма-ды. 8/6

city authority-CM too watch-IP LV.C-NEG-PAST.3

'The city government didn't just sit back.' (lit.: 'The city government didn't remain watching.')

(49) Құдай оны тавы да тірілт-іп жібер-ме-ді. 8/6

god (s)he.ACC again too revive-IP LV.C-NEG-PAST.3

'God didn't resurrect him/her one more time.'

(50) Есік-ті бекіт-іп таста-ма-цдар. 8/7

door-ACC close-IP LV.C-NEG-IMP.PL2

'Do not close the door!'

\section{Infelicitous sentences not used in the dissertation.}

*Менің жағдайым өзгеріп кеткелі қасыма келді. 8/2

*Әйелі түрмедегі күйеуін көріп қалғалы келіпті. 8/2 (1 QM)

*Әкелер бізге үй салып беріп кетпеді. 8/1

*Оқып алмақ керек. 8/2

? Жеңіс күнін миллиондаған сарбаз көре алмай кетті. 8/4

*Түйе бақырып тұра бастады. 8/3

*Сенің ағзаңда өзгерістер пайда бола бастап жатыр. 8/0

*Айгүл күліп кете салды. 8/2

*Жалғыз өзім жата зеріктім. 8/3 (1 NA) 


\section{Original Questionnaire 1}

Төмендегі сөйлемдердің барлығы бірбірінен басқаша, бірақ кейбір сөйлемдер арасында айырмашылық өте аз.

Дұрыс сөйлемдердің жанына +, ал қате сөйлемдердің жанына -, ал күмәнданған кезде ? белгілерін қоюларыңызды өтінемін.

1. Ол менің құшағыма күліп кете кірді.

2. Гүлдерге құмартып қарадым.

3. Барлық нәрсе өзгеріп кете қояды.

4. Қағазға жазып беріп кетті.

5. Куана істейтін жұмысы бар.

6. Олар бір-біріне күлімдеп қарады.

7. Далаға жүгіре-жүгіре шықты.

8. Біз сол кітапханадан қолжазбалар көшірмей алдық.

9. Қала билігі де қарап қалмады.

10. Әйелі түрмедегі күйеуін көріп қалғалы келіпті.

11. Ол менің құшағыма күліп кетіп кірді.

12. Қуанып кете істейтін жұмысы бар.

13. Біз келе, самаурын қойылды.

14. Молаға барып, Құранды окығанда, бір көрдің тесігінен бір шал арбаңдап жүре шығып келді.

15. Гүлдерге құмартып жүре қарадым.

16. Олар бір-біріне күлімдей қарады.

17. Далаға жүгіріп шықты.

18. Оқып алмақ керек.

19. Біз келіп қала, самаурын қойылды. 
20. Сыныптастар, көңіл қоя тыңдайық!

21. Біз аудан орталығынан шыға, алдымыздан колхоз бастығы жолықты.

22. Далаға жүгіре шықты.

23. Менің жағдайым өзгеріп кеткелі қасыма келді.

24. Молаға барып, Құранды окығанда, бір көрдің тесігінен бір шал арбаңдап шығып келді.

25. Айгүл күліп кете салды.

26. Олар дым бермей жіберді.

27. Есікті бекітіп тастамаңдар.

28. Куанып істейтін жұмысы бар.

29. Біз аудан орталығынан шыға бере, алдымыздан колхоз бастығы жолықты.

30. Жалғыз өзім жата зеріктім.

31. Шарлиз Терон шашын тықырлап алып тастады.

32. Жеңіс күнін миллиондаған сарбаз көре алмай кетті.

33. Ол менің құшағыма күле кірді.

34. Молаға барып, Құранды окығанда, бір көрдің тесігінен бір шал арбаңдай шығып келді.

35. Біз аудан орталығынан шығып қала, алдымыздан колхоз бастығы жолықты.

36. Гүлдерге құмарта қарадым.

37. Шарлиз Терон шашын тықырлап тастап алды.

38. Құдай оны тағы да тірілтіп жібермеді.

39. Олар бір-біріне күлімдеп отыра қарады.

40. Ол менің құшағыма күліп кірді.

41. Қатардан шығып қалып жатқан велошабандоздар да жетерлік.

42. Далаға жүгіріп жүре шықты. 
43. Сенің ағзаңда өзгерістер пайда бола бастап жатыр.

44. Төреші бұл голды есепке алмай тастады.

45. Газет әкеліп жүріп берген.

46. Түйе бақырып тұра бастады.

47. Біздің қызметкерлер оны Қызылордада пойыздан түсіріп алып қалды.

48. Патша бұл істі шешпей берді.

49. Қағазға жазып кетіп берді.

50. Біз келе сала, самаурын қойылды.

51. Әкелер бізге үй салып беріп кетпеді.

52. Барлық нәрсе өзгере қойып кетеді.

53. Сыныптастар, көңіл қойып тыңдайық!

54. Біз аудан орталығынан шыға сала, алдымыздан колхоз бастығы жолықты.

55. Молаға барып, Құранды окығанда, бір көрдің тесігінен бір шал арбаңдап жүріп шығып келді.

56. Олар бір-біріне күлімдеп кете қарады.

57. Біздің қызметкерлер оны Қызылордада пойыздан түсіріп қалып алды.

58. Өмірбек Бекті танымай қалды.

59. Газет әкеліп беріп отырған. 


\section{Questionnaire 2}

The grammaticality judgements in Questionnaire 2 come from a total of twenty native speakers of Kazakh. I had the questionnaire filled out by

- eight students from Almaty. All of them were the students of Әл-Фараби атындавь Қазақ ұлттық университеті (Al-Farabi Kazakh National University). Their answers are given with black-colour letters in the parentheses.

- nine native speakers who all live in Taraz (Žambïl Eyaleti), in South Kazakhstan. Most of them were either students or teachers at Тараз Мемлекеттік Педагогикалық Институты (Taraz National Pedagogical Institute). Their answers are given with red-colour letters in the parentheses.

- $\quad$ three students of Л. Н. Гумилев атындагы Еуразия ұлттық университеті (L.N. Gumilyov Eurasian National University) in Astana. Their answers are given with green-colour letters in the parentheses.

I would like to express my gratitude to all of them for taking the time to answer my questions. Special thanks goes again to Анар Абуталиева for her useful comments and answers.

The questionnaire given to the native speakers contained 97 sentences, which were in randomized order, and the native speakers were instructed to mark the incorrect sentences with a minus, the correct sentences with a plusö and if they are uncertain, indicate it with a question mark. (The original questionnaire is also attached to this work; see "Original Questionnaire 2".)

The order of the sentences below follows the logic of my analysis of them, as presented in Chapter 4.

The numbers in bold following the Kazakh sentences indicate how many native speakers marked the sentence as "correct" out of the total twenty speakers. (For example, "20/19" means that out of twenty people nineteen thought that the sentence was "correct".) The abbreviation QM stands for "question mark" (i.e. the speaker was uncertain about their judgement), and NA is "no answer" (when the speaker did not write anything to a sentence).

The sentences are evaluated according to the following scale:

1-5 = not grammatical (marked with *)

6-8 = rather ungrammatical (marked with ??)

9-11 = undecided (marked with ?) 
12-14 = rather grammatical (marked with \%)

15-20 = grammatical (no marking).

\section{Same subject $-w$-clauses in argument position}

(1а) [Сәнді киін-у]-ді өте жақ̆сы көр-е-мін. 20/19 [8/8; 9/8; 3/3]

[elegant dress-NNF]-ACC very good see-PRES-SG1

'I like dressing elegantly.'

(1b) *[Сәнді киін-у-ім]-ді өте жақсы көр-е-мін. 20/3 (1 QM) [8/0; 9/0 (1 QM); 3/3]

[elegant dress-NNF-POSS.SG1]-ACC very good see-PRES-SG1

Intended: 'I like dressing elegantly.'

(2а) Бүркіт [ақциа сана-у]-дыл біл-еді. 20/18 (1 QM) [8/7 (1 QM); 9/9; 3/2]

Bürkit [money count-NNF]-ACC know-PRES.3

'Bürkit knows how to count money.'

(2b) *Бүркіт [ақмша сана-у-ьын] біл-еді. 20/1 [8/1; 9/0; 3/0]

Bürkit [money count-NNF-POSS.3]ACC know-PRES.3

Intended: 'Bürkit knows how to count money.'

(3а) [Өмір-ге басқ̧а көзқ̧арас-пен қ̧ара-у]-ды үйрен-іп жүр-мін. 20/19 [8/7; 9/9; 3/3]

[life-DAT different view-INST look-NNF]-ACC learn-IP LV.CONT.PRES-SG1

'I'm learning to view the life from a different standpoint.'

(3b) ?? [Өмір-ге басқ̧а көзқ̧арас-пен қ̧ара-у-blм]-ды үйрен-іп жүр-мін. 20/7 [8/2; 9/2; 3/3] [life-DAT different view-INST look-NNF-POSS.SG1]-ACC learn-IP LV.CONT.PRES-SG1 Intended: 'I'm learning to view the life from a different standpoint.' 


\section{Different subject $-w$-clauses in argument position}

(4a) [Aйт-y-bıм] а рұқ̧сат ет-ің̧із-ші. 20/16 (1 NA) [8/5; 9/9; 3/2 (1 NA)]

[tell-NNF-POSS.SG1]DAT permit LV-IMP.FORML-POL

'Allow me to tell (it).'

(4b) *[Мен айт-y]-ва рұқ̧сат ет-ің̧із-щі. 20/1 [8/0; 9/1; 3/0]

[I tell-NNF]-DAT permit LV-IMP.FORML-POL

Intended: 'Allow me to tell (it).'

(5а) \% Ене-м [немере-сін қ̧ас-ына жібер-у-ім]-ді өтін-еді. 20/14 [8/5; 9/7; 3/2]

mother.in.law-POSS.SG1 [grand.child-POSS.3.ACC side-POSS.3.DAT send-NNF-POSS.SG1]-ACC request-PRES.3

'My mother-in-law requested that I send her grand child to her.'

(5b) *Ене-м [мен немере-сін қ̧ас-ына жібер-у]-ді өтін-еді. 20/4 [8/0; 9/2; 3/2]

mother.in.law-POSS.SG1 [I grand.child-POSS.3.ACC side-POSS.3.DAT send-NNF]-ACC requestPRES.3

Intended: 'My mother-in-law requested that I send her grand child to her.'

(6а) [Мейрамхана-ның жуырда аш-ылл-у-ы] күт-іл-уде. 20/19 [8/8; 9/8; 3/3]

[restaurant-GEN presently open-PASS-NNF-POSS.3] wait-PASS-FOC.PRES.3

'The restaurant is expected to be opened soon.'

(6b) *[Мейрамхана жуырда аш-ылл-y] күт-іл-уде. 20/0 [8/0; 9/0; 3/0]

[restaurant presently open-PASS-NNF] wait-PASS-FOC.PRES.3

Intended: 'The restaurant is expected to be opened soon.' 
(7а) Ал азан шақыьр-у арқыль сәби-ге ат ққою дәстүр-і [құазақ жер-іне ислам-ның кел-уi]-мен тызызз байланыстыл. 20/17 (3 QM) [8/8; 9/6 (3 QM); 3/3]

and azan call-NNF through child-DAT name put-NNF tradition-CM [Kazakh territory-CM.DAT Islam-GEN come-NNF-POSS.3]-INST closely be.connected

'And the tradition that naming a child (is made) by calling the azan is closely connected to the Islam's appearance on Kazakh territory.'

(7b) ? Ал азан шақыр-у арққыль сәби-ге ат қою дәстүр-і [қазақ жер-іне ислам кел-у]мен тызызз байланысты. 20/10 (1 QM) [8/3; 9/4 (1 QM); 3/3]

and azan call-NNF through child-DAT name put-NNF tradition-CM [Kazakh territory-CM.DAT Islam come-NNF]-INST closely be.connected

'And the tradition that naming a child (is made) by calling the azan is closely connected to the Islam's appearance on Kazakh territory.'

\section{Different subject $-w$-clauses in non-argument position}

(8а) ? [Оның тамақтан-y-bl] үшін дйел-і көмектес-еді. 20/10 (1 QM) [8/3; 9/7 (1 QM); $3 / 0]$

[he.GEN eat-NNF-POSS.3] for wife-POSS.3 help-PRES.3

'His wife help her, so that he could eat.'

(8b) ? / \% [Ол тамақ̧тан-y] үшін дйел-і көмектес-еді. 20/11 (1 QM) [8/4; 9/7; 3/0 (1 QM)]

[he eat-NNF] for wife-POSS.3 help-PRES.3

'His wife help her, so that he could eat.'

\footnotetext{
${ }^{153}$ As shown by the numbers, half of the native speakers accepted this sentence. According to my analysis this sentence should not be acceptable. I have only tentative explanations for the relatively high number of speakers who marked this example as correct: first of all, the superordinate predicate is not a verb, and it does not licence an accusative case. Also note that this example is fairly long, and I noticed that it is more difficult to detect "minor errors" in longer sentences.
} 
(9а) *Спорт киімі қолайлы, жеңіл және әдемі болумен бірге, оның үстіне дененің температурасын реттеп те отыра алатын болуға тиіс. 20/4 (5 QM; 1 NA) [8/2; 9/1 (5 $\mathrm{QM}) ; 3 / 1$ (1 NA)]

(9b) ?? Спорт киімінің қолайлы, жеңіл және әдемі болуымен бірге, оның үстіне дененің температурасын реттеп те отыра алатыны болуға тиіс. 20/6 (2 QM) [8/1; 9/4 (2 QM); 3/1]

(10а) \% [Суық түс-у]-мен бірге маусым-дық ауру-лар да пайда бол-ады. 20/12 (2 QM) [8/4; 9/6 (2 QM); 3/2]

[cold fall-NNF]-INST together season-ADJ illness-PL too (come.into.existence)-PRES.3

'Together with the setting in of the cold (weather), seasonal illnesses appear as well.'

(10b) ? [Суық түс-у-і]-мен бірге маусым-дық ауру-лар да пайда бол-ады. 20/9 (2 QM; 1 NA) [8/4 (1 NA); 9/4 (2 QM); 3/1]

[cold fall-NNF-POSS.3]-INST together season-ADJ illness-PL too (come.into.existence)-PRES.3 'Together with the setting in of the cold (weather), seasonal illnesses appear as well.'

(10с) [Суық-тың түс-у-і]-мен бірге маусым-дық ауру-лар да пайда бол-ады. 20/15 [8/5; $9 / 8 ; 3 / 2]$

[cold-GEN fall-NNF-POSS.3]-INST together season-ADJ illness-PL too (come.into.existence)PRES. 3

'Together with the setting in of the cold (weather), seasonal illnesses appear as well.'

\section{Same subject $-G A n,-y / A t I n$ and $-(A) r$-headed clauses in argument position}

(11а) [Тау-ва бар-ван]-ды, [коньки теп-кен]-ді жақссы көр-е-мін. 20/20 [8/8; 9/9; 3/3]

[mountain-DAT go-NF]-ACC [skate LV-NF]-ACC (like)-PRES-SG1

'I like going to the mountainside (and I like) skating.'

(11b) *[Тау-ва бар-ван-ылм]-ды,, [коньки теп-кен-ім]-ді жақсы көр-е-мін. 20/1 [8/0 9/1 3/0]

[mountain-DAT go-NF-POSS.SG1]-ACC [skate LV-NF-POSS.SG1]-ACC (like)-PRES-SG1

Intended: 'I like going to the mountainside (and I like) skating.' 
(11c) *[Тау-ва бар-ван-дық]-ты, [коньки тер-кен-дік]-ті жақсы көр-е-мін. 8/0 [mountain-DAT go-NF-LIq]-ACC [skate LV-NF-POSS.SG1]-ACC (like)-PRES-SG1

Intended: 'I like going to the mountainside (and I like) skating.'

(12а) Арыстан [басқару мен басты рөл-де жүр-ген]-ді ұнат-ады. 20/19 [8/7; 9/9; 3/3] leo [ruling INST leading role-LOC walk-NF]-ACC like-PRES.3

'Leo likes being in a leading role.'

(12b) ?? Арыстан [басқару мен басты рөл-де жүр-ген-ін] ұнат-ады. 20/6 (2 QM) [8/1; 9/3 (2 QM); 3/2]

leo [ruling INST leading role-LOC walk-NF-POSS.3]ACC like-PRES.3

Intended: 'Leo likes being in a leading role.'

\section{Different subject $-G A n,-y / A t I n$ and $-(A) r$-headed clauses in argument position}

(13а) [Қазір-гі күн-ге дейін әке-м тураль мәлімет-тер-дің халық-қ̧а жет-кен-ін]е куана-мын. 20/18 (1 QM) [8/7; 9/8 (1 QM); 3/3]

[now-ADJ day-DAT until father-POSS.SG1 about information-PL-GEN people-DAT reach-NFPOSS.3]DAT rejoice-PRES-SG1

'I am glad that information about my father has gotten to the people until this day.'

(13b) ? [Қазір-гі күн-ге дейін әке-м тураль мәлімет-тер халық-ққа жет-кен]-ге куан-амын. 20/9 (1 QM) [8/3; 9/4 (1 QM); 3/2]

[now-ADJ day-DAT until father-POSS.SG1 about information-PL people-DAT reach-NF]-DAT rejoice-PRES-SG1

'I am glad that information about my father has gotten to the people until this day.'

(14а) [Журнал-дың тавдыр-ы не бол-атын-ын] алда-вы уақыт көрсет-ер. 20/17 (1 QM) [8/6; 9/8 (1 QM);3/3]

[journal-GEN destiny-POSS.3 what be-NF-POSS.3]ACC front-ADJ time show-PROSP.3

'The time before us will show what the destiny of the journal is going to be.' 
(14b) *[Журнал тавдыр-ы не бол-атын]-ды алда-вы уақыт көрсет-ер. 20/2 [8/0; 9/1; $3 / 1]^{154}$

[journal destiny-POSS.3 what be-NF]-ACC front-ADJ time show-PROSP.3

Intended: 'The time before us will show what the destiny of the journal is going to be.'

(15а) Еркек-тер-ге [әйел-дің̧ иіссу шаш-қ̧ан-ы] ұна-й ма? 20/18 [8/6; 9/9; 3/3]

man-PL-DAT [woman-GEN perfume sprinkle-NF-POSS.3] like-PRES.3 Q

'Do men like that women use perfume?'

(15b) ? Еркек-тер-ге [әйел-дің иіссу шаш-қ̧ан-дыз-ыl] ұна-й ма? 20/10 (2 QM) [8/1; 9/6 (2 QM); 3/3]

man-PL-DAT [woman-GEN perfume sprinkle-NF-LIq-POSS.3] like-PRES.3 Q

'Do men like that women use perfume?'

(16а) Салтанат-ты қ̧ол қ̧ою рәсім-інен кейін [18 мамыр-да Күлтегін күн-і аталып өтетін-і] белгіле-н-ді. 20/17 [8/7; 9/7; 3/3]

parade-ACC (sign).NNF celebration-CM.ABL after [18 May-LOC Kültegin day-CM called passNF-POSS.3] announce-PASS-PAST.3

'After the celebration of the signing of the parade, it was announced that on $18^{\text {th }}$ May there will be (a day) called "Kül tegin Day".'

(16b) Салтанат-ты қ̧ол қ̧ою рәсім-інен кейін [18 мамыр-да Күлтегін күн-і аталып өтетін-діг-і] белгіле-н-ді. 20/14 (1 QM; 1 NA) [8/7; 9/6 (1 QM); 3/1 (1 NA)]

parade-ACC (sign).NNF celebration-CM.ABL after [18 May-LOC Kültegin day-CM called passNF-LIq-POSS.3] announce-PASS-PAST.3

'After the celebration of the signing of the parade, it was announced that on $18^{\text {th }}$ May there will be (a day) called "Kül tegin Day".'

(17а) Өмірбек [өткен апта-да Алматы-да бол-ван-ьлн] айт-ты. 20/18 [8/6; 9/9; 3/3]

Ömirbek [last week-LOC Almatï-LOC be-NF-POSS.3]ACC say-PAST.3

'Ömirbek said that he was in Almaty last week.'

\footnotetext{
${ }^{154}$ I did not use this example in my discussion about -y/AtIn-headed constructions because I made an unintended mistake preparing the questionnaire: the genitive is missing on the word žurnal 'destiny'; the correct version should be žųrnaldïy tagdirï 'the destiny of the journal'.
} 
(17b) Өмірбек [өткен апта Алматы-да бол-ван-дыз-ын] айт-ты. 20/15 (3 QM) [8/6 (1 $\mathrm{QM}) ;$ 9/6 (2 QM); 3/3]

Ömirbek [last week Almatï-LOC be-NF-POSS.3-LIq]ACC say-PAST.3

'Ömirbek said that he was in Almaty last week.'

(18а) [Жұмыс-ты мойында-ма-zан-ы]], [жұмыс-ты көңзілден-іп істе-ме-ген-і] іс-інен де көрін-іп тұр. 9/6 (1 QM) ${ }^{155}$

[work-ACC accept-NEG-NF-POSS.3] [work-ACC be.glad-CV do-NEG-NF-POSS.3] workPOSS.3.ABL too seem-IP LV.CONT.PRES.3

'(The fact that) (s)he does not take the work (well), that (s)he does not do his/her work with joy, is clear from his/her work as well.'

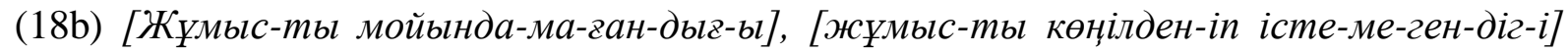
іс-інен де көрін-іп тұр. 9/7

[work-ACC accept-NEG-NF-LIq-POSS.3] [work-ACC be.glad-CV do-NEG-NF-LIq-POSS.3] workPOSS.3.ABL too seem-IP LV.CONT.PRES.3

'(The fact that) (s)he does not take the work (well), that (s)he does not do his/her work with joy, is clear from his/her work as well.'

(19а) Ең жақсы қ̧асиет-і - [ешкім-мен төбелес-іп, сөз-ге кел-ме-йтін-і] еді. 20/17 [8/7; $9 / 8 ; 3 / 2]$

SUPL good property-POSS.3 [nobody-INST fight-CV word-DAT come-NEG-NF-POSS.3] COP.PAST.3

'His/Her best property was that (s)he did not fight or argue with anyone.'

${ }^{155}$ In (18a) and (18b) I only give the results from Taraz, because there was a mistake in the Almaty and the

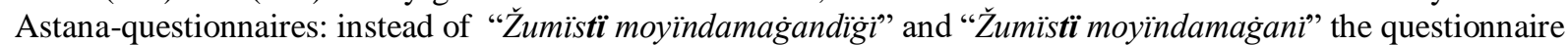

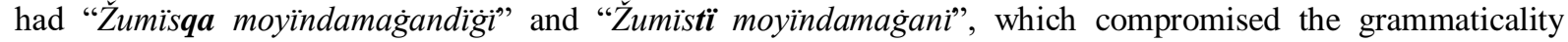
judgements. (The results from the Almaty and the Astana-questionnaires are the following: (18a): 8/1, 3/1; (18b): $8 / 0,3 / 1$. 
(19b) Ең жақ̆сы қ̧асиет-і - [ешкім-мен төбелес-іп, сөз-ге кел-ме-йтін-діг-i] еді. 20/16 [8/7; 9/9; 3/0]

SUPL good property-POSS.3 [nobody-INST fight-CV word-DAT come-NEG-NF-LIq-POSS.3] COP.PAST.3

'His/Her best property was that (s)he did not fight or argue with anyone.'

(20а) \% [Үй-дің ертеде сал-ын-ван-ын]а көз жеткіз-у де оңзай. 20/14 [8/6; 9/5; 3/3] [house-GEN long.time.ago build-PASS-NF-POSS.3]DAT eye deliver-NNF part easy

'It is also easy to prove that the house was built a long time ago.'

(20b) [Yй-дің ертеде сал-ын-ван-дыұ-ын]а көз жеткіз-у де оңай. 20/17 [8/6; 9/8; 3/3]

[house-GEN long.time.ago build-PASS-NF-LIq-POSS.3]DAT eye deliver-NNF part easy

'It is also easy to prove that the house was built a long time ago.'

(21а) ? [Оныңщ табыт ал-атын-ы]] күмәнсіз. 20/8 (7 QM) [8/4 (1 QM); 9/2 (5 QM); 3/2 (1 QM)]

[(s)he.GEN coffin take-NF-POSS.3] certain

It is certain that (s)he will buy a coffin.

(21b) ? [Оның табыт ал-атын-дыз-ыl] күмәнсіз. 20/7 (4 QM; 2NA) [8/3 (2 NA); 9/5 (2 QM); 3/0 (2 QM)]

[(s)he.GEN coffin take-NF-LIq-POSS.3] certain

It is certain that (s)he will buy a coffin.

(22a) (\%) Бастыз-blмblз үнсіз қ̧ал-ды - онысы [Муся-ның айт-қ̧ан-ына амалсыз көн-гені]нің белгі-сі. 20/14 (1 QM) [8/4; 9/8 (1 QM); 3/2]

boss-POSS.PL1 without.sound stay-PAST.3 him.doing.that [Musya-GEN say-NF-POSS.3.DAT obligatory accept-NF-POSS.3]GEN sign-POSS.3

'Our boss remained quiet, which was the sign of agreeing to what Musya said.' 
(22b) (\%) Бастыз-blмыз үнсіз қ̧ал-ды - онысыс [Муся-ның айт-қ̧ан-ына амалсыз көн-гендіг-і]нің белгі-сі. 20/14 (1 NA) [8/3 (1 NA); 9/8; 3/3]

boss-POSS.PL1 without.sound stay-PAST.3 him.doing.that [Musya-GEN say-NF-POSS.3.DAT obligatory accept-NF-LIq-POSS.3] GEN sign-POSS.3

'Our boss remained quiet, which was the sign of agreeing to what Musya said.'

\section{VI. -GAn-headed complement clauses of semantic cases and postpositions}

\section{VI.1. Ablative (-DAn)}

(23a) ? / \% [Шеше-сі ерте қ̧айтыс бол-ван-дық-тан, менің ана-м Әлиша-ны да Тыныббала апа бав-bın-қ̧аz-bın өсір-ген. 20/11 (1 QM) [8/6; 9/3 (1 QM); 3/2]

[mother-POSs.3 early (pass.away)-NF-LIq]-ABL I.GEN mother-POSs.1 Äliša-ACC too Tïnïbala aunt care-CV beat-CV bring.up-PERF. 3

'Because her mother passed away early, Aunt Tynybala raised my mother Alisha too beating and taking care (of her).'

(23b) ?? [Шеше-сі-нің ерте қ̧айтыс бол-ван-дыъ-bl]нан, менің ана-м Әлишань да Тыныбала апа бав-bın-қ̧аz-ыın өсір-ген. 20/7 (1 QM; 1 NA) [8/4; 9/3 (1 QM); 3/0 (1 NA)] [mother-POSS.3-GEN early (pass.away)-NF-LIq-POSS.3]ABL I.GEN mother-POSs.1 Äliša-ACC too Tïnïbala aunt care-CV beat-CV bring.up-PERF. 3

'Because her mother passed away early, Aunt Tynybala raised my mother Alisha too beating and taking care (of her).'

(24а) [Ата-ана-м филолог бол-ган-дық]-тан бала кез-ден тіл-ге икем-ім жақсы бол-ды. 20/15 (1 NA) [8/6; 9/8; 3/1]

[father mother-POSS.1 philologist be-NF-LIq]-ABL child time-ABL language-DAT ability-POSs.1 good be-PAST. 3

'Because my parents are philologists, I have had a talent for languages since my childhood.' 
(24b) ?? [Ата-ана-м филолог бол-zан-дыз-ыl]нан бала кез-ден тіл-ге икем-ім жақсы болdbl. 20/8 [8/2; 9/6; 3/0]

[father mother-POSS.1 philologist be-NF-LIq-POSS.3]ABL child time-ABL language-DAT abilityPOSS.1 good be-PAST.3

'Because my parents are philologists, I have had a talent for languages since my childhood.'

\section{VI.2. Locative (-DA)}

(25а) [Мен даң̧zыра соқ--қ̧ан]-да, қырық есік-ті бекіт-іп таста-ң̧дар. 20/18 [8/6; 9/9; 3/3]

[I kind.of.drum hit-NF]-LOC forty door-ACC close-IP LV.C-IMP.PL2

'When I hit the drum, close the forty doors.'

(25b) [Мен даңъдыра соқ--қан-ыlм]-да, қыырық есік-ті бекіт-іп таста-ц̧дар. 20/15 (1 QM) [8/7; 9/5 (1 QM); 3/3]

[I kind.of.drum hit-NF-POSS.1]-LOC forty door-ACC close-IP LV.C-IMP.PL2

'When I hit the drum, close the forty doors.'

(25c) ?? / ? [Менің даң̧ъыра соқ-қ̧ан-ыл]-да, қырық есік-ті бекіт-іп таста-ц̧дар. 20/8 (1 QM) [8/4; 9/2 (1 QM); 3/2]

[I.GEN kind.of.drum hit-NF-POSS.1]-LOC forty door-ACC close-IP LV.C-IMP.PL2

'When I hit the drum, close the forty doors.'

(25d) * / ?? [Даңъвыра соқ̧-қ̧ан-дыв-ымм]-да, қырық есік-ті бекіт-іп таста-ц̧дар. 20/5 (1 QM) [8/0; 9/3;3/2 (1 QM)]

[kind.of.drum hit-NF-LIq-POSS.1]-LOC forty door-ACC close-IP LV.C-IMP.PL2

'When I hit the drum, close the forty doors.' 


\section{VI.3. Instrumental (-Men)}

(26а) [Әке-м-нің негіз-гі тамыр-ыл ақтөбе-лік бол-ван-ыл]-мен, ту-ван жер-і Қарақ̧алпақ̧стан. 20/17 (1 QM) [8/7; 9/7 (1 QM); 3/3]

[father-POSS.SG1-GEN basis-ADJ origin-POSS.3 Aqtöbe-ADJ be-NF-POSS.3]-INST be.born-NF place-POSS.3 Qaraqalpaqstan

'Although my father is essentially from Aktöbe, the place where he was born is Karakalpakstan.'

(26b) ?? [Әке-м-нің негіз-гі тамыр-ы ақтөбе-лік бол-ван-дыз-ьl]-мен, тудан жері Қарақ̧алпақ̧стан. 20/7 (1 QM) [8/1; 9/4; 3/2 (1 QM)]

[father-POSS.SG1-GEN basis-ADJ origin-POSS.3 Aqtöbe-ADJ be-NF-LIq-POSS.3]-INST be.born-NF place-POSS.3 Qaraqalpaqstan

'Although my father is essentially from Aktöbe, the place where he was born is Karakalpakstan.'

(26c) ? / \% [Әке-м негіз-гі тамыр-ы ақтөбе-лік бол-ган]-мен, туган жері Қарақ̆алпақстан. 20/11 (1 QM) [8/2 (1 QM); 9/7; 3/2]

[father-POSS.SG1 basis-ADJ origin-POSS.3 Aqtöbe-ADJ be-NF]-INST be.born-NF place-POSS.3 Qaraqalpaqstan

'Although my father is essentially from Aktöbe, the place where he was born is Karakalpakstan.'

\section{VI.4. The semantic case -DAy}

(27а) [Алла елші-сі-нің, істе-ген-ін]-дей істе. 20/15 (3 QM; 1 NA) [8/6 (1 NA); 9/6 (3 $\mathrm{QM}) ; 3 / 3]$

[Allah delegate-CM-GEN do-NF-POSS.3]-DAy do.IMP.SG2

'Act as Allah's delegate does.'

(27b) \% [Алла елші-сі-нің істе-ген-діг-ін]-дей істе. 20/12 (1 QM) [8/3; 9/7; 3/2 (1 QM)]

[Allah delegate-CM-GEN do-NF-LIq-POSS.3]-DAy do.IMP.SG2

'Act as Allah's delegate does.' 
(27c) [Алла елші-сі істе-ген]-дей істе. 20/15 [8/6; 9/8; 3/1]

[Allah delegate-CM do-NF]-DAy do.IMP.SG2

'Act as Allah's delegate does.'

(28а) ? / \% [Хабарлама-да атап көрсет-іл-ген-ін]-дей, Юрий Берг шешім-ге қүол қүой-zан. 20/10 (2 QM; 1 NA) [8/5; 9/2 (2 QM; 1 NA); 3/3]

[aricle-LOC (emphasize)-PASS-NF-POSS.3]-DAy Jurij Berg decision-DAT (sign)-PERF.3

'As it was emphasized in the article, Jurij Berg signed the decision.'

(28b) ? [Хабарлама-да атап көрсет-іл-ген-діг-ін]-дей, Юрий Берг шешім-ге қ̧ол қ̧ой-ван. 20/11 [8/4; 9/4; 3/3]

[aricle-LOC (emphasize)-PASS-NF-LIq-POSS.3]-DAy Jurij Berg decision-DAT (sign)-PERF.3

'As it was emphasized in the article, Jurij Berg signed the decision.'

\section{VI.5. The postposition (-ABL) soy}

(29a) [Ок̧ас кел-ген] соң клуб іс-і жандан-ды. 20/14 (2 QM; 1 NA) [8/6; 9/6 (2 QM; 1NA); $3 / 2]$

[Oqas come-NF] after club business-CM liven.up-PAST.3

'After Okas arrived, the business livened up.'

(29b) [Оқ̧ас кел-ген]-нен соң клуб іс-і жандан-ды. 20/16 (1 QM) [8/4 (1 QM); 9/9; 3/3]

[Oqas come-NF]-ABL after club business-CM liven.up-PAST.3

'After Okas arrived, the business livened up.'

(29c) *[Оқас-тың кел-ген-і] соң клуб іс-і жандан-дыл. 20/0 [8/0; 9/0; 3/0]

[Oqas-GEN come-NF-POSS.3] after club business-CM liven.up-PAST.3

Intended: 'After Okas arrived, the business livened up.' 
(29d) *[Ок̧ас-тың кел-ген-і]нен соң клуб іс-і жандан-ды. 20/3 (1 QM) [8/2 (1 QM); 9/1; $3 / 0]$

[Oqas-GEN come-NF-POSS.3]ABL after club business-CM liven.up-PAST.3

Intended: 'After Okas arrived, the business livened up.'

(29e) *[Оқ̧ас-тыңц кел-ген-діг-і] соң клуб іс-і жандан-ды. 20/1 [8/0; 9/1; 3/0]

[Oqas-GEN come-NF-LIq-POSS.3] after club business-CM liven.up-PAST.3

Intended: 'After Okas arrived, the business livened up.'

(29f) *[Ок̧ас-тың кел-ген-діг-і]нен соң клуб іс-і жандан-ды. 20/3 [8/2; 9/1; 3/0]

[Oqas-GEN come-NF-LIq-POSS.3]ABL after club business-CM liven.up-PAST.3

Intended: 'After Okas arrived, the business livened up.'

\section{VI.6. The postposition -DAT šeyin}

(30а) \% [Ғайша кел-ген]-ге шейін, біз-ді Садық мұвалім оқыьт-ты. 20/13 (1 NA) [8/4 (1 NA); 9/7;3/2]

[Ġayša come-NF]-DAT until we-ACC Sadiq teacher teach-PAST.3

'Until 'Aysha didn't arrive, teacher Sadyk had taught us.'

(30b) ? [Ғайша-ның кел-ген-ін]е шейін, біз-ді Садық мұвалім оқыьт-ты. 20/10 (2 QM) [8/3; 9/4 (2 QM);3/3]

[Ġayša-GEN come-NF-POSS.3]DAT until we-ACC Sadïq teacher teach-PAST.3

'Until 'Aysha didn't arrive, teacher Sadyk had taught us.'

(30с) *[Ғайша-ның кел-ген-діг-ін]е шейін, біз-ді Садық мұвалім оқыт-тыл. 20/3 [8/0; 9/1; 3/2]

[Ġayša-GEN come-NF-LIq-POSS.3]DAT until we-ACC Sadïq teacher teach-PAST.3

Intended: 'Until 'Aysha didn't arrive, teacher Sadyk had taught us.' 


\section{VI.7. The postposition sayïn}

(31а) [Әшім баяндама жаса-ван] сайьн, жұрт көп кел-еді. 20/19 [8/8; 9/8; 3/3]

[Äšim lecture make-NF] every people many come-PRES.3

'Every time Ashim gives a lecture, many people come.'

(31b) *[Әшім-нің баяндама жаса-ван-ыl] сайын, жұрт көп кел-еді. 20/2 (1 QM) [8/0; 9/0 (1 QM); 3/2]

[Äšim-GEN lecture make-NF-POSS.3] every people many come-PRES.3

Intended: 'Every time Ashim gives a lecture, many people come.'

(31с) *[Әшім баяндама жаса-ван-ьл] сайын, жұрт көп кел-еді. 20/3 [8/0; 9/1; 3/2]

[Äšim lecture make-NF-POSS.3] every people many come-PRES.3

Intended: 'Every time Ashim gives a lecture, many people come.'

(31d) *[Әшім-нің баяндама жаса-ван-дыз-ы]] сайын, жұрт көп кел-еді. 20/2 [8/0; 9/1; $3 / 1]$

[Äšim-GEN lecture make-NF-LIq-POSS.3] every people many come-PRES.3

Intended: 'Every time Ashim gives a lecture, many people come.'

\section{VI.8. The postposition twrali}

(32а) Алвашқы кеңес кез-ін-де дәрігер [дйел-дің жалпы денсаульв-ы-ның к̧андай болван-ыl] туральь анықта-йды. 20/14 (1 QM) [8/4 (1 QM); 9/9; 3/1]

earlier Soviet time-CM-LOC doctor [woman-GEN general health-POSS.3.GEN how be-NF-POSS.3] about give.information-PRES.3

'Earlier in the Soviet times the doctor gave information about how the women's general health was.' 


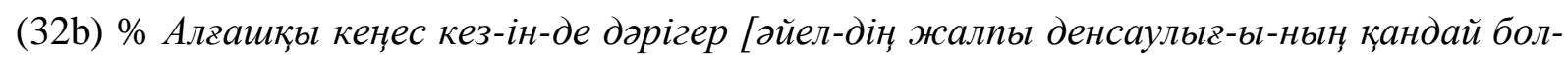
zан-дыц-bl] туральы анықта-йды. 20/12 (1 QM) [8/2; 9/7 (1 QM); 3/3]

earlier Soviet time-CM-LOC doctor [woman-GEN general health-POSS.3.GEN how be-NF-LIqPOSS.3] about give.information-PRES.3

'Earlier in the Soviet times the doctor gave information about how the women's general health was.'

(32c) ?? Алzашқ̧ы кеңес кез-ін-де дәрігер [әйел-дің жалпы денсаулыз-ы қ̧андай бол-ван] туральы анықта-йды. 20/7 (1 QM) [8/2; 9/5; 3/0 (1 QM)]

earlier Soviet time-CM-LOC doctor [woman-GEN general health-POSS.3.GEN how be-NF] about give.information-PRES.3

'Earlier in the Soviet times the doctor gave information about how the women's general health was.'

(33а) Путин-нің, баспасөз хатшы-сы [президент-тіңу неке-ге тұр-zан-ыл] туралы хабарды жоқққа шызар-ды. 20/19 [8/7; 9/9; 3/3]

Putin-GEN press secretary-POSS-3 [president-GEN marriage-DAT stand-NF-POSS.3] about newsACC (refute)-PAST.3

'Putin's spokesman refuted the news about the president having gotten married.'

(33b) Путин-нің баспасөз хатшы-сы [президент-тің неке-ге тұр-ван-дыз-ьы] туральы хабар-ды жоққа шызар-дыл. 20/20 [8/8; 9/9; 3/3]

Putin-GEN press secretary-POSS-3 [president-GEN marriage-DAT stand-NF-LIq-POSS.3] about news-ACC (refute)-PAST.3

'Putin's spokesman refuted the news about the president having gotten married.'

(33c) * / ?? Путин-нің, баспасөз хатшы-сы [президент неке-ге тұр-ван] туралы хабарды жоққа шывар-ды. 20/4 (3 QM) [8/2; 9/0 (3 QM); 3/2]

Putin-GEN press secretary-POSS-3 [president marriage-DAT stand-NF] about news-ACC (refute)PAST.3

'Putin's spokesman refuted the news about the president having gotten married.' 


\section{VI.9. The postposition üšin}

(34а) Байзақ̧ов - [экс-президент Бакиев деген ава-сы-ның қ̧аш-ып кет-кен-і] Ушін жұмыс-тан шызар-ылл-дыл. 20/11 (3 QM) [8/5; 9/4 (3 QM); 3/2]

Bayzaqov [ex-president Bakiev called uncle-POSS.3-GEN flee-CV leave-NF-POSS.3] for workABL release-PASS-PAST. 3

'Baizakov was relieved from office, because his uncle, ex-president Bakiev fled.'

(34b) Байзақ̧ов - [экс-президент Бакиев деген ава-сы-ның қ̧аш-ыл кет-кен-діг-і] үшін жұмыс-тан шызар-ылл-дыл. 20/11 (3 QM; 1 NA) [8/4 (1 NA); 9/4 (3 QM); 3/3]

Bayzaqov [ex-president Bakiev called uncle-POSS.3-GEN flee-CV leave-NF-LIq-POSS.3] for work-ABL release-PASS-PAST. 3

'Baizakov was relieved from office, because his uncle, ex-president Bakiev fled.'

(34c) Байзақ̧ов - [экс-президент Бакиев деген ава-сы құаш-ыл кет-кен] үшін жұмыстан шызар-ылл-дыл. 20/9 (1 QM) [8/5; 9/2 (1 QM); 3/2]

Bayzaqov [ex-president Bakiev called uncle-POSs.3 flee-CV leave-NF] for work-ABL releasePASS-PAST.3

'Baizakov was relieved from office, because his uncle, ex-president Bakiev fled.'

(35а) 112 адам [құжат-сыз ҚР-да тұр-ып жат-қ̧ан-ы]] үшін әкімшілік жауапкершілікке тарт-ыл-дыл. 20/19 [8/7; 9/9; 3/3]

112 person [document-WITHOUT QR-LOC stand-IP LV.CONT-NF-POSS.3] because.of administration charge-DAT pull-PASS-PAST.3

'Against 112 people were pressed legal charges, because they were staying in the Republic of Kazakhstan without any documents.' 
(35b) 112 адам [құжат-сыз ҚР-да тұр-ып жат-қ̧ан-дыв-ыл] үшін әкімшілік жауапкершілік-ке тарт-ьлл-ды. 20/17 [8/6; 9/8; 3/3]

112 person [document-WITHOUT QR-LOC stand-IP LV.CONT-NF-LIq-POSS.3] because.of administration charge-DAT pull-PASS-PAST.3

'Against 112 people were pressed legal charges, because they were staying in the Republic of Kazakhstan without any documents.'

(35c) \% 112 адам [құжат-сыз ҚР-да тұр-ыл жат-ққан] үшін әкімшілік жауапкершілікке тарт-ылл-ды. 20/12 [8/5; 9/4; 3/3]

112 person [document-WITHOUT QR-LOC stand-IP LV.CONT-NF] because.of administration charge-DAT pull-PASS-PAST.3

'Against 112 people were pressed legal charges, because they were staying in the Republic of Kazakhstan without any documents.'

\section{VII. -(A)r-headed complement clause of the postposition -ABL burïn}

(36а) * [Осы оқива бол-мас-ьл]нан бұрын Г.Каримова әке-сі-мен хабарлас-ыл, Израиль-ге емдел-у-ге жібер-у-ін сұра-птыл. 20/5 [8/1; 9/4; 3/0]

[this event be-NEG.NF-POSS.3]ABL before G.Karimova father-POSS.3-INST communicate-CV Israel-DAT recover-NNF-DAT send-NNF-POSS.3.ACC ask-EVID.3

Intended: 'Before this event, G. Karimova was in touch with her father and requested to be sent to Israel to recover.'

\section{Relative clauses}

(37а) Жігіт [молда-ның дала-ва тық-қан] қ̧ойма-сын хан-ва тау-ылn бер-ді. 20/16 (1 QM; 1 NA) [8/6 (1 NA); 9/7 (1 QM); 3/3]

young.man [mullah-GEN steppe-DAT hide-NF] treasury-POSS.3.ACC khan-DAT find-IP LV.BPAST.3

'The young man revealed to the khan the treasury that the mullah had hidden in the steppe./ The young man revealed to the khan the mullah's treasury hidden in the steppe.' 
(37b) *Жізіт [молда-ның дала-zа тыққ-қ̧ан-дық] қ̧ойма-сын хан-ва тау-ыл бер-ді. 20/1 $[8 / 0 ; 9 / 0 ; 3 / 1]$

young.man [mullah-GEN steppe-DAT hide-NF-LIq] treasury-POSS.3.ACC khan-DAT find-IP LV.B-PAST. 3

Intended: 'The young man revealed to the khan the treasury that the mullah had hidden in the steppe.'

(37c) *Жігіт [молда дала-ва тыққ-қ̧ан-дық] қ̧ойма-сын хан-ва тау-ып бер-ді. 20/1 [8/0; $9 / 0 ; 3 / 1]$

young.man [mullah steppe-DAT hide-NF-LIq] treasury-POSs.3.ACC khan-DAT find-IP LV.BPAST. 3

Intended: 'The young man revealed to the khan the treasury that the mullah had hidden in the steppe.

(38а) [Әнъгіме жалпақ ел-дің жай-ына көш-кен] кез-де, Абай шеш-іл-е түс-ті. 20/16 (1 NA) $[8 / 7 ; 9 / 7$ (1 NA); 3/2]

[story broad people-GEN place-POSS.3.DAT travel-NF] time-LOC Abay open-PASS-A LV-PAST.3

'At the time when the story spread among all of the people, Abai started to evolve.'

(38b) *[Әңзгіме жалпақ ел-дің жай-ына көш-кен-дік] кез-де, Абай шеш-іл-е түс-ті. 20/2 (1 NA) [8/0; 9/2; 2/0 (1 NA)]

[story broad people-GEN place-POSS.3.DAT travel-NF-LIq] time-LOC Abay open-PASS-A LVPAST. 3

Intended: 'At the time when the story spread among all of the people, Abai started to evolve.'

(39а) [Әке-м-нің арманда-ван] бір той-ы өт-ті. 20/16 [8/5; 9/8; 3/3]

[father-POSS.SG1-GEN dream-NF] one celebration-POSS.3 pass-PAST.3

'It was such a celebration that my father had dreamt of.'

(39b) *[Әке-м-нің арманда-ван-дыз-ьl] бір той өт-ті. 20/0 [8/0; 9/0; 3/0]

[father-POSS.SG1-GEN dream-NF-LIq-POSS.3] one celebration-POSS.3 pass-PAST.3

Intended: 'It was such a celebration that my father had dreamt of.' 
(39с) *[Әке-м арманда-ган-дық] бір той өт-ті. 20/0 [8/0; 9/0; 3/0]

[father-POSS.SG1 dream-NF-LIq] one celebration-POSS.3 pass-PAST.3

Intended: 'It was such a celebration that my father had dreamt of.' 


\section{Original Questionnaire 2}

Төмендегі сөйлемдердің барлығы бірбірінен басқаша, бірақ кейбір сөйлемдер арасында айырмашылық өте аз.

Дұрыс сөйлемдердің жанына +, ал қате сөйлемдердің жанына -, ал күмәнданған кезде ? белгілерін қоюларыңызды өтінемін.

1. Әңгіме жалпақ елдің жайына көшкен кезде, Абай шешіле түсті.

2. Оқастың келгенінен соң клуб ісі жанданды.

3. Оқас келгеннен соң клуб ісі жанданды.

4. Ал азан шақыру арқылы сәбиге ат қою дәстүрі қазақ жеріне исламның келуімен тығыз байланысты.

5. Еркектерге әйелдің иіссу шашқаны ұнай ма?

6. Жігіт молданың далаға тыққан қоймасын ханға тауып берді.

7. Салтанатты қол қою рәсімінен кейін 18 мамырда Күлтегін күні аталып өтетіні белгіленді.

8. Ата-анам филолог болғандықтан бала кезден тілге икемім жақсы болды.

9. Оқастың келгендігі соң клуб ісі жанданды.

10. Мен айтуға рұқсат етіңізші.

11. Байзақов - экс-президент Бакиев деген ағасының қашып кеткені үшін жұмыстан шығарылды.

12. Оқас келген соң клуб ісі жанданды.

13. Әкемнің негізгі тамыры ақтөбелік болғандығымен, туған жері Қарақалпақстан.

14. Хабарламада атап көрсетілгендігіндей, Юрий Берг шешімге қол қойған.

15. Әкем армандағандық бір той өтті.

16. Өмірбек өткен аптада Алматыда болғандығын айтты. 
17. Путиннің баспасөз хатшысы президенттің некеге тұрғаны туралы хабарды жоққа шығарды.

18. Жұмысты мойындамағандығы, жұмысты көңілденіп істемегендігі ісінен де көрініп тұр.

19. Ата-анам филолог болғандығынан бала кезден тілге икемім жақсы болды.

20. Суық түсуімен бірге маусымдық аурулар да пайда болады.

21. Хабарламада атап көрсетілгеніндей, Юрий Берг шешімге қол қойған.

22. Алла елшісінің істегеніндей істе.

23. Байзақов - экс-президент Бакиев деген ағасының қашып кеткендігі үшін жұмыстан шығарылды.

24. Менің даңғыра соққанымда, қырық есікті бекітіп тастаңдар.

25. Тауға барғанымды, коньки тепкенімді жақсы көремін.

26. Бастығымыз үнсіз қалды - онысы Мусяның айтқанына амалсыз көнгенінің белгісі.

27. Оқастың келгендігінен соң клуб ісі жанданды.

28. Қазіргі күнге дейін әкем туралы мәліметтер халыққа жеткенге куанамын.

29. Мейрамхана жуырда ашылу күтілуде.

30. Мейрамхананың жуырда ашылуы күтілуде.

31. Үйдің ертеде салынғанына көз жеткізу де оңай.

32. Әкемнің армандағандығы бір той өтті.

33. Суық түсумен бірге маусымдық аурулар да пайда болады.

34. Ал азан шақыру арқылы сәбиге ат қою дәстүрі қазақ жеріне ислам келумен тығыз байланысты.

35. Алғашқы кеңес кезінде, дәрігер - әйелдің жалпы денсаулығының қандай болғандығы туралы анықтайды. 
36. Оның табыт алатыны күмәнсіз.

37. Ғайшаның келгеніне шейін, бізді Садық мұғалім оқытты.

38. Әшімнің баяндама жасағаны сайын, жұрт көп келеді.

39. Журнал тағдыры не болатынды алдағы уақыт көрсетер.

40. Әшім баяндама жасаған сайын, жұрт көп келеді.

41. Тауға барғанды, коньки тепкенді жақсы көремін.

42. Өмірге басқа көзқараспен қарауымды үйреніп жүрмін.

43. Әшімнің баяндама жасағандығы сайын, жұрт көп келеді.

44. Осы оқиға болмасынан бұрын Г.Каримова әкесімен хабарласып, Израильге емделуге жіберуін сұрапты.

45. Спорт киімі қолайлы, жеңіл және әдемі болумен бірге, оның үстіне дененің температурасын реттеп те отыра алатын болуға тиіс.

46. Енем немересін қасына жіберуімді өтінеді.

47. Оның табыт алатындығы күмәнсіз.

48. Әңгіме жалпақ елдің жайына көшкендік кезде, Абай шешіле түсті.

49. 112 адам құжатсыз ҚР-да тұрып жатқаны үшін әкімшілік жауапкершілікке тартылды.

50. Әшім баяндама жасағаны сайын, жұрт көп келеді.

51. Путиннің баспасөз хатшысы президент некеге тұрған туралы хабарды жоққа шығарды.

52. Даңғыра соққандығымда, қырық есікті бекітіп тастаңдар.

53. Қазіргі күнге дейін әкем туралы мәліметтердің халыққа жеткеніне қуанамын.

54. Ғайша келгенге шейін, бізді Садық мұғалім оқытты.

55. Әкемнің негізгі тамыры ақтөбелік болғанымен, туған жері Қарақалпақстан. 56. Алла елшісінің істегендігіндей істе. 
57. Жігіт молданың далаға тыққандық қоймасын ханға тауып берді.

58. Айтуыма рұқсат етіңізші.

59. Жігіт молда далаға тыққандық қоймасын ханға тауып берді.

60. Журналдың тағдыры не болатынын алдағы уақыт көрсетер.

61. Ең жақсы қасиеті - ешкіммен төбелесіп, сөзге келмейтіні еді.

62. Алғашқы кеңес кезінде дәрігер әйелдің жалпы денсаулығының қандай болғаны туралы анықтайды.

63. Алла елшісі істегендей істе.

64. Салтанатты қол қою рәсімінен кейін 18 мамырда «Күлтегін күні» аталып өтетіндігі белгіленді.

65. Тауға барғанымды, коньки тепкенімді жақсы көремін.

66. Алғашқы кеңес кезінде дәрігер әйелдің жалпы денсаулығы қандай болған туралы анықтайды.

67. Арыстан - басқару мен басты рөлде жүргенін ұнатады.

68. Суықтың түсуімен бірге маусымдық аурулар да пайда болады.

69. Үйдің ертеде салынғандығына көз жеткізу де оңай.

70. 112 адам құжатсыз ҚР-да тұрып жатқандығы үшін әкімшілік жауапкершілікке тартылды.

71. Өмірбек өткен аптада Алматыда болғанын айтты.

72. Әкем негізгі тамыры ақтөбелік болғанмен, туған жері Қарақалпақстан.

73. Сәнді киінуімді өте жақсы көремін.

74. Әкемнің армандаған бір тойы өтті.

75. Бастығымыз үнсіз қалды - онысы Мусяның айтқанына амалсыз көнгендігінің белгісі.

76. Еркектерге әйелдің иіссу шашқандығы ұнай ма? 
77. Жұмысты мойындамағаны, жұмысты көңілденіп істемегені ісінен де көрініп тұр.

78. Оның тамақтануы үшін әйелі көмектеседі.

79. Тауға барғандықты, коньки теркендікті жақсы көремін.

80. Шешесі ерте қайтыс болғандықтан, менің анам Әлишаны да Тыныбала апа бағып-қағып өсірген.

81. Оқастың келгені соң клуб ісі жанданды.

82. Путиннің баспасөз хатшысы президенттің некеге тұрғандығы туралы хабарды жоққа шығарды.

83. Спорт киімінің қолайлы, жеңіл және әдемі болуымен бірге, оның үстіне дененің температурасын реттеп те отыра алатыны болуға тиіс.

84. Өмірге басқа көзқараспен қарауды үйреніп жүрмін.

85. Мен даңғыра соққанымда, қырық есікті бекітіп тастаңдар.

86. Шешесінің ерте қайтыс болғандығынан, менің анам Әлишаны да Тыныбала апа бағып-қағып өсірген.

87. Ең жақсы қасиеті - ешкіммен төбелесіп, сөзге келмейтіндігі еді.

88. Ол тамақтану үшін әйелі көмектеседі.

89. Бүркіт ақша санауын біледі.

90. Бүркіт ақша санауды біледі.

91. 112 адам құжатсыз ҚР-да тұрып жатқан үшін әкімшілік жауапкершілікке тартылды.

92. Байзақов - экс-президент Бакиев деген ағасы қашып кеткен үшін жұмыстан шығарылды.

93. Сәнді киінуді өте жақсы көремін.

94. Енем мен немересін қасына жіберуді өтінеді.

95. Арыстан - басқару мен басты рөлде жүргенді ұнатады. 
96. Мен даңғыра соққанда, қырық есікті бекітіп тастаңдар.

97. Ғайшаның келгендігіне шейін, бізді Садық мұғалім оқытты. 